\title{
MECHANISM-BASED DESIGN OF BIOACTIVE CYCLOPROPANATED SUGARS
}

\author{
Dylan Davies
}

\begin{abstract}
A thesis submitted to Victoria University of Wellington
In parital fulfilment of the

requirements for the degree of

Masters of Biomedical Science
\end{abstract}

Victoria university of Wellington

2013

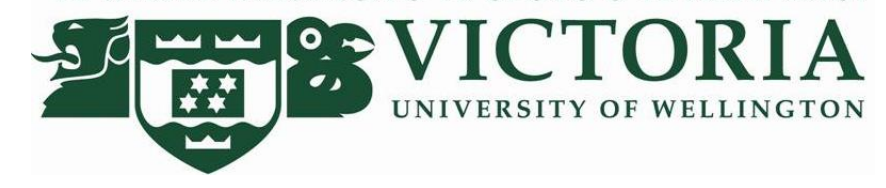




\section{Abstract}

Carbohydrates are important feed stocks in synthesis of natural products and so attract the interest of many organic researchers throughout the world, most notably in the last 10 years. The work described within explores the manipulation of the glucose-derived glucal. The addition of a reactive substituted cyclopropane across the alkene has been employed synthetically for many years, the subsequent ring breaking/expansion has been identified in the lab as slow and needing the support of catalysts. We ask the question, "Will cyclopropanated carbohydrates undergo the slow ring breaking/expansion in the presence of proteins, and are we able to identify which of the two types of mechanisms the reaction is going through?" The cyclopropane will act as a warhead to bind to proteins through Ferrier like rearrangements, resulting in irreversible inhibition. To identify the potential of such compounds, a combination of techniques are used to identify potential pathways, protein targets and reactivity through structure activity relationships.

The key steps involved in finding out the potential of cyclopropanated carbohydrates are to determine biological activities through bio-assays, structure activity relationships, selective binding, chemical genetics and chemical proteomics. The bio-assays together with structure activity relationships provides evidence on which chemical mechanism is occurring when the biological target is interacting with the bioactive cyclopropanated carbohydrates. The most active compound, benzose (7), was subjected to chemical genetic analysis to determine the pathways and processes that are involved with the mode of action. The chemical genetic analysis was complimented by chemical proteomics to identify the direct biological target. Analogues of benzose were synthesised by the addition of azide groups to undergo a Huisgen Cyclisation within a cell lysate to facilitate binding to an alkyne-substituted matrix. 


\section{Acknowledgments}

I would like to begin by thanking my family Wendy, John, Rhys and Casey and Tom Morley without whose support mentally, emotionally and financially, I would have never survived to reach the end of my project.

My biggest thanks is directed to my primary supervisor Dr Paul TeesdaleSpittle. I know I was classed as a unique student, but Paul was able to put up with my short attention span and cheeky nature with ease. "Dylan is my favourite student to make fun of" Paul Teesdale-spittle. My "secondary" supervisor Dr Joanne Harvey was a fantastic help in every aspect of Organic Synthetic Chemistry, from giving me space in her lab to making me jump half a metre with fright.

To my lab mates Jing Jing Wang "no one loves you (Dylan) because you are too skinny", Hemi Cumming, Thomas Bevan, Kalpani Somarathne, Scott Riordan The Punk, Stephan Tat, Sam Ting, Mark Barlett and Claire "bestest best friend" Turner, thank you so much for helping me over the last 2.5 years, thanks to all those who joined in on the random dance parties in the lab.

A special thanks to Peter Moore, thank you for taking me under your wing and teaching me almost everything you know about carbohydrate cyclopropanes (I'm still winning).

To the chemical genetics lab, thank you for letting a chemist feel welcome, especially my Wellington best friend Christina Roberts, Ah yeah bro, thanks aye, yeah nah you were all good.

My writing buddy Sarrabeth Stone, "jiggle jiggle" haha brilliant! You are awesome and thanks for having dinner with me all those times, and thank you for telling me off when my attention drifted away from my thesis. 


\section{TABLE OF CONTENTS}

MECHANISM-BASED DESIGN OF BIOACTIVE CYCLOPROPANATED SUGARS .. $\boldsymbol{i}$

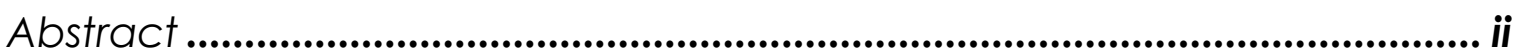

Acknowledgments ................................................................................................ iii

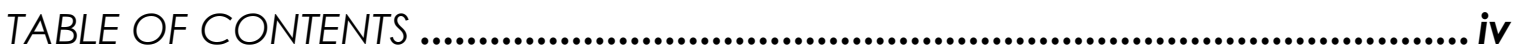

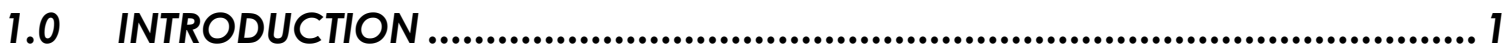

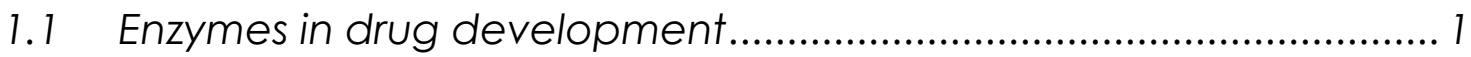

1.2 Approaches to drug design and discovery:................................... 4

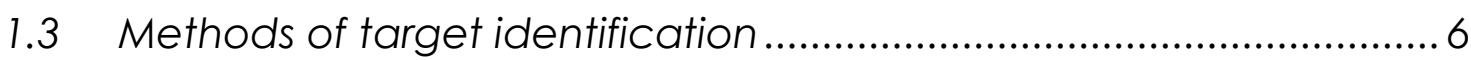

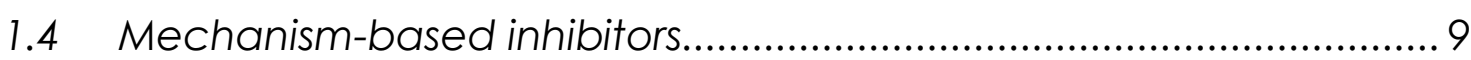

1.4.1 Cyclopropanated compounds .................................................... 11

1.4.2 Carbohydrate-cyclopropanes ................................................. 14

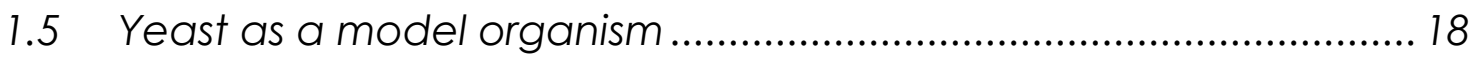

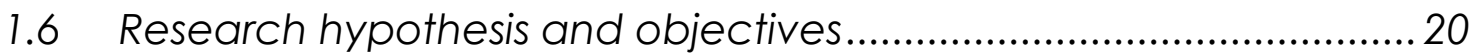

1) Prepare a range of cyclopropanated compounds ...........................2 20

2) SAR analysis to determine the most active compound against $S$.

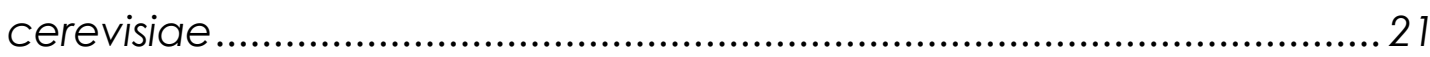

3) Identify potential pathways of interactions by chemical genomics 21

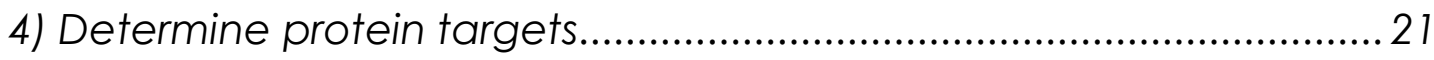

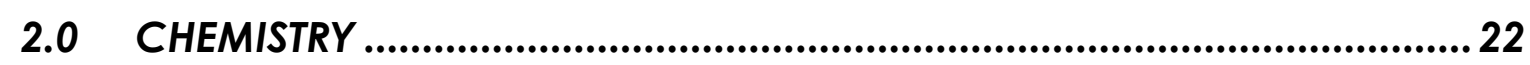

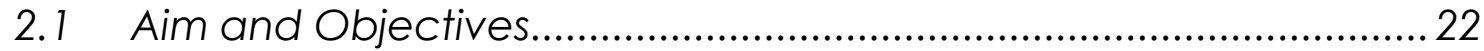

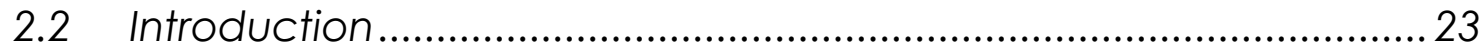

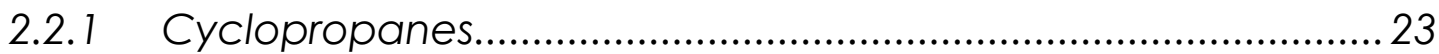




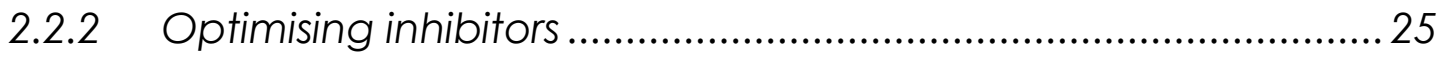

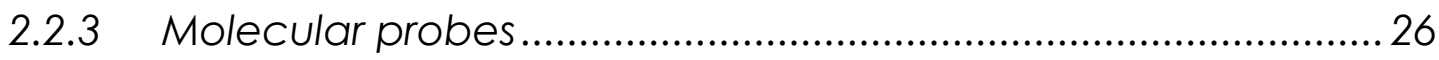

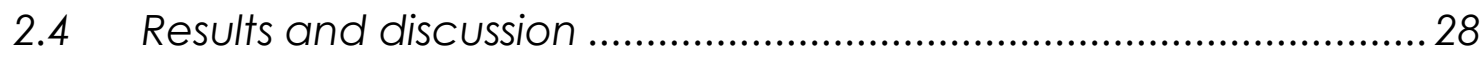

2.4.1 Synthesis of cyclopropanated carbohydrates derivatives 4 to

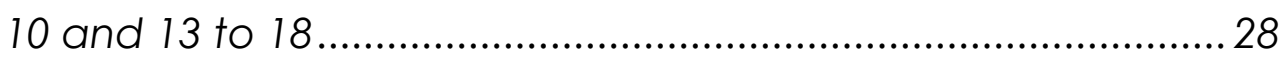

2.4.2 Synthesis of cyclopropanated carbohydrate derivatives 29 to 33 34

2.4.3 Synthesis of cyclopropanated carbohydrate derivatives 25,26 , 27 and 31 36

2.4.4 Synthesis of cyclopropanated carbohydrate derivative $12 \ldots . .37$

2.4.5 Synthesis of cyclopropanated carbohydrate derivative $11 \ldots .38$

2.4.6 Synthesis of compounds 36, 38 and 37; exploration of probe attachment.

2.4.7 Synthesis of cyclopropanated carbohydrate derivative 24; the probe linker.....

2.4.8 Synthesis of Alkyne-substituted matrix; the probe. 44

2.6 Experimental 45

3.0 BIOLOGY

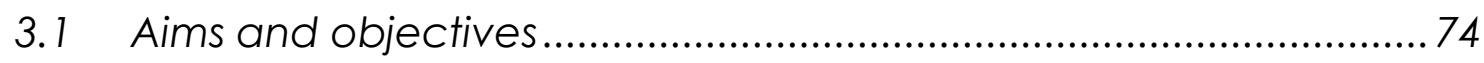

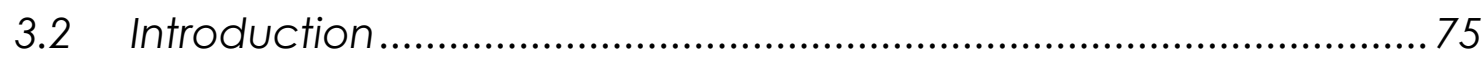

3.2.1 Structure Activity Relationship.................................................... 75

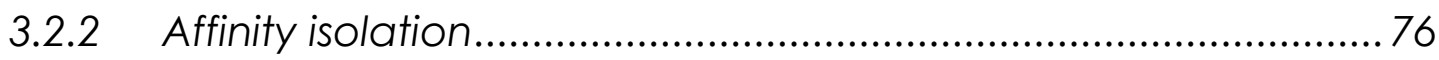

3.2.3 Yeast gene deletion sets (Saccharomyces cerevisiae) ............. 77

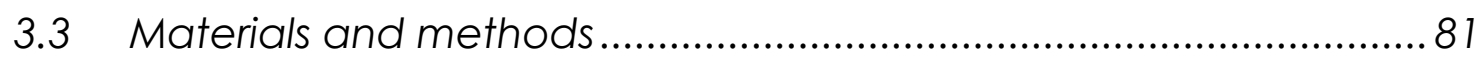

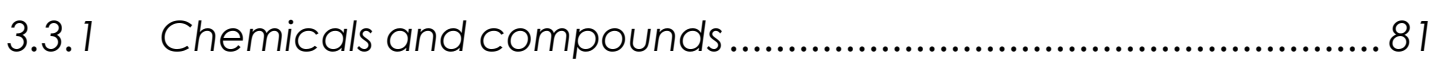




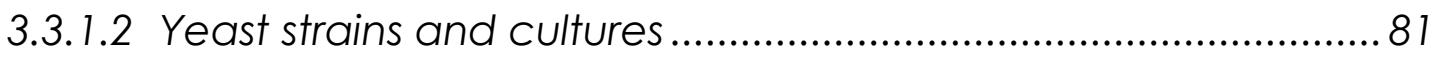

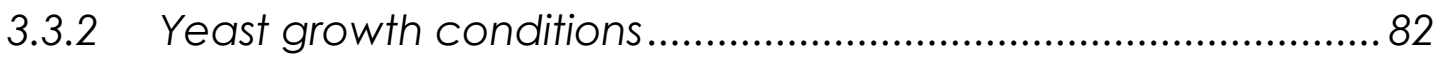

3.3.3 Initial IC 50 assay in Saccharomyces cerevisiae ...........................83

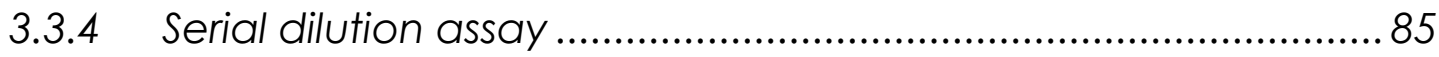

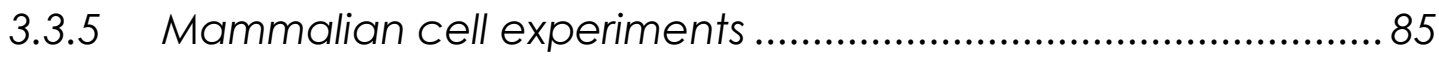

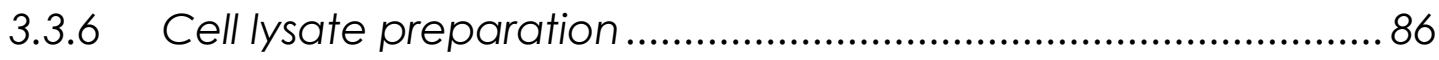

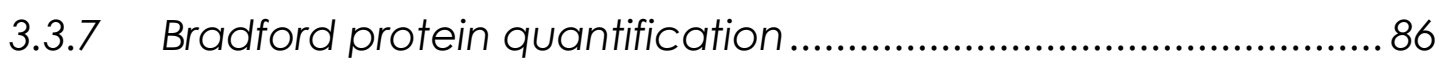

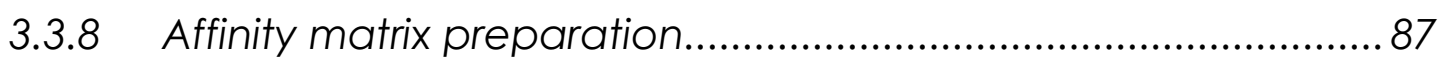

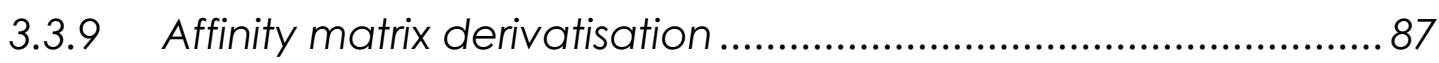

3.3.10 Huisgen Cyclisation of 24 to the alkyne-substituted sepharose

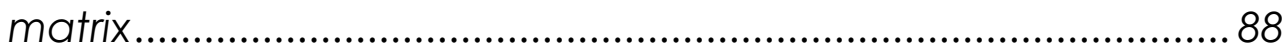

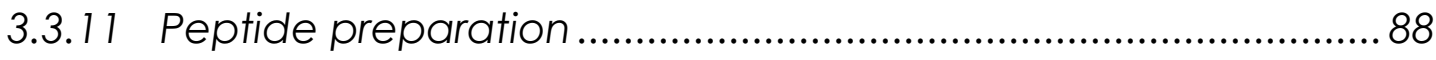

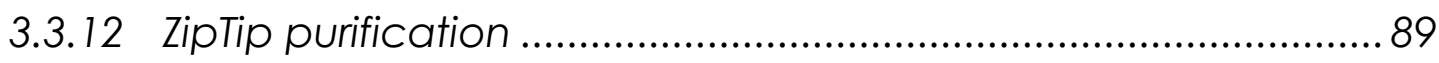

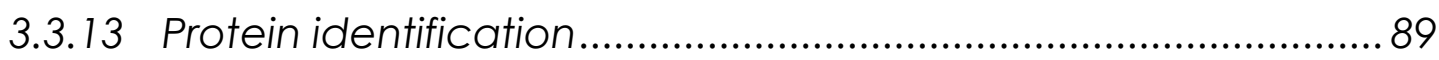

3.3.15 Validation of benzose breakdown in agar ............................... 91

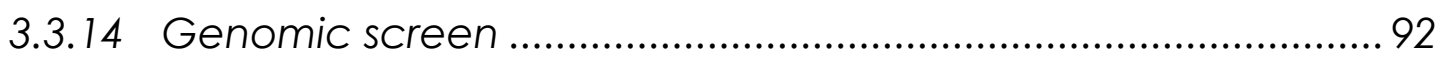

3.3.16 Validation of the genomic screen .............................................. 93

3.3.17 Unfolded protein response element (UPRE) assay..................... 94

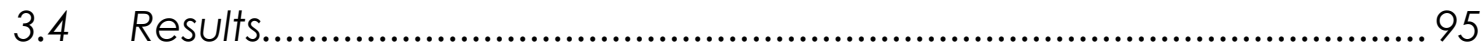

3.4. 1 Benzose is active in $\Delta p d r 1 \Delta p d r 3$ dual knockout S. cerevisiae.. 95

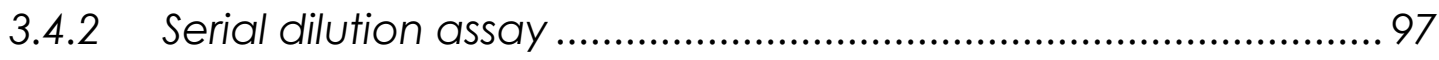

3.4.3 Identification of the lead compound through SAR analysis..... 98

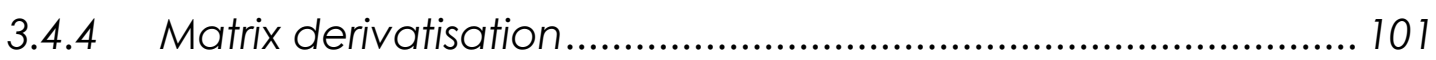

3.4.5 Chemical proteomic analysis .................................................. 102

3.4.6 Benzose breaks done in agar ................................................. 103

3.4.7 Chemical genomic Assay ........................................................ 104

3.4.8 Validation of high throughput results ....................................... 110 
3.4.9 Benzose has no effect on the unfolded protein response...... 113

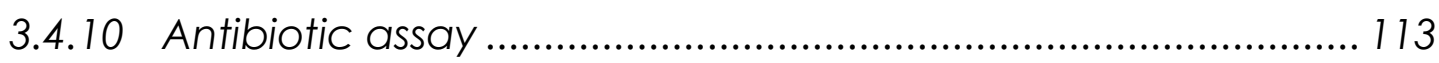

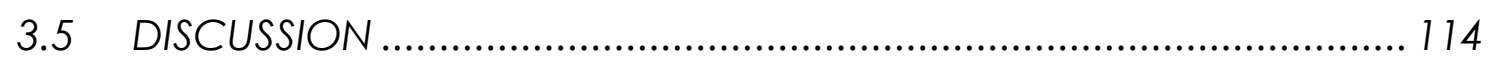

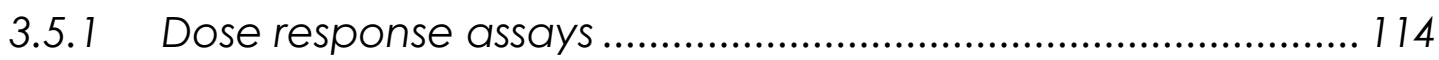

3.5.2 Structure activity relationship of cyclopropanated

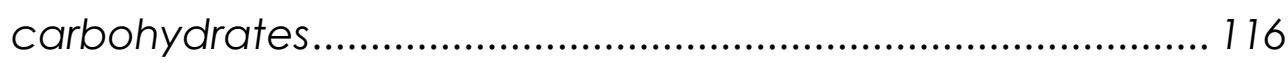

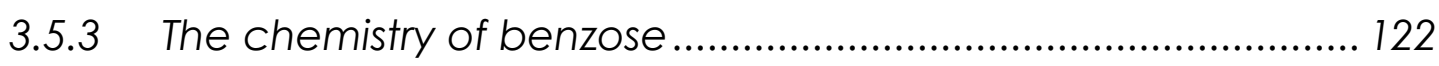

3.5.4 Alkyne-substituted sepharose matrix....................................... 125

3.5.5 Chemical genomic screen gives insight to the biological role of

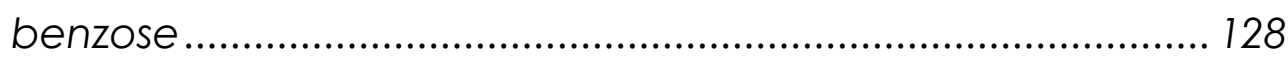

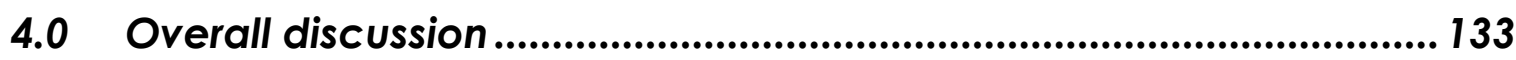

4.1 Assessment of experimental strategies and protocols ................. 133

4.2 Assessment of the aims and objectives ..................................... 135

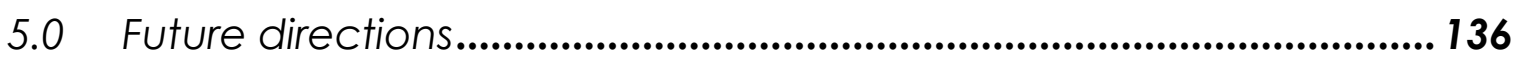

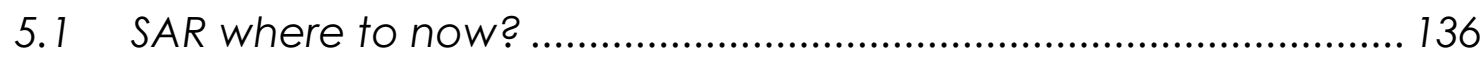

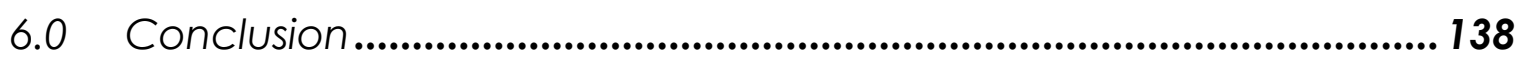

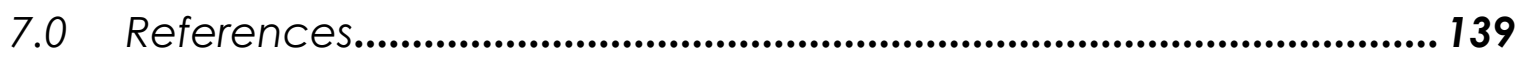

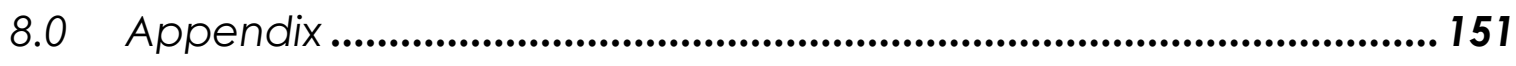




\section{Abbreviation list}

IH NMR Proton nuclear magnetic resonance

${ }^{13} \mathrm{C}$ NMR Carbon nuclear magnetic resonance

$\delta \quad$ Chemical Shift (ppm)

ABC ATP-binding cassette

$\mathrm{Ac}_{2} \mathrm{O} \quad$ Acetic anhydride

Ally $\quad \mathrm{CH}_{2} \mathrm{CHCH}_{2}-$

AIBN Azobisisobutyronitrile

Bn Benzyl

Bz Benzoyl

bs Broad singlet

b.p. $\quad$ Boiling point

$\mathrm{CDCl}_{3} \quad$ Deuterated chloroform

CHCA alpha-Cyano-4-hydroxycinnamic acid

ClonNAT Nourseothricin

Conc. Concentration or concentrated

COSY Correlation spectroscopy

d Doublet

dd $\quad$ Doublet of doublets

ddd Doublet of doublets of doublets

$\mathrm{dd}_{2} \mathrm{O} \quad$ Double distilled water

DCM Dichloromethane 
DMF N,N-dimethylformamide

DMSO Dimethylsulfoxide

DTT Dithiothreitol

EDTA Ethylenediaminetetraacetic acid

G418 Geneticin

GFP Green fluorescent protein

GO Gene Ontology

eq. Equivalents

$\mathrm{Et}_{3} \mathrm{~N} \quad$ Triethylamine

$\mathrm{Et}_{2} \mathrm{O} \quad$ Diethylether

EłOAc Ethyl acetate

HMBC Heteronuclear multi bond correlation

IR Infrared

IUPAC International union of pure and applied chemistry

LDA Lithium diisopropylamide

m.p. Melting point

MDR Multi-drug resistance

NBS $\quad \mathrm{N}$-bromosuccinimide

NMR Nuclear magnetic resonance

NOESY Nuclear Overhauser effect spectroscopy

Nu Nucleophile

OD Optical density 


$\begin{array}{ll}\text { PDR } & \text { Pleiotropic drug resistance } \\ \text { ppm } & \text { Parts per million } \\ q & \text { Quartet } \\ \text { r.t. } & \text { Room temperature } \\ \text { Rf } & \text { Retention factor } \\ \text { s } & \text { Singlet } \\ \text { sat. } & \text { Saturated } \\ \text { SC } & \text { Synthetic } \\ \text { SD } & \text { Synthetic dropout media }\end{array}$

SGA Synthetic genetic array

$\dagger \quad$ Triplet

TEBAC Benzyltriethylammonium chloride

TFA Trifluoroacetic acid

THF Tetrahydrofuran

TLC Thin layer chromatography

$\operatorname{Tr} \quad$ Trityl

UPR Unfolded protein response

UPRE UPR element

wt Wild-type

$x x x \Delta \quad$ Deletion from the DMA

YGDS Yeast genome deletion set

YPD Yeast extract peptone dextrose media 


\subsection{INTRODUCTION}

We introduce here the background to cyclopropanes and carbohydrates and how these can be utilised in the field of drug development.

This introduction shows the importance of enzymes in drug development, and how this information can be used in designing drugs to prevent or alleviate health related diseases. A method in drug development is introduced that has not been used to the potential we believe it presents. Finally, the use of yeast as a model organism in identifying potential pathways and processes that bioactive compounds target is presented, along with the use of yeast in identifying potential lead drugs for further optimisation.

\subsection{Enzymes in drug development}

Enzymes are crucial for existence of all forms of life. Without the ability to catalyse reactions, life would not exist (Szostak et al. 2001). These biological catalysts have evolved to exhibit a high degree of specificity and catalyse reactions with highly conserved mechanisms. Enzymes have been a point of focus for drug development, due to their role in metabolic pathways and potential for manipulation in diseases that involve abnormal protein expression (Neurath \& Walsh, 1976; Marik et al. 2011).

Drugs that inhibit over-expressed proteins are used to decrease, delay or prevent the progression of the related disease (Arnoldo, 2008). For example, a large area of cancer research is focused on designing novel anticancer drugs that are based on the normal substrate of enzymes. These enzymes are normally highly expressed in cancerous cells (Shah et al. 2004), and it has been shown that inhibiting these proteins can cause a decrease in cancerous growth (Marik et al. 2011). To be therapeutically 
useful, an inhibitor must suppress the activity of a protein that is essential for disease progression, with limited adverse effects (Dombernowsky et al. 1998; Semenza, 2002). A well designed inhibitor typically has a $K_{d}$ value in the nanomolar (nM) range (Friedman et al. 1993).

Common practise in drug development is to identify a protein target that is over-expressed in a related health problem. For example, up regulation of the HER-mediated signalling network has been implicated in breast cancer, resulting from the amplification of the HER-2 gene (Slamon et al. 1987). HER-2 has been found to have a specific activity of $11 \mathrm{nmol} / \mathrm{min} /$ $\mathrm{mg}$ and protein over-expression is present in approximately $20 \%$ of human breast cancers and is associated with decreased survival (Slamon et al. 1989). A successful strategy to decease the effect of overexpressed HER-2 protein involved the development of inhibitors that decrease the HER-2 signalling pathways which play a role in the cancer cell proliferation. The extracellular binding domain F of HER-2 by trastuzumab, a humanized monoclonal antibody, has been shown to decrease cell proliferation (Vogel et al. 2002; Cameron et al. 2008). HER-2 is also targeted by the small-molecule inhibitor Lapatinib, the structure is shown in figure 1.1 (Cameron et al. 2008).

Enzymes can be targeted in not just humans. Bacterial related health

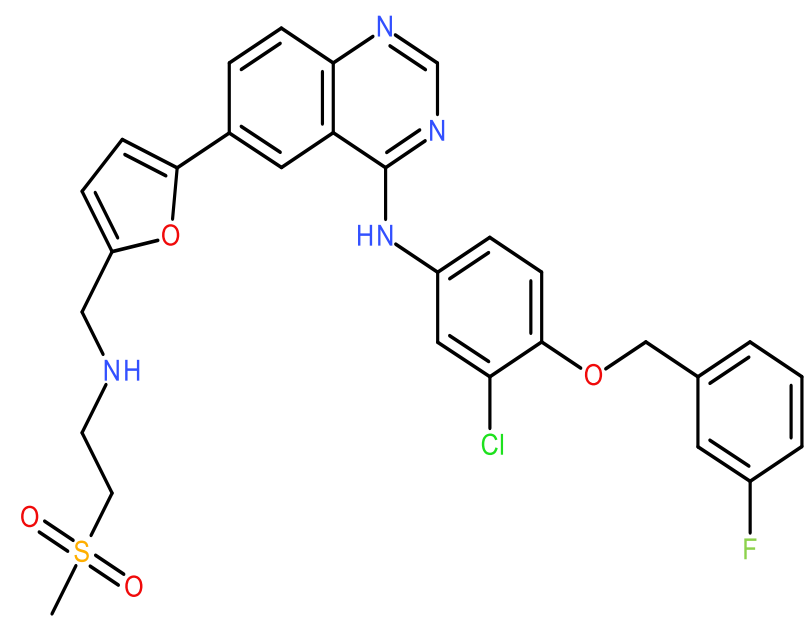

Figure 1.1. Lapatinib a bioactive small molecule inhibitor of HER-2. 
problems are also being researched to develop new methods of inhibiting enzymes associated with antibiotic resistant infections.

Antibiotic-resistant infections have become a major challenge for healthcare professionals (Neidell et al. 2012). More die as a result from methicillin-resistant Staphylococcus aureus (MRSA) (approximately 19,000 a year) than complications assocaited AIDS in USA (Klevens et al. 2008). To overcome drug resistance, a new drug target or new drug classes are needed. Multiple approaches will then increase the rate of the discovery of new target proteins to combat antibiotic-resistant infections (Smith, 2005; Lizawa et al. 2004; Van Bambeke et al. 2008). One unexploited target in antibacterial drug design is present in the de novo purine biosynthetic pathway, 5-(carboxylamino)imidazole ribonucleotide synthase (CAIR-synthase). This pathway is a useful antibacterial target as it is different to that of humans (Firestine et al. 2009; Thoden et al. 2008). This gives an important potential target for an enzyme inhibiting drug and demonstrates the importance of designing single target inhibitors for drug discovery. The next step of finding bioactive compounds that can selectively inhibit CAIR-synthase can be achieved by synthesising a compound (based on the pre-existing knowledge of the CAIR-synthase active site) or testing a library of compounds against the protein. Firestine et al. (2009) tested 48000 drug-like compounds against CAIR-synthase at inhibitor concentrations between 5- $27 \mu \mathrm{M}$ and initially found 212 potential inhibitors. Of these 14 showed dose-response relationships. Thoden et al. (2008) were also the first research group to find selective, non-nucleotide inhibitors for CAIR-synthase.

In order to achieve advances in drug design and identification of bioactive compounds it is vital to adopt multiple approaches (Balani et al. 2005). 


\subsection{Approaches to drug design and discovery:}

Drug design has been approached from many angles and each angle has its advantages and disadvantages (Patani \& LaVoie, 1996; Wolber et al. 2008). The approaches to drug design can be broken down to three common methods.

1) Ligand-Based Drug Design

Designing a compound that interacts with a target, based on knowledge of existing ligands that interact with the target site. Typically this approach uses quantitative structure activity relationship (QSAR) analysis and requires activity profiles of many ligands (Yang \& Huang, 2006). It is especially valuable when high quality target site information is sparse, as can often be the case with membrane-associated target proteins.

2) High Throughput Screening

Discovery of a lead compound, typically from natural products or libraries of combinatorially synthesised compounds. For example the Maybridge, ChemDic, Chembridge and MS Spectrum Libraries consisting of over $49,000+$ drug like compounds, are commercially available libraries that can be used for high throughput screens. Depending on the screening methodology adopted, this approach does not require any prior knowledge of either target or drug-target interactions. The library screens can then be spilt up into three types:

1) Structure based screens;

2) Activity based screens; and

3) High throughput libraries screens.

Once a lead compound is discovered, it will then be optimised through medicinal chemistry (Costantino \& Barlocco, 2006; Kolb \& Sharpless, 2003) and/or QSAR approaches as described above. 
3) Target-Based Drug Design

Designing a compound that interacts with a target, based on existing knowledge of the target's active site (Ricci et al. 2005; Skulnick et al. 1995). Typically this approach is used for the design of mechanism-based drugs.

The three methods of drug discovery are different, however, all drug development approaches follow a similar path:

1. Synthesis, extraction or compound library;

2. screening against a cell line/target to find activity;

3. identification of targets or interactions if unknown; and

4. optimisation.

A fourth method will be presented and discussed in this thesis. This method is based around well-known organic mechanisms and how they could be catalysed by enzymes. In most cases the approach to drug design is completed against a biological target, ie a protein of interest. However, when the target is unknown, it is essential to identify what the bioactive compound is interacting with. 


\subsection{Methods of target identification}

One of the most important steps in drug development is the identification of the protein target of the bioactive molecule (Phillip, 2002). Knowledge of the interaction between the protein target and the bioactive molecule is essential for understanding the mechanism of the bioactive molecule within a cell (Cho \& Kwon, 2012).

A classical method of target identifying is genetic based, involving mutations introduced into living cells (James et al. 1996). The introduced mutations can include knockout genes or over-expression of certain proteins. When this is done on a large scale with multiple permutations it is referred to as a genomic library (James et al. 1996). A genomic library screened against a drug-like compound will identify resistant or sensitive strains, where particular genes that are knocked out or up-regulated may play a pivotal role in the mechanism of action of the drug-like compound. For example, a deletion library in Saccharomyces cerevisiae treated with rapamycin was able to identify resistant and sensitive strains (Xie et al. 2005). This information was then used to identify that the TOR (target of rapamycin) pathways were being affected. Further studies identified that rapamycin inhibits downstream signalling from the target TOR proteins inhibiting protein synthesis. Chemical genomics together with other approaches of identification can be used to generate strong evidence towards identifying a bioactive compound's target and function (Huang et al. 2004). 
A direct approach for drug target identification involves proteomic profiling, which identifies proteins by peptides. Identification of a target can be completed in forward or reverse chemical proteomic methods, both of which can utilise affinity based interactions (Kramer \& Cohen, 2004). Forward chemical proteomics involves the identification of the target protein of a newly-discovered bioactive molecule (Lokey, 2003). The compound of interest is attached to a resin, then a cell lysate or protein mixture is washed past the resin (affinity pull-down) as shown in figure 1.2. The proteins are then removed by washing or tryptic digest (Bantscheff et al. 2012). The interacting targets can then be identified by mass spectrometry (von Rechenberg et al. 2005; Cho \& Kwon, 2012).

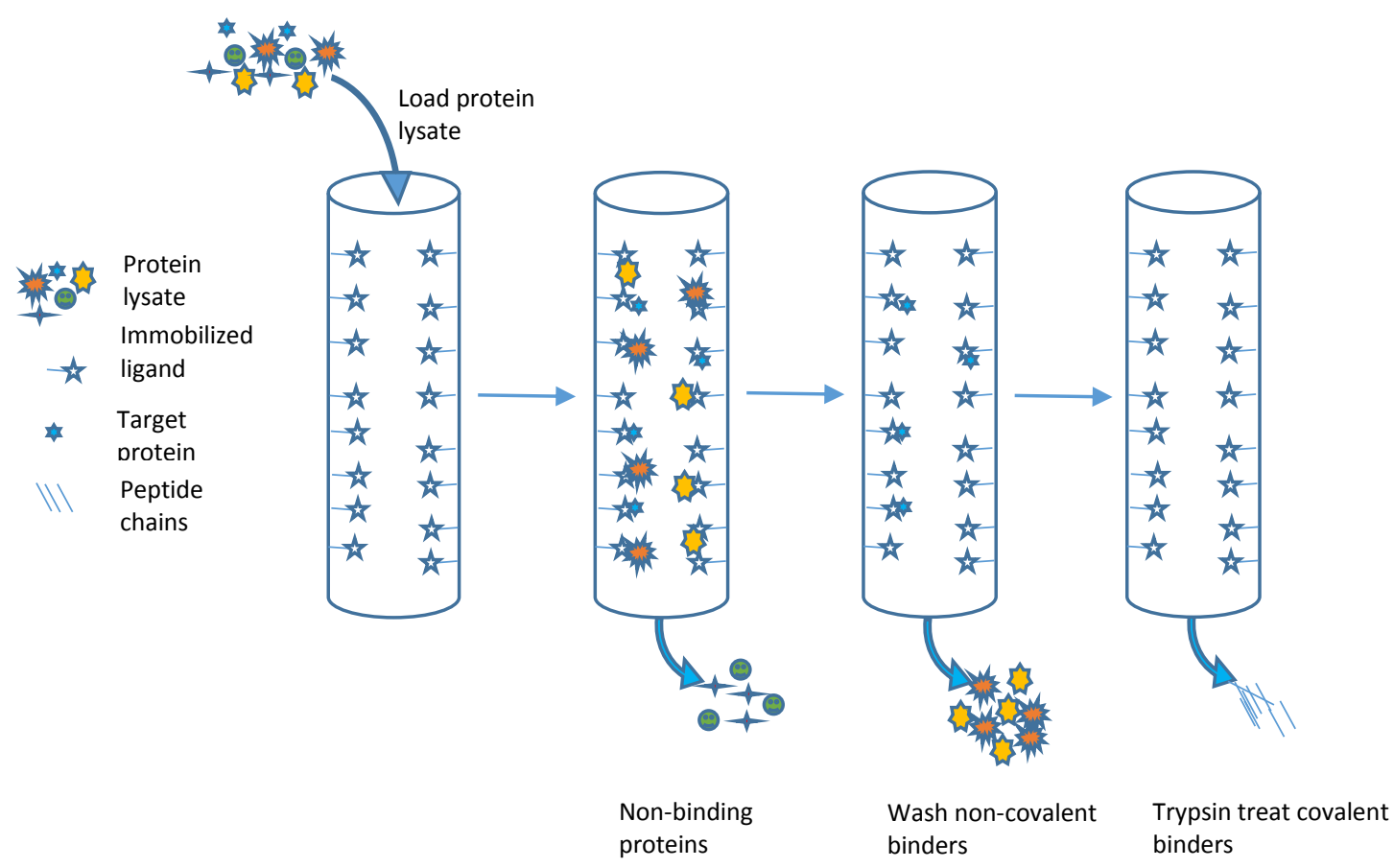

Figure 1.2. Classic affinity purification for drug target discovery, involving direct immobilization of the bioactive compound onto a solid resin. (Figure adapted from Sleno \& Emili, 2008) 
If the bioactive compound of interest does not contain a suitable functional group (most commonly; an amine, carboxyl, or hydroxyl group) to attach to the resin, chemical synthesis of an appropriate functionalised analogue of the compound is required. The resulting analogue will then need to be evaluated as to whether it retains the required target affinity or biological activity (Bantscheff, 2012).

With a method that is successfully able to identify a biologically active compound's target, it is then possible to identify what type of interactions are occurring. Using methods like mechanism-based design, it is possible to design a compound to interact with a biological target in a certain way, giving you an idea of the interactions that could possibly occur. 


\subsection{Mechanism-based inhibitors}

Mechanism-based inhibition is a lesser-used method in drug discovery, but has become an essential method in identifying irreversible inhibitors of target enzymes (Walsh, 1982; Silverman, 1988).

The mechanism-based design approach is split into two types, one is based on having understanding of how a compound undergoes a reaction in the chemistry lab. Applying that idea in context with cells and asking the question, "Is it possible for this mechanism to be catalysed by an enzyme within a cellular environment"? This type will be explored within this thesis.

The second type, which is the reverse of above was used by Borthwick et al. (1998) to identify novel inhibitors of Human Herpes Virus Retinitis Pneumonitis (HHVRP), where Borthwick designed an inhibitor based on the active site of HHVRP. The information generated from the structure and interactions of HHVRP with its substrate, gave Borthwick the required information to identify what chemical mechanism would achieve a covalent mechanism-based attachment to the HHVRP. Borthwick was then able to design a compound with all the requirements shown to be needed to inhibit HHVRP.

Cyclopropanes have been employed frequently in this field due to their high ring strain and their propensity to ring open when exposed to nucleophiles. Nucleophiles are able to attack, breaking the cyclopropane to irreversibly form covalent bonds (Hanzlik et al. 1979; Wiseman \& Abeles, 1979; Paech et al. 1980; Silverman \& Hoffman, 1980).

Mechanism-based design of inhibitors has many challenges to overcome to become a more commonly used method. Understandably, a major challenge is the fear of unexpected side effects through build-up of 
covalently bound non-targets (Overall \& Kleifeld, 2006). This has led to the majority of drug development focusing on non-covalent inhibitors. Interestingly, $35 \%$ of the currently licensed enzyme inhibitors for human use in the USA covalently modify the target or enzyme-substrate complex (Robertson, 2005). These drugs have proven efficacy by targeting binding but more importantly the catalytic mechanism. Since the active moiety of the bioactive molecule is only active to the target enzyme, it proves to be highly specific (Overall \& Kleifeld, 2006).

The interactions between enzymes and substrates or inhibitors are usually non-covalent, for example through hydrogen bonding, electrostatic and hydrophobic interactions, but irreversible covalent modifications can also occur. Suicide inhibitors are a class of inhibitors that utilise an enzyme's catalytic mechanism, to leave the inhibitor covalently attached to the enzyme. These inhibitors are most often used when cell death is the desired outcome, as in the potential treatment of cancers (Ricci et al. 2005). Suicide inhibitors are also used to trigger cell death in the case of antibiotics. The $\beta$-lactam-based antibiotics are a good example of this. Scheme 1.1 shows a ring opening of the penicillin $\beta$-lactams (Labischinski, 1992). The attack at the carbonyl group of the $\beta$-lactam ring, typically by an active site serine of a bacterial transpeptidase, results in the nitrogencarbon bond breaking, and the binding of penicillin through an ester to the enzyme.
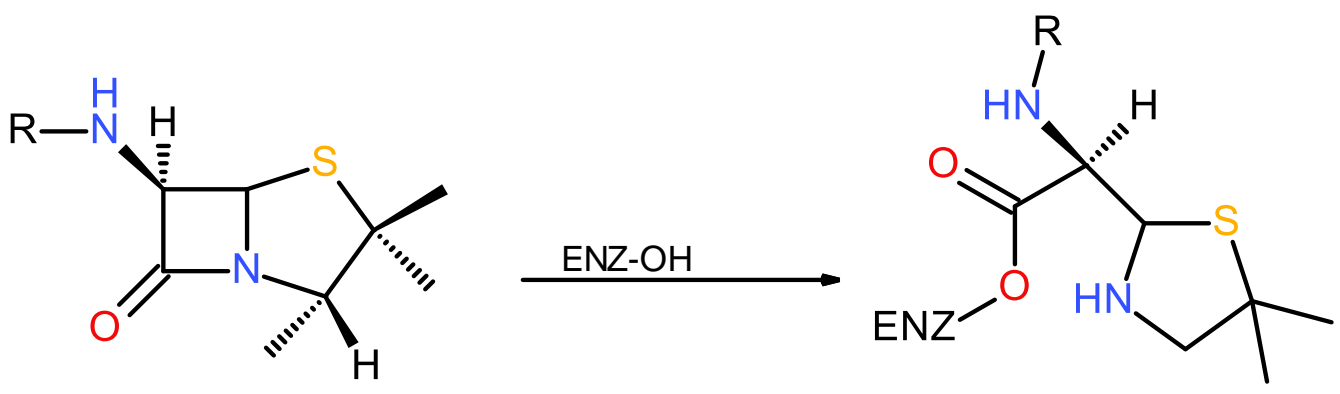

Scheme 1.1. Ring opening of penicillin by transpeptidase 
The work proposed in this thesis will be looking at a class of potential suicide inhibitors that utilise the reactivity of strained functionalised cyclopropanes.

\subsubsection{Cyclopropanated compounds}

Freund reported the first synthesis of cyclopropane $\left(\mathrm{C}_{3} \mathrm{H}_{6}\right)$ in 1881 (Freund, 1881). The compound was discovered to be highly flammable and reactive to nucleophilic attack (Blomberg et al. 1987). Cyclopropanes have also been found to have an anaesthetic effect (Waters \& Schmidt, 1934) as well as some other interesting properties. For example, a cyclopropane has a higher degree of general similarity to an alkene than a cyclobutane (Meijere, 1979; Meijere, 2003). An alkene is usually more reactive than a cyclopropane, but there are no fundamental differences in behaviour (Baeyer, 1885; Meijere, 2003).

Three years after Freund's synthesis of cyclopropane, the first synthesis of a cyclopropane derivative was reported (Perkin, 1884). Current research on the chemical and biological uses of cyclopropanes continues to provide advances in understanding their utility (Meijere, 2003). The cyclopropane ring has biological relevance as it has high torsional strain and is susceptible to nucleophillic attack, for example by proteins (Wong et al. 1989).

Thousands of cyclopropane containing compounds have been characterised (Brandt \& Wessjohann, 2003), with many being biologically active. Cyclopropane moieties appear to be involved in some interesting enzyme catalysed reactions, including the inhibition of methanol dehydrogenase (Frank et al. 1989). These biologically active cyclopropanated structures found naturally makes them useful tools for enzyme inhibitor design. Cyclopropanes are found in several natural 
product classes, including hormones, amino acids, fatty acids, alkaloids, and terpenoids.

The importance of cyclopropanes relates in part to the properties that they engender on their parent molecule. An increase in overall rigidity, activity through constraint in flexibility and also potential energy (created by torsional and ring strain) of cyclopropane-containing molecules, can be factors that help drive further reactions towards opening the cyclopropane (Chu-Moyer \& Danushefsky, 1993). An enzymatic nucleophile can attack the cyclopropane and form a covalent bond, as occurs with dihydrofolate reductase with cyclopropane substituted pteridine and pyrimidine in schemes 1.3 \& 1.4 (Haddow et al. 1987; Suckling, 1988). The resulting enzymatic attack on a cyclopropane causes inhibition by leading to the ring opening of the cyclopropane and irreversible inhibition as the enzyme is covalently attached. (Haddow et al. 1987; Suckling, 1988 Chu-Moyer \& Danushefsky; 1993).

Harnessing cyclopropanes that undergo ring opening or breaking reactions that lead to irreversible inhibition is the ideal outcome in the research proposed here. The active compounds described in this chapter contain a cyclopropane with a carbohydrate backbone, together are known to undergo catalytic ring opening and ring breaking reactions. 


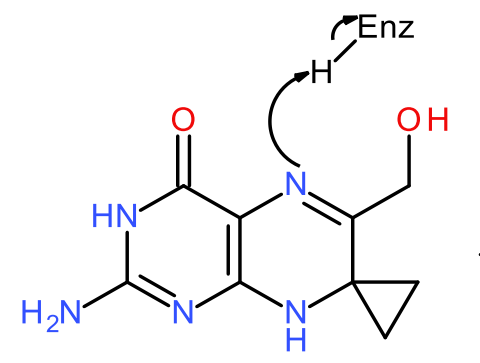<smiles>CCCCC1(CC)CC1CC1=C(CO)Nc2nc(N)[nH]c(=O)c2N1</smiles>

Scheme 1.2. Cyclopropanated pteridine as a mechanism-based inhibitor of dihydrofolate reductase<smiles></smiles><smiles>Nc1nc(N)c(-c2ccc(Cl)cc2)c(C2CC2)[nH+]1</smiles><smiles>CC(C)NCC/C=C1/NC(N)=NC(N)=C1c1ccc(Cl)cc1</smiles>

Scheme 1.3. Cyclopropanated pyrimidine as a mechanism-based inhibitor of dihydrofolate reductase 


\subsubsection{Carbohydrate-cyclopropanes}

The incorporation of cyclopropanes into carbohydrates provides interesting chemistry through the combination of the strained cyclopropyl ring with the chirality inherent to the parent carbohydrate. The literature in this field has been based mainly on such compounds as intermediates in the synthesis of bioactive compounds and new synthetic methods, focusing on the pyranoside- and furanoside-based carbohydrates (Meldgaard \& Wengel, 2000; Hewitt \& Harvey, 2010). Examples include the synthesis of seven-membered rings and their application in the synthesis of natural products and analogues (Brandt \& Wessjohann, 2003).

1,2-Cyclopropanated carbohydrates can be synthesised by the addition of a carbene to a glycal. Many (protected) glycals are commercially available, while they are also simply synthesised from the corresponding sugar. 1,2-Cyclopropanated carbohydrates are very interesting as they can undergo a range of ring expansion and ring breaking reactions. The ring expansion reactions provide oxepines and ring breaking leads to 2-Cbranched pyranosides (Hewitt \& Harvey, 2010; Moore, 2012).

Schemes 1.4 and 1.5 depict a reaction of a cyclopropanated carbohydrate with a nucleophile which attacks the C-1 of the sugar; the product is a 7-membered ring formed through ring expansion (Salaün, 2000). The ring expansion can go by either of two pathways. The first (scheme 1.4) results in the loss of the C-3 substituent, which is promoted by a Lewis acid or electrophile, resulting in an unsaturated product. The second pathway results in the loss of a leaving group from the C-7 position ( $X=$ halogen, hydrogen), as shown in scheme 1.5. Several research groups have studied cyclopropane ring expansions of functionalised gemdichloro-1,2-cyclopropanated carbohydrates (Hewitt \& Harvey, 2010), for example, leading to oxepines following ring expansion in refluxing tolvene in the presence of a nucleophile under basic conditions (Jayaraman \& Ganesh 2008; Jayaraman \& Ganesh 2007). 
Another method of cyclopropane ring opening results in the C-2branched pyranoside (Hewitt, 2008). Scheme 1.6 shows a generalised mechanism for this transformation as proposed by Hewitt. There are numerous potential rearrangement reactions that can then follow such reactions of the cyclopropanated sugar.

The mechanisms described above have the potential of being able to be catalysed by an enzyme. A potential enzyme will need a nucleophile, electrophile a binding site that will accommodate the cyclopropanated sugar. If an enzyme has the right characteristics, these compounds may covalently bind to that enzyme (scheme 1.6). In the absence of an external nucleophile a cyclopropane sugar can react through an intermolecular cyclisation with the c-6, resulting in the generation of a bicyclic compound (Hoberg \& Cousins, 2000). These reactions illustrate the general mechanisms associated with breaking of the cyclopropane ring. (Hoberg \& Bozell, 1995).

In summary, cyclopropanated sugar derivatives can undergo reactions with nucleophiles and electrophiles that lead to either:

i) Ring-opening of the cyclopropane, giving carbohydrate-like pyrans with variant $\mathrm{C}-2$ substitution or

ii) Ring expansion of the pyran, giving oxepines.

In both cases, either a catalyst, promoter or harsh reaction conditions are required and the nucleophile is covalently bonded to the $\mathrm{C}-1$ position. 


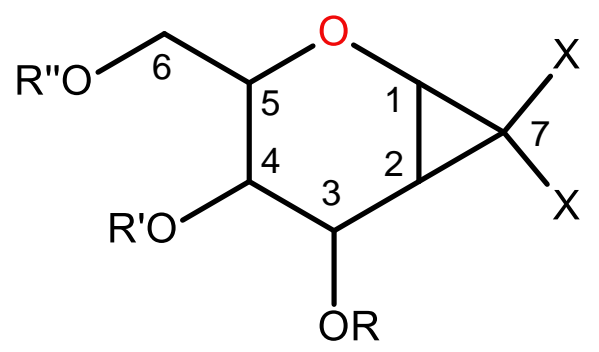

Figure 1.3. Structure of cyclopropanated carbohydrate, showing numbers of carbons.

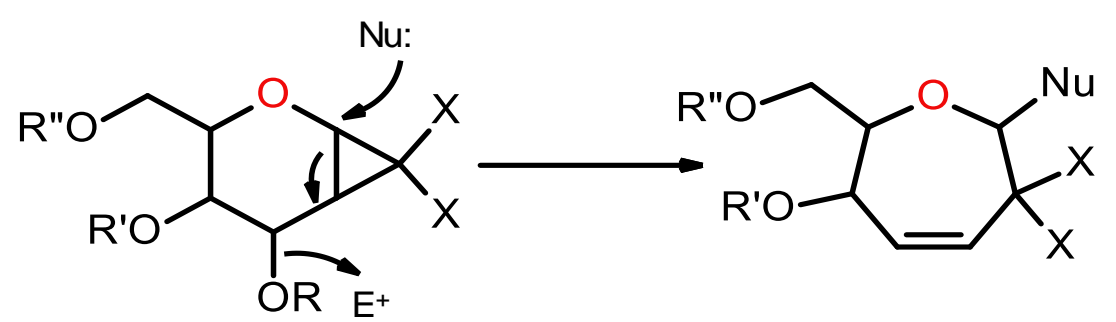

Scheme 1.5. Nucleophile-mediated ring expansion with the loss of C-3 substituent<smiles>[R]O[R]C1C([R])C=C([X])C(N)OC1CO[R]</smiles>

Scheme 1.4. Nucleophile-mediated ring expansion with the loss of C-7 substituent 


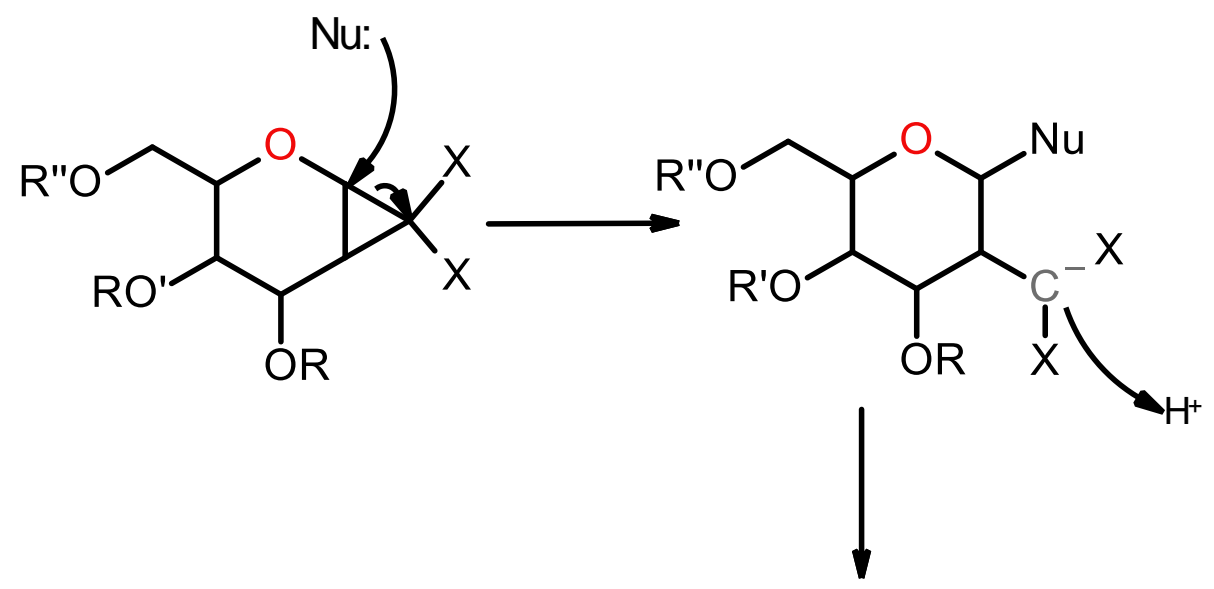<smiles>[X]/C=C1/C(N)OC(CO[R])C([R])C1O[R]</smiles>

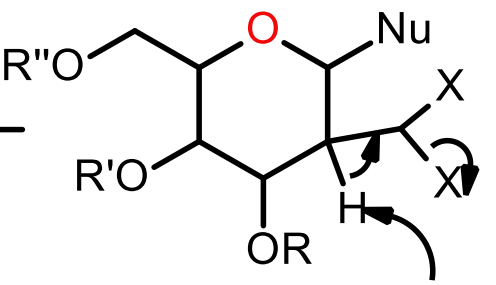

Base

Scheme 1.6. Nucleophile-mediated ring breaking with the loss of $\mathrm{C}-7$ substituent through a stabilised carbanion intermediate.

Designing bioactive compounds based on carbohydrates offers many benefits including: cost effectiveness, pre-existing stereochemistry, and well known chemistry. Once a compound of this class has been identified to have bioactivity, it will then be optimised to increase the associated toxicity. 


\subsection{Yeast as a model organism}

Saccharomyces cerevisiae (baker's yeast) is a valuable tool for the search of novel therapeutic agents. S. cerevisiae screens are inexpensive and often quicker and simpler to run compared to mammalian screens. The unicellular S. cerevisiae are small in size and are able to double in $90 \mathrm{~min}$ under optimum conditions.

The yeast genome consists of 16 chromosomes; 6400 open reading frames (ORFs) of which 1000 genes are classed as "essential". This term is given to genes that once deleted leaves the yeast non-viable. Over 4800 genes are non-essential and have been replaced singly by integration of an antibiotic resistance marker and synthetic barcode sequence to create a comprehensive non-essential deletion mutant array (DMA). This has given rise to a yeast genome deletion set (YGDS) which comprises of $\sim 4800$ strains that each have a single non-essential gene deleted. The deleted gene is replaced by a gene cassette (KanMX4) conferring resistance to kanamycin. The cassette is accompanied by a unique molecular bar code surrounding every gene deletion. The YGDS is a tool that can be used to determine pathways in which compounds may act, by identifying strains that are either hyper-sensitive or resistant compared to the wild type of yeast as described by Tong et al. (2004). High throughput drug assays make it possible to categorise compounds that can act on particular pathways or processes.

The S. cerevisiae genome has been completely sequenced and has a relatively low number of genes and associated proteins compared to mammalian cells, making it a simple medium to use (Geoffeau et al. 1996). S. cerevisiae also has other important factors that make it a model organism for the study of genetic disorders in humans. Almost 1,000 yeast genes have orthologs that are implicated in human disease. S. cerevisiae 
can also mimic multiple human disease, through genetic manipulation (Botstein et al. 1997; Kataoka et al. 1985). This fact has been a driving force in the importance of using yeast as the first stepping stone in the discovery of new drugs that can treat or prevent the progression of a human disease.

A study by Andrade and colleagues identified 285 yeast proteins that are similar to 155 proteins associated to human disease (Andrade et al. 1998). If one is to inhibit a protein in yeast, then most likely, a similar protein in humans will also be inhibited (Bork et al. 2004). This gives a direct method for testing inhibitory drugs in a robust, easily cultured, simplified and wellcharacterised system. One such example is the immunosuppressant compound FK506 that has an inhibitory concentration $\left(\mathrm{IC}_{50}\right)$ of $9 \mathrm{nM}$ and was found to inhibit calcinuerin function in yeast (Breuder et al. 1994). As well as human diseases, $S$. cerevisiae also represents an entry point for identifying antifungal agents (Joyce \& Palsson, 2006).

What has been presented here in this introduction gives a pathway to drug development; from synthesising a new compound, to identifying its potential in the future of drug design. All together this leads to a hypothesis that will be explored as part of my Masters in Biomedical Science based on carbohydrate-based cyclopropanes and their potential use in drug development. 


\subsection{Research hypothesis and objectives}

Cyclopropanated sugars that can undergo ring opening or ring expansion reactions have ideal characteristics for suicide inhibitors. The research hypothesis will be tested to determine whether these reactions (scheme 1.4, 1.5 and/or 1.6) can be utilised in drug development. These reactions do not occur at a significant rate naturally without the use of strong nucleophiles, activators or high temperatures which make them ideal substrates for enzymes. Addition of a protein may provide nucleophilic and catalytic functionalities either ring opening or ring expansion, providing the products at ambient temperatures. If the nucleophile was provided by the protein, this would leave the binding site alkylated by the bioactive substance. It is proposed that there will be a limited number of proteins that will provide the essential functionality and capacity to both bind the artificial substrate and complete the reaction, resulting in good target selectivity.

The main objectives of this research are to

1) Prepare a range of cyclopropanated glucal-derived compounds;

2) Conduct a structure activity relationship (SAR) analysis to determine the most active compound against S. cerevisiae;

3) Identify potential pathways of interactions by chemical genomics; and

4) Determine protein targets by mass spectrometry

\section{1) Prepare a range of cyclopropanated compounds}

Starting with glucal, a range of cyclopropanated compounds will be synthesised to create a small library. The derivatives are designed to provide information on which proposed ring opening/ ring expansion mechanism is taking place within the cell. 
2) SAR analysis to determine the most active compound against $S$. cerevisiae

Each compound that is made will be subjected to an $I C_{50}$ analysis in $S$. cerevisiae. In addition to identifying a lead compound, structural features that promote or supress activity will be determined and a likely mechanism for any covalent modification be proposed.

\section{3) Identify potential pathways of interactions by chemical genomics}

The lead compound from 2 (above) will be subjected to a chemical genomic screen to identify any pathways that are being affected in yeast. The lead compound will also be subjected to an assay to determine whether it is cytotoxic or cytostatic.

\section{4) Determine protein targets}

A parallel study to 3 (above) will be to modify the lead compound to allow for an attachment point of a matrix or molecular probe. Ideally this will be achieved without a decrease in activity. The lead compoundprobe will be then treated with $S$. cerevisiae cell lysate. Target proteins will be isolated by use of sepharose resin and identified by tryptic digest and MS/MS to determine the protein target.

This thesis is split into two general threads, chapter two focuses on the chemistry aspect, and chapter three has the emphasis on the biological testing of the compounds synthesised in chapter two. 


\subsection{CHEMISTRY}

\subsection{Aim and Objectives}

The aim of this chemistry was to design and synthesis a range of cyclopropanated carbohydrates in order to identify a lead compound. The lead compound would then be carried through to the biological testing which is discussed in chapter 3 . The objectives outlined in section 1.6 that will be addressed here include;

1) To prepare a range of cyclopropanated compounds

4) Determine protein targets

The structure of each compound presented with this thesis is numbered as depicted in figure 2.1. This is in accordance to IUPAC recommendations.<smiles>[R6]C[C@H]1OC=C[C@@H]([R20])[C@@H]1[R20]</smiles><smiles>[R6]C[C@H]1OC2=C(C2([X])[X])C([X])([R20])[C@@H]1[2H]</smiles> 


\subsection{Introduction}

\subsubsection{Cyclopropanes}

In 1959 Simmons and Smith discovered a procedure that produced cyclopropanes from alkenes with carbenes without side products usually present in other methods current at the time (Simmons \& Smith, 1959). Their method involves treatment of an alkene with $\mathrm{CH}_{2} \mathrm{l}_{2}$ and a zinc-copper couple, and is thought to go through an organozinc intermediate. A high degree of stereoselectivity can be achieved, for example when directed by a hydroxyl group. The zinc coordinates to the oxygen species which directs the reaction to occur on the same face as the oxygen functionality. This is shown in scheme 2.1, where the cyclic allylic alcohol (cyclopent-2-en-1-ol) is cyclopropanated forming the bicyclic alcohol (bicyclo[3.1.0]hexan-2-ol).

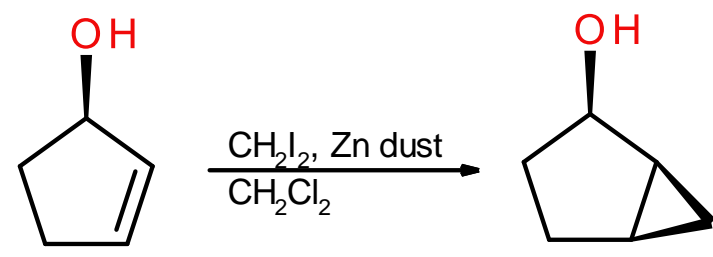

(1R)-cyclopent-2-en-1-ol

(1S,2R,5R)-bicyclo[3.1.0]hexan-2-ol

Scheme 2.1. Synthesis of biocylo[3.1.0]hexan-1ol by Simmons and Smith methodology.

gem-Dihalocyclopropyl groups are important functional groups in organic chemistry. They provide routes to functionalised and unfunctionalised cyclopropanes, including those found in natural products. gem-Dichloro/ gem-dibomocyclopropanes are synthesised by the addition of a carbene, through the treatment of an alkene with chloroform or bromoform. The Makosza dichlorocarbene addition is directed by steric bulk, such that 
addition occurs on the opposite face to the C-3 substituent, due to the C3 hydroxyl protecting group blocking the top face.

Nagarajan demonstrated the preparation of a range of 1,2cyclopropanated sugars through the Simmons-Smith and Makosza methodologies as exemplified by the reaction of tri-O-benzyl-D-glucal shown in scheme 2.2 (Nagarajan et al. 1997). Firstly, the cyclopropane was synthesised using a zinc-copper couple, $\mathrm{CH}_{2} \mathrm{I}_{2}$ and acetyl chloride in refluxing diethyl ether, producing the "up facing" cyclopropane in $89 \%$ yield. Makosza cyclopropanation with chloroform provided the "down facing" dichlorocyclopropane in $85 \%$ yield. A modified Makosza cyclopropanation was used to synthesise the "down facing" dibromocyclopropane with an $84 \%$ yield, scheme 2.2 .

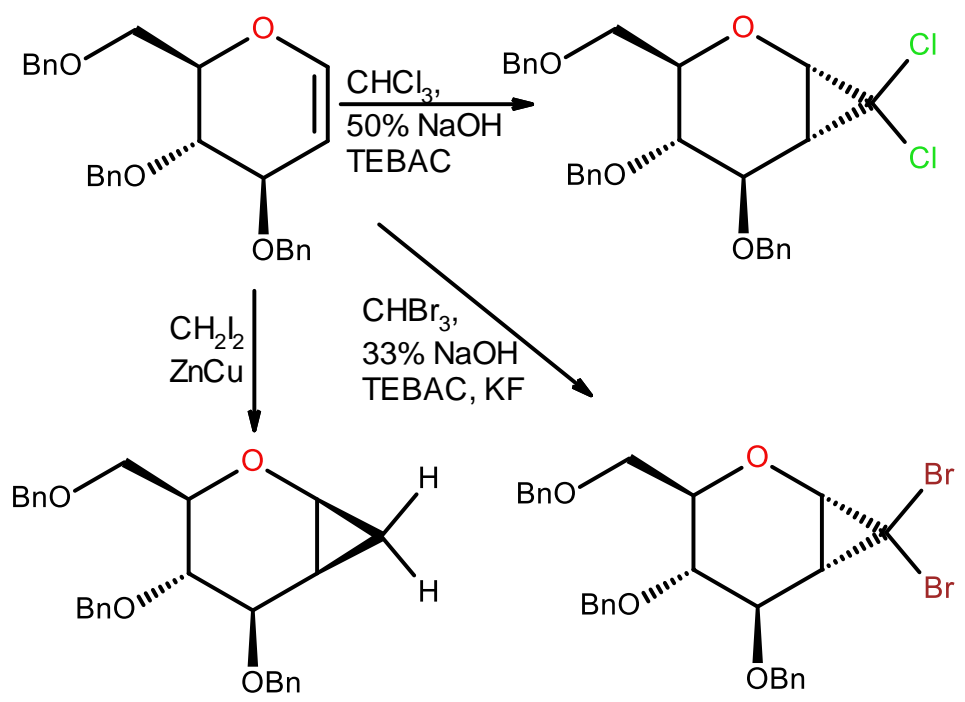

Scheme 2.2. Simmon-Smith cyclopropanation, Makosza dichlorocyclopropanation and modified Makosza dibromocyclopropanation cyclopropanation (Nagarajan et al. 1997).

The above methodology was extended here to the formation of a library of cyclopropanated sugars, varying the oxygen substituents and cyclopropane stereoisomers. The library was created to identify a lead compound and give further evidence towards the likely mechanism introduced in section 1.4.2. The library was extended once the lead compound was identified to further optimise the inhibitory effect on $S$. cerevisiae. 


\subsubsection{Optimising inhibitors}

Once a lead inhibitor is found, it can then be altered to enhance any desirable effects. A study by Marik and colleagues (2011) shows a good example in optimisation of genistein, a known bioactive compound that inhibits breast cancer cell lines (Shah et al. 2004; Marik et al. 2011). To enhance the activity of the anticancer properties, seven derivatives of genistein were synthesised. Marik identified three derivatives that showed a 10-15 increase in toxicity (IC 50 genistein $14 \mu \mathrm{M}, \mathrm{MA}-60.8 \mu \mathrm{M}$ ) against ER positive breast cancer cell lines.

Designing bioactive compounds for biologically known and unknown targets is important to enhance the field of drug discovery. Cyclopropanes have already been shown to be important in mechanismbased inhibition of proteins. However, with a carbohydrate backbone increased protein specificity may occur due to the associated stereochemistry, which is essential towards decreasing negative side effects. Identifying biological targets of these cyclopropane-containing compounds will determine the associated selectivity and, together with chemical genetics, would present a pathway to developing new commercial drugs. To fully utilise chemical genetics it is beneficial to compliment it with chemical proteomics. For this, it is crucial to have a molecular probe that is able to bind to the lead compound and then trap the protein target. Ideally, selective binding will occur. 


\subsubsection{Molecular probes}

The identification of a potential protein target of an active compound can be achieved by the use of a molecular probe (Jeffery \& Bogyo, 2003). Resin-based probes consist of a water-insoluble matrix as well as a linker and a point of attachment, for example an epoxide. (Blanks \& McLaughlin, 1988). Used together with mass spectrometry it is possible to identify proteins that are interacting with the resin; additionally, it is possible to attach the active compound of interest to the linker of the resin and to use that compound as "bait" for the proteins.

Traditionally, a lead compound is developed through SAR, then the identification of the biological target is undertaken if unknown. However, achieving the attachment of an affinity resin without the lead compound losing its activity is a challenge, and in some circumstances impossible. In many situations the compound of interest has to be chemically modified to allow for the attachment of the resin (Leslie \& Hergenrother, 2008). The modification ideally has to have no effect on binding to a target or there is a risk the protein pull-down maybe different to that of the target of the non-resin bound compound.

The incorporation of an azide into the compound of interest allows a wellknown method of attachment to a probe, though the Huisgen Cyclisation chemistry (Huisgen et al. 1984; Moses \& Moorhouse, 2007). Azides react with alkynes in the presence of a copper species, and ascorbic acid (only if Cull) through Huisgen-type cycloadditions. Typically, the copper-assisted Huisgen Cyclisation reaction is the ideal method to react azides with the corresponding alkyne, and is valuable as both azides and alkynes are inert within the cell. The identification of proteins using Huisgen-Cyclisation is shown in scheme 2.3. 

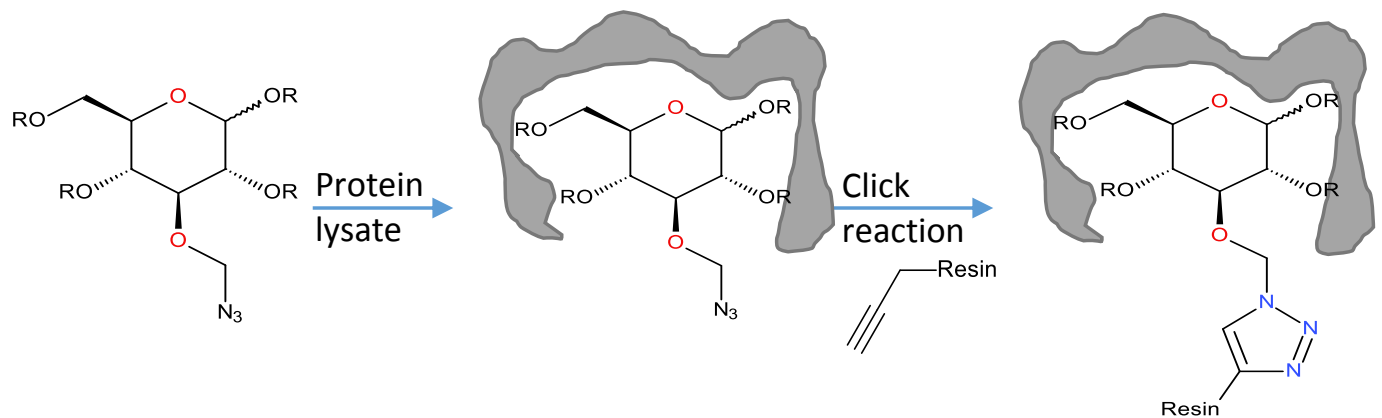

Mass spec

Attached proteins

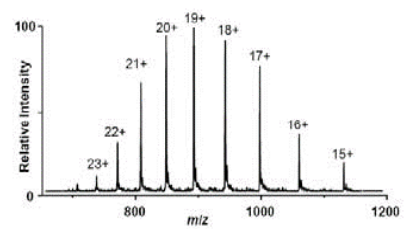

Scheme 2.3. A proposed attachment of a glycoside by a Huisgen Cyclisation reaction to determine protein targets by mass spectrometry 


\subsection{Results and discussion}

\subsubsection{Synthesis of cyclopropanated carbohydrates derivatives 4 to 10 and 13 to 18}

The synthesis of cyclopropanes can be achieved in multiple ways, commonly by the addition of carbenes to alkenes (Simmons \& Smith, 1959). The use of 1,2-unsaturated sugars (glucals) as substrates extends the range of products to highly functionalised stereo-chemically pure systems. This application has been pioneered, based on the research by Simmons and Smith, Makosza (Makosza \& Wawrsyniewicz, 1969), and Nagarajan (Nagarajan et al. 1997). For this project two main glucal substrates were used, 3,4-di-O-benzyl-6-O-trityl-D-glucal (4) and 3,4,6-tri-O-benzyl-D-glucal (28), both of which have a high degree of literature precedence for their cyclopropanation, and are easily made from D-glucose (Gammon et al. 2007; Nagarajan et al. 1997). A general scheme is presented in scheme 2.4.

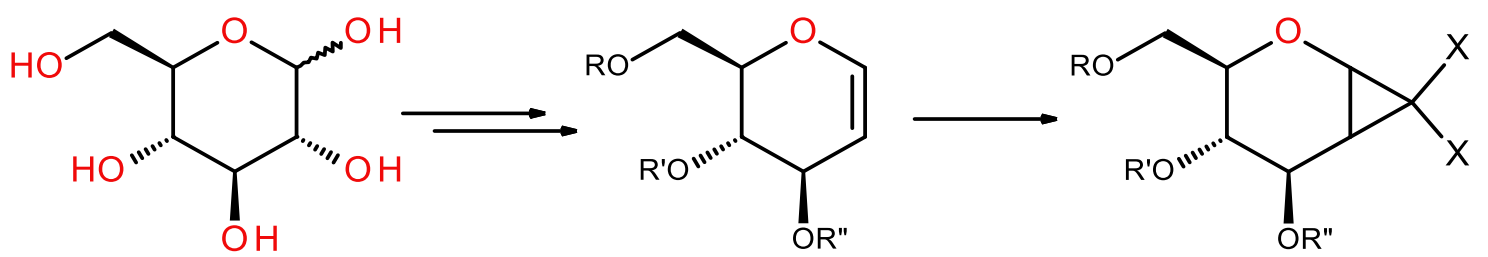

Scheme 2.4. A general scheme of a cyclopropanation from $D$-glucose. $R=B n, T r$; $\mathrm{R}^{\prime} \mathrm{R}^{\prime \prime}=\mathrm{Bn}$

The pioneering work of Emil Fischer and Karl Zach (Fischer \& Zach, 1912) was employed in the synthesis of tri-O-acetyl-D-glucal from $D$-glucose in three steps beginning with acetic anhydride and a catalytic amount of perchloric acid (scheme 2.5). Addition of $\mathrm{HBr}$ in acetic acid provided the a-bromoglycoside as a white solid. This was dissolved in diethyl ether and reacted with zinc in the presence of aqueous acetic acid to provide crude 3,4,6-tri-O-acetyl-D-glucal in 93\% over the three steps. 

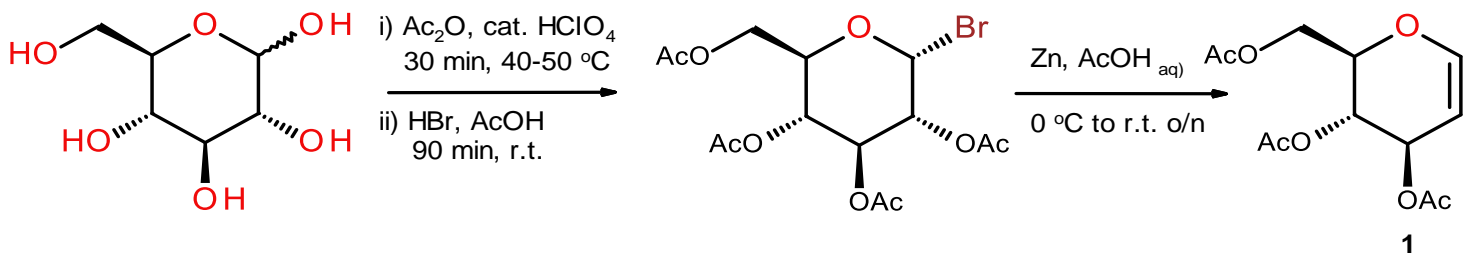

Scheme 2.5. Synthesis of 3,4,6-Tri-O-acetyl-D-glucal 1

The acetyl groups were removed using catalytic sodium methoxide in methanol followed by purification as described by Risseeuw (Risseeuw et al. 2009): The crude product was dissolved in methanol and treated with portions of acetone and then diethyl ether which resulted in the impurities precipitating out; the resulting pure D-glucal was concentrated, providing a pleasing $99 \%$ yield. Selective re-protection of the C-6 hydroxyl with trityl chloride provided 3 in a good yield of $80 \%$ after purification by silica column chromatography. However, this yield was typically only achieved when a pink colour was seen on the addition of the trityl chloride to the pyridine, indicating the presence of the trityl cation. If this was not observed the yield was reduced to ca. $60 \%$ most likely due to wet pyridine. In all cases, the yield based on recovered starting material was typically 97\%, indicating incomplete conversion with wet pyridine. Protection of C-3 and C-4 hydroxyl groups was then achieved with benzyl<smiles>CC(=O)OC[C@H]1OC=C[C@@H](OC(C)=O)[C@@H]1OC(C)=O</smiles>

1<smiles>COCC1OC=C[C@@H](O)[C@@H]1O</smiles>

2<smiles>O[C@H]1C=CO[C@H](CO[Te])[C@@H]1O</smiles>

$\mathrm{BnBr}, \mathrm{Na}$

$\mathrm{DMF}$<smiles>Brc1ccccc1</smiles>

4

Scheme 2.6. Synthesis of 3,4-di-O-benzyl-6-O-trityl-D-glucal (4) 
bromide in DMF and $\mathrm{NaH}$ which provided the desired product 4 as a white solid in a good yield of $93 \%$ (scheme 2.6).

The next step in the synthesis was cyclopropanation, forming nonhalogenated or halogenated (bromide and chloride) cyclopropane derivatives. The simmons-Smith reaction afforded the unsubstituted cyclopropane, while the halogenated derivatives were generated by Makosza cyclopropanation with bromoform or chloroform. The SimmonsSmith method applied $\left.\mathrm{CH}_{2}\right|_{2}$, zinc dust and $\mathrm{Cu}(\mathrm{OAC})_{2}$, whereby the zinc carbenoid intermediate reacts with the alkene $\mathbf{4}$ with high stereoselectivity due to coordination to the C-3 oxygen substituent. Purification afforded 17 as a white solid with yields from 75 to $84 \%$ with characteristic $\mathrm{H}-1$ and $\mathrm{H}-2$ signals in the $1 \mathrm{H}$ NMR spectrum and the two protons on the cyclopropane $(\mathrm{H}-7 \mathrm{a}, \mathrm{b})$ characteristic of the product.

Dibromocyclopropanation was performed as reported by Hewitt and Harvey (Hewitt \& Harvey, 2009) using a suspension of potassium fluoride in a $33 \%(\mathrm{w} / \mathrm{w})$ solution of sodium hydroxide which resulted in yields of between $60-80 \%$ of the major product 13 and yields of the minor isomer 14 between $10-20 \%$. The maximum yield of $80 \%$ was afforded after the reaction time was extended to 5 days. The characteristic $\mathrm{H}-1$ and $\mathrm{H}-2$ signals in the $1 \mathrm{H}$ NMR spectrum were again as distinctive as in 17. An alternative cyclopropanation method with $33 \%$ sodium hydroxide, in the absence of potassium fluoride allowed preparation of the dichlorocyclopropane. Higher yields were achieved with chloroform, with yields between 70 to $85 \%$. Purification by silica column chromatography yielded an off-white powder and colourless oil for the major and minor products, respectively. The $1 \mathrm{H}$ NMR spectrum of the major product $\mathbf{5}$ matched the data of Moore (2012) (scheme 2.7). The diastereomer at C-1, C-2 of 5 and 13 were also prepared in yields of 10 to $20 \%$ 

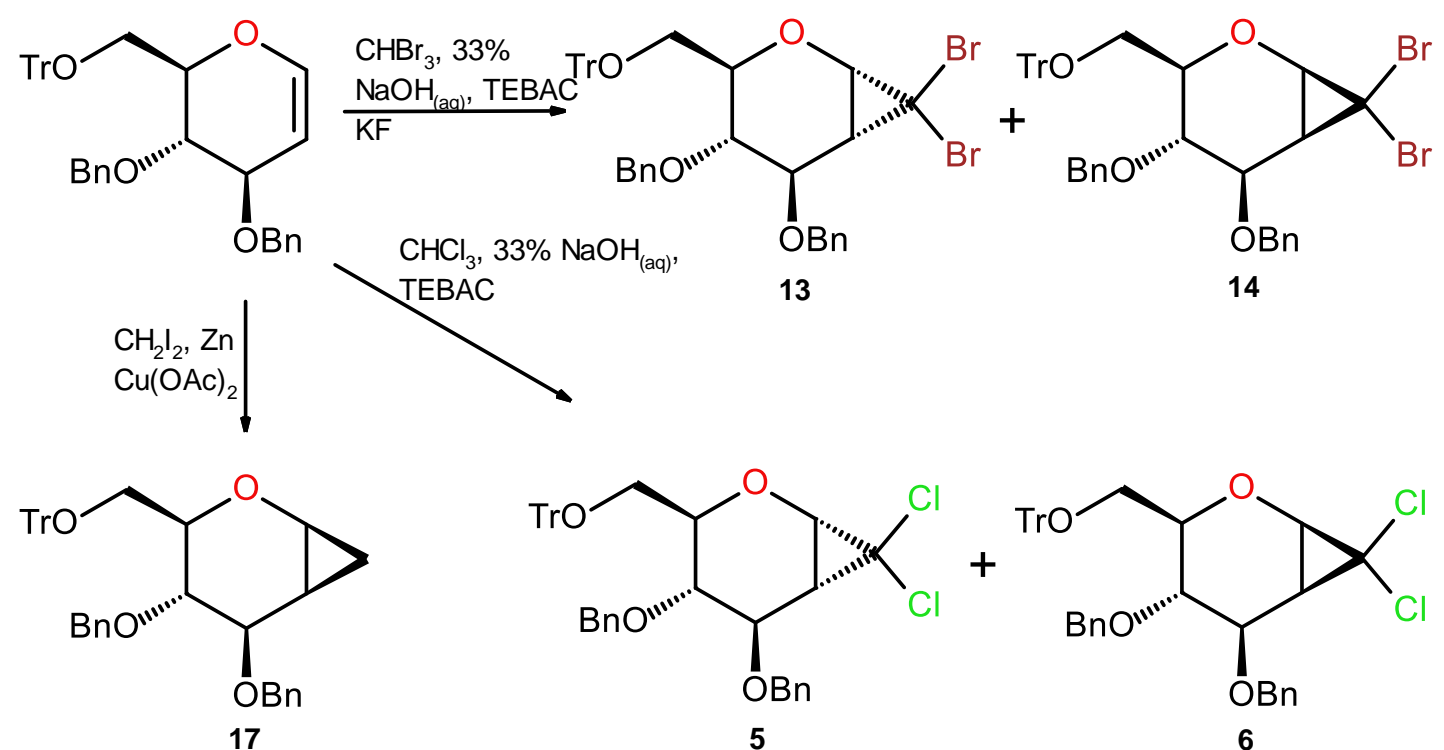

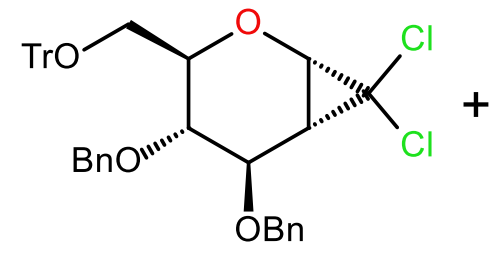

5

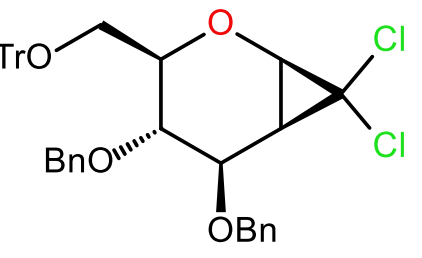

6

Scheme 2.7. Synthesis of 5 and 6,13 and 14 and 17

Removal of the trityl group from the C-6 position of 5, 6, 13, 14 and 17 was done with formic acid in diethyl ether resulted in the corresponding alcohols $7,9,15,16,18$ in a range of yields between 20 and $60 \%$. These low to moderate yields were due to the formation of a formate ester, which was unable to be converted to $6-\mathrm{OH}$ due to the propensity of cyclopropane ring opening under formate deprotection conditions. The amount of formate ester formed depended on time of the reaction, but it was found that the dibromocyclopropanes did not form any formate esters if the reaction was limited to two hours. Concurrent biological testing of compounds $\mathbf{8}$ and $\mathbf{1 0}$ showed that the compounds were inactive (discussed in section 3.4.3) therefore the synthesis of the formate ester dibromocyclopropane was not pursued.

The deprotection of compounds 5 and $\mathbf{6}$ (scheme 2.8) found that two hours provided a good balance of product to formate by-product, as shown in table 2.1. Purification of the mixture by silica column chromatography gave semi-pure dichloro- and dibromocyclopropanes products 7 and 13, further purification by $-14{ }^{\circ} \mathrm{C}$ hexane recrystallisation resulted in pure white powder. The deprotection of 5 and the 


\begin{tabular}{|l|l|l|l|l|}
$\begin{array}{l}\text { Compound } \\
\text { number }\end{array}$ & $\begin{array}{l}\text { Time } \\
\text { hours }\end{array}$ & $\begin{array}{l}\text { Deprotected } \\
\text { OH }\end{array}$ & $\begin{array}{l}\text { Formate } \\
\text { ester }\end{array}$ & $\begin{array}{l}\text { Starting } \\
\text { material }\end{array}$ \\
\hline 7 & 2 & $45 \%$ & $22 \%$ & $20 \%$ \\
\hline 7 & 4 & $39 \%$ & $34 \%$ & $13 \%$ \\
\hline 7 & 6 & $21 \%$ & $68 \%$ & $10 \%$ \\
\hline 13 & 2 & $17 \%$ & $0 \%$ & $58 \%$ \\
\hline
\end{tabular}

Table 2.1. Rate of formate ester formation compared to recovered starting material and desired deprotection.

characterisation of $\mathbf{7}$ and $\mathbf{8}$ was consistent with that of Moore: for $\mathbf{7}$ the characteristic $\mathrm{H}-1$ signal at 3.87 (doublet, ${ }^{3} \mathrm{~J}_{\mathrm{H}-\mathrm{H}}=8.3 \mathrm{~Hz}$ ) and $\mathrm{H}-2$ at 1.84 ppm (doublet of doublets, ${ }^{3} \mathrm{~J}_{\mathrm{H}-\mathrm{H}}=8.6,3.9 \mathrm{~Hz}$ ) peaks of the cyclopropane and the aromatic region (7.43 - 7.29 ppm) showing only 10 protons, consistent with two benzyl protecting groups (C-3 and C-4). The formate ester 8 displayed very similar peaks for $\mathrm{H}-1$ and $\mathrm{H}-2$ and the 10 aromatic protons. However, there was an $\mathrm{H}-8$ formyl proton at 8.03 ppm (quartet, ${ }^{3} \mathrm{~J}_{\mathrm{H}-\mathrm{H}}=0.7 \mathrm{~Hz}$ ) which corresponded to the formate ester.

The same characterization technique was used to identify 9 and 10 , formed from the deprotection of dichlorocyclopropane 6 . The characterization of $\mathbf{9}$ and $\mathbf{1 0}$ were again consistent with that of Moore (2012): for 9 the characteristic $\mathrm{H}-1$ at 3.97 (doublet, $3{ }_{\mathrm{H}-\mathrm{H}}=9.4 \mathrm{~Hz}$ ) and $\mathrm{H}-2$ at $2.13 \mathrm{ppm}$ (triplet, $3 \mathrm{~J}_{\mathrm{H}-\mathrm{H}}=8.2 \mathrm{~Hz}$ ) peaks of the cyclopropane and the aromatic region (7.43-7.29 ppm) showing only 10 protons. The formate ester 10 displayed very similar peaks for $\mathrm{H}-1$ and $\mathrm{H}-2$ and the 10 aromatic protons. However, there was an $\mathrm{H}-8$ proton at 8.00 ppm (singlet) which corresponded to the formate ester.

In the interest of generating a library of compounds all side products where kept for the biological studies to determine SARs. 


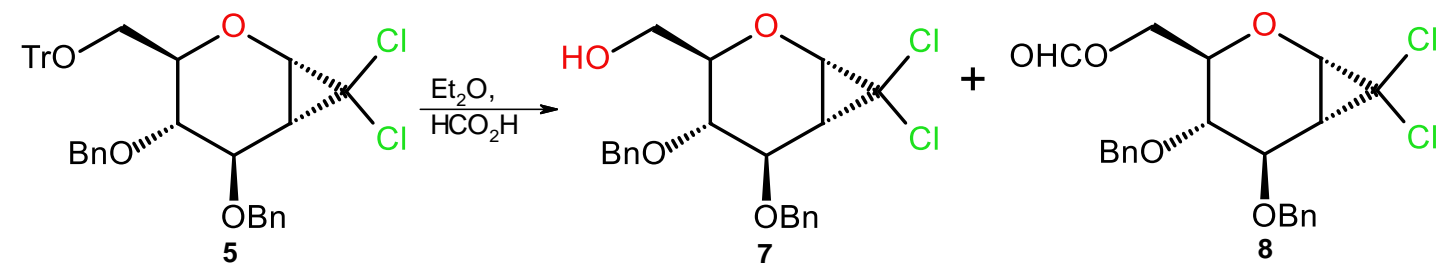

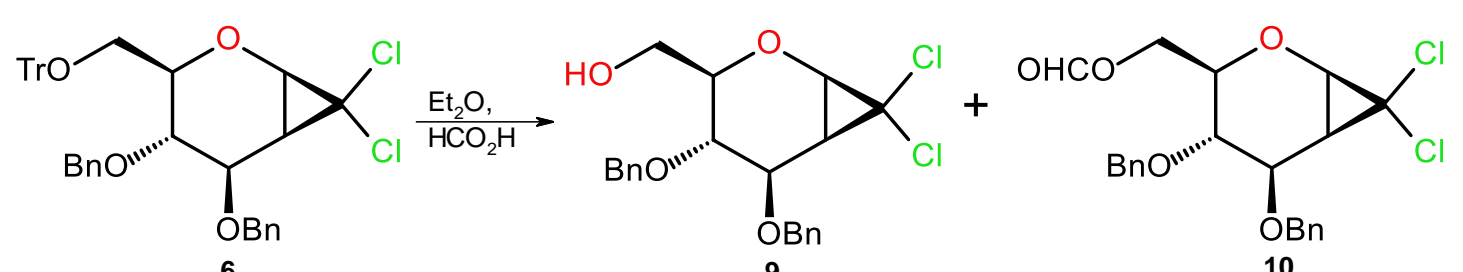

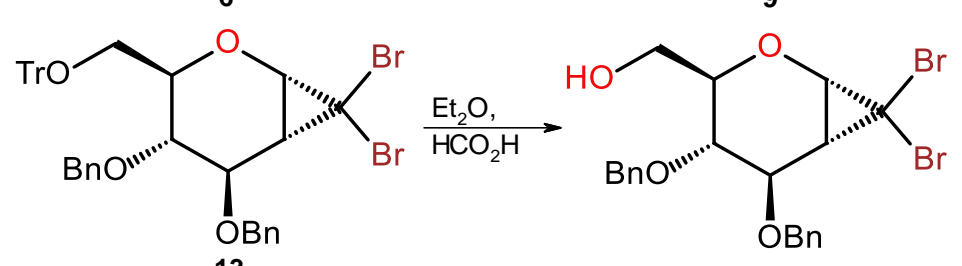

13

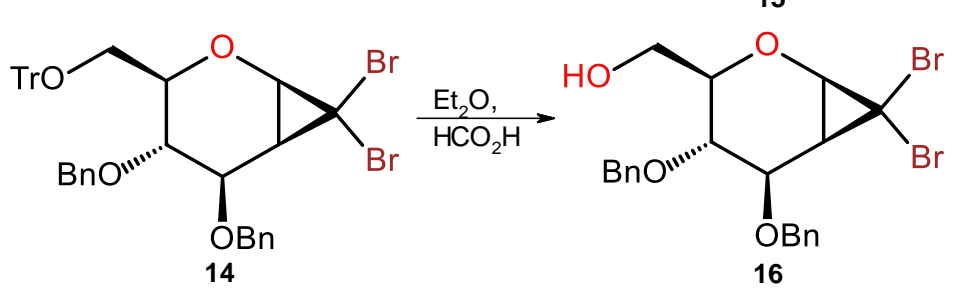

Scheme 2.8. Synthesis of compounds 7 and 8, 9 and 10, 15 and 16.Figure 2.1. Guide to numbering glucals (left), and carbohydrate-cyclopropanes (right). 


\subsubsection{Synthesis of cyclopropanated carbohydrate derivatives 29 to 33}

Compound $\mathbf{2 9}$ was has been reported in the literature to be active against HeLa cell lines (Sanhueza et al. 2007), it was decided to synthesise this compound to compare whether the activity can also be found in yeast. The dibromocyclopropane $\mathbf{3 2}$ was also synthesised to determine if the activity of $\mathbf{2 9}$ was related to the possible mechanism of inhibition.

As described previously, the deprotection of the tri-O-acetyl-D-glucal was achieved by the use of catalytic sodium methoxide in methanol followed by purification. The resulting pure D-glucal 2 was obtained in a $98 \%$ yield. Subsequent re-protection with benzyl bromide provided the desired tri-Obenzyl-D-glucal $\mathbf{2 8}$ as a white solid in a good yield of $80 \%$ (scheme 2.9).

The tri-O-benzyl-D-glucal was then subjected to dichlorocyclopropanation which resulted in a $\mathbf{7 9 \%}$ yield of the desired major product $\mathbf{2 9}$ with no minor 30 product being observed initially. However, on repeating the reaction the minor isomer was observed in $12 \%$ yield along with the major isomer in $82 \%$ yield. As previously mentioned the characteristic NMR signals of $\mathrm{H}-1$ and $\mathrm{H}-2$ were used to identify the products of cyclopropanation reactions.

The tri-O-benzyl-D-glucal was also subjected to dibromocyclopropanation providing a yield of $65 \%$ of the major isomer 32 and $14 \%$ of the minor isomer 33. Complete deprotection of the benzyl groups within $\mathbf{2 9}$ was accomplished by hydrogenation with $\mathrm{H}_{2}$ and catalytic $\mathrm{Pd} / \mathrm{C}$, in methanol with catalytic acetic acid, as described by Murali (Murali et al. 2007) albeit with alterations to the temperature. Heating of the reaction mixture was effective in dissolving the tribenzyl derivative more effectively. Purification through a silica plug afforded an $83 \%$ yield of the triol 31. Compound $\mathbf{3 1}$ was used as a substrate in later reactions. 


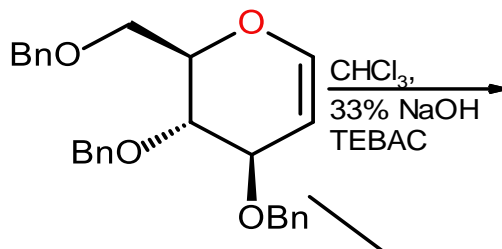

$28 \mathrm{CHBr}_{3}$ $33 \% \mathrm{NaOH}$ TEBAC, KF<smiles>ClC1(Cl)[C@H]2O[C@H](CO[B]c3ccccc3)[C@@H](OBr)[C@@H](OBr)[C@@H]21</smiles>

29<smiles>[3H][B]OC[C@H]1OC2C([C@@H](O)[C@@H]1OBr)C2(Cl)Cl</smiles>

30

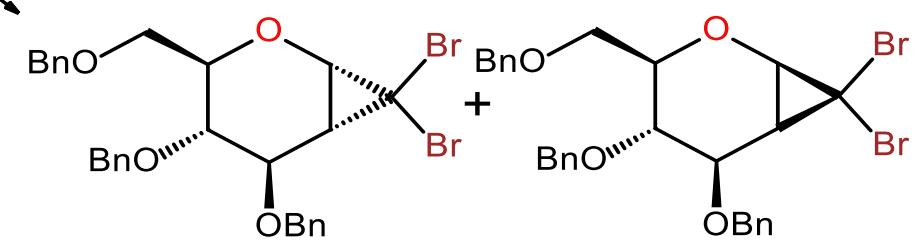

32

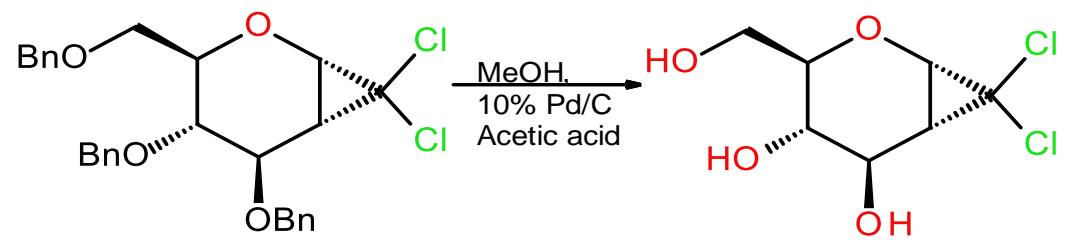

29

31

Scheme 2.9. Synthesis of $\mathbf{2 9}$ and $\mathbf{3 0}, \mathbf{3 1}$ and $\mathbf{3 2}$ and $\mathbf{3 3}$ 


\subsubsection{Synthesis of cyclopropanated carbohydrate derivatives 25, 26, 27 and 31}

To increase the scope of the SAR study, a range of compounds were prepared with partial protection of the hydroxyl groups at C-3, C-4 and/or C-6. The conditions of the cyclopropanation required protecting groups on C-3, C-4 and C-6 to have partial protection this had to occur after the cyclopropanation steps.

Compound $\mathbf{5}$ was subjected to deprotection of both the trityl and benzyl substituents by hydrogenolysis with catalytic Pd/C, in methanol, as described by Murali, but using warm ethanol as solvent, which provided higher levels of solubility than methanol. The deprotection yielded the triol 31. After 24 hours of stirring under $\mathrm{a} \mathrm{H}_{2}$ atmosphere, four spots developed on the TLC. These were separated by flash chromatography to yield fully and partially deprotected products 25, 27 and $\mathbf{3 1}$ (scheme 2.10).

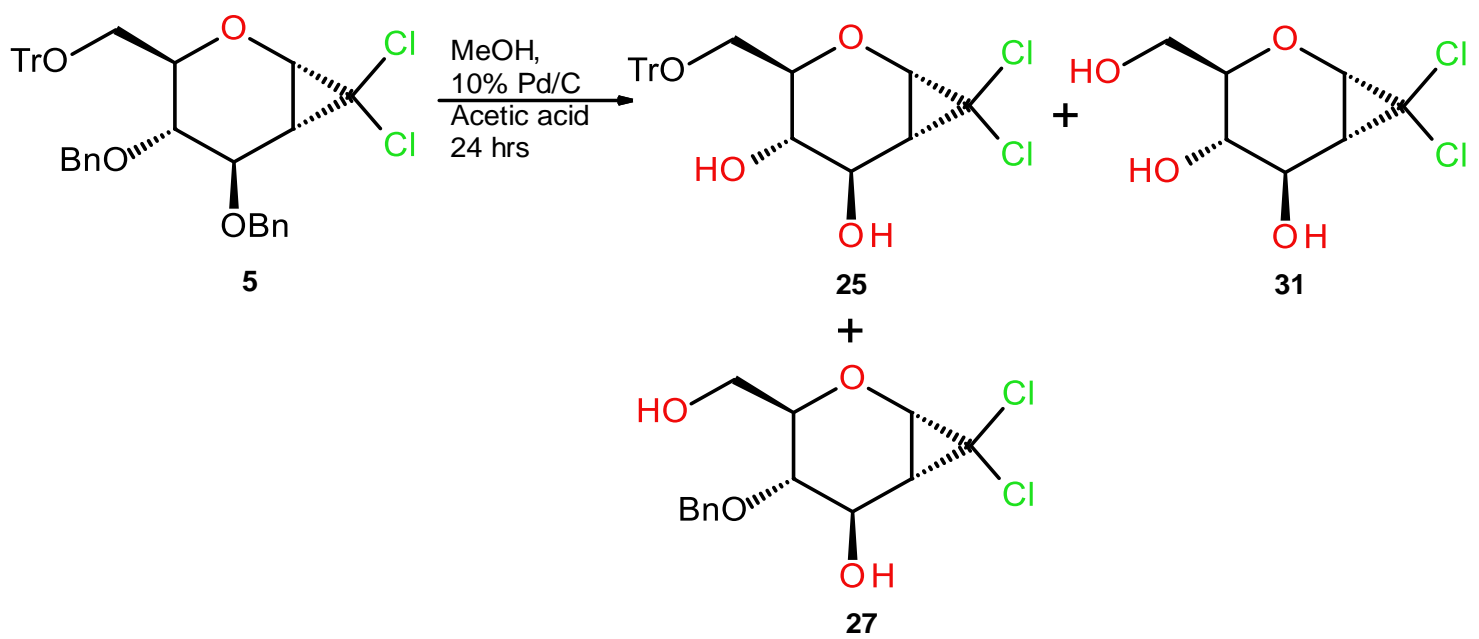

Scheme 2.10. Synthesis of 25, 27 and $\mathbf{3 1 .}$ 


\subsubsection{Synthesis of cyclopropanated carbohydrate derivative 12}

Further derivatisations of the C-6 hydroxyl material were carried out in an attempt to attach either a fluorescent probe or matrix to aid in the identification of any potential protein targets (see section 3.3.10).

A Swern oxidation, pioneered by Swern and Omura (1978) was attempted, with the aim of accessing the C-6 aldehyde. However, over-oxidation was observed, with the alcohol converting to the carboxylic acid 12 as shown in scheme 2.11. The expected aldehyde proton signal was not present in the IH NMR spectra for either the crude or purified product. This was not the original intention but, due to the nature of this project, the carboxylic acid was in itself useful as it could be explored in biological testing and SAR studies, to date compound $\mathbf{1 2}$ has yet to be tested for biological activity. Further oxidations at this stage have yet to be attempted.

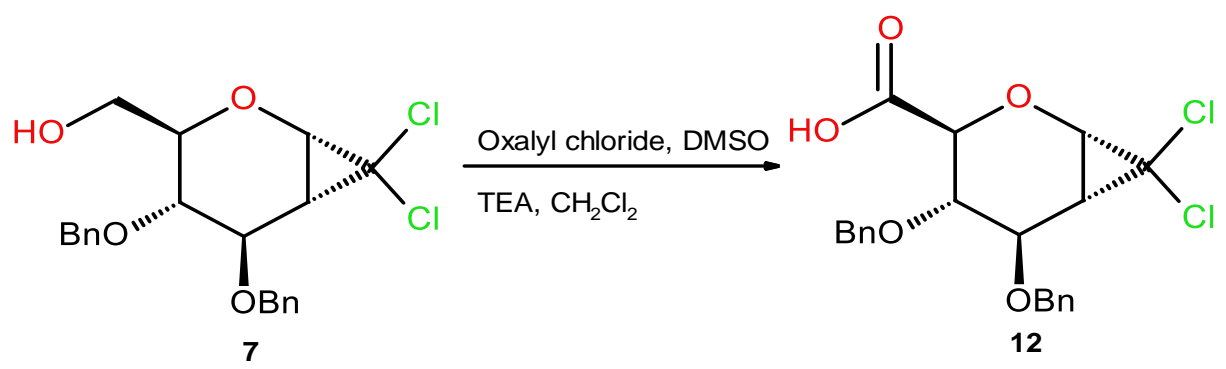

Scheme 2.11. Synthesis of 12 


\subsubsection{Synthesis of cyclopropanated carbohydrate derivative 11}

To further understand which of the proposed chemical mechanisms is occurring within the biological environment (see section 1.6), it was decided to remove one of the chlorides on the cyclopropane as this would decrease the level of carbanion stability. Therefore, the synthesis of 11 was attempted (scheme 2.12). It is known that when gemdichlorocyclopropane carbohydrates are treated with excess $\mathrm{LiAlH}_{4}$, the des-halo product is formed. We attempted to synthesise the mono halide via use of limited equivalents of $\mathrm{LiAlH}_{4}$. Reduction of the chloride of compound $\mathbf{7}$ was decided. At this stage of the project $\mathbf{7}$ was the most biologically active compound. Reduction of the chloride was achieved using $\mathrm{LiAlH}_{4}$ in THF under $\mathrm{N}_{2}$, for three days. Although three products were noted in the TLC of the reaction mixture, only the monochloro derivative 11 could be purified sufficiently for characterisation. The SAR analysis of this compound led to further indication of the mechanism that is occurring within the cell (section 3.4.3).
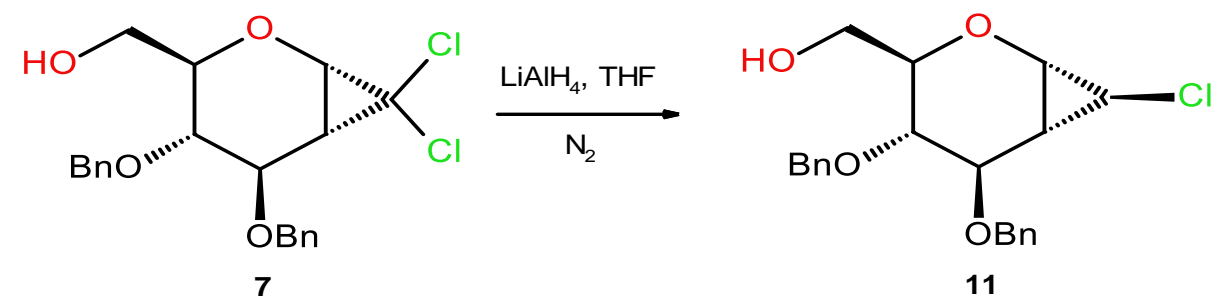

Scheme 2.12. Synthesis of 11 


\subsubsection{Synthesis of compounds 36, 38 and 37; exploration of probe attachment}

With the knowledge that bioactivity may be completely lost if a probe is attached to the C-6 hydroxyl in compound 7, it was decided to attempt to selectively protect either the C-3 or C-4 hydroxyl to probe these sites as likely attachment points of a probe.

Compounds $\mathbf{3 6}$ and $\mathbf{3 7}$ were synthesised in one step from $\mathbf{3}$ as described by Mereyala \& Kulkarni (1989), shown in scheme 2.13. For 370.8 equivalents of benzoyl chloride was added to a solution of $\mathbf{3}$ in DMF and pyridine. Selective protection of the C-3 hydroxyl was observed with a yield of $80 \% 37,8 \% 36$ and $12 \%$ recovered starting material. This method was repeated with 2.5 equivalents of benzoyl chloride with a yield of $95 \%$ 36 was achieved in four hours with no mono protected glucal being observed. Compounds $\mathbf{3 6}$ and $\mathbf{3 7}$ were unable to be cyclopropanated as the conditions of the cyclopropanation (strong aqueous base) are ideal conditions to remove the ester functionalities. Research by Hewitt (2008) showed that under these conditions, the cyclopropanation of the triacetyl glucal 1 was unable to form the corresponding cyclopropane. It was then decided that $\mathbf{3 7}$ could be used to generate selectively a benzyl protected C-4 hydroxyl, this would then allow C-3 position to be deprotected and reprotected with a protecting group that would stay intact in under the cyclopropanation reaction conditions. However prior to this, $\mathbf{3}$ was reacted with one equivalent of benzyl chloride and one equivalent of sodium hydride to determine if there was any selectivity of between C-4

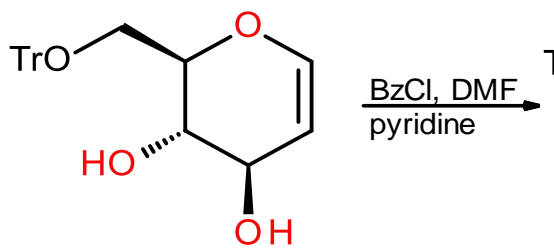

3<smiles>CC(C)OC[C@H]1OC=CC(OC(C)(C)C)[C@H]1O</smiles>

36

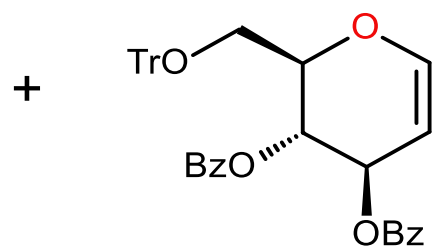

37

Scheme 2.13. Synthesis of $\mathbf{3 6}$ and $\mathbf{3 7}$ 
and C-3 hydroxyl groups in the benzylation. This might occur if the acidity of the proton is influencing the selectivity.

In several instances, different selectivity in mono protection of C-3 and C-4 was observed. The alkylation of 6-O-trityl-D-glucal with one equivalent of benzyl bromide primarily led to the addition of a single benzyl group on the C-4 position of $\mathbf{3}$ to give $\mathbf{3 8}$ (scheme 2.14). This is in accordance with the computational and experimental findings of Hamann et al. (1999), who showed that this selectivity arises as a result of greater acidity of the hydroxyl group at C-4 over other positions. Hamann et al. focus their argument on the stability of the oxyanion at the $\mathrm{C} 4$ position. This is opposite to the outcome of the mono benzoylation of the C-3 and C-4 hydroxyl with benzoyl chloride. The C-3 hydroxyl is preferred due to the accessibility of the site of acylation, the allylic C-3 hydroxyl is also more nucleophilic. It was found that the benzyl protection with one equivalent of benzyl bromide was not as selective as the benzoyl in a parallel experiment, $60 \%$ and $80 \%$ respectively. Although both reactions resulting in $\mathbf{3 6}$ and $\mathbf{3 8}$ were more selective than that previously completed in literature (Mereyala \& Kulkarni, 1989; Moore, 2012).
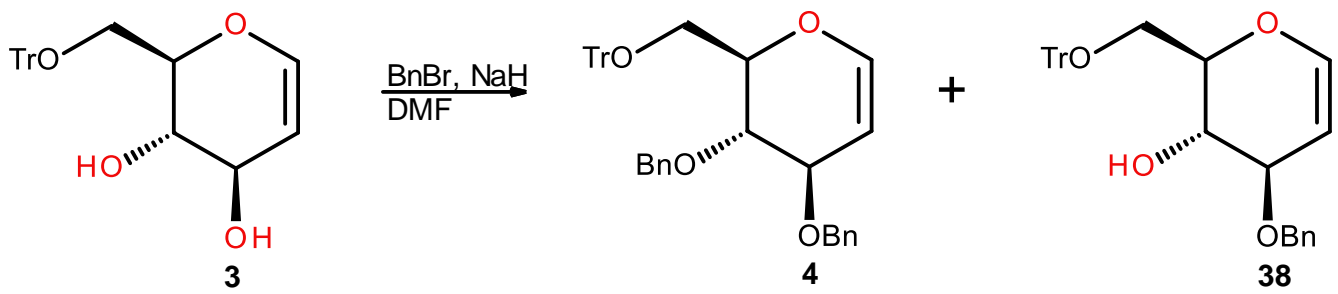

Scheme 2.14. Selective synthesis of $\mathbf{5}$ and $\mathbf{3 8}$ 


\subsubsection{Synthesis of cyclopropanated carbohydrate derivative 24; the probe linker}

Initial reactions were attempted to attach a fluorescein to the C-6 hydroxyl of $\mathbf{7}$ were unsuccessful. These results are not discussed within this thesis. Due to repeated failed attempts of attaching a probe to 7, it was decided to attempt attachment of a probe to the C-3 and/or C-4 position of an analogue of 7. To achieve this, a p-azidobenzyl protecting group was synthesised.

The p-azidobenzyl bromide protecting group was synthesised in two steps from p-tolvidine, as described by Kloss. (Kloss et al. 2011). p-Tolvidine reacted with sodium nitrate in water and $37 \% \mathrm{HCl}$ to form a diazonium salt that, upon treatment with sodium azide, afforded p-azidotolvene 19 as a bright orange liquid in a yield of $70 \%$. The radical bromination of $p$ azidotolvene was carried out as described by Mornet and colleagues (Mornet et al. 1984) utilising AIBN and NBS, and provided the desired product in $80 \%$ yield (scheme 2.15). Care was needed during purification by silica chromatography due to the nature of silica being nucleophilic and able to react with p-azidobenzyl bromide. As long as the column was completed within 10 min, pure p-azidobenzyl bromide $\mathbf{2 0}$ was obtained in a good yield of $79 \%$. Personal care was taken due to the tendency of $\mathbf{2 0}$ to act as an irritant (greater than that of benzyl bromide).<smiles>Cc1ccc(N)cc1</smiles>

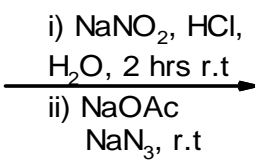<smiles>Cc1ccc([N+]#N)cc1</smiles>

19 i) NBS, AIBN $\stackrel{\text { Benzene, reflux }}{5 \mathrm{hrs} \text {, r.t }}$<smiles>[N]c1ccc(CBr)cc1</smiles>

20

Scheme 2.15 Synthesis of $\mathbf{2 0}$ 
For selective p-azidobenzyl protection of the C-4 hydroxyl group of $\mathbf{3}$, two equivalents of 6 -O-trityl-D-glucal $\mathbf{3}$ was added to one equivalent of $p$ azidobenzyl bromide. Selective protection of C-4 hydroxyl group was observed and 22 was identified by proton NMR and HMBC. A modest $63 \%$ yield was achieved after purification by silica chromatography. p-Azidobenzyl protection at the C-3 hydroxyl group of the 6-O-trityl-D-glucal was not observed in TLC or crude NMR. This observation was expected as previously discussed. Further protection of the C-3 hydroxyl was completed with the addition of $\mathrm{NaH}$ and $\mathrm{BnBr}$ in $\mathrm{DMF}$ as described previously (section 3.4.6), this resulted in the fully protected glucal required for the dichlorocyclopropanation reaction. However the cyclopropanated sugar did not form under Makosza cyclopropanation conditions. This may have been due to an impurity noted in the starting material glucal, which appeared as an aldehyde-like peak that at first was thought to have been DMF in the 1 H NMR spectrum of the glucal 22. To overcome this, the trityl glucal $\mathbf{3}$ was subjected to four equivalents of $p$ azidobenzyl bromide to form the di-p-azidobenzyl protected 21 in 65\% yield (scheme 2.16). 
<smiles>OCC1OC=CC(O)[C@H]1O</smiles>

3

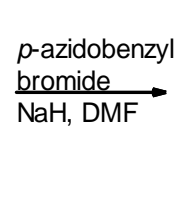

$\mathrm{N}_{3} \mathrm{PhH}_{2} \mathrm{CO}$

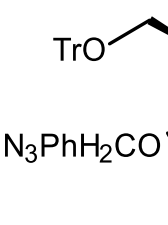

$\left.\right|_{\mathrm{OCH}_{2} \mathrm{PhN}_{3}} ^{\frac{\mathrm{CHCl} 3, \mathrm{NaOH}}{\mathrm{TEBAC}}}$

21


23

Formic acid diethyl ether

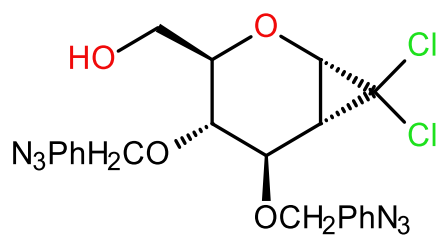

24

Scheme 2.16. Synthesis of 21, 23, and 24.

It is speculated that the p-azidobenzyl bromide was reacting with DMF to form the aldehyde species, this side compound could not be separated by means of column chromatography or recrystallization. Due to time constraints, at this stage of the project it was decided to ignore this byproduct and carry on with a somewhat impure compound 21. The cyclopropanation yielded only the major species, with the cyclopropane opposite the C-3 substituent with a yield of 15\%, consistent with previous cyclopropanations. It is likely that if the reaction had been high yielding a minor isomer would have also been seen. Subsequent removal of the trityl protecting group on $\mathrm{C} 6-\mathrm{OH}$ of 23 yielded $46 \%$ of pure alcohol 24 . Compound $\mathbf{2 4}$ was then attached to an alkyne-substituted sepharose matrix through Huisgen Cyclisation chemistry in a cell lysate (section 3.3.10). 


\subsubsection{Synthesis of Alkyne-substituted matrix; the probe}

To complement the synthesis of $\mathbf{2 4}$ an alkyne matrix was identified to allow the attachment of $\mathbf{2 4}$ via Huisgen Cyclisation. However, due to the cost of alkyne-substituted matrices, synthetic modifications of a standard epoxyactivated sepharose matrix was attempted. A small number of alkynes were added to the epoxide to determine which would be used for the Huisgen Cyclisation conditions. Propargyl alcohol could not be linked directly to the epoxide, probably due to the weakly nucleophilic hydroxyl group. It was decided that a stronger nucleophile was needed, a secondary amine would provide the greater nucleophilicity and would also not require the addition of a strong base. To achieve this, it was decided to couple an amine to propargyl bromide. Use of $\mathrm{N}$-propylamine and isopropylamine was attempted, but these amines were too volatile to give an acceptable yield of monopropargylated amine. 3Aminopropanol proved effective, resulting in 3-(prop-2ynylamino)propanol $\mathbf{3 7}$ in a yield of $85 \%$ along with $12 \%$ of the bis product 38. The addition of $\mathbf{3 7}$ to the epoxide-activated sepharose is covered in section 3.3.10.

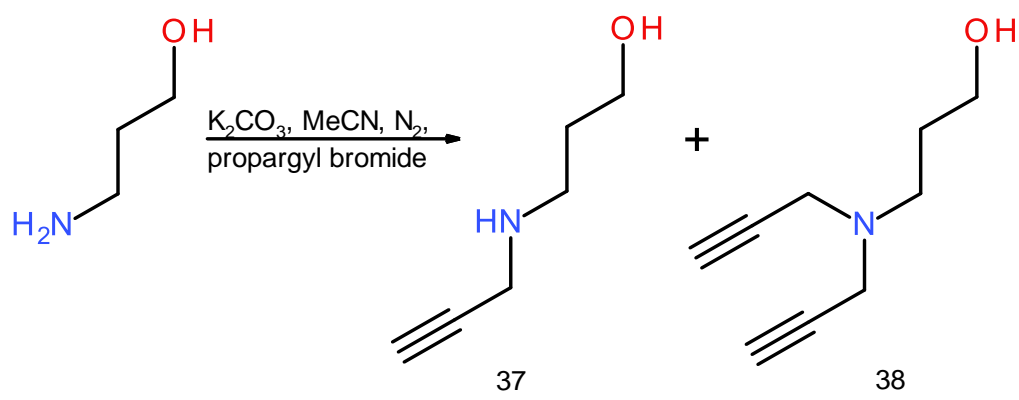

Scheme 2.17. Synthesis of $\mathbf{3 7}$ and $\mathbf{3 8}$ 


\subsection{Experimental}

Unless otherwise stated, the following conditions apply. All reactions were performed under an atmosphere of $\mathrm{N}_{2}$ in oven-dried glassware using HPLC grade solvents.

Reaction progress was monitored using thin layer chromatography (TLC) plates pre-coated with silica DC-Fertigfolien Polygram ${ }^{\circledR}$ SIL G/UV 254 and visualised by either UV radiation ( $254 \mathrm{~nm}$ ) or potassium permanganate dip. Purification by silica chromatography was conducted using a column filled with silica gel 60, with solvent systems indicated. $1 \mathrm{H} \mathrm{NMR}$ and ${ }^{13} \mathrm{C}$ NMR spectra were recorded on either a Varian Unity Inova $300(300 \mathrm{MHz}$ for ${ }^{1} \mathrm{H}$ and $75 \mathrm{MHz}$ for ${ }^{13} \mathrm{C}$ ), a 500 Varian Unity Inova $500\left(500 \mathrm{MHz}\right.$ for ${ }^{1} \mathrm{H}$ and $125 \mathrm{MHz}$ for ${ }^{13} \mathrm{C}$ ). All chemical shifts $(\delta)$ were referenced to solvent peaks $\left(7.26 \mathrm{ppm}{ }^{1} \mathrm{H}\right.$ - residual $\mathrm{CHCl}_{3}$ and $77.2 \mathrm{ppm}{ }^{13} \mathrm{C}-\mathrm{CDCl}_{3}$ or $4.80 \mathrm{ppm}$ $1 \mathrm{H}$ - residual $\mathrm{D}_{2} \mathrm{O}$. Infrared spectra were obtained on Bruker Tensor 27 FTIR spectrometer. High-resolution mass spectra were obtained on an Agilent Q-TOF LC/MS 6530 series. Optical rotations were recorded on a PerkinElmer 241 polarimeter in DMSO unless otherwise stated. 


\section{Tri-O-acetyl-D-glucal (1)}

Using a modification of Fischer \& Zach's procedure (Fischer \& Zach, 1912), acetic anhydride $(200 \mathrm{~mL}$ ) was added to a $500 \mathrm{~mL}$ flask, D-glucose (150 $\mathrm{mg}, 0.83 \mathrm{mmol}$ ) was dissolved under stirring, followed by drop-wise addition of perchloric acid. Further D-glucose (19 g, $0.105 \mathrm{~mol}$ ) was added slowly over $1.5 \mathrm{~h}$ at a rate such that the temperature of the reaction stayed between $40-50{ }^{\circ} \mathrm{C}$. Once the reaction was cooled to r.t., fuming hydrogen bromide in an acetic adic solution $(78 \mathrm{~mL}$ ) was added and left to stir for $1.5 \mathrm{~h}$ at r.t. The solution was diluted with dichloromethane (200 $\mathrm{mL})$, the organic layer was washed with water $(2 \times 100 \mathrm{~mL})$, then sat. sodium bicarbonate solution $(6 \times 80 \mathrm{~mL})$. The organic layers were combined and dried with magnesium sulphate, filtered and concentrated to afford an off white powder. Recrystallization from ethyl acetate/hexanes, provided (1) $(27.1 \mathrm{~g}, 93.1 \%)$ as a white solid. The spectral data matched those reported in the literature (Zhao et al. 2010)

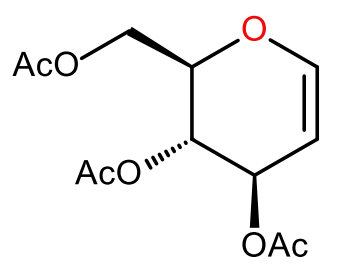

1) $R f=0.3 \quad(3: 1$ hexanes/ethyl acetate); $[\mathrm{a}]^{23.4}-8.26(\mathrm{C} 0.97, D M S O) ;$ m.p. $50-51^{\circ} \mathrm{C}$ (lit m.p. $=50-$

$\left.52^{\circ} \mathrm{C}\right) ;{ }^{1 H}$ NMR: $\left(500 \mathrm{MHz}, \mathrm{CDCl}_{3}\right) \delta 6.46$ (dd, $J=6.1,1.2$ $\mathrm{Hz}, 1 \mathrm{H}, \mathrm{H}-1), 5.33(\mathrm{~m}, 1 \mathrm{H}, \mathrm{H}-3), 5.22(\mathrm{dd}, J=7.5,5.6 \mathrm{~Hz}$, $1 \mathrm{H}, \mathrm{H}-4), 4.84$ (dd, J = 6.1, 3.2 Hz, $1 \mathrm{H} \mathrm{H}-2$ ), 4.39 (dd, J = 12.2, $5.9 \mathrm{~Hz}, 1 \mathrm{H}, \mathrm{H}-$ 6a) $, 4.25(\mathrm{~m}, 1 \mathrm{H}, \mathrm{H}-5), 4.19$ (dd, J = 12.2, $3.2 \mathrm{~Hz}, 1 \mathrm{H}, \mathrm{H}-6 \mathrm{~b}), 2.09$ (s, 3H, $\mathrm{CH}_{3} \mathrm{CO}$ ), 2.07 (s, 3H, CH $\left.3 \mathrm{CO}\right), 2.04$ (s, 3H, $\left.\mathrm{CH}_{3} \mathrm{CO}\right) ;{ }^{13} \mathrm{C} \mathrm{NMR}:(500 \mathrm{MHz}$, $\left.\mathrm{CDCl}_{3}\right) \delta 170.8\left(\mathrm{CH}_{3} \mathrm{CO}\right), 170.6\left(\mathrm{CH}_{3} \mathrm{CO}\right), 169.8\left(\mathrm{CH}_{3} \mathrm{CO}\right), 145.8(\mathrm{CH}, \mathrm{C}-1)$, $99.1(\mathrm{CH}, \mathrm{C}-2), 74.1(\mathrm{CH}, \mathrm{C}-5), 67.6(\mathrm{CH}, \mathrm{C}-3), 67.3(\mathrm{CH}, \mathrm{C}-4), 61.5\left(\mathrm{CH}_{2}, \mathrm{C}-\right.$ 6), $21.1\left(\mathrm{CH}_{3}, \mathrm{CH}_{3} \mathrm{CO}\right), 20.94\left(\mathrm{CH}_{3}, \mathrm{CH}_{3} \mathrm{CO}\right), 20.88\left(\mathrm{CH}_{3}, \mathrm{CH}_{3} \mathrm{CO}\right)$; IR (Film from $\mathrm{CH}_{2} \mathrm{Cl}_{2}$ ): $U_{\max } 2961,1738,1650,1369,1215,1032,912,730 \mathrm{~cm}^{-1}$. 


\section{D-Glucal (2)}

Solid sodium ( $62 \mathrm{mg}, 2.70 \mathrm{mmol}$ ) was reacted with methanol (50 mL), then treated with a solution of $1(2.32 \mathrm{~g}, 8.52 \mathrm{mmol})$ in methanol $(20 \mathrm{~mL})$. The reaction was stirred at r.t. for $10 \mathrm{~min}$, the solution was concentrated to provide crude D-glucal. The crude product was purified by successive addition of methanol $(3 \mathrm{~mL})$, acetone $(10 \mathrm{~mL})$ and diethyl ether $(20 \mathrm{~mL})$, which lead to precipitation of impurities. The solution was filtered and concentrated to afford $2(1.037 \mathrm{~g}, 84 \%)$ as a yellow solid/oil. The spectral data matched literature values (Moore, 2012).

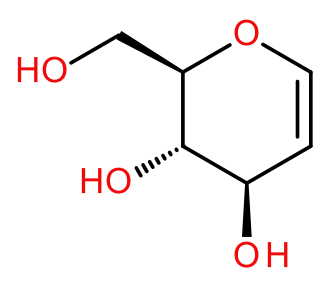

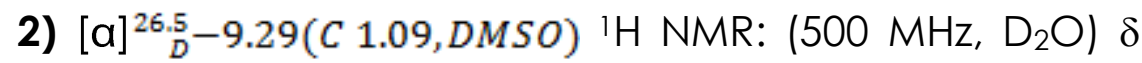
$6.41(\mathrm{dd}, J=6.1,1.6 \mathrm{~Hz}, 1 \mathrm{H}, \mathrm{H}-1$ ) , 4.82-4.81 (complex m, $3 \mathrm{H}, 3 \times \mathrm{OH}$ ), 4.80 (dd, J=6.1, $2.4 \mathrm{~Hz}, 1 \mathrm{H}, \mathrm{H}-2$ ), 4.23 (ddd, $J=7.0,2.3,1.7 \mathrm{~Hz}, 1 \mathrm{H}, \mathrm{H}-3$ ), 3.92-3.85 (complex m, 3H, $\mathrm{H}-5, \mathrm{H}-6 \mathrm{a}, \mathrm{H}-6 \mathrm{~b}), 3.67$ (dd, J = 9.0, 7.1 Hz, 1H, H-4); ${ }^{33} \mathrm{C} \mathrm{NMR:}\left(500 \mathrm{MHz}, \mathrm{D}_{2} \mathrm{O}\right)$ $\delta 143.6(\mathrm{CH}, \mathrm{C}-1), 102.7(\mathrm{CH}, \mathrm{C}-2), 78.1(\mathrm{CH}, \mathrm{C}-5), 68.7(\mathrm{CH}, \mathrm{C}-4), 68.2(\mathrm{CH}$, $\mathrm{C}-3), 60.0\left(\mathrm{CH}_{2}, \mathrm{C}-6\right) ; \mathrm{IR}(\mathrm{KBr}): \mathrm{U}_{\max } 3372,2887,1653,1416,1385,1232,1137$, $1098,1073,1045,1017 \mathrm{~cm}^{-1}$

\section{1,5-Anhydro-2-deoxy-6-O-trityl-D -arabino-hex-1-enitol (3)}

As reported by Esswein et al. (1990) 2 (1.81 g, $12.3 \mathrm{mmol})$ was added in a 1:1 mixture of dichloromethane and pyridine $(25 \mathrm{~mL})$ trityl chloride $(4.50 \mathrm{~g}$, $16.1 \mathrm{mmol}$ ) was then added over $3 \mathrm{~min}$ at room temperature. The solution was stirred for $18 \mathrm{~h}$ at r.t. before the solution was quenched with water, the resulting mixture was separated and the organic layer was washed with Sat. sodium bicarbonate solution $(2 \times 60 \mathrm{~mL})$, dried over magnesium sulphate and concentrated to provide a crude yellow oil. The crude oil was purified by column chromatography (hexanes/ethyl acetate 1:1) to afford 3 as a white solid in $3.82 \mathrm{~g}(80 \%)$ yield. The spectral data matched to what had previously been reported (Moore, 2012). 


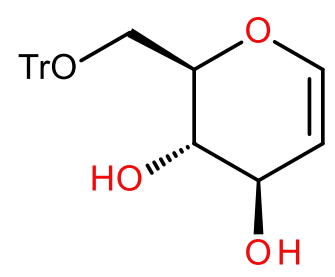

3) $\operatorname{Rf}=0.53 \quad(2: 1 \quad$ Ethyl acetate/hexanes); $[\mathrm{a}]_{D}^{25.4}+27.2(\mathrm{C} 1.00, \mathrm{DMSO})$; m.p. $61.0-63^{\circ} \mathrm{C}$ (lit m.p. $=62-$ $\left.64^{\circ} \mathrm{C}\right) ;{ }^{1} \mathrm{H}$ NMR $\left(500 \mathrm{MHz}, \mathrm{CDCl}_{3}\right): \delta 7.20-7.45(\mathrm{~m}, 15 \mathrm{H}$, Ph), 6.40 (dd, $J=6.1,1.6 \mathrm{~Hz}, 1 \mathrm{H}, \mathrm{H}-1$ ), 4.76 (dd, $J=6.1$, $2.2 \mathrm{~Hz}, 1 \mathrm{H}, \mathrm{H}-2), 4.24(\mathrm{~m}, 1 \mathrm{H}, \mathrm{H}-3), 3.9$ (ddd, $J=9.5,7.1$, $3.5 \mathrm{~Hz}, 1 \mathrm{H}, \mathrm{H}-4), 3.84$ (dt, J = 9.5, $3.4 \mathrm{~Hz}, 1 \mathrm{H}, \mathrm{H}-5$ ), 3.57 (dd, J = 10.4, $3.5 \mathrm{~Hz}$, $1 \mathrm{H}, \mathrm{H}-6 \mathrm{a}), 3.36$ (dd, J = 10.4, 3.5 Hz, 1H, H-6b), 2.33 (d, J=3.5 Hz, 1H, OH-4); ${ }^{13} \mathrm{C}$ NMR: $\left(\mathrm{CDCl}_{3}\right) \delta 144.7(\mathrm{CH}, \mathrm{C}-1), 143.6(\mathrm{C}, \mathrm{Ph}), 128.7(\mathrm{CH}, \mathrm{Ph}), 128.2(\mathrm{CH}$, $\mathrm{Ph}), 127.4(\mathrm{CH}, \mathrm{Ph}), 102.6(\mathrm{CH}, \mathrm{C}-2), 87.1\left(\mathrm{C}, \mathrm{CPh}_{3}\right), 76.7(\mathrm{CH}, \mathrm{C}-5), 71.8(\mathrm{CH}$, C-4), $69.6(\mathrm{CH}, \mathrm{C}-3), 63.0\left(\mathrm{CH}_{2}, \mathrm{C}-6\right)$; IR (Film from $\left.\mathrm{CH}_{2} \mathrm{Cl}_{2}\right)$ : U max 3382, 3061, 3033, 2920, 2882, 1647, 1491, 1449, 1229, 1099, 1056, 1032, 1002, 735, 702 $\mathrm{cm}^{-1}$

\section{1,5-Anhydro-3,4-di-O-benzyl-2-deoxy-6-O-trityl-D-arabino-hex-1-enitol (4)} In a slight modification of Esswein et al. (1990) procedure, 3 (0.440 g, 2.03 $\mathrm{mmol}$ ) was dissolved in dimethylformamide $(20 \mathrm{~mL})$ and cooled to $-10^{\circ} \mathrm{C}$ in an ice/salt bath. Sodium hydride $(0.671 \mathrm{~g}, 16.78 \mathrm{mmol})$ was added, portion-wise over $1 \mathrm{~min}$ and the solution stirred at $-10{ }^{\circ} \mathrm{C}$ for $15 \mathrm{~min}$ followed by addition of benzyl bromide $(0.712 \mathrm{~g}, 4.2 \mathrm{mmol})$. The solution was allowed to warm to room temperature and stirred for $16 \mathrm{~h}$. The reaction was then quenched with water $(20 \mathrm{~mL})$ and extracted with chloroform $(3 \times 25 \mathrm{~mL})$. The organic fractions were combined, dried over magnesium sulphate and concentrated to give the crude product as a pale yellow solid. The crude product was purified by column chromatography (hexanes/ethyl acetate 9:1) to afforded 4 as a white solid. The spectral data matched to what had previously been reported (Nagarajan et al. 1997 \& Moore, 2012).<smiles>OCC1OC=CC(O)[C@@H]1OCc1ccccc1</smiles>

5) $R f=0.40$ (9:1 hexanes/ethyl acetate); $115-117^{\circ} \mathrm{C}$ (lit m.p. $\left.=116^{\circ} \mathrm{C}\right) ; 1 \mathrm{H} \mathrm{NMR:}\left(500 \mathrm{MHz}, \mathrm{CDCl}_{3}\right) \delta 7.51-7.04$ (complex m, 25H, Ph), 6.52 (dd, J = 6.1, $1.5 \mathrm{~Hz}, 1 \mathrm{H}, \mathrm{H}-1$ ), 4.90 (dd, $J=6.1,2.4 \mathrm{~Hz}, 1 \mathrm{H}, \mathrm{H}-2), 4.76(\mathrm{~d}, J=11.0 \mathrm{~Hz}, 1 \mathrm{H}$, 
$\left.\mathrm{PhCH}_{2}\right), 4.65\left(\mathrm{~d}, J=11.6 \mathrm{~Hz}, 1 \mathrm{H}, \mathrm{PhCH}_{2}\right), 4.58\left(\mathrm{~d}, J=11.6 \mathrm{~Hz}, 1 \mathrm{H}, \mathrm{PhCH}_{2}\right)$, $4.53\left(\mathrm{~d}, J=11.0 \mathrm{~Hz}, 1 \mathrm{H}, \mathrm{PhCH}_{2}\right), 4.20(\mathrm{~m}, 1 \mathrm{H}, \mathrm{H}-3), 4.04(\mathrm{~m}, 1 \mathrm{H}, \mathrm{H}-5), 4.01$ (dd, $J=8.8,5.9 \mathrm{~Hz}, 1 \mathrm{H}, \mathrm{H}-4), 3.56(\mathrm{dd}, J=10.2,2.2 \mathrm{~Hz}, 1 \mathrm{H}, \mathrm{H}-6 \mathrm{a}), 3.43$ (dd, $J=$ 10.2, 4.1 Hz, $1 \mathrm{H}, \mathrm{H}-6 \mathrm{~b}) ;{ }^{13} \mathrm{C}$ NMR: $\left(\mathrm{CDCl}_{3}\right) \delta 145.0(\mathrm{CH}, \mathrm{C}-1), 144.0$ (C, Ph), 138.5 (C, Ph), 138.2 (C, Ph), $128.9(\mathrm{CH}, \mathrm{Ph}), 128.6(\mathrm{CH}, \mathrm{Ph}), 128.4(\mathrm{CH}, \mathrm{Ph})$, $128.1(\mathrm{CH}, \mathrm{Ph}), 127.96(\mathrm{CH}, \mathrm{Ph}), 127.94(\mathrm{CH}, \mathrm{Ph}), 127.8(\mathrm{CH}, \mathrm{Ph}), 127.7(\mathrm{CH}$, $\mathrm{Ph}), 127.1(\mathrm{CH}, \mathrm{Ph}), 99.9(\mathrm{CH}, \mathrm{C}-2), 86.6\left(\mathrm{C}, \mathrm{CPh}_{3}\right), 77.1(\mathrm{CH}, \mathrm{C}-5), 76.2(\mathrm{CH}$, C-3), $74.8(\mathrm{CH}, \mathrm{C}-4), 74.0\left(\mathrm{CH}_{2}, \mathrm{PhCH}_{2}\right), 71.0\left(\mathrm{CH}_{2}, \mathrm{PhCH}_{2}\right), 62.3\left(\mathrm{CH}_{2}, \mathrm{C}-6\right)$; IR (Film from $\mathrm{CH}_{2} \mathrm{Cl}_{2}$ ): U max 3061, 3031, 2927, 2878, 1647, 1491, 1449, 1095, $1066,1026,908,732,695 \mathrm{~cm}^{-1}$.

\section{1,5-Anhydro-4-O-benzyl-2-deoxy-6-O-trityl-D-arabino-hex-1-enitol (36)}

In a slight modification of Schmidt et al. procedure, $3(0.550 \mathrm{~g}, 4.1 \mathrm{mmol})$ was dissolved in dimethylformamide $(20 \mathrm{~mL})$ and cooled in an ice/salt bath to $-10{ }^{\circ} \mathrm{C}$. Sodium hydride $(0.169 \mathrm{~g}, 4.25 \mathrm{mmol})$ was added slowly, portion-wise over $1 \mathrm{~min}$ and the solution stirred at $-10{ }^{\circ} \mathrm{C}$ for $15 \mathrm{~min}$ followed by addition of benzyl bromide $(0.712 \mathrm{~g}, 4.21 \mathrm{mmol})$. The solution was allowed to warm to room temperature and stirred for $16 \mathrm{~h}$, followed by quenching with water $(20 \mathrm{~mL})$ and extraction with chloroform $(3 \times 25$ $\mathrm{mL}$ ). The organic fractions were combined, dried over magnesium sulphate and concentrated to give the crude product as a pale yellow solid. The crude product was purified by column chromatography (hexanes/ethyl acetate gradient elution 9:1 to 0:1) afforded $\mathbf{3 8}$ as a yellow oil (64\%). The spectral data matched to what had previously been reported (Moore, 2012).

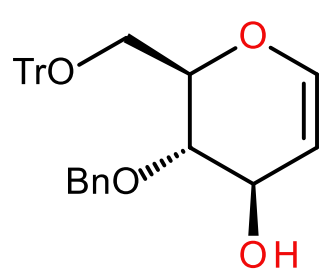

38) $\mathrm{Rf}=0.37$ (3:1 hexanes/ethyl acetate); 'H NMR: (500 MHz, $\mathrm{CDCl}_{3}$ ) $\delta$ 7.51-7.07 (complex $\mathrm{m}, 2 \mathrm{H}, \mathrm{Ph}$ ), $6.50(\mathrm{dd}, J=6.1,1.4 \mathrm{~Hz}, 1 \mathrm{H}, \mathrm{H}-1), 4.76$ (dd, $J=6.1,2.4$ $\mathrm{Hz}, 1 \mathrm{H}, \mathrm{H}-2), 4.62\left(\mathrm{~d}, J=11.5 \mathrm{~Hz}, 1 \mathrm{H}, \mathrm{PhCH}_{2}\right), 4.48(\mathrm{~d}, J=$ $\left.11.5 \mathrm{~Hz}, 1 \mathrm{H}, \mathrm{PhCH}_{2}\right), 4.31(\mathrm{~m}, 1 \mathrm{H}, \mathrm{H}-3), 3.95$ (apparent $\mathrm{dt}, J=9.3,2.9 \mathrm{~Hz}, 1 \mathrm{H}, \mathrm{H}-5), 4.82(\mathrm{dd}, J=9.3,6.6 \mathrm{~Hz}, 1 \mathrm{H}, \mathrm{H}-4), 3.65(\mathrm{dd}, J=$ 
10.3, 2.4 Hz, 1H, H-6a), 3.29 (dd, J = 10.3, 3.4 Hz, 1H, H-6b), 1.96 (bs, 1H, OH3); ${ }^{13} \mathrm{C} \mathrm{NMR:}\left(\mathrm{CDCl}_{3}\right) \delta 144.9$ (CH, C-1), 143.9 (C, Ph), 138.3 (C, Ph), 128.9 $(\mathrm{CH}, \mathrm{Ph}), 128.6(\mathrm{CH}, \mathrm{Ph}), 128.1(\mathrm{CH}, \mathrm{Ph}), 127.99(\mathrm{CH}, \mathrm{Ph}), 127.97(\mathrm{CH}, \mathrm{Ph})$, $127.2(\mathrm{CH}, \mathrm{Ph}), 102.5(\mathrm{CH}, \mathrm{C}-2), 86.6\left(\mathrm{C}, \mathrm{CPh}_{3}\right), 77.5(\mathrm{CH}, \mathrm{C}-4), 77.0(\mathrm{CH}, \mathrm{C}-$ 5), $74.0\left(\mathrm{CH}_{2}, \mathrm{PhCH}_{2}\right), 69.4(\mathrm{CH}, \mathrm{C}-3), 62.3\left(\mathrm{CH}_{2}, \mathrm{C}-6\right)$; IR (Film from $\left.\mathrm{CH}_{2} \mathrm{Cl}_{2}\right)$ : $U_{\max } 3372,3061,3030,2927,2879,1650,1492,1449,1091,1029,1001,901$, $744,696 \mathrm{~cm}^{-1}$.

\section{1,5-Anhydro-3,4-di-O-benzyl-6-O-(triphenylcarbinyl)-2-deoxy-1,2-C-} (dichloromethylene)-D-glycero-D-gulo-hexitol (5) and 1,5-anhydro-3,4-diO-benzyl-6-O-(triphenylcarbinyl)-2-deoxy-1,2-C-(dichloromethylene)-Dglycero-D-talo-hexitol (6)

As reported by Nagarajan et al. (1997), a solution of 4 (800 mg, $1.93 \mathrm{mmol}$ ) and benzyltriethylammonium chloride $(10 \mathrm{mg}, 0.044 \mathrm{mmol}$ ) in chloroform $(5 \mathrm{~mL})$ was treated drop-wise with $33 \%$ sodium hydroxide $(10 \mathrm{~mL})$ with rapid stirring. The biphasic mixture was stirred at r.t for $10 \mathrm{hrs}$. The biphasic mixture was then diluted with water $(10 \mathrm{~mL})$ and extracted with dichloromethane $(3 \times 20 \mathrm{~mL})$. The organic fractions were combined and dried over magnesium sulphate and concentrated to provide a crude mixture of cyclopropanes 5 and $\mathbf{6}$. The crude product was purified by column chromatography (14:1 hexanes: ethyl acetate) liberated the major cyclopropane 5 as a white solid in a yield of $626 \mathrm{mg} \mathrm{(62 \% )} \mathrm{and} \mathrm{the}$ minor cyclopropane 6 as an oil in a yield of $151 \mathrm{mg}(15 \%)$ The spectral data matched those previously reported (Nagarajan et al. 1997 \& Moore, 2012).

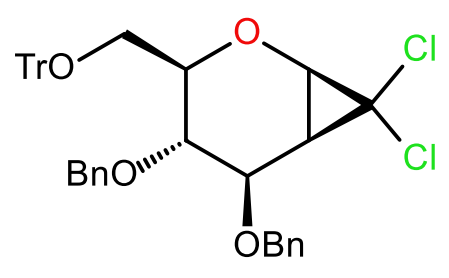

5) $R f=0.40$ (9:1 hexanes/ethyl acetate); m.p. 50.0-51.0 ${ }^{\circ} \mathrm{C}$; $1 \mathrm{H}$ NMR: $\left(500 \mathrm{MHz}, \mathrm{CDCl}_{3}\right) \delta 7.47-$ 7.22 (complex m, 25H, Ph), 4.81 (d, $J=11.6 \mathrm{~Hz}, 1 \mathrm{H}$, $\mathrm{PhCH}_{2}$ ), 4.80 (d, J=10.7 Hz, $\left.1 \mathrm{H}, \mathrm{PhCH}_{2}\right), 4.70$ (d, J $\left.=11.6 \mathrm{~Hz}, 1 \mathrm{H}, \mathrm{PhCH}_{2}\right), 4.25(\mathrm{~d}, J=10.7 \mathrm{~Hz}, 1 \mathrm{H}$,

$\mathrm{PhCH}_{2}$ ), $4.06(\mathrm{~d}, J=8.0 \mathrm{~Hz}, 1 \mathrm{H}, \mathrm{H}-1), 3.88-3.84$ (complex m, 2H H-4, H-5), 
$3.78(\mathrm{dd}, J=8.8,4.9 \mathrm{~Hz}, 1 \mathrm{H}, \mathrm{H}-3), 3.48(\mathrm{dd}, J=10.2,3.0 \mathrm{~Hz}, 1 \mathrm{H}, \mathrm{H}-6 \mathrm{a}), 3.17$ (dd, $J=10.2,3.0 \mathrm{~Hz}, 1 \mathrm{H}, \mathrm{H}-6 \mathrm{~b}$ ), 1.87 (dd, J = 8.0, $4.9 \mathrm{~Hz}, 1 \mathrm{H}, \mathrm{H}-2$ ); ${ }^{13} \mathrm{C}$ NMR: $\left(\mathrm{CDCl}_{3}\right) \delta 143.8$ (C, Ph), 138.1 (C, Ph), 137.7 (C, Ph), 128.8 (CH, Ph), 128.7 $(\mathrm{CH}, \mathrm{Ph}), 128.4(\mathrm{CH}, \mathrm{Ph}), 128.11(\mathrm{CH}, \mathrm{Ph}), 128.10(\mathrm{CH}, \mathrm{Ph}), 128.08(\mathrm{CH}, \mathrm{Ph})$, $128.06(\mathrm{CH}, \mathrm{Ph}), 127.8(\mathrm{CH}, \mathrm{Ph}), 127.3(\mathrm{CH}, \mathrm{Ph}), 86.9\left(\mathrm{C}, \mathrm{CPh}_{3}\right), 80.5(\mathrm{CH}, \mathrm{C}-$ 5), $77.6(\mathrm{CH}, \mathrm{C}-3), 75.9(\mathrm{CH}, \mathrm{C}-4), 75.0\left(\mathrm{CH}_{2}, \mathrm{PhCH}_{2}\right), 72.2\left(\mathrm{CH}_{2}, \mathrm{PhCH}_{2}\right)$, $63.7\left(\mathrm{CH}_{2}, \mathrm{C}-6\right), 61.8(\mathrm{C}, \mathrm{C}-7), 59.3(\mathrm{CH}, \mathrm{C}-1), 34.7(\mathrm{CH}, \mathrm{C}-2)$; IR (Film from $\mathrm{CH}_{2} \mathrm{Cl}_{2}$ ): Umax $3087,3061,3031,2919,2869,1492,1449,1158,1093,1029,736$, $698 \mathrm{~cm}^{-1}$.

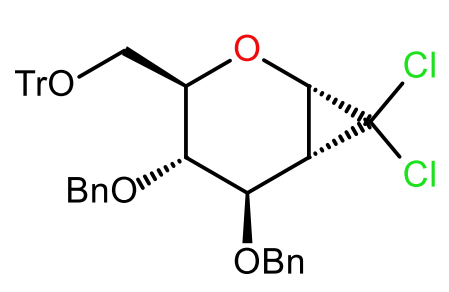

6) $R f=0.30(9: 1$ hexanes/ethyl acetate $)$; m.p. 50$51{ }^{\circ} \mathrm{C} ; 1 \mathrm{H}$ NMR: (500 MHz, $\left.\mathrm{CDCl}_{3}\right) \delta 7.51-7.17$ (complex $\mathrm{m}, 23 \mathrm{H}, \mathrm{Ph}$ ), 6.90-6.88 (complex $\mathrm{m}, 2 \mathrm{H}$, $\mathrm{Ph}), 4.88\left(\mathrm{~d}, J=11.9 \mathrm{~Hz}, 1 \mathrm{H}, \mathrm{PhCH}_{2}\right), 4.75(\mathrm{~d}, J=$ $\left.11.9 \mathrm{~Hz}, 1 \mathrm{H}, \mathrm{PhCH}_{2}\right), 4.70(\mathrm{~d}, J=10.6 \mathrm{~Hz}, 1 \mathrm{H}$,

$\mathrm{PhCH}_{2}$ ), 4.34 (d, J = 10.6 Hz, 1H, PhCH $)^{2}, 4.14-4.08$ (complex m, 2H, H-3, H4), $4.05(\mathrm{~d}, J=8.0 \mathrm{~Hz}, 1 \mathrm{H}, \mathrm{H}-1), 3.56(\mathrm{dd}, J=10.3,2.0 \mathrm{~Hz}, 1 \mathrm{H}, \mathrm{H}-6 \mathrm{a}), 3.41$ (ddd, $J=9.7,3.9,2.0 \mathrm{~Hz}, 1 \mathrm{H}, \mathrm{H}-5$ ), 3.19 (dd, $J=10.3,3.9 \mathrm{~Hz}, 1 \mathrm{H}, \mathrm{H}-6 \mathrm{~b}), 2.12$ (apparent $\mathrm{t}, \mathrm{J}=7.7 \mathrm{~Hz}, 1 \mathrm{H}, \mathrm{H}-2$ ); ${ }^{13} \mathrm{C} \mathrm{NMR:}\left(\mathrm{CDCl}_{3}\right) \delta 144.0$ (C, Ph), 138.3 (C, $\mathrm{Ph}), 138.0$ (C, Ph), $129.0(\mathrm{CH}, \mathrm{Ph}), 128.7(\mathrm{CH}, \mathrm{Ph}), 128.3(\mathrm{CH}, \mathrm{Ph}), 128.2(\mathrm{CH}$, $\mathrm{Ph}), 128.09(\mathrm{CH}, \mathrm{Ph}), 128.08(\mathrm{CH}, \mathrm{Ph}), 128.0(\mathrm{CH}, \mathrm{Ph}), 127.9(\mathrm{CH}, \mathrm{Ph}), 127.0$ $(\mathrm{CH}, \mathrm{Ph}), 86.7\left(\mathrm{C}, \mathrm{CPh}_{3}\right), 78.4(\mathrm{CH}, \mathrm{C}-5), 78.2(\mathrm{CH}, \mathrm{C}-4), 76.6(\mathrm{CH}, \mathrm{C}-3), 74.9$ $\left(\mathrm{CH}_{2}, \mathrm{PhCH}_{2}\right), 71.6\left(\mathrm{CH}_{2}, \mathrm{PhCH}_{2}\right), 62.33\left(\mathrm{CH}_{2}, \mathrm{C}-6\right), 62.25(\mathrm{CH}, \mathrm{C}-1), 62.1(\mathrm{C}$, C-7), 33.1 (CH, C-2); IR (Film from $\mathrm{CH}_{2} \mathrm{Cl}_{2}$ ): U $\mathrm{U}_{\max } 3061,3031,2930,2875,1492$, $1449,1182,1090,1023,910,736,698 \mathrm{~cm}^{-1}$.

1,5-Anhydro-3,4-di-O-benzyl-2-deoxy-1,2-C-(dichloromethylene)-Dglycero-D-gulo-hexitol (7), and 1,5-anhydro-3,4-di-O-benzyl-6-O-(formyl)2-deoxy-1,2-C-(dichloromethylene)- D-glycero-D-gulo-hexitol (8)

A solution of 5 (50 mg, $0.09 \mathrm{mmol})$ in diethyl ether $(0.3 \mathrm{~mL})$ was treated with formic acid $(0.4 \mathrm{~mL})$ and stirred at room temperature for $1 \mathrm{~h}$. The 
reaction was diluted with diethyl ether ( $4 \mathrm{~mL}$ ) and washed with sat. sodium bicarbonate solution (4 × $10 \mathrm{~mL})$. The organic layer was dried over magnesium sulphate and concentrated. The crude product was purified by column chromatography (hexanes/ethyl acetate gradient 14:1 to 5:1) to give 7 in a yeild of $16.56 \mathrm{mg} \mathrm{(45 \% )}$ as a white solid and 8 in a yeild of $8.65 \mathrm{mg}(22 \%)$ as an oil. The spectral data matched reported (Moore 20012).

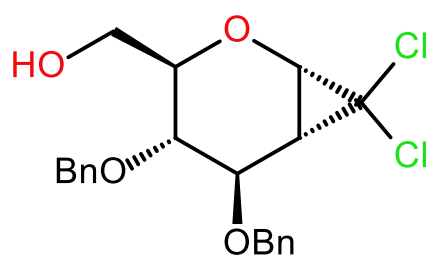

7) $R f=0.45 \quad(3: 1$ hexanes/ethyl acetate $)$; $[\mathrm{a}]_{D}^{25.4}+63.2$ (C 1.00,DMSO); m.p. $80.0-81{ }^{\circ} \mathrm{C} ; \quad \mathrm{H}$ NMR: $\left(500 \mathrm{MHz}, \mathrm{CDCl}_{3}\right.$ ) $\delta$ 7.43-7.29 (complex m, $10 \mathrm{H}, \mathrm{Ph}), 4.93\left(\mathrm{~d}, J=11.2 \mathrm{~Hz}, 1 \mathrm{H}, \mathrm{PhCH}_{2}\right), 4.81$ (d, J $\left.=11.7 \mathrm{~Hz}, 1 \mathrm{H}, \mathrm{PhCH}_{2}\right), 4.72(\mathrm{~d}, J=11.7 \mathrm{~Hz}, 1 \mathrm{H}$, $\mathrm{PhCH}_{2}$ ), $4.67\left(\mathrm{~d}, J=11.2 \mathrm{~Hz}, 1 \mathrm{H}, \mathrm{PhCH}_{2}\right), 3.87(\mathrm{~d}, J=8.3 \mathrm{~Hz}, 1 \mathrm{H}, \mathrm{H}-1), 3.81$ $(\mathrm{dd}, J=9.5,3.9 \mathrm{~Hz}, 1 \mathrm{H}, \mathrm{H}-3), 3.87(\mathrm{dt}, J=8.6,3.9 \mathrm{~Hz}, 1 \mathrm{H}, \mathrm{H}-5), 3.68(\mathrm{~d}, J=3.9$, $2 \mathrm{H}, \mathrm{H}-6 \mathrm{a}, \mathrm{b}), 3.60(\mathrm{dd}, J=9.5,8.6 \mathrm{~Hz}, 1 \mathrm{H}, \mathrm{H}-4), 1.84(\mathrm{dd}, J=8.6,3.9 \mathrm{~Hz}, 1 \mathrm{H}, \mathrm{H}-$ 2), $1.68(\mathrm{~s}, 1 \mathrm{H}, 6-\mathrm{OH}) ;{ }^{13} \mathrm{C}$ NMR: $\left(\mathrm{CDCl}_{3}\right) \delta 138.1$ (C, Ph), 137.6 (C, Ph), 128.7 $(\mathrm{CH}, \mathrm{Ph}), 128.6(\mathrm{CH}, \mathrm{Ph}), 128.3(\mathrm{CH}, \mathrm{Ph}), 128.15(\mathrm{CH}, \mathrm{Ph}), 128.12(\mathrm{CH}, \mathrm{Ph})$, $79.6(\mathrm{CH}, \mathrm{C}-5), 77.2(\mathrm{CH}, \mathrm{C}-3), 75.0\left(\mathrm{CH}_{2}, \mathrm{PhCH}_{2}\right), 74.8(\mathrm{CH}, \mathrm{C}-4), 72.2\left(\mathrm{CH}_{2}\right.$, $\left.\mathrm{PhCH}_{2}\right), 62.8\left(\mathrm{CH}_{2}, \mathrm{C}-6\right), 60.9$ (C, C-7), $58.9(\mathrm{CH}, \mathrm{C}-1), 33.9$ (CH, C-2); IR (Film from $\mathrm{CH}_{2} \mathrm{Cl}_{2}$ ): $u_{\max } 3375,3032,2976,2864,1496,1454,1365,1095,1026,733$, $696 \mathrm{~cm}^{-1}$.

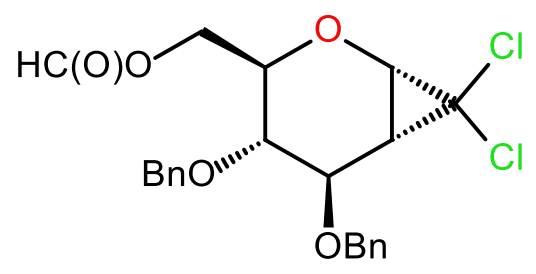

8) $R f=0.30(9: 1$ hexanes/ethyl acetate $) ; 1 \mathrm{H}$ NMR: $\left(500 \mathrm{MHz}, \mathrm{CDCl}_{3}\right) \delta 8.03(q, J=0.7 \mathrm{~Hz}$, $1 \mathrm{H}, \mathrm{HC}(\mathrm{O}) \mathrm{O}$ ), 7.43-7.27 (complex $\mathrm{m}, 10 \mathrm{H}$, $\mathrm{Ph}), 4.95\left(\mathrm{~d}, J=11.2 \mathrm{~Hz}, 1 \mathrm{H}, \mathrm{PhCH}_{2}\right), 4.81$ (d, J $\left.=11.3 \mathrm{~Hz}, 1 \mathrm{H}, \mathrm{PhCH}_{2}\right), 4.70(\mathrm{~d}, J=11.3 \mathrm{~Hz}, 1 \mathrm{H}$, $\left.\mathrm{PhCH}_{2}\right), 4.63\left(\mathrm{~d}, J=11.2 \mathrm{~Hz}, 1 \mathrm{H}, \mathrm{PhCH}_{2}\right), 4.30 \mathrm{ddd}, J=12.0,5.1,0.7,1 \mathrm{H}, \mathrm{H}-$ 6a), 4.15 (ddd, $J=12.0,2.7,0.7,1 \mathrm{H}, \mathrm{H}-6 \mathrm{~b}$ ), 3.87 (dddd, $J=8.3,5.1,2.7,0.7$ $\mathrm{Hz}, 1 \mathrm{H}, \mathrm{H}-5), 3.86(\mathrm{~d}, J=8.1 \mathrm{~Hz}, 1 \mathrm{H}, \mathrm{H}-1), 3.80(\mathrm{dd}, J=9.5,4.4 \mathrm{~Hz}, 1 \mathrm{H}, \mathrm{H}-3)$, $3.57(\mathrm{dd}, J=9.5,8.3 \mathrm{~Hz}, 1 \mathrm{H}, \mathrm{H}-4), 1.82$ (dd, $J=8.1,4.4 \mathrm{~Hz}, 1 \mathrm{H}, \mathrm{H}-2) ;{ }^{3} \mathrm{C}$ NMR: $\left(\mathrm{CDCl}_{3}\right) \delta 160.6(\mathrm{C}, \mathrm{CHO}), 137.7$ (C, Ph), 137.5 (C, Ph), $105128.73(\mathrm{CH}, \mathrm{Ph})$, 
$128.66(\mathrm{CH}, \mathrm{Ph}), 128.5(\mathrm{CH}, \mathrm{Ph}), 128.2(\mathrm{CH}, \mathrm{Ph}), 128.13(\mathrm{CH}, \mathrm{Ph}), 128.08(\mathrm{CH}$, $\mathrm{Ph}), 77.9(\mathrm{CH}, \mathrm{C}-5), 77.2(\mathrm{CH}, \mathrm{C}-3), 74.9\left(\mathrm{CH}_{2}, \mathrm{PhCH}_{2}\right), 74.5(\mathrm{CH}, \mathrm{C}-4), 72.1$ $\left(\mathrm{CH}_{2}, \mathrm{PhCH}_{2}\right), 63.3\left(\mathrm{CH}_{2}, \mathrm{C}-6\right), 61.0(\mathrm{C}, \mathrm{C}-7), 58.6(\mathrm{CH}, \mathrm{C}-1), 34.1(\mathrm{CH}, \mathrm{C}-2)$; IR (Film from $\mathrm{CH}_{2} \mathrm{Cl}_{2}$ ): U $U_{\max } 3062,3031,2919,2869,1726,1496,1453,1152$, $1128,1089,1027,735,697 \mathrm{~cm}^{-1}$.

\section{1,5-Anhydro-3,4-di-O-benzyl-2-deoxy-1,2-C-(dichloromethylene)-} Dglycero-D-gulo-hexitol (9), and1,5-anhydro-3,4-di-O-benzyl-6-O-(formyl)2-deoxy-1,2-C-(dichloromethylene)-D-glycero-D-talo-hexitol (10)

A solution of 6 (50 $\mathrm{mg}, 0.09 \mathrm{mmol})$ in diethyl ether $(0.3 \mathrm{~mL})$ was treated with formic acid $(0.4 \mathrm{~mL})$ and stirred at r.t. for $10 \mathrm{~h}$. The mixture was diluted with diethyl ether $(4 \mathrm{~mL})$ and washed with saturated sodium bicarbonate solution $(4 \times 10 \mathrm{~mL})$. The organic layer was dried over magnesium sulphate and concentrated. The crude product was purified by column chromatography (hexanes/ethyl acetate gradient 14:1 to 5:1) to give 19 in a yield of $17 \mathrm{mg} \mathrm{(30 \% )}$ of 9 a colourless oil and $5 \mathrm{mg}(9 \%)$ of 10 as a yellow oil. The spectral data matched to what had previously been reported (Moore 2012).

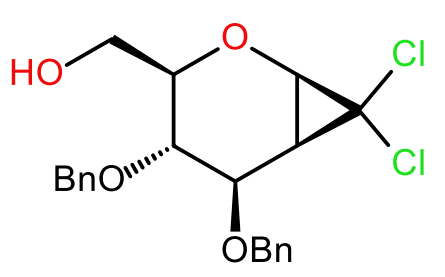

9) $R f=0.38$ (3:1 hexanes/ethyl acetate); 'H NMR: (500 MHz, $\mathrm{CDCl}_{3}$ ) $\delta$ 7.43-7.23 (complex $\mathrm{m}, 10 \mathrm{H}$, $\mathrm{Ph}), 4.81\left(\mathrm{~d}, J=11.2 \mathrm{~Hz}, 1 \mathrm{H}, \mathrm{PhCH}_{2}\right), 4.78(\mathrm{~d}, J=$ $\left.11.7 \mathrm{~Hz}, 1 \mathrm{H}, \mathrm{PhCH}_{2}\right), 4.72(\mathrm{~d}, J=11.7 \mathrm{~Hz}, 1 \mathrm{H}$, $\left.\mathrm{PhCH}_{2}\right), 4.67\left(\mathrm{~d}, J=11.2 \mathrm{~Hz}, 1 \mathrm{H}, \mathrm{PhCH}_{2}\right), 4.05(\mathrm{~d}, J=8.3 \mathrm{~Hz}, 1 \mathrm{H}, \mathrm{H}-3), 3.80$ (t, $J=9.4 \mathrm{~Hz}, 1 \mathrm{H}, \mathrm{H}-1), 3.59(\mathrm{dt}, J=8.6,3.9 \mathrm{~Hz}, 1 \mathrm{H}, \mathrm{H}-5), 3.78(\mathrm{~d}, J=3.9,2 \mathrm{H}, \mathrm{H}-$ $6 a, b), 3.58(d d, J=9.5,8.6 \mathrm{~Hz}, 1 \mathrm{H}, \mathrm{H}-4), 2.11(t, J=8.2 \mathrm{~Hz}, 1 \mathrm{H}, \mathrm{H}-2) ;{ }^{13} \mathrm{C}$ NMR: $\left(\mathrm{CDCl}_{3}\right) \delta 140.1$ (C, Ph), $137.6(\mathrm{C}, \mathrm{Ph}), 128.9(\mathrm{CH}, \mathrm{Ph}), 128.6(\mathrm{CH}, \mathrm{Ph}), 128.3$ $(\mathrm{CH}, \mathrm{Ph}), 128.2(\mathrm{CH}, \mathrm{Ph}), 128.2(\mathrm{CH}, \mathrm{Ph}), 79.7(\mathrm{CH}, \mathrm{C}-5), 77.4(\mathrm{CH}, \mathrm{C}-3), 75.0$ $\left(\mathrm{CH}_{2}, \mathrm{PhCH}_{2}\right), 75.1(\mathrm{CH}, \mathrm{C}-4), 72.2\left(\mathrm{CH}_{2}, \mathrm{PhCH}_{2}\right), 62.9\left(\mathrm{CH}_{2}, \mathrm{C}-6\right), 60.9(\mathrm{C}$, C-7), $60.0(\mathrm{CH}, \mathrm{C}-1), 33.1$ (CH, C-2). IR (Film from $\mathrm{CH}_{2} \mathrm{Cl}_{2}$ ): U max 3378, 3033, $2979,2862,1494,1454,1365,1098,1030,736,697 \mathrm{~cm}^{-1}$. 


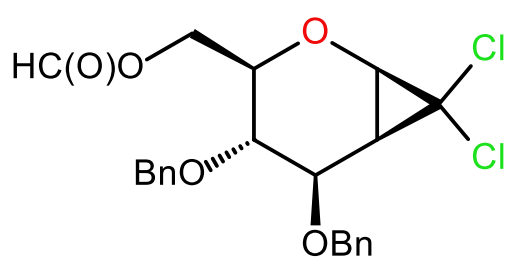

10) $R f=0.25$ (9:1 hexanes/ethyl acetate); ${ }^{1} \mathrm{H}$ NMR: $\left(500 \mathrm{MHz}, \mathrm{CDCl}_{3}\right) \delta 8.0(\mathrm{~s}, 1 \mathrm{H}, \mathrm{HC}(\mathrm{O}) \mathrm{O})$, 7.42-7.23 (complex $\mathrm{m}, 10 \mathrm{H}, \mathrm{Ph}$ ), 4.88 (d, $\mathrm{J}=$ $\left.11.8 \mathrm{~Hz}, 1 \mathrm{H}, \mathrm{PhCH}_{2}\right), 4.85(\mathrm{~d}, J=11.0 \mathrm{~Hz}, 1 \mathrm{H}$,

$\left.\mathrm{PhCH}_{2}\right), 4.70\left(\mathrm{~d}, J=11.8 \mathrm{~Hz}, 1 \mathrm{H}, \mathrm{PhCH}_{2}\right), 4.57\left(\mathrm{~d}, J=11.0 \mathrm{~Hz}, 1 \mathrm{H}, \mathrm{PhCH}_{2}\right), 4.47$ (dd, $J=12.0,1.2 \mathrm{~Hz}, 1 \mathrm{H}, \mathrm{H}-6 \mathrm{a}), 4.22$ (dd, $J=12.0,5.1 \mathrm{~Hz}, 1 \mathrm{H}, \mathrm{H}-6 \mathrm{~b}), 4.19$ (apparent $\mathrm{t}, J=7.8 \mathrm{~Hz}, 1 \mathrm{H}, \mathrm{H}-3), 3.96(\mathrm{~d}, J=8.1 \mathrm{~Hz}, 1 \mathrm{H}, \mathrm{H}-1), 3.80(\mathrm{dd}, J=$ $10.4,7.6 \mathrm{~Hz}, 1 \mathrm{H}, \mathrm{H}-4), 3.50$ (ddd, $J=10.4,5.1,1.7 \mathrm{~Hz}, 1 \mathrm{H}, \mathrm{H}-5), 2.12(t, J=8.1$ $\mathrm{Hz}, 1 \mathrm{H}, \mathrm{H}-2) ;{ }^{13} \mathrm{C} \mathrm{NMR:}\left(\mathrm{CDCl}_{3}\right) \delta 160.7$ (C, $\left.\mathrm{COH}\right), 137.8$ (C, Ph), 137.7 (C, Ph), $128.8(\mathrm{CH}, \mathrm{Ph}), 128.6(\mathrm{CH}, \mathrm{Ph}), 128.24(\mathrm{CH}, \mathrm{Ph}), 128.19(\mathrm{CH}, \mathrm{Ph}), 128.18(\mathrm{CH}$, $\mathrm{Ph}), 128.1(\mathrm{CH}, \mathrm{Ph}), 77.9(\mathrm{CH}, \mathrm{C}-3), 76.2(\mathrm{CH}, \mathrm{C}-5), 75.9\left(\mathrm{CH}, \mathrm{C}-4,74.7\left(\mathrm{CH}_{2}\right.\right.$, $\left.\mathrm{PhCH}_{2}\right), 71.3\left(\mathrm{CH}_{2}, \mathrm{PhCH}_{2}\right), 62.5\left(\mathrm{CH}_{2}, \mathrm{C}-6\right), 62.2(\mathrm{CH}, \mathrm{C}-1), 61.4(\mathrm{C}, \mathrm{C}-7)$, 32.8 (C, C-2); IR (Film from $\mathrm{CH}_{2} \mathrm{Cl}_{2}$ ): U $\max 3065,3031,2918,2870,1724,1497$, $1454,1170,1088,1027,734,698 \mathrm{~cm}^{-1}$.

\section{1,5-Anhydro-3,4-di-O-benzyl-2-deoxy-1,2-C-(chloromethylene)-D- glycero-D-gulo-hexitol (11),}

To a solution of 7 (40 mg, $0.10 \mathrm{mmol}$ ) in tetrahydrofuran $(1 \mathrm{~mL}$ ) was added lithium aluminium hydride (11.2 mg, $0.29 \mathrm{mmol})$ and stirred at r.t. under nitrogen for 3 days. The mixture was quenched with water $(2 \mathrm{~mL})$, extracted with ethyl acetate $(3 \times 5 \mathrm{~mL})$. The combined organic layers were dried over magnesium sulphate and concentrated. The crude product was purified by column chromatography (hexanes/ethyl acetate 4:1) to give 11 in a yield of $19 \mathrm{mg}(47.4 \%)$ as an oil.

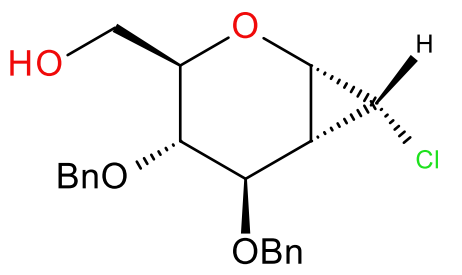

11) $R f=0.40$ (3:1 hexanes/ethyl acetate) 'H NMR: (500 MHz, $\mathrm{CDCl}_{3}$ ) $\delta$ 7.42-7.30 (complex $\mathrm{m}, 10 \mathrm{H}$, $\mathrm{Ph}), 4.79\left(\mathrm{~d}, J=11.4 \mathrm{~Hz}, 1 \mathrm{H}, \mathrm{PhCH}_{2}\right), 4.79$ (d, J = $\left.11.7 \mathrm{~Hz}, 1 \mathrm{H}, \mathrm{PhCH}_{2}\right), 4.68(\mathrm{~d}, J=11.5 \mathrm{~Hz}, 2 \mathrm{H}$, $\left.\mathrm{PhCH}_{2}\right), 3.92(\mathrm{dd}, \mathrm{J}=9.6,4.4 \mathrm{~Hz}, 1 \mathrm{H}, \mathrm{H}-1), 3.81(\mathrm{~m}$,

$1 \mathrm{H}, \mathrm{H}-3), 3.72(\mathrm{~m}, 1 \mathrm{H}, \mathrm{H}-5), 3.69-3.60(\mathrm{~m}, 3 \mathrm{H}, \mathrm{H}-4, \mathrm{H}-6 \mathrm{a}, \mathrm{b}), 3.15$ (dd, $J=5.1$, $3.2 \mathrm{~Hz}, 1 \mathrm{H}, \mathrm{H}-2), 1.83(\mathrm{t}, \mathrm{J}=6.3 \mathrm{~Hz}, 1 \mathrm{H}, \mathrm{OH}), 1.37-1.33(\mathrm{~m}, 1 \mathrm{H}, \mathrm{H}-8) ;{ }^{33} \mathrm{C}$ NMR: 
$\left(\mathrm{CDCl}_{3}\right) \delta(\mathrm{C}, \mathrm{Ph}),(\mathrm{C}, \mathrm{Ph}),(\mathrm{CH}, \mathrm{Ph}),(\mathrm{CH}, \mathrm{Ph}),(\mathrm{CH}, \mathrm{Ph}),(\mathrm{CH}, \mathrm{Ph}),(\mathrm{CH}, \mathrm{Ph})$, $(\mathrm{CH}, \mathrm{C}-5),(\mathrm{CH}, \mathrm{C}-3),\left(\mathrm{CH}_{2}, \mathrm{PhCH}_{2}\right),(\mathrm{CH}, \mathrm{C}-4),\left(\mathrm{CH}_{2}, \mathrm{PhCH}_{2}\right),\left(\mathrm{CH}_{2}, \mathrm{C}-6\right)$, (C, C-7), (CH, C-1), (CH, C-2) IR (Film from $\mathrm{CH}_{2} \mathrm{Cl}_{3}$ ): U max 3370, 3042, 2972, $2864,1499,1456,1369,1092,1027,732,696 \mathrm{~cm}^{-1} ; \mathrm{C}_{21} \mathrm{H}_{23} \mathrm{ClO}_{4} \mathrm{Na}^{+}[\mathrm{M}+\mathrm{Na}]^{+}$ calculated 374.1285 , found 374.1353 .

\section{1,5-anhydro-3,4-di-O-benzyl-6-O-(carboxyl)-2-deoxy-1,2-C (dichloromethylene)- D-glycero-D-gulo-hexitol (12)}

Dimethyl sulfoxide $(86.17 \mathrm{mg}, 1.103 \mathrm{mmol})$ and dichloromethane $(3 \mathrm{~mL})$, was cooled to $-78{ }^{\circ} \mathrm{C}$. Oxalyl chloride $(69.9 \mathrm{mg}, 0.551 \mathrm{mmol}$ ) was then added and stirred for $40 \mathrm{~min}$ before 7 (150 $\mathrm{mg}, 0.362 \mathrm{mmol}$ ) was added and stirred for another $30 \mathrm{~min}$ before triethylamine $(22.34 \mathrm{mg}, 2.208 \mathrm{mmol}$ ) was added, stirred for another $30 \mathrm{~min}$, quenched with Sat. sodium chloride (1 $\mathrm{mL}$ ) and warmed to r.t. The organic layer was then dried over magnesium sulphate and concentrated to afford a crude material 170 mg. The acid product was separated by a base wash to give 12 in a yield of $47 \mathrm{mg}$ (30.5\%). No further purification preformed.

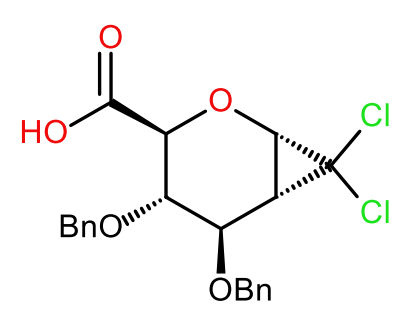

12) $R f=0.1$ (3:1 hexanes/ethyl acetate) 'H NMR: (500 $\mathrm{MHz}, \mathrm{CDCl}_{3}$ ) $\delta 11.87$ (bs, $\left.1 \mathrm{H}, \mathrm{COOH}\right), 7.41-7.20$ (complex m, 10H, Ph), $4.92(\mathrm{~d}, J=11.3 \mathrm{~Hz}, 1 \mathrm{H}$, $\left.\mathrm{PhCH}_{2}\right), 4.80\left(\mathrm{~d}, \mathrm{~J}=11.4 \mathrm{~Hz}, 1 \mathrm{H}, \mathrm{PhCH}_{2}\right), 4.65(\mathrm{t}, \mathrm{J}=$ $\left.11.3 \mathrm{~Hz}, 2 \mathrm{H}, \mathrm{PhCH}_{2}\right), 3.98(\mathrm{~d}, J=9.6 \mathrm{~Hz}, 1 \mathrm{H}, \mathrm{H}-1), 3.84$ $(\mathrm{m}, 1 \mathrm{H}, \mathrm{H}-3), 3.76(\mathrm{~m}, 2 \mathrm{H}, \mathrm{H}-4,5), 3.60(\mathrm{~d}, J=8.6 \mathrm{~Hz} 1 \mathrm{H}, \mathrm{H}-6 \mathrm{a}), 3.34$ (d, J = 8.6 $\mathrm{Hz} 1 \mathrm{H}, \mathrm{H}-6 \mathrm{~b}) 1.78(\mathrm{dd}, J=8.6,4.4 \mathrm{~Hz}, 1 \mathrm{H}, \mathrm{H}-2)$; further anaylsis is required. 


\section{1,5-Anhydro-3,4-di-O-benzyl-6-O-(triphenylcarbinyl)-2-deoxy-1,2-C- (dibromomethylene)-D-glycero-D-gulo-hexitol (13) and 1,5-anhydro-3,4- di-O-benzyl-6-O-(triphenylcarbinyl)-2-deoxy-1,2-C-(dibromomethylene)- D-glycero-D-talo-hexitol (14)}

A solution of 4 (508 mg, $0.87 \mathrm{mmol}$ ) and benzyltriethylammonium chloride (23 mg, $0.101 \mathrm{mmol}$ ) in bromoform $(1.5 \mathrm{~mL}$ ) was treated with a drop-wise solution of $33 \%$ aqueous sodium hydroxide $(3 \mathrm{~mL})$ and potassium fluoride $(2.0 \mathrm{~g}, 34.42 \mathrm{mmol})$ in water $(2.0 \mathrm{~mL})$. The biphasic mixture was stirred for five days at r.t. The mixture was diluted with water $(6 \mathrm{~mL})$, extracted with diethyl ether $(3 \times 15 \mathrm{~mL})$. The combined organic layer was washed with brine $(10 \mathrm{~mL})$, dried over magnesium sulphate and concentrated. The crude product was purified by column chromatography (hexanes/ethyl acetate 9:1) to give the major stereoisomer 13 in a yeild of $300 \mathrm{mg}$ (49.8\%) as an oil, in addition to the minor stereoisomer 14 in a yield of $83 \mathrm{mg}$ (12.8\%) as a yellow oil with a combined yield of $63 \%$.

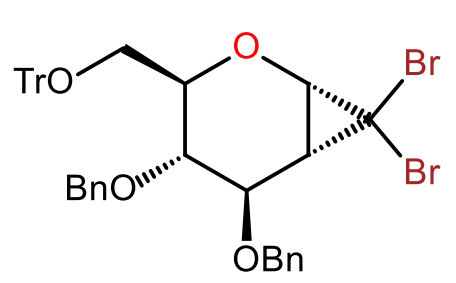

13) $R f=0.35$ (9:1 hexane/ethyl acetate) 'H NMR: (500 MHz, $\mathrm{CDCl}_{3}$ ) $\delta$ 7.43-7.21 (complex $\mathrm{m}, 23 \mathrm{H}$, $\mathrm{Ph}$ ), 7.02 (dd, 2H, Ph), $4.83(t, J=11.6 \mathrm{~Hz}, 2 \mathrm{H}$, $\left.\mathrm{PhCH}_{2}\right), 4.73\left(\mathrm{~d}, J=11.8 \mathrm{~Hz}, 1 \mathrm{H}, \mathrm{PhCH}_{2}\right), 4.25(\mathrm{~d}, J$ $\left.=10.7 \mathrm{~Hz}, 1 \mathrm{H}, \mathrm{PhCH}_{2}\right), 4.14(\mathrm{~d}, J=7.8 \mathrm{~Hz}, 1 \mathrm{H}, \mathrm{H}-1)$, 3.90- $3.94(\mathrm{~m}, 2 \mathrm{H}, \mathrm{H}-3, \mathrm{H}-4), 3.72$ (dd, J = 8.8, 4.9 Hz, H-5) 3.52 (d, J = 1.5 Hz, $1 \mathrm{H}, \mathrm{H}-6 \mathrm{a}$ ), 3.2 (d, J = 3.3 Hz, 1H, H-6b), 2.01 (dd, J = 7.8, $4.9 \mathrm{~Hz}, 1 \mathrm{H}, \mathrm{H}-2),{ }^{13} \mathrm{C}$ NMR: $\left(\mathrm{CDCl}_{3}\right) \& 143.8$ (C, Ph), 138.1 (C, Ph), 137.9 (C, Ph), 128.8 (CH, Ph), $128.6(\mathrm{CH}, \mathrm{Ph}), 128.3(\mathrm{CH}, \mathrm{Ph}), 128.1(\mathrm{CH}, \mathrm{Ph}), 128.09(\mathrm{CH}, \mathrm{Ph}), 128.08(\mathrm{CH}$, $\mathrm{Ph}), 128.06(\mathrm{CH}, \mathrm{Ph}), 127.8(\mathrm{CH}, \mathrm{Ph}), 127.3(\mathrm{CH}, \mathrm{Ph}), 86.9\left(\mathrm{C}, \mathrm{CPh}_{3}\right), 80.8$ $(\mathrm{CH}, \mathrm{C}-5), 80.1(\mathrm{CH}, \mathrm{C}-4), 75.7(\mathrm{CH}, \mathrm{C}-3), 75.0\left(\mathrm{CH}_{2}, \mathrm{PhCH}_{2}\right), 72.1\left(\mathrm{CH}_{2}\right.$, $\left.\mathrm{PhCH}_{2}\right), 63.7\left(\mathrm{CH}_{2}, \mathrm{C}-6\right), 59.7(\mathrm{CH}, \mathrm{C}-1), 35.7(\mathrm{C}, \mathrm{C}-2), 34.3\left(\mathrm{CBr}_{2}, \mathrm{C}-7\right), \mathrm{IR}$ (Film from $\mathrm{CHCl}_{3}$ ): U $\max 3434,3081,3012,2918,1710,1449,1364,1084,745$, 697, $632 \mathrm{~cm}^{-1} ; \mathrm{C}_{40} \mathrm{H}_{23} \mathrm{BrO}_{4} \mathrm{Na}^{+}[\mathrm{M}+\mathrm{Na}]^{+}$calculated 738.0980, found 738.1185. 


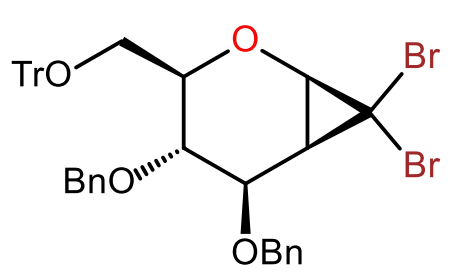

14) $R f=0.28$ (9:1 hexane/ethyl acetate) 'H NMR: (500 MHz, $\mathrm{CDCl}_{3}$ ) $\delta$ 7.53-7.31 (complex $\mathrm{m}, 23 \mathrm{H}$, Ph), 6.91 (dd, J= 7.6, 1.8 Hz, 2H, Ph), 4.92 (d, J = 2 $\left.\mathrm{Hz}, 1 \mathrm{H}, \mathrm{PhCH}_{2}\right), 4.75\left(\mathrm{~d}, J=1.9 \mathrm{~Hz}, 1 \mathrm{H}, \mathrm{PhCH}_{2}\right)$, $4.72\left(d, J=0.7 \mathrm{~Hz}, 1 \mathrm{H}, \mathrm{PhCH}_{2}\right), 4.37$ (d, J = $10.8 \mathrm{~Hz}$, $\left.1 \mathrm{H}, \mathrm{PhCH}_{2}\right), 4.22(\mathrm{dd}, J=7.55,10.25 \mathrm{~Hz}, 1 \mathrm{H}, \mathrm{H}-1), 4.11-4.15(\mathrm{~m}, 1 \mathrm{H}, \mathrm{H}-3), 3.57$ $(d d, J=10.3,1.7 \mathrm{~Hz}, \mathrm{H}-4) 3.42-3.46(\mathrm{~m}, 1 \mathrm{H}, \mathrm{H}-5), 3.31$ (dd, $J=10.3,1.7 \mathrm{~Hz}$, $1 \mathrm{H}, \mathrm{H}-6 \mathrm{a}) 3.20$ (dd, J = 10.3, 1.7 Hz, 1H, H-6b), $2.15(t, J=8.1 \mathrm{~Hz}, 1 \mathrm{H}, \mathrm{H}-2),{ }^{13} \mathrm{C}$ NMR: $\left(\mathrm{CDCl}_{3}\right) \delta 144.1$ (C, Ph), 138.8 (C, Ph), 138.1 (C, Ph), $128.9(\mathrm{CH}, \mathrm{Ph})$, $128.8(\mathrm{CH}, \mathrm{Ph}), 128.7(\mathrm{CH}, \mathrm{Ph}), 128.1(\mathrm{CH}, \mathrm{Ph}), 128.1(\mathrm{CH}, \mathrm{Ph}), 128.1(\mathrm{CH}$, $\mathrm{Ph}), 128.1(\mathrm{CH}, \mathrm{Ph}), 128.1(\mathrm{CH}, \mathrm{Ph}), 127.9(\mathrm{CH}, \mathrm{Ph}), 87.4\left(\mathrm{C}, \mathrm{CPh}_{3}\right), 81.1(\mathrm{CH}$, $\mathrm{C}-5), 80.5(\mathrm{CH}, \mathrm{C}-4), 75.5(\mathrm{CH}, \mathrm{C}-3), 75.1\left(\mathrm{CH}_{2}, \mathrm{PhCH}_{2}\right), 72.1\left(\mathrm{CH}_{2}, \mathrm{PhCH}_{2}\right)$, $63.9\left(\mathrm{CH}_{2}, \mathrm{C}-6\right), 60.7(\mathrm{CH}, \mathrm{C}-1), 37.5(\mathrm{C}, \mathrm{C}-2), 36.3\left(\mathrm{CBr}_{2}, \mathrm{C}-7\right)$, IR (Film from $\mathrm{CH}_{2} \mathrm{Cl}_{2}$ ): U $\max 3434,3082,3032,2918,1632,1448,1088,1020,913,737,697$ $\mathrm{cm}^{-1} ; \mathrm{C}_{40} \mathrm{H}_{23} \mathrm{BrO}_{4} \mathrm{Na}^{+}[\mathrm{M}+\mathrm{Na}]^{+}$calculated 738.0980 , found 738.1000

\section{1,5-Anhydro-3,4-di-O-benzyl-2-deoxy-1,2-C-(dichloromethylene)-D- glycero-D-gulo-hexitol (15)}

A solution of 13 (50 mg, $0.08 \mathrm{mmol})$ in diethyl ether $(0.3 \mathrm{~mL})$ was treated with formic acid $(0.4 \mathrm{~mL})$ and stirred at r.t. for $1 \mathrm{~h}$. The mixture was diluted with diethyl ether $(4 \mathrm{~mL})$ and washed with saturated sodium bicarbonate solution $(4 \times 10 \mathrm{~mL})$. The organic layer was dried over magnesium sulphate and concentrated. The crude product was purified by column chromatography (hexanes/ ethyl acetate gradient 14:1 to 5:1) to give 15 in a yield of $12 \mathrm{mg}(34 \%)$ as an oil.

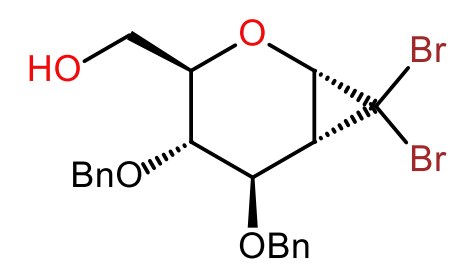

15) $R f=0.27$ (3: 1 hexanes/ ethyl acetate) 'H NMR: $\left(500 \mathrm{MHz}, \mathrm{CDCl}_{3}\right) \delta 7.43-4.25(\mathrm{~m}, 10 \mathrm{H}, \mathrm{Ph}), 4.94$ (d, $\left.J=11.4 \mathrm{~Hz}, 1 \mathrm{H}, \mathrm{Ph}-\mathrm{CH}_{2}\right), 4.80(\mathrm{~d}, J=11.7 \mathrm{~Hz}, 1 \mathrm{H}, \mathrm{Ph}-$ $\left.\mathrm{CH}_{2}\right), 4.71\left(\mathrm{~d}, J=11.4 \mathrm{~Hz}, 1 \mathrm{H}, \mathrm{Ph}-\mathrm{CH}_{2}\right), 4.60(\mathrm{~d}, J=$ $\left.11.3 \mathrm{~Hz}, 1 \mathrm{H}, \mathrm{Ph}-\mathrm{CH}_{2}\right), 3.90(\mathrm{~d}, J=8.4 \mathrm{~Hz}, 1 \mathrm{H}, \mathrm{H}-1)$, $3.89(\mathrm{~m}, 1 \mathrm{H}, \mathrm{H}-4), 3.71(\mathrm{dd}, J=9.0,4.1 \mathrm{~Hz}, 1 \mathrm{H}, \mathrm{H}-3), 3.60(\mathrm{~d}, J=3.9 \mathrm{~Hz}, 2 \mathrm{H}, \mathrm{H}-$ 
6a, H-6b), 3.64-3.60 (m, 1H, H-5), 1.99 (dd, J = 8.4, 4.5 Hz, 1H, H-2); ${ }^{13} \mathrm{C}$ NMR: $\left(\mathrm{CDCl}_{3}\right) \delta(\mathrm{C}, \mathrm{COH}),(\mathrm{C}, \mathrm{Ph}),(\mathrm{C}, \mathrm{Ph}),(\mathrm{CH}, \mathrm{Ph}),(\mathrm{CH}, \mathrm{Ph}),(\mathrm{CH}, \mathrm{Ph}),(\mathrm{CH}, \mathrm{Ph})$, $(\mathrm{CH}, \mathrm{Ph}),(\mathrm{CH}, \mathrm{Ph}),(\mathrm{CH}, \mathrm{C}-3),(\mathrm{CH}, \mathrm{C}-5),(\mathrm{CH}, \mathrm{C}-4),\left(\mathrm{CH}_{2}, \mathrm{PhCH}_{2}\right),\left(\mathrm{CH}_{2}\right.$, $\left.\mathrm{PhCH}_{2}\right),\left(\mathrm{CH}_{2}, \mathrm{C}-6\right),(\mathrm{CH}, \mathrm{C}-1),(\mathrm{C}, \mathrm{C}-7),(\mathrm{C}, \mathrm{C}-2)$;

\section{1,5-Anhydro-3,4-di-O-benzyl-2-deoxy-1,2-C-(dichloromethylene)-D- glycero-D-talo-hexitol (16)}

A solution of 14 (50 mg, $0.08 \mathrm{mmol})$ in diethyl ether $(0.3 \mathrm{~mL})$ was treated with formic acid $(0.4 \mathrm{~mL})$ and stirred at r.t. for one $\mathrm{h}$. The mixture was diluted with diethyl ether $(4 \mathrm{~mL})$ and washed with saturated sodium bicarbonate solution ( $4 \times 10 \mathrm{~mL})$. The organic layer was dried over magnesium sulphate concentrated. The crude product was purified by flash chromatography (hexanes/ethyl acetate gradient 14:1 to 5:1) to give 19 in a yeild of $6 \mathrm{mg}(17 \%)$ as an oil.

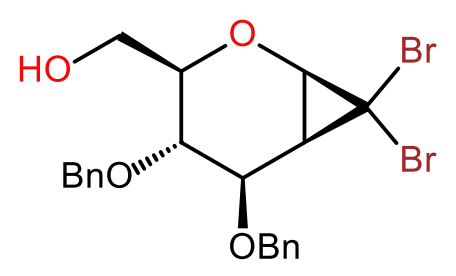

16) $R f=0.15$ (3:1 hexanes/ethyl acetate) 'H NMR: (500 MHz, $\left.\mathrm{CDCl}_{3}\right) \delta 7.43-4.25(\mathrm{~m}, 10 \mathrm{H}, \mathrm{Ph}), 4.94$ (d, $\left.J=11.4 \mathrm{~Hz}, 1 \mathrm{H}, \mathrm{Ph}-\mathrm{CH}_{2}\right), 4.83(\mathrm{~d}, J=11.7 \mathrm{~Hz}, 1 \mathrm{H}$,

$\left.\mathrm{Ph}-\mathrm{CH}_{2}\right), 4.71\left(\mathrm{~d}, \mathrm{~J}=11.4 \mathrm{~Hz}, 1 \mathrm{H}, \mathrm{Ph}-\mathrm{CH}_{2}\right), 4.61$ (d, J $\left.=11.3 \mathrm{~Hz}, 1 \mathrm{H}, \mathrm{Ph}-\mathrm{CH}_{2}\right), 4.00(\mathrm{~d}, J=8.4 \mathrm{~Hz}, 1 \mathrm{H}, \mathrm{H}-1)$,

$3.90(\mathrm{~m}, 1 \mathrm{H}, \mathrm{H}-4), 3.77(\mathrm{dd}, J=9.0,4.1 \mathrm{~Hz}, 1 \mathrm{H}, \mathrm{H}-3), 3.61(\mathrm{~d}, J=3.9 \mathrm{~Hz}, 2 \mathrm{H}, \mathrm{H}-$ 6a, H-6b), 3.69-3.65 (m, 1H, H-5), $2.09(t, J=8.4 \mathrm{~Hz}, 1 \mathrm{H}, \mathrm{H}-2) ;{ }^{13} \mathrm{C}$ NMR: $\left(\mathrm{CDCl}_{3}\right) \delta(\mathrm{C}, \mathrm{COH}),(\mathrm{C}, \mathrm{Ph}),(\mathrm{C}, \mathrm{Ph}),(\mathrm{CH}, \mathrm{Ph}),(\mathrm{CH}, \mathrm{Ph}),(\mathrm{CH}, \mathrm{Ph}),(\mathrm{CH}, \mathrm{Ph})$, $(\mathrm{CH}, \mathrm{Ph}),(\mathrm{CH}, \mathrm{Ph}),(\mathrm{CH}, \mathrm{C}-3),(\mathrm{CH}, \mathrm{C}-5),(\mathrm{CH}, \mathrm{C}-4),\left(\mathrm{CH}_{2}, \mathrm{PhCH}_{2}\right),\left(\mathrm{CH}_{2}\right.$, $\left.\mathrm{PhCH}_{2}\right),\left(\mathrm{CH}_{2}, \mathrm{C}-6\right),(\mathrm{CH}, \mathrm{C}-1),(\mathrm{C}, \mathrm{C}-7),(\mathrm{C}, \mathrm{C}-2)$ 


\section{1,5-Anhydro-3,4-di-O-benzyl-6-O-(triphenylcarbinyl)-2-deoxy-1,2-C- (methylene)-D-glycero-D-gulo-hexitol (17)}

To a solution of zinc $(0.314 \mathrm{~g}, 4.8 \mathrm{mmol})$, copper iodide $(0.091 \mathrm{~g}, 0.48$ $\mathrm{mmol}$ ) and methyl iodide $(6.25 \mathrm{~mL})$ in ether $(3 \mathrm{~mL})$ under nitrogen was treated with drop-wise with acetyl chloride $(0.16 \mathrm{~mL})$. The solution was heated in an oil bath for five min at $45^{\circ} \mathrm{C}$. A solution of 4 (300 mg, 0.53 $\mathrm{mmol}$ ) in ether ( $5 \mathrm{~mL}$ ) was added drop-wise to the heated mixture over 30 min, additional methyl iodide $(6.25 \mathrm{~mL})$ was added then the combined mixture was refluxed under nitrogen for $1 \mathrm{~h}$. The reaction mixture was cooled in an ice bath then quenched drop-wise with saturated ammonium chloride then filtered. The filtrate was washed with hexanes (3 x $5 \mathrm{~mL}$ ). The combined organic fractions were washed with $10 \%$ sodium hydroxide $(3 \times 5 \mathrm{~mL})$, combined organic fractions were dried over magnesium sulphate and concentrated. The crude product was purified by column chromatography (hexanes/ethyl acetate 5:1) to give 17 with a yield of $282 \mathrm{mg}(89 \%)$ as a whit solid. The spectral data matched to what had previously been reported (Nagarajan et al. 1997).

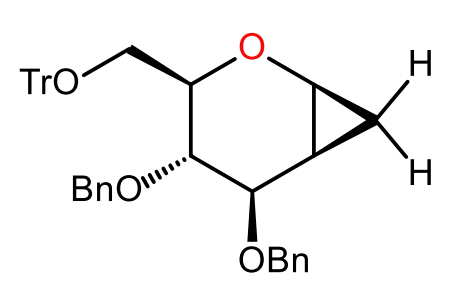

17) $R f=0.25$ (5:1 hexane/ethyl acetate) $1 \mathrm{H} \mathrm{NMR}$ (500 MHz, $\mathrm{CDCl}_{3}$ ): $\delta 0.82$ (app. dt, $J=9.8,5.8 \mathrm{~Hz}$,

$1 \mathrm{H}, \mathrm{H}-8), 0.91(\mathrm{dt}, J=6.8,2.4 \mathrm{~Hz}, 1 \mathrm{H}, \mathrm{H}-9), 1.33$ (app. dq, J = 9.7, $7.0 \mathrm{~Hz}, 1 \mathrm{H}, \mathrm{H}-2$ ), 3.12 (dd, J = $10.1,4.3 \mathrm{~Hz}, 1 \mathrm{H}, \mathrm{H}-3), 3.33-3.43(\mathrm{~m}, 3 \mathrm{H}, \mathrm{H}-4, \mathrm{H}-6, \mathrm{H}-$ 7), 3.81 (ddd, J= 7.0, 5.8, $2.8 \mathrm{~Hz} 1 \mathrm{H}, \mathrm{H}-1$ ) , $4.06(t, J=6.9 \mathrm{~Hz}, 1 \mathrm{H}, \mathrm{H}-5), 4.38$ (d, $\left.J=10.8 \mathrm{~Hz}, 1 \mathrm{H}, \mathrm{CH}_{2} \mathrm{Ph}\right), 4.61\left(\mathrm{~d}, J=11.7 \mathrm{~Hz}, 1 \mathrm{H}, \mathrm{CH}_{2} \mathrm{Ph}\right), 4.70(\mathrm{~d}, J=10.7 \mathrm{~Hz}$, $\left.1 \mathrm{H}, \mathrm{CH}_{2} \mathrm{Ph}\right), 4.83\left(\mathrm{~d}, J=11.7 \mathrm{~Hz}, 1 \mathrm{H}, \mathrm{CH}_{2} \mathrm{Ph}\right), 6.93$ (dd, J = 7.5, $1.8 \mathrm{~Hz}, 2 \mathrm{H}, \mathrm{Ph}$ ),

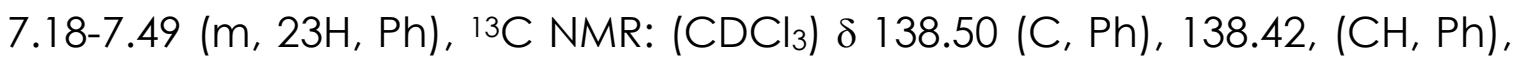
$138.43(\mathrm{CH}, \mathrm{Ph}) 128.43(\mathrm{CH}, \mathrm{Ph}), 128.03(\mathrm{CH}, \mathrm{Ph}), 127.87(\mathrm{CH}, \mathrm{Ph}), 127.74$ $(\mathrm{CH}, \mathrm{Ph}), 127.57(\mathrm{CH}, \mathrm{Ph}), 78.74(\mathrm{CH}, \mathrm{C}-3), 78.55(\mathrm{CH}, \mathrm{C}-5), 77.92(\mathrm{CH}, \mathrm{C}-4)$, $74.21\left(\mathrm{CH}_{2}, \mathrm{PhCH}_{2}\right), 70.0\left(\mathrm{CH}_{2}, \mathrm{PhCH}_{2}\right), 62.52\left(\mathrm{CH}_{2}, \mathrm{C}-6\right), 55.10(\mathrm{CH}, \mathrm{C}-1)$, 15.69 (C, C-7), 11.98 (C, C-2). 


\section{1,5-Anhydro-3,4-di-O-benzyl-2-deoxy-1,2-C-(methylene)-D-glycero-D- gulo-hexitol (18)}

A solution of 21 (50 mg, $0.08 \mathrm{mmol}$ ) in diethyl ether $(0.3 \mathrm{~mL}$ ) was treated with formic acid $(0.4 \mathrm{~mL})$ and stirred at r.t. for $1 \mathrm{~h}$. The mixture was diluted with diethyl ether $(4 \mathrm{~mL})$ and washed with saturated sodium bicarbonate solution $(4 \times 10 \mathrm{~mL})$. The organic layer was dried over magnesium sulphate and concentrated. The crude product was purified by column chromatography (hexanes/ethyl acetate gradient 14:1 to 5:1) to give 22 with a yield of $18 \mathrm{mg}(65 \%)$ as an oil. The spectral data matched to what had previously been reported (Nagarajan et al. 1997).

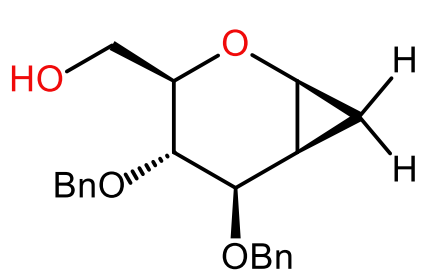

18) $R f=0.12$ (3:1 hexane/ethyl acetate). IHNMR (500 MHz, $\left.\mathrm{CDCl}_{3}\right): \delta$ 7.35-7.29 (m, 10H, Ph), 4.89 (

$\left.2 \mathrm{H}, \mathrm{CH}_{2} \mathrm{Ph}\right), 4.74$ (t, $\left.2 \mathrm{H}, \mathrm{CH}_{2} \mathrm{Ph}\right), 3.87(\mathrm{~m}, 1 \mathrm{H}, \mathrm{C}-1)$, $3.40(\mathrm{~m}, 3 \mathrm{H}, \mathrm{C}-3, \mathrm{C}-4, \mathrm{C}-5), 2.11\left(\mathrm{dd}, 2 \mathrm{H}, \mathrm{C}-6, \mathrm{C}-6^{\prime}\right)$, $1.08-0.93(\mathrm{~m}, 1 \mathrm{H}, \mathrm{C}-2), 0.81-0.69(\mathrm{~m}, 2 \mathrm{H}, \mathrm{C}-7, \mathrm{CPH} 3)$; ${ }^{13} \mathrm{C}$ NMR: $\left(\mathrm{CDCl}_{3}\right) \delta 138.49(\mathrm{C}, \mathrm{COH}), 138.35,(\mathrm{CH}, \mathrm{Ph}), 128.51(\mathrm{CH}, \mathrm{Ph})$, $128.0(\mathrm{CH}, \mathrm{Ph}), 127.79(\mathrm{CH}, \mathrm{Ph}), 126.98(\mathrm{CH}, \mathrm{Ph}), 79.61(\mathrm{CH}, \mathrm{C}-3), 76.91(\mathrm{CH}$, $\mathrm{C}-5), 76.53(\mathrm{CH}, \mathrm{C}-4), 73.61\left(\mathrm{CH}_{2}, \mathrm{PhCH}_{2}\right), 71.25\left(\mathrm{CH}_{2}, \mathrm{PhCH}_{2}\right), 62.58\left(\mathrm{CH}_{2}\right.$, C-6), $49.98(\mathrm{CH}, \mathrm{C}-1), 14.43(\mathrm{C}, \mathrm{C}-7), 10.29$ (C, C-2).

\section{p-Azidotoluene (19)}

p-Tolvidine ( $1 \mathrm{~g}, 9.2 \mathrm{mmol})$ in water $(12 \mathrm{~mL})$ and hydrochloric acid $(37 \%, 12$ $\mathrm{mL})$ were reacted with sodium nitrite $(0.756 \mathrm{~g}, 10.8 \mathrm{mmol})$ for $2 \mathrm{~h}$ of $0^{\circ} \mathrm{C}$. The diazonium salt was then treated with sat. sodium acetate $(15.1 \mathrm{~g}, 368$ mmol) and sodium azide $(1.2 \mathrm{~g}, 18.4 \mathrm{mmol})$. The resulted mixture was extracted with portions of 2:1 ethyl acetate/hexane $(20 \mathrm{~mL})$ and the combined organic extracts were treated with brine $(20 \mathrm{~mL})$ and dried with magnesium sulphate. Resulting in p-azidotolvene as a yellow/orange oil with a distinct smell 23 (95\% yield). The spectral data matched to what had previously been reported (Smith et al. 2011) 
19) ${ }^{1} \mathrm{H}$ NMR $\left(300 \mathrm{MHz} ; \mathrm{CDCl}_{3}\right): \delta=6.91-7.18(\mathrm{~m}, 4 \mathrm{H}, \mathrm{CH}), 2.34$ (s, $\left.3 \mathrm{H}, \mathrm{CH}_{3}\right) \mathrm{ppm} .{ }^{13} \mathrm{C} \mathrm{NMR}(500 \mathrm{MHz} ; \mathrm{CDCl} 3): \delta=20.8$ (1C, N3-C-CH), $118.8\left(2 \mathrm{C}, \mathrm{N}_{3}-\mathrm{C}-\mathrm{CH}\right), 130.3\left(2 \mathrm{C}, \mathrm{CH}_{3}-\mathrm{C}-\mathrm{CH}\right), 134.6\left(1 \mathrm{C}, \mathrm{CH}_{3}-\mathrm{C}\right)$,

\section{p-Azidobenzyl bromide (20)}

A solution of 19 (0.665 g, $5 \mathrm{mmol}), \mathrm{N}$-bromosuccinimide (0.98 g, $5.5 \mathrm{mmol})$ and azobisisobutyronitrile $(0.08 \mathrm{~g})$ was heated in the dark under nitrogen in refluxing dry benzene for $5 \mathrm{~h}$. The mixture was poured into water and diethyl ether. The organic layer was dried over magnesium sulphate and concentrated. The residue was dissolved in a small volume of light petroleum and purified by column chromatography (hexanes) resulting in p-azidobenzyl bromide with a yield of $65 \%$ as an orange liquid. The spectral data matched to what had been previously reported (Gubbens et al. 2009). Please note; p-azidobenzyl bromide is a strong irritant to the eyes that causes a high degree of discomfort and should kept in a closed system and prior to cleaning be quenched with water within the fumehood.

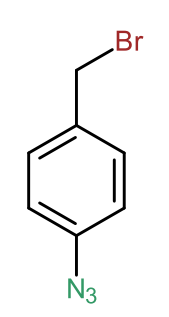

20) $1 \mathrm{H}$ NMR (500 MHz, CDCl $)$ ): $\delta 7.38$ (d, J = $8.5 \mathrm{~Hz}, 2 \mathrm{H}, \mathrm{Ph}$ ), 7.00 (d, J $8.5 \mathrm{~Hz}, 2 \mathrm{H}, \mathrm{Ph}), 4.48\left(\mathrm{~s}, 2 \mathrm{H}, \mathrm{CH}_{2}\right) ;{ }^{13} \mathrm{C} \mathrm{NMR}\left(75.5 \mathrm{MHz}, \mathrm{CDCl}_{3}\right) \delta$ $45.6(1 \mathrm{C}, \mathrm{C}-1), 119.1,130.1,134.1,140.1$.

\section{1,5-Anhydro-3,4-di-O-(p-azidophenyl)methoxy-2-deoxy-6-O-trityl-D- arabino-hex-1-enitol (21)}

Trityl-D-glucal (400 mg, $0.810 \mathrm{mmol}$ ) was dissolved in dimethylformamide $\left(10 \mathrm{~mL}\right.$ ) and cooled in an ice bath to $-10^{\circ} \mathrm{C}$. sodium hydride (48 mg, 2.20 mmol) was then added portion-wise over 1 min and the solution was 
stirred for $10 \mathrm{~min}$, which was then followed by the addition of $p$ azidobenzyl bromide (20) (400 mg, $1.89 \mathrm{mmol}$ ). The solution was warmed to r.t. and stirred for $16 \mathrm{~h}$, followed by quenching with water $(20 \mathrm{~mL})$ and extraction with chloroform $(3 \times 10 \mathrm{~mL})$. The organic layers were combined and reduced to $10 \mathrm{~mL}$ and washed with aqueous sat. copper sulphate (4 $x 10 \mathrm{~mL}$ ). The organic layer was then dried with magnesium sulphate and concentrated, to provide a crude mixture that was purified by column chromatography (hexanes/ethyl acetate 9:1) resulting in $\mathbf{2 1}$ in a yield of $250 \mathrm{mg}(47.6 \%)$ as an oil.

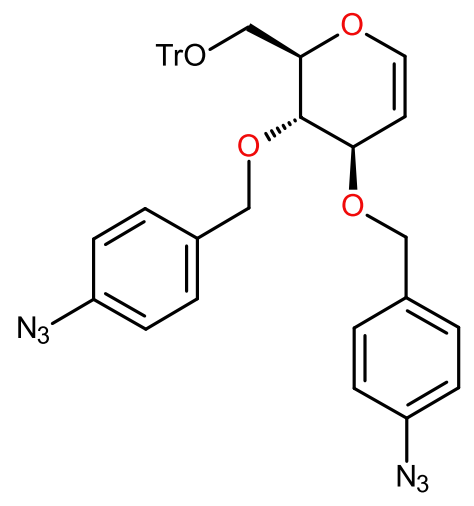

21) $R f=0.7$ (5:1 hexanes/ethyl acetate) ${ }^{1} H$ NMR: $\left(500 \mathrm{MHz}, \mathrm{CDCl}_{3}\right.$ ) $\delta$ 7.42- 7.30 (complex $\mathrm{m}, 7 \mathrm{H}$, Ph), 7.30- 7.05 (complex $\mathrm{m}, 12 \mathrm{H}, \mathrm{Ph}$ ), 6.88 (d, $J=$ $\left.8.4 \mathrm{~Hz}, 2 \mathrm{H}, \mathrm{PhN}_{3}\right), 6.79\left(\mathrm{~d}, J=8.4 \mathrm{~Hz}, 2 \mathrm{H}, \mathrm{PhN}_{3}\right)$, $6.43(d, J=6.3 \mathrm{~Hz}, 1 \mathrm{H}, \mathrm{H}-2), 4.79(\mathrm{dd}, J=6.3,3.1$ $\mathrm{Hz}, 1 \mathrm{H}, \mathrm{H}-1), 4.69\left(\mathrm{~d}, J=11.3 \mathrm{~Hz}, 1 \mathrm{H}, \mathrm{PhCH}_{2}\right), 4.65$ (d, J = $\left.11.4 \mathrm{~Hz}, 1 \mathrm{H}, \mathrm{PhCH}_{2}\right), 4.45$ (d, J = $11.3 \mathrm{~Hz}$, $\left.1 \mathrm{H}, \mathrm{PhCH}_{2}\right), 4.35$ (d, J = $\left.11.3 \mathrm{~Hz}, 1 \mathrm{H}, \mathrm{PhCH}_{2}\right), 4.15-$ 4.00 (complex m, 2H, H-3,4), 3.90 (d, J = $6.3 \mathrm{~Hz}, 1 \mathrm{H}, \mathrm{H}-5$ ), 3.48 (dd, $J=10.2$, $2.4 \mathrm{~Hz}, 1 \mathrm{H}, \mathrm{H}-6 \mathrm{a}), 3.25$ (d, J = 10.1, $2.4 \mathrm{~Hz}, 1 \mathrm{H}, \mathrm{H}-6 \mathrm{~b}) ;{ }^{13} \mathrm{C}$ NMR $(75.5 \mathrm{MHz}$, $\left.\mathrm{CDCl}_{3}\right) \delta 144.9(\mathrm{CH}, \mathrm{C}-1), 143.8$ (C, Ph), 134.9 (C, Ph), 129.5 (C, Ph), 128.7 $(\mathrm{CH}, \mathrm{Ph}), 127.8(\mathrm{CH}, \mathrm{Ph}), 127.0(\mathrm{CH}, \mathrm{Ph}), 118.8\left(\mathrm{C}, \mathrm{CN}_{3}\right), 99.7(\mathrm{CH}, \mathrm{C}-2), 76.9$ (C, $\left.\mathrm{CPh}_{3}\right), 76.3(\mathrm{CH}, \mathrm{C}-5), 74.6(\mathrm{CH}, \mathrm{C}-4), 73.2\left(\mathrm{CH}_{2}, \mathrm{PhCH}_{2}\right), 70.8\left(\mathrm{CH}_{2}\right.$, $\left.\mathrm{PhCH}_{2}\right), 62.0\left(\mathrm{CH}_{2}, \mathrm{C}-6\right)$; IR (Film from $\left.\mathrm{CH}_{2} \mathrm{Cl}_{3}\right) \mathrm{U}_{\max }$

\section{1,5-Anhydro-4-O-(p-azidophenyl)-2-deoxy-6-O-trityl-D-arabino-hex-1- enitol (22)}

Trityl-D-glucal 3 (1.8 g, $3.7 \mathrm{mmol}$ ) was dissolved in dimethylformamide (20 $\mathrm{mL}$ ) and cooled in an ice/calcium chloride bath to $-10^{\circ} \mathrm{C}$. Sodium hydride (48 mg, $2.20 \mathrm{mmol}$ ) was then added portion-wise over $1 \mathrm{~min}$ and the solution was stirred for 10 min, which was then followed by the addition of p-azidobenzyl bromide (20) (400 mg, $1.89 \mathrm{mmol})$. The solution was warmed 
to $r . t$ and stirred for $16 \mathrm{~h}$, followed by quenching with water $(40 \mathrm{~mL})$ and extraction with chloroform $(3 \times 20 \mathrm{~mL})$ the organic layers were combined and reduced to $10 \mathrm{~mL}$ which was then washed by aqueous sat. copper sulphate $(6 \times 20 \mathrm{~mL})$. The organic layer was then dried with magnesium sulphate and concentrated, to provide a crude mixture that was purified by column chromatography (hexanes/ethyl acetate 9:1) resulting in 21 in a yield of $439 \mathrm{mg}(36.4 \%)$ as an oil.

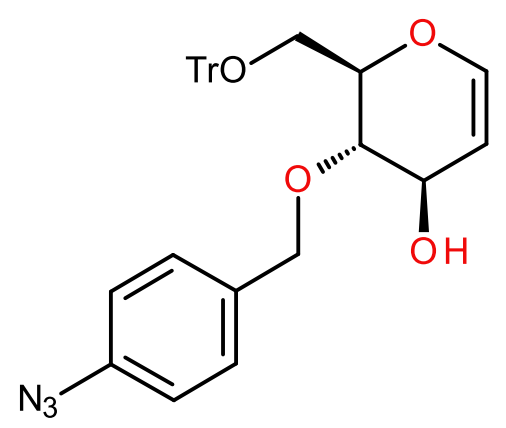

22) $R f=0.28\left(5: 1\right.$ hexanes/ ethyl acetate) ${ }^{1} \mathrm{H}$ NMR: $\left(500 \mathrm{MHz}, \mathrm{CDCl}_{3}\right) \delta 7.51-7.45(\mathrm{~m}, 7 \mathrm{H}, \mathrm{Ph})$, 7.33-7.23 (m, 8H, Ph), 7.04 (d, J = 8.3 Hz, 2H, $\left.\mathrm{PhN}_{3}\right), 6.90\left(\mathrm{~d}, J=8.5 \mathrm{~Hz}, 2 \mathrm{H}, \mathrm{PhN}_{3}\right), 6.51(\mathrm{~d}, J=$ $6.1 \mathrm{~Hz}, 1 \mathrm{H}, \mathrm{H}-2), 4.77$ (dd, J = 6.1, $2.4 \mathrm{~Hz}, 1 \mathrm{H}, \mathrm{H}-$ 1), $4.62\left(\mathrm{~d}, J=11.2 \mathrm{~Hz}, 1 \mathrm{H}, \mathrm{PhCH}_{2}\right), 4.45(\mathrm{~d}, J=$ $\left.11.2 \mathrm{~Hz}, 1 \mathrm{H}, \mathrm{PhCH}_{2}\right), 4.32(\mathrm{t}, J=6.1 \mathrm{~Hz}, 1 \mathrm{H}, \mathrm{H}-3)$,

$3.93(\mathrm{dd}, J=9.3,3.0 \mathrm{~Hz}, 1 \mathrm{H}, \mathrm{H}-4), 3.82$ (dd, J = 9.2, $6.7 \mathrm{~Hz}, 1 \mathrm{H}, \mathrm{H}-5), 3.65$ (dd, $J=10.3,2.2 \mathrm{~Hz}, 1 \mathrm{H}, \mathrm{H}-6 \mathrm{a}), 3.27(\mathrm{dd}, J=10.3,3.4 \mathrm{~Hz}, 1 \mathrm{H}, \mathrm{H}-6 \mathrm{~b}), 1.91$ (apparent $t, 1 \mathrm{H}, \mathrm{OH}$ );

\section{1,5-Anhydro-3,4-di-O-(p-azidophenyl)methoxyl-6-O-(triphenyl-c-arbinyl)-}

\section{2-deoxy-1,2-C-(dichloromethylene)-D-glycero-D-gulo-hexitol}

Following the methodology of Nagarajan et al. (1997) a solution of 21 (200 $\mathrm{mg}, 0.3 \mathrm{mmol}$ ) and benzyltriethylammonium chloride (10 $\mathrm{mg}, 0.04 \mathrm{mmol}$ ) in chloroform (5 mL) was treated drop-wise with $33 \%$ aqueous sodium hydroxide $(10 \mathrm{~mL})$ with rapid stirring. The biphasic mixture was stirred at r.t. for $10 \mathrm{~h}$. The Biphasic mixture was then diluted with water $(10 \mathrm{~mL})$ and extracted with dichloromethane $(3 \times 20 \mathrm{~mL})$. The organic fractions were combined and dried by magnesium sulphate and concentrated to provide a crude mixture. The crude product was purified by column chromatography (hexanes/ethyl acetate 14:1) giving the major cyclopropane $\mathbf{2 3}$ in a yield of $20 \mathrm{mg}(\mathbf{9 \% )}$ as a colourless oil. 


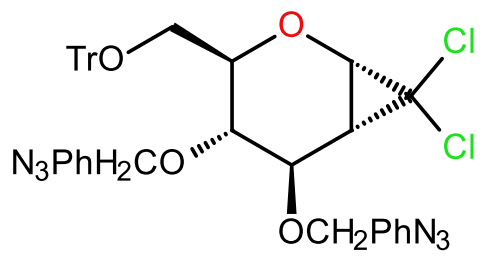

23) $R f=0.3$ (9:1 hexanes /ethyl acetate); ${ }^{1} \mathrm{H}$ NMR: $\left(500 \mathrm{MHz}, \mathrm{CDCl}_{3}\right) \delta 7.47(\mathrm{~d}, J=8.3 \mathrm{~Hz}, 2 \mathrm{H}$, $\left.\mathrm{PhN}_{3}\right), 7.22\left(\mathrm{~d}, J=8.3 \mathrm{~Hz}, 2 \mathrm{H}, \mathrm{PhN}_{3}, 7.05(\mathrm{~d}, J=\right.$ $\left.8.3 \mathrm{~Hz}, 2 \mathrm{H}, \mathrm{PhN}_{3}\right), 7.95\left(\mathrm{~d}, J=8.0 \mathrm{~Hz}, 2 \mathrm{H}, \mathrm{PhN}_{3}\right.$ ), $4.81\left(\mathrm{~d}, J=11.6 \mathrm{~Hz}, 1 \mathrm{H}, \mathrm{PhCH}_{2}\right), 4.78(\mathrm{~d}, J=10.7$ $\left.\mathrm{Hz}, 1 \mathrm{H}, \mathrm{PhCH}_{2}\right), 4.70\left(\mathrm{~d}, J=11.6 \mathrm{~Hz}, 1 \mathrm{H}, \mathrm{PhCH}_{2}\right), 4.30(\mathrm{~d}, J=10.7 \mathrm{~Hz}, 1 \mathrm{H}$, $\mathrm{PhCH}_{2}$ ), 4.10 (d, J = 8.0 Hz, 1H, H-1), 3.88-3.80 (complex m, 2H H-4,5), 3.75 (dd, J = 8.4, 4.2 Hz, 1H, H-3), 3.49 (dd, J = 10.2, 3.0 Hz, 1H, H-6a), 3.23 (dd, J $=10.2,3.0 \mathrm{~Hz}, 1 \mathrm{H}, \mathrm{H}-6 \mathrm{~b}), 1.90$ (dd, J = 8.0, $4.9 \mathrm{~Hz}, 1 \mathrm{H}, \mathrm{H}-2) ;{ }^{13} \mathrm{C} \mathrm{NMR:}\left(\mathrm{CDCl}_{3}\right)$ $\delta(\mathrm{C}, \mathrm{Ph}),(\mathrm{C}, \mathrm{Ph}),(\mathrm{CH}, \mathrm{Ph}),(\mathrm{CH}, \mathrm{Ph}),(\mathrm{CH}, \mathrm{Ph}),(\mathrm{CH}, \mathrm{Ph}),(\mathrm{CH}, \mathrm{Ph}),(\mathrm{CH}, \mathrm{C}-5)$, $(\mathrm{CH}, \mathrm{C}-3),\left(\mathrm{CH}_{2}, \mathrm{PhCH}_{2}\right),(\mathrm{CH}, \mathrm{C}-4),\left(\mathrm{CH}_{2}, \mathrm{PhCH}_{2}\right),\left(\mathrm{CH}_{2}, \mathrm{C}-6\right),(\mathrm{C}, \mathrm{C}-7)$, $(\mathrm{CH}, \mathrm{C}-1),(\mathrm{CH}, \mathrm{C}-2)$; IR (Film from $\left.\mathrm{CH}_{2} \mathrm{Cl}_{3}\right) \mathrm{U}_{\max } 3016,2970,2113,1444,1365$, $1092,1025,900,760,701 \mathrm{~cm}^{-1}$

\section{1,5-Anhydro-3,4-di-O-(p-azidophenyl)methoxy-2-deoxy-1,2-C- (dichloromethylene)-D-glycero-D-gulo-hexitol}

A solution of $23(20 \mathrm{mg}, 0.027 \mathrm{mmol})$ in diethyl ether $(0.3 \mathrm{~mL})$ was treated with formic acid $(0.4 \mathrm{~mL})$ and stirred at r.t. for one $\mathrm{h}$. The mixture was diluted with diethyl ether $(4 \mathrm{~mL})$ and washed with saturated sodium bicarbonate solution $(4 \times 10 \mathrm{~mL})$. The organic layer was dried over magnesium sulphate and concentrated. The crude product was purified by column chromatography (hexanes/ethyl acetate gradient 14:1 to 5:1) to give 24 in a yield of $6.5 \mathrm{mg}(48 \%)$ as an oil, and 25 (1 mg 7\%).

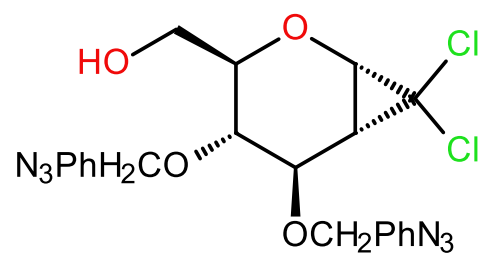

24) $R f=0.30(3: 1 \text { hexanes/ethyl acetate })^{1} \mathrm{H}$ NMR: $\left(500 \mathrm{MHz}, \mathrm{CDCl}_{3}\right) \delta 7.45$ (d, J = $8.3 \mathrm{~Hz}, 2 \mathrm{H}$, $\left.\mathrm{PhN}_{3}\right), 7.36\left(\mathrm{~d}, J=8.3 \mathrm{~Hz}, 2 \mathrm{H}, \mathrm{PhN}_{3}, 7.14(\mathrm{~d}, J=\right.$ $\left.8.3 \mathrm{~Hz}, 2 \mathrm{H}, \mathrm{PhN}_{3}\right), 7.10\left(\mathrm{~d}, J=8.0 \mathrm{~Hz}, 2 \mathrm{H}, \mathrm{PhN}_{3}\right)$, $4.91\left(\mathrm{~d}, J=11.3 \mathrm{~Hz}, 1 \mathrm{H}, \mathrm{PhCH}_{2}\right), 4.79(\mathrm{~d}, J=12$ $\left.\mathrm{Hz}, 1 \mathrm{H}, \mathrm{PhCH}_{2}\right), 4.68\left(t, J=11.1 \mathrm{~Hz}, 1 \mathrm{H}, \mathrm{PhCH}_{2}\right), 3.89(\mathrm{~d}, J=9.5 \mathrm{~Hz}, 1 \mathrm{H}, \mathrm{H}-1)$, 3.79 (dd, J = 9.3, 3.9 Hz, 1H, H-4), $3.75(\mathrm{~m}, 1 \mathrm{H}, \mathrm{H}-3), 3.71(\mathrm{~m}, 2 \mathrm{H}, \mathrm{H}-6 \mathrm{a}, \mathrm{b}), 3.62$ $(t, J=9.2, \mathrm{~Hz}, 1 \mathrm{H}, \mathrm{H}-5), 1.82(\mathrm{dd}, J=8.3,3.9 \mathrm{~Hz}, 1 \mathrm{H}, \mathrm{H}-2) ;{ }^{13} \mathrm{C} \mathrm{NMR:}\left(\mathrm{CDCl}_{3}\right) \delta$ 
135.8 (C, Ph), 135.8 (C, Ph), 135.1 (CH, Ph), $134.5(\mathrm{CH}, \mathrm{Ph}), 129.1(\mathrm{CH}, \mathrm{Ph})$, $129.1(\mathrm{CH}, \mathrm{Ph}), 118.8\left(\mathrm{CN}_{3}, \mathrm{Ph}\right), 118.7\left(\mathrm{CN}_{3}, \mathrm{Ph}\right), 79.5(\mathrm{CH}, \mathrm{C}-5), 76.1\left(\mathrm{CH}_{2}\right.$, $\left.\mathrm{PhCH}_{2}\right), 74.9(\mathrm{CH}, \mathrm{C}-4), 74.2\left(\mathrm{CH}_{2}, \mathrm{PhCH}_{2}\right), 71.4(\mathrm{CH}, \mathrm{C}-3), 62.6\left(\mathrm{CH}_{2}, \mathrm{C}-6\right)$, 60.8 (C, C-7), $58.8(\mathrm{CH}, \mathrm{C}-1), 33.7(\mathrm{CH}, \mathrm{C}-2)$; IR (Film from $\left.\mathrm{CH}_{2} \mathrm{Cl}_{3}\right)$ Umax 3415 , $2980,2358,2346,2340,1611,1512,1359,1095,841,670 \mathrm{~cm}^{-1}$.

\section{1,5-Anhydro-6-O-(triphenylcarbinyl)-2-deoxy-1,2-(dichloromethylene)-D- glycero-D-gulo-hexitol (25) 1,5-Anhydro-4-O-benzyl-2-deoxy-1,2-C- (dichloromethylene)-D-glycero-D-gulo-hexitol (27)}

Compound 5 (920 g, $1.45 \mathrm{mmol})$ was taken up in warm ethanol (30 mL) under nitrogen flow and 10\% $\mathrm{Pd} / \mathrm{C}(\sim 80 \mathrm{mg})$ and three drops of acetic acid were added to the mixture. The reaction vessel was purged with hydrogen gas and the mixture was vigorously stirred for $24 \mathrm{~h}$. The reaction mixture was filtered through celite and concentrated. The crude product was purified by column chromatography (hexanes/ethyl acetate gradient 9:1 to 1:1) resulting in four colourless oils 7 in a yield of $180 \mathrm{mg}(30 \%), 25 \mathrm{in}$ $30 \mathrm{mg}$ (5\%), 26 in $103 \mathrm{mg}$ (31\%) and 27 in $103 \mathrm{mg}$ (31\%).

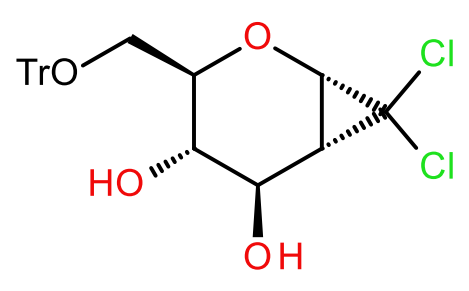

25) $R f=0.8\left(1: 1\right.$ hexanes/ethyl acetate) ${ }^{H} H$ NMR: (500 MHz, $\left.\mathrm{CDCl}_{3}\right) \delta 7.51-7.23(\mathrm{~m}, 15 \mathrm{H}, \mathrm{Ph}), 3.86$ (d, J $=8.6 \mathrm{~Hz}, 1 \mathrm{H}, \mathrm{H}-1), 3.80-3.65(\mathrm{~m}, 2 \mathrm{H}, \mathrm{H}-3,4)$, 3.62- $3.58(\mathrm{~m}, 1 \mathrm{H}, \mathrm{H}-5), 3.41(\mathrm{dd}, J=6.8,1.5 \mathrm{~Hz}$, $1 \mathrm{H}, \mathrm{H}-6 \mathrm{a}), 3.31$ (dd, J=1.4, 6.9 Hz, 1H, H-6b), 3.12 (bs, 2H, OH), 1.89 (dd, J = 8.6, 3.6 Hz, 1H, H-2), $\left.{ }^{13} \mathrm{C} \mathrm{NMR:} \mathrm{(CDCl} 3\right) 146.9$ (C) $\mathrm{Ph}), 144.4$ (C, Ph), 143.5 (C, Ph), $128.6(\mathrm{CH}, \mathrm{Ph}), 128.6(\mathrm{CH}, \mathrm{Ph}), 128.0(\mathrm{CH}$, $\mathrm{Ph}), 127.7(\mathrm{CH}, \mathrm{Ph}), 127.3(\mathrm{CH}, \mathrm{Ph}), 126.8(\mathrm{CH}, \mathrm{Ph}), 82.0\left(\mathrm{C}, \mathrm{C}-\mathrm{Ph}_{3}\right), 78.2(\mathrm{CH}$, $\mathrm{C}-5), 69.4(\mathrm{CH}, \mathrm{C}-4), 68.9(\mathrm{CH}, \mathrm{C}-3), 68.5\left(\mathrm{CCl}_{2}, \mathrm{C}-7\right), 62.5\left(\mathrm{CH}_{2}, \mathrm{C}-6\right), 58.9$ $(\mathrm{CH}, \mathrm{C}-1), 34.1(\mathrm{CH}, \mathrm{C}-2)$; IR (Film from $\left.\mathrm{CH}_{2} \mathrm{Cl}_{3}\right) \mathrm{U}_{\max } 3460,3058,3021,1591$, 1492, 1444, 1328, 1156, 1010,758,706, $638 \mathrm{~cm}^{-1} ; \mathrm{C}_{26} \mathrm{H}_{24} \mathrm{Cl}_{2} \mathrm{O}_{4} \mathrm{Na}^{+}[\mathrm{M}+\mathrm{Na}]^{+}$ calculated 470.1052 , found 470.1046 


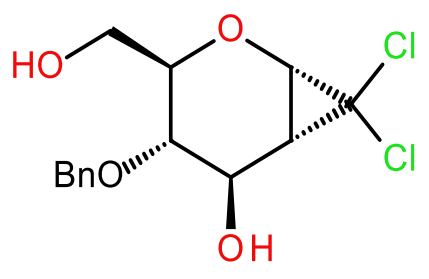

27) $R f=0.2$ (1:1 hexanes/ethyl acetate) $1 \mathrm{H}$ NMR: (500 MHz, $\mathrm{CDCl}_{3}$ ) $\delta$ 7.40- 7.30 (m, 5H, Ph), 4.79 (d, J $\left.=11.7 \mathrm{~Hz}, 1 \mathrm{H}, \mathrm{PhCH}_{2}\right), 4.76\left(\mathrm{~d}, \mathrm{~J}=, 1 \mathrm{H}, \mathrm{PhCH}_{2}\right), 3.89$ $(d, J=11.5 \mathrm{~Hz}, 1 \mathrm{H}, \mathrm{H}-1), 3.78(\mathrm{~s}, 1 \mathrm{H}, \mathrm{H}-3), 3.69(\mathrm{~m}$, $2 \mathrm{H}, \mathrm{H}-4,5), 3.60$ (dd, J = 8.6, 3.8 Hz, 2H, H-6a, 6b)

2.62 (bs, $1 \mathrm{H}, \mathrm{OH}$ ), 2.0 (bs, $1 \mathrm{H}, \mathrm{OH}$ ), 1.79 ( dd, J = 8.5, $3.6 \mathrm{~Hz}, 1 \mathrm{H}, \mathrm{H}-2$ ). ${ }^{13} \mathrm{C}$ NMR: (CDCl $) 136.9$ (C, Ph), $128.7(\mathrm{CH}, \mathrm{Ph}), 128.4(\mathrm{CH}, \mathrm{Ph}), 128.3(\mathrm{CH}, \mathrm{Ph})$, $79.1(\mathrm{CH}, \mathrm{C}-5), 76.1\left(\mathrm{CH}_{2}, \mathrm{PhCH}_{2}\right), 72.1(\mathrm{CH}, \mathrm{C}-4), 68.2(\mathrm{CH}, \mathrm{C}-3), 63.1\left(\mathrm{CH}_{2}\right.$, C-6), 61.1 $\left(\mathrm{CCl}_{2}, \mathrm{C}-7\right), 58.8(\mathrm{CH}, \mathrm{C}-1), 29.7(\mathrm{CH}, \mathrm{C}-2)$; IR (Film from $\left.\mathrm{CH}_{2} \mathrm{Cl}_{3}\right)$ $U_{\max } 3375,2016,2928,1635,1384,1161,1110,1053,987 \mathrm{~cm}^{-1}$

\section{1,5-Anhydro-2-deoxy-1,2-C-(dichloromethylene)-D-glycero-D-gulo-hexitol} (31)

Compound 30 (626 mg, $1.2 \mathrm{mmol}$ ) was taken up in warm methanol (30 $\mathrm{mL}$ ) under nitrogen flow and $10 \% \mathrm{Pd} / \mathrm{C}(80 \mathrm{mg})$ and three drops of acetic acid were added to the mixture. The reaction vessel was purged with hydrogen gas and the mixture was vigorously stirred for $36 \mathrm{~h}$. The reaction mixture was filtered through celite and concentrated. The crude product was purified by column chromatography (hexanes/ethyl acetate 1:1) resulting in a colourless oil $\mathbf{2 6}$ in a yield of $241.2 \mathrm{mg}(87.5 \%)$.

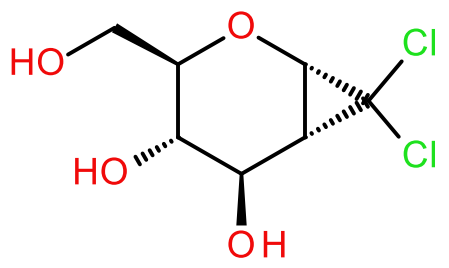

26) $R f=0.05$ (1:1 hexanes/ ethyl acetate) $1 \mathrm{H}$ NMR: $\left(500 \mathrm{MHz}, \mathrm{CDCl}_{3}\right) \delta 3.88(\mathrm{~d}, \mathrm{~J}=8.5 \mathrm{~Hz}, 1 \mathrm{H}, \mathrm{H}-1)$, $3.85(\mathrm{dd}, J=9.0,3.3 \mathrm{~Hz}, 1 \mathrm{H}, \mathrm{H}-4), 3.80$ (d, J = 3.2 $\mathrm{Hz}, 2 \mathrm{H}, \mathrm{H}-6 \mathrm{a}, \mathrm{H}-6 \mathrm{~b}$ ), 3.69- 3.61 ( complex m, 2H, H3, $\mathrm{H}-5), 1.92$ (dd, J = 8.6, 3.3 Hz, 1H, H-2); ${ }^{33} \mathrm{C}$ NMR:

$\left(\mathrm{CDCl}_{3}\right) 80.9(\mathrm{CH}, \mathrm{C}-5), 70.0(\mathrm{CH}, \mathrm{C}-4), 68.9(\mathrm{CH}, \mathrm{C}-3), 62.9\left(\mathrm{CH}_{2}, \mathrm{C}-6\right), 62.0$ $\left(\mathrm{CCl}_{2}, \mathrm{C}-7\right), 58.8(\mathrm{CH}, \mathrm{C}-1), 34.0(\mathrm{CH}, \mathrm{C}-2)$; IR (Film from $\left.\mathrm{CH}_{2} \mathrm{Cl}_{3}\right)$ Umax 3376, $3016,2928,1635,1061,1010,953,785 \mathrm{~cm}^{-1}$ 


\section{Tri-O-benzyl-D-glucal (28)}

A solution of $2(1.54 \mathrm{~g}, 9.72 \mathrm{mmol})$ in dimethylformamide (20 mL) was cooled to $0^{\circ} \mathrm{C}$ and then treated with sodium hydride $(1.5 \mathrm{~g}, 62.5 \mathrm{mmol})$. The solution was stirred at $0{ }^{\circ} \mathrm{C}$ for $25 \mathrm{~min}$, then treated with benzyl bromide $(3 \mathrm{~g}, 37.5 \mathrm{mmol})$ and allowed to warm to room temperature. After $17 \mathrm{~h}$, the solution was quenched with water $(5 \mathrm{~mL})$ and then extracted with diethyl ether $(3 \times 40 \mathrm{~mL})$. The organic fractions were combined, dried, filtered and concentrated to give the crude product 28 as a yellow oil. The crude product was purified by column chromatography (hexanes/ethyl acetate 9:1) resulting in $\mathbf{2 8}$ in a yield of $3.9 \mathrm{~g}(91 \%)$ as a white crystalline solid. The spectral data matched those reported previously (Nagarajan et al. 1997).

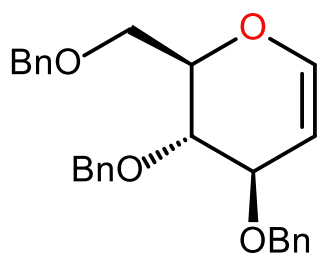

28) $R f=0.35$ (9:1 hexanes/ ethyl acetate); m.p. 53.5$55.0{ }^{\circ} \mathrm{C}$ (lit.107 m.p. $53-55^{\circ} \mathrm{C}$ ); [0] ${ }^{23.4} \mathrm{D}-4.90$ (c 1.02, $\left.\mathrm{CH}_{2} \mathrm{Cl}_{2}\right) ; \quad \mathrm{H}$ NMR: $\left(500 \mathrm{MHz}, \mathrm{CDCl}_{3}\right) \delta \quad 7.33-7.23$ (complex m, 15H, Ph) $6.43(\mathrm{dd}, J=6.1,1.3 \mathrm{~Hz}, 1 \mathrm{H}, \mathrm{H}-1$ ), 4.88 (dd, J = 6.4, 2.7 Hz, 1H, H-2), 4.83 (d, J = 11.3 Hz, 1H, $\left.\mathrm{PhCH}_{2}\right), 4.640\left(\mathrm{~d}, J=11.3 \mathrm{~Hz}, 1 \mathrm{H}, \mathrm{PhCH}_{2}\right), 4.637\left(\mathrm{~d}, J=11.8 \mathrm{~Hz}, 1 \mathrm{H}, \mathrm{PhCH}_{2}\right.$ ), $4.60\left(\mathrm{~d}, J=12.0 \mathrm{~Hz}, 1 \mathrm{H}, \mathrm{PhCH}_{2}\right), 4.564$ (d, J = $12.0 \mathrm{~Hz}, 1 \mathrm{H}, \mathrm{PhCH}_{2}$ ), 4.562 (d, J $=11.8 \mathrm{~Hz}, 1 \mathrm{H}, \mathrm{PhCH}_{2}$ ), 4.61-4.53 (complex $\mathrm{m}, 3 \mathrm{H}, \mathrm{PhCH}_{2}$ ), 4.21 (ddd, $\mathrm{J}=6.4$, 2.7, $1.3 \mathrm{~Hz}, 1 \mathrm{H}, \mathrm{H}-3$ ) , 4.06 (ddd, $J=8.8,5.1,3.0 \mathrm{~Hz}, 1 \mathrm{H}, \mathrm{H}-5$ ), 3.86 (dd, $J=8.8$, $6.1 \mathrm{~Hz}, 1 \mathrm{H}, \mathrm{H}-4), 3.80$ (dd, J=10.5, 5.1 Hz, 1H, H-6a), 3.75 (dd, J = 10.5, 3.0 $\mathrm{Hz}, 1 \mathrm{H}, \mathrm{H}-6 \mathrm{~b}) ;{ }^{13} \mathrm{C}$ NMR: $\left(\mathrm{CDCl}_{3}\right) \delta 144.9(\mathrm{CH}, \mathrm{C}-1), 138.5$ (C, Ph), 138.3 (C, $\mathrm{Ph}), 138.1$ (C, Ph), $128.6(\mathrm{CH}, \mathrm{Ph}), 128.4(\mathrm{CH}, \mathrm{Ph}), 128.1$ (CH, Ph), 127.94 $(\mathrm{CH}, \mathrm{Ph}), 127.89(\mathrm{CH}, \mathrm{Ph}), 127.80(\mathrm{CH}, \mathrm{Ph}), 127.79(\mathrm{CH}, \mathrm{Ph}), 100.1$ (CH, C-2), $76.8(\mathrm{CH}, \mathrm{C}-5), 75.9(\mathrm{CH}, \mathrm{C}-3), 74.5(\mathrm{CH}, \mathrm{C}-4), 73.9\left(\mathrm{CH}_{2}, \mathrm{PhCH}_{2}\right), 73.7\left(\mathrm{CH}_{2}\right.$, $\left.\mathrm{PhCH}_{2}\right), 70.6\left(\mathrm{CH}_{2}, \mathrm{PhCH}_{2}\right)$, $68.7\left(\mathrm{CH}_{2}, \mathrm{C}-6\right)$; IR (Film from $\left.\mathrm{CH}_{2} \mathrm{Cl}_{2}\right)$ : U umax 3087, $3064,3030,2865,1648,1496,1454,1239,1100,1070,1027,735,697 \mathrm{~cm}^{-1}$. 


\section{1,5-Anhydro-3,4,6-tri-O-benzyl-2-deoxy-1,2-C-(dichloromethylene)-D-}

glycero-D-gulo-hexitol (29) and 1,5-anhydro-3,4,6-tri-O-benzyl-2 deoxy 1,2-C-(dichloromethylene)-D-glycero-D-talo-hexitol (30)

As reported by Nagarajan et al. (1997) a solution of 28 (800 mg, 1.93 $\mathrm{mmol}$ ) and benzyltriethylammonium chloride (10 $\mathrm{mg}, 0.04 \mathrm{mmol}$ ) in chloroform (5 mL) was treated drop-wise with a $33 \%$ aqueous solution of sodium hydroxide $(10 \mathrm{~mL})$ with rapid stirring. The biphasic mixture was stirred at room temperature for $10.5 \mathrm{~h}$, diluted with water $(10 \mathrm{~mL})$ and extracted with dichloromethane $(3 \times 20 \mathrm{~mL})$. The organic fractions were combined, dried over magnesium sulphate and concentrated to provide a crude mixture. Which was purified by column chromatography (hexanes/ethyl acetate 14:1) giving 29 as a white solid in $626 \mathrm{mg}$ (62\%) and 30 as a yellow oil in $61.9 \mathrm{mg}(6 \%)$ in a combined yield of $68 \%$. Spectral data matched those which have been previously reported (Nagarajan et al. 1997).

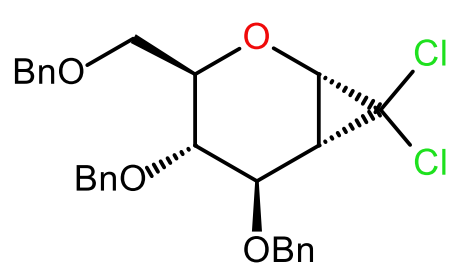

29) $R f=0.40 \quad(9: 1$ hexanes/ ethyl acetate $\left(\mathrm{CH}_{2} \mathrm{Cl}_{2}\right)$; ' $\mathrm{H}$ NMR: $\left(500 \mathrm{MHz}, \mathrm{CDCl}_{3}\right) \delta$ 7.43-7.22 (complex m, 15H, Ph), 4.90 (d, J = $11.2 \mathrm{~Hz}, 1 \mathrm{H}$, $\left.\mathrm{PhCH}_{2}\right), 4.80\left(\mathrm{~d}, J=11.7 \mathrm{~Hz}, 1 \mathrm{H}, \mathrm{PhCH}_{2}\right), 4.69$ (d, J $\left.=11.7 \mathrm{~Hz}, 1 \mathrm{H}, \mathrm{PhCH}_{2}\right), 4.55\left(\mathrm{~d}, J=11.2 \mathrm{~Hz}, 1 \mathrm{H}, \mathrm{PhCH}_{2}\right), 4.53(\mathrm{~d}, J=12.2 \mathrm{~Hz}$, $1 \mathrm{H}, \mathrm{PhCH}_{2}$ ), $4.44\left(\mathrm{~d}, J=12.2 \mathrm{~Hz}, 1 \mathrm{H}, \mathrm{PhCH}_{2}\right), 3.89$ (d, J = $\left.8.0 \mathrm{~Hz}, 1 \mathrm{H}, \mathrm{H}-1\right), 3.84$ $(\mathrm{m}, 1 \mathrm{H}, \mathrm{H}-5), 3.78-3.76$ (complex m, 2H, H-3,4), 3.56 (dd, J = 10.6, $2.8 \mathrm{~Hz}, 1 \mathrm{H}$, $\mathrm{H}-6 \mathrm{a}), 3.52$ (dd, $J=10.6,3.7 \mathrm{~Hz}, 1 \mathrm{H}, \mathrm{H}-6 \mathrm{~b}), 1.79(\mathrm{~m}, 1 \mathrm{H}, \mathrm{H}-2) ;{ }^{13} \mathrm{C}$ NMR: $\left(\mathrm{CDCl}_{3}\right) \delta 138.3$ (C, Ph), 138.1 (C, Ph), 137.8 (C, Ph), 128.65 (CH, Ph), 128.58 $(\mathrm{CH}, \mathrm{Ph}), 128.5(\mathrm{CH}, \mathrm{Ph}), 128.3(\mathrm{CH}, \mathrm{Ph}), 128.04(\mathrm{CH}, \mathrm{Ph}), 128.02(\mathrm{CH}, \mathrm{Ph})$, $127.93(\mathrm{CH}, \mathrm{Ph}), 127.89(\mathrm{CH}, \mathrm{Ph}), 127.8(\mathrm{CH}, \mathrm{Ph}), 80.0(\mathrm{CH}, \mathrm{C}-5), 77.6$ and $75.3(\mathrm{CH}, \mathrm{C}-3$, and $\mathrm{CH}, \mathrm{C}-4), 74.7\left(\mathrm{CH}_{2}, \mathrm{PhCH}_{2}\right), 73.5\left(\mathrm{CH} 2, \mathrm{PhCH}_{2}\right), 72.0$ $\left(\mathrm{CH}_{2}, \mathrm{PhCH}_{2}\right), 70.3(\mathrm{CH} 2, \mathrm{C}-6), 61.6(\mathrm{C}, \mathrm{C}-7), 59.1(\mathrm{CH}, \mathrm{C}-1), 34.4(\mathrm{CH}, \mathrm{C}-2)$; IR (Film from $\mathrm{CH}_{2} \mathrm{Cl}_{2}$ ) U max 3088, 3064, 3031, 2862, 1496, 1454, 1363, 1251, $1093,1026,733,696 \mathrm{~cm}^{-1}$. 


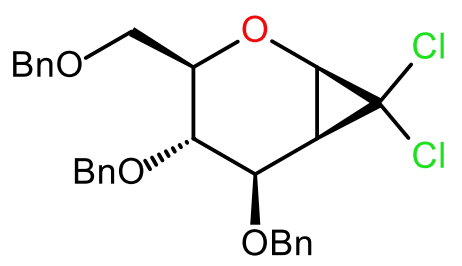

30) $R f=0.25$ (9:1 hexanes/ ethyl acetate); ${ }^{1 H}$ NMR: (500 MHz, $\mathrm{CDCl}_{3}$ ) $\delta$ 7.46-7.17 (complex m, $15 \mathrm{H}, \mathrm{Ph}), 4.89$ (d, J = $\left.11.7 \mathrm{~Hz}, 1 \mathrm{H}, \mathrm{PhCH}_{2}\right), 4.83$ (d, $\left.J=11.0 \mathrm{~Hz}, 1 \mathrm{H}, \mathrm{PhCH}_{2}\right), 4.72(\mathrm{~d}, J=11.7 \mathrm{~Hz}, 1 \mathrm{H}$, $\left.\mathrm{PhCH}_{2}\right), 4.64\left(\mathrm{~d}, J=12.0 \mathrm{~Hz}, 1 \mathrm{H}, \mathrm{PhCH}_{2}\right), 4.56(\mathrm{~d}, J$ $\left.=12.0 \mathrm{~Hz}, 1 \mathrm{H}, \mathrm{PhCH}_{2}\right), 4.55\left(\mathrm{~d}, J=11.0 \mathrm{~Hz}, 1 \mathrm{H}, \mathrm{PhCH}_{2}\right.$ ), 4.18 (apparent $\mathrm{t}, \mathrm{J}=$ $7.8 \mathrm{~Hz}, 1 \mathrm{H}, \mathrm{H}-3), 4.00(\mathrm{~d}, J=8.1 \mathrm{~Hz}, 1 \mathrm{H}, \mathrm{H}-1), 3.86$ (dd, $J=10.3,7.6 \mathrm{~Hz}, 1 \mathrm{H}, \mathrm{H}-$ 4), 3.77 (dd, $J=11.0,1.9 \mathrm{~Hz}, 1 \mathrm{H}, \mathrm{H}-6 \mathrm{a}$ ), 3.67 (dd, $J=11.0,5.3 \mathrm{~Hz}, 1 \mathrm{H}, \mathrm{H}-6 b$ ), 3.48 (ddd, $J=10.3,5.3,1.9 \mathrm{~Hz}, 1 \mathrm{H}, \mathrm{H}-5$ ), 2.13 (apparent $\mathrm{t}, J=8.1 \mathrm{~Hz}, 1 \mathrm{H}, \mathrm{H}-$ 2); ${ }^{13} \mathrm{C} \mathrm{NMR:}\left(\mathrm{CDCl}_{3}\right) \delta 138.3$ (C, Ph), 138.2 (C, Ph), 137.9 (C, Ph), 128.7 (CH, $\mathrm{Ph}), 128.6(\mathrm{CH}, \mathrm{Ph}), 128.53(\mathrm{CH}, \mathrm{Ph}), 128.49(\mathrm{CH}, \mathrm{Ph}), 128.2(\mathrm{CH}, \mathrm{Ph}), 128.1$ $(\mathrm{CH}, \mathrm{Ph}), 128.0(\mathrm{CH}, \mathrm{Ph}), 127.9(\mathrm{CH}, \mathrm{Ph}), 127.7(\mathrm{CH}, \mathrm{Ph}), 78.6(\mathrm{CH}, \mathrm{C}-5), 78.0$ $(\mathrm{CH}, \mathrm{C}-3), 76.8(\mathrm{CH}, \mathrm{C}-4), 74.9\left(\mathrm{CH}_{2}, \mathrm{PhCH}_{2}\right), 73.7\left(\mathrm{CH} 2, \mathrm{PhCH}_{2}\right), 71.4(\mathrm{CH} 2$, $\left.\mathrm{PhCH}_{2}\right), 69.1\left(\mathrm{CH}_{2}, \mathrm{C}-6\right), 62.4(\mathrm{CH}, \mathrm{C}-1), 61.8(\mathrm{C}, \mathrm{C}-7), 32.9(\mathrm{CH}, \mathrm{C}-2)$; IR (Film from $\left.\mathrm{CH}_{2} \mathrm{Cl}_{2}\right) U_{\max } 3088,3064,3031,2917,2862,1496,1454,1364,1091,1026$, $731,696 \mathrm{~cm}^{-1}$.

\section{1,5-Anhydro-3,4,6-tri-O-benzyl-2-deoxy-1,2-C-(dibromomethylene)-D-} glycero-D-gulo-hexitol (32) and 1,5-anhydro-3,4,6-tri-O-benzyl-2deoxy 1,2-C-(dibromomethylene)-D-glycero-D-talo-hexitol (33)

As reported by Nagarajan et al. (1997()a solution of 28 (800 mg, 1.93 mmol) and TEBAC (10 mg, $0.04 \mathrm{mmol}$ ) in bromoform (5 mL) was treated drop-wise with a solution of $33 \%$ aqueous sodium hydroxide $(5 \mathrm{~mL})$, and potassium fluoride $(10 \mathrm{mg}, 0.17 \mathrm{mmol}$ ) in water $(1 \mathrm{~mL})$. The biphasic mixture was stirred at r.t. for three days. The solution was diluted with water $(5 \mathrm{~mL})$ and extracted with diethyl ether $(3 \times 20 \mathrm{~mL})$, then the organic fractions were combined and washed with brine $(30 \mathrm{~mL})$. The solution was dried, over magnesium sulphate and concentrated to provide a crude mixture in bromoform and purified by column chromatography (hexanes/ethyl acetate 14:1) gave $\mathbf{3 2}$ as a white solid in $497 \mathrm{mg}(65 \%)$ and $\mathbf{3 3}$ as a yellow 
oil in $159 \mathrm{mg}(14 \%)$ in a combined yield of $79 \%$. Spectral data matched those which have been previously reported (Moore 2012).

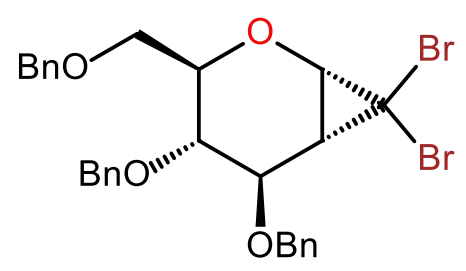

32: $R f=0.40$ (9:1 hexanes/ethyl acetate); m.p. 60.5-62.0 ${ }^{\circ} \mathrm{C}$ $\mathrm{H}$ NMR: $\left(500 \mathrm{MHz}, \mathrm{CDCl}_{3}\right.$ ) $\delta 7.47-$ 7.22 (complex m, 15H, Ph), 4.90 (d, J = $11.2 \mathrm{~Hz}$, $\left.1 \mathrm{H}, \mathrm{PhCH}_{2}\right), 4.81$ (d, J = $\left.12.0 \mathrm{~Hz}, 1 \mathrm{H}, \mathrm{PhCH}_{2}\right), 4.70$ (d, $\left.J=12.0 \mathrm{~Hz}, 1 \mathrm{H}, \mathrm{PhCH}_{2}\right), 4.534(\mathrm{~d}, J=11.2 \mathrm{~Hz}$,

$\left.1 \mathrm{H}, \mathrm{PhCH}_{2}\right), 5.527\left(\mathrm{~d}, J=12.2 \mathrm{~Hz}, 1 \mathrm{H}, \mathrm{PhCH}_{2}\right), 4.44(\mathrm{~d}, J=12.2 \mathrm{~Hz}, 1 \mathrm{H}$, $\mathrm{PhCH}_{2}$ ), 3.95 (d, J = 7.8 Hz, 1H, H-1), 3.87 (ddd, J = 7.6, 3.7, 2.7 Hz, 1H, H-5), 3.79 (dd, $97 \mathrm{~J}=9.5,7.6 \mathrm{~Hz}, 1 \mathrm{H}, \mathrm{H}-4), 3.68(\mathrm{dd}, J=9.5,4.9 \mathrm{~Hz}, 1 \mathrm{H}, \mathrm{H}-3), 3.55$ (dd, $J=10.5,2.7 \mathrm{~Hz}, 1 \mathrm{H}, \mathrm{H}-6 \mathrm{a}$ ), 3.51 (dd, $J=10.5,3.7 \mathrm{~Hz}, 1 \mathrm{H}, \mathrm{H}-6 \mathrm{~b}$ ), 1.87 (dd, $J=7.8,4.9 \mathrm{~Hz}, 1 \mathrm{H}, \mathrm{H}-2) ;{ }^{13} \mathrm{C}$ NMR: $\delta\left(\mathrm{CDCl}_{3}\right) \mathrm{C} 138.3$ (C, Ph), 138.1 (C, Ph), 137.9 (C, Ph), $128.7(\mathrm{CH}, \mathrm{Ph}), 128.6(\mathrm{CH}, \mathrm{Ph}), 128.51(\mathrm{CH}, \mathrm{Ph}), 128.3(\mathrm{CH}$, $\mathrm{Ph}), 128.03(\mathrm{CH}, \mathrm{Ph}), 128.01(\mathrm{CH}, \mathrm{Ph}), 127.94(\mathrm{CH}, \mathrm{Ph}), 127.88(\mathrm{CH}, \mathrm{Ph})$, $127.81(\mathrm{CH}, \mathrm{Ph}), 80.4(\mathrm{CH}, \mathrm{C}-5), 80.1(\mathrm{CH}, \mathrm{C}-3), 75.2(\mathrm{CH}, \mathrm{C}-4), 74.8\left(\mathrm{CH}_{2}\right.$, $\left.\mathrm{PhCH}_{2}\right), 73.5\left(\mathrm{CH}_{2}, \mathrm{PhCH}_{2}\right), 71.9\left(\mathrm{CH}_{2}, \mathrm{PhCH}_{2}\right), 70.3(\mathrm{CH} 2, \mathrm{C}-6), 59.4(\mathrm{CH}, \mathrm{C}-$ 1), $35.4\left(\mathrm{CH}, \mathrm{C}\right.$ 2), 34.1 (C, C-7); IR (Film from $\mathrm{CH}_{2} \mathrm{Cl}_{2}$ ): U max 3063, 3030, 2860, $1496,1454,1092,1027,734,696 \mathrm{~cm}^{-1}$.

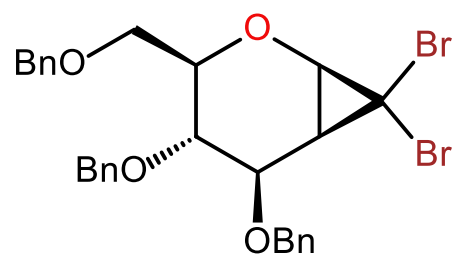

33) $\operatorname{Rf}=0.25$ (9:1 hexanes/ethyl acetate); $\mathrm{l} \mathrm{H}$ NMR: (500 MHz, $\mathrm{CDCl}_{3}$ ) $\delta$ 7.50-7.18 (complex m, $15 \mathrm{H}, \mathrm{Ph}), 4.92\left(\mathrm{~d}, J=11.7 \mathrm{~Hz}, 1 \mathrm{H}, \mathrm{PhCH}_{2}\right), 4.83$ (d, $\left.J=11.1 \mathrm{~Hz}, 1 \mathrm{H}, \mathrm{PhCH}_{2}\right), 4.72(\mathrm{~d}, J=11.7 \mathrm{~Hz}, 1 \mathrm{H}$, $\left.\mathrm{PhCH}_{2}\right), 4.67\left(\mathrm{~d}, J=12.1 \mathrm{~Hz}, 1 \mathrm{H}, \mathrm{PhCH}_{2}\right), 4.57(\mathrm{~d}, J$ $\left.=12.1 \mathrm{~Hz}, 1 \mathrm{H}, \mathrm{PhCH}_{2}\right), 4.56\left(\mathrm{~d}, J=11.1 \mathrm{~Hz}, 1 \mathrm{H}, \mathrm{PhCH}_{2}\right), 4.18(\mathrm{t}, J=7.8 \mathrm{~Hz}, 1 \mathrm{H}$, $\mathrm{H}-3$ ), 4.08 (d, J = 7.8 Hz, 1H, H-1), 3.96 (dd, J = 10.3, 7.4 Hz, 1H, H-4), 3.78 (dd, $J=11.0,1.7 \mathrm{~Hz}, 1 \mathrm{H}, 1 \mathrm{H}, \mathrm{H}-6 \mathrm{a}$ ), 3.68 (dd, $J=11.0,5.4 \mathrm{~Hz}, 1 \mathrm{H}, \mathrm{H}-6 \mathrm{~b}$ ), 3.52 (ddd, $J=10.3,5.4,1.7 \mathrm{~Hz}, 1 \mathrm{H}, \mathrm{H}-5$ ), 2.29 (apparent $t, J=7.9 \mathrm{~Hz}, 1 \mathrm{H}, \mathrm{H}-2$ ); ${ }^{13} \mathrm{C}$ NMR: $\left(\mathrm{CDCl}_{3}\right) \delta 138.3$ (C, Ph), 138.2 (C, Ph), 137.9 (C, Ph), 128.7 (CH, Ph), 128.4 $(\mathrm{CH}, \mathrm{Ph}), 128.2(\mathrm{CH}, \mathrm{Ph}), 128.1(\mathrm{CH}, \mathrm{Ph}), 128.0(\mathrm{CH}, \mathrm{Ph}), 127.83(\mathrm{CH}, \mathrm{Ph})$, $127.79(\mathrm{CH}, \mathrm{Ph}), 127.7(\mathrm{CH}, \mathrm{Ph}), 78.6(\mathrm{CH}, \mathrm{C}-3), 78.5(\mathrm{CH}, \mathrm{C}-5), 76.6(\mathrm{CH}, \mathrm{C}-$ 4), $74.8\left(\mathrm{CH}_{2}, \mathrm{PhCH}_{2}\right), 73.7\left(\mathrm{CH}_{2}, \mathrm{PhCH}_{2}\right), 71.1\left(\mathrm{CH}_{2}, \mathrm{PhCH}_{2}\right), 69.1\left(\mathrm{CH}_{2}, \mathrm{C}-6\right)$, 
$62.8(\mathrm{CH}, \mathrm{C}-1), 33.8(\mathrm{CH}, \mathrm{C}-2), 30.9(\mathrm{C}, \mathrm{C}-7) ; \mathrm{IR}$ (Film from $\left.\mathrm{CH}_{2} \mathrm{Cl}_{2}\right)$ : Umax 3063, 3030, 2861, 1496, 1454, 1091, 1027, 734, $696 \mathrm{~cm}^{-1}$.

\section{3-(prop-2-ynylamino)propan-1-ol (34)}

A solution of 3-aminopropanol (1 g, $0.013 \mathrm{~mol})$ and $\mathrm{K}_{2} \mathrm{CO}_{3}(1.8 \mathrm{~g}, 0.013$ $\mathrm{mol}$ ) in acetonitrile $\left(45 \mathrm{~mL}\right.$ ) was stirred at r.t. under $\mathrm{N}_{2}$ for $5 \mathrm{~min}$. A solution of propargyl bromide $(0.158 \mathrm{~g}, 0.0013 \mathrm{~mol})$ dissolved in acetonitrile $(6 \mathrm{~mL})$ was added drop-wise with stirring. After stirring for $24 \mathrm{~h}$ the solvent was evaporated. The residue was dissolved in ethyl acetate $(60 \mathrm{~mL})$, washed with $10 \%$ sodium hydroxide in (3x $25 \mathrm{~mL}$ ) and dried, over magnesium sulphate and concentrated. The crude product was purified by colunm chromatography (ethyl acetate to dichloromethane/methanol 4:1) to give 34 (146 mg (98.6\%).

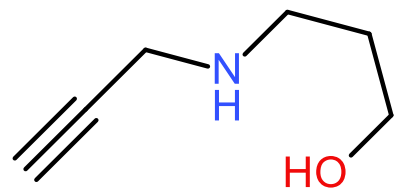

34) $R f=0.20\left(4: 1 \mathrm{CH}_{2} \mathrm{Cl}_{2} / \mathrm{MeOH}\right) ;{ }^{1} \mathrm{H}$ NMR: $(300 \mathrm{MHz}$, $\left.\mathrm{CDCl}_{3}\right) \delta 3.80(\mathrm{t}, J=5.4 \mathrm{~Hz}, 2 \mathrm{H}, \mathrm{H}-1), 3.45(\mathrm{~d}, J=2.5$ $\mathrm{Hz}, 2 \mathrm{H}, \mathrm{H}-4), 2.95(\mathrm{t}, J=5.8 \mathrm{~Hz}, 2 \mathrm{H}, \mathrm{H}-3), 2.45(\mathrm{bs}, 1 \mathrm{H}$, $\mathrm{OH}), 2.23(\mathrm{t}, J=1.5 \mathrm{~Hz}, 1 \mathrm{H}, \mathrm{H}-5), 1.73(\mathrm{p}, J=5.9,11.2$ $\mathrm{Hz}, 2 \mathrm{H}, \mathrm{H}-2) ;{ }^{13} \mathrm{C}$ NMR:

\section{3-(prop-2-ynylamino)propan-1-ol derivatised sepharose (35)}

To a solution of $\mathrm{N}$-propargyl-3-aminopropanol (126 mg, $1.1 \mathrm{mmol}$ ) in tetrahydrofuran $(3 \mathrm{~mL})$ and $\mathrm{dH}_{2} \mathrm{O}(4 \mathrm{~mL})$ was added epoxy-activated sepharose matrix $(600 \mathrm{mg})$. The mixture was shaken at $33^{\circ} \mathrm{C}$ for $16 \mathrm{~h}$ before the mixture was centrifuged down at $2000 \mathrm{rpm}$ for $1 \mathrm{~min}$. The solvent was decanted off, and ethanol ( $6 \mathrm{~mL}$ ) was added. The ethanol mixture was vortex for $1 \mathrm{~min}$ then centrifuged at $2000 \mathrm{rpm}$ for $1 \mathrm{~min}$, the solvent was decanted and replaced with diethyl ether $(6 \mathrm{~mL})$. The solution was vortex for $1 \mathrm{~min}$ then centrifuged at $2000 \mathrm{rpm}$ for $1 \mathrm{~min}$ before the 
solvent being decanted, this last step was repeated. The resulting matrix was further dried under vacuum.

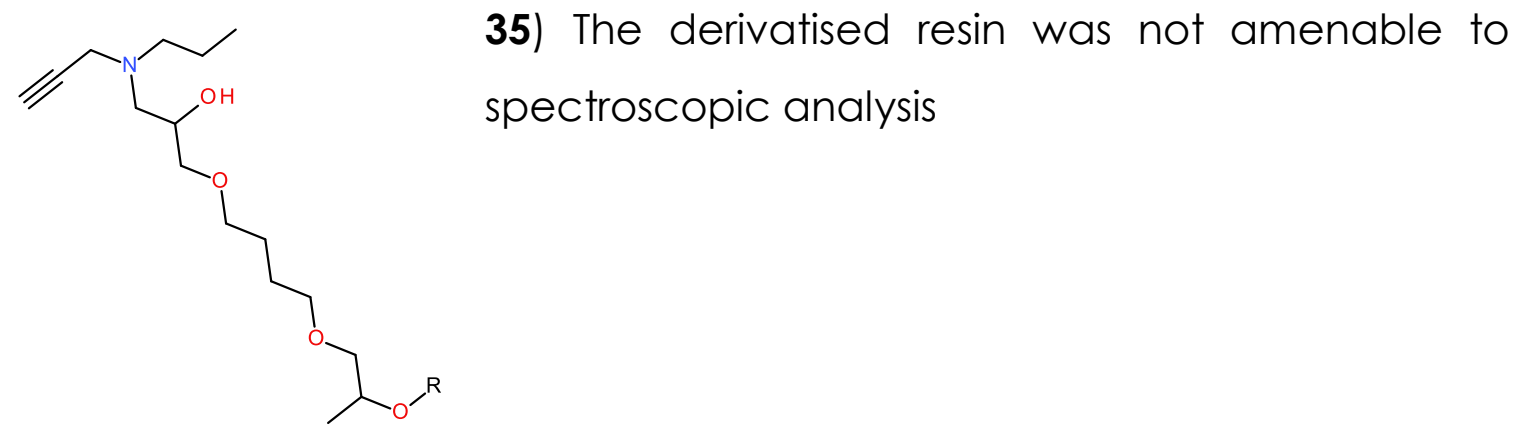

\section{1,5-Anhydro-3,4-di-O-benzoyl-2-deoxy-6-O-trityl-D-arabino-hex-1-enitol} (36) and 1,5-Anhydro-4-O-benzoyl-2-deoxy-6-O-trityl-D-arabino-hex-1enitol (37)

To a solution of $2(4.0 \mathrm{~g}, 10.3 \mathrm{mmol})$ in dimethylformamide $(32 \mathrm{~mL})$ and pyridine $(4 \mathrm{~mL})$ at $0{ }^{\circ} \mathrm{C}$ was slowly added benzoyl chloride $(1.14 \mathrm{~g}, 8.11$ $\mathrm{mmol})$. The solution was then stirred at r.t. for $4 \mathrm{~h}$, diluted with water $(5 \mathrm{~mL})$, and extracted with dichloromethane, dried over magnesium sulphate and concentrated. The crude product was purified by column chromatography (hexanes/ethyl acetate 3:1) to

afford 36 in $3.57 \mathrm{~g}(80 \%)$ and 37 in $0.40 \mathrm{~g}(8 \%)$. The spectral data matched those reported in the literature (Mariela \& Kulkarni, 1988).

To a solution of $2(1 \mathrm{~g}, 2.57 \mathrm{mmol})$ in dimethylformamide $(8 \mathrm{~mL})$ and pyridine $(1 \mathrm{~mL})$ at $0{ }^{\circ} \mathrm{C}$ was slowly added benzoyl chloride $(0.9 \mathrm{~g}, 6.43$ mmol). The solution was then stirred at r.t. for $4 \mathrm{~h}$, diluted water, and extracted with dichloromethane, dried over magnesium sulphate and concentrated. The crude product was purified by column chromatography (hexanes/ethyl acetate 3:1) to afford 37 in $3.66 \mathrm{~g}(95 \%)$. 
<smiles>O=C(O)[C@H]1C=CO[C@@H](CO[Tl])[C@@H]1O</smiles>

36) 'H NMR: (500 MHz, CD $\left.{ }_{3} \mathrm{OD}\right) \delta$ 8.34- 7.06 (m, 25H, Ph), $6.6(a p p d d, 1 H, H-1), 5.73(t, 1 \mathrm{H}, J=6.1 \mathrm{~Hz}, \mathrm{H}-4), 5.62$ (ddd, $1 \mathrm{H}, J=6.1,1.8 \mathrm{~Hz}, \mathrm{H}-3$ ), 5.04 (dd, $1 \mathrm{H}, J=6.1,3.2$ $\mathrm{Hz}, \mathrm{H}-2)$, 4.54- $4.27(\mathrm{~m}, \mathrm{lH}, \mathrm{H}-5), 3.51-3.57$ (m, 2H, H-6a \& H-6b); ${ }^{13} \mathrm{C}$ NMR: $\left(\mathrm{CDCl}_{3}\right) \delta 168.2$ (C, OCOPh), 162.6 (OCOPh), $142.8(\mathrm{CH}, \mathrm{Ph}), 134.6(\mathrm{CH}, \mathrm{Ph}), 133.1$ (CH, Ph), $130.6(\mathrm{CH}, \mathrm{Ph})$, $128.8(\mathrm{CH}, \mathrm{Ph}), 127.8(\mathrm{CH}, \mathrm{Ph}), 127.3(\mathrm{CH}, \mathrm{Ph}), 127.0(\mathrm{CH}, \mathrm{Ph}), 98.7(\mathrm{CH}, \mathrm{C}-$ 2), $87.1\left(\mathrm{C}, \mathrm{CPh}_{3}\right), 76.1(\mathrm{CH}, \mathrm{C}-5), 68.4(\mathrm{CH}, \mathrm{C}-4) 68.2(\mathrm{CH}, \mathrm{C}-3), 62.1\left(\mathrm{CH}_{2}\right.$, C-6).

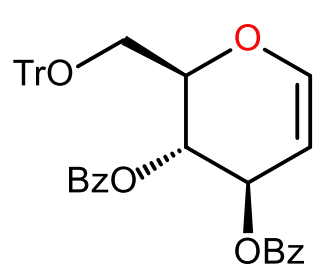

37) 'H NMR: $\left(500 \mathrm{MHz}, \mathrm{CD}_{3} \mathrm{OD}\right) \delta$ 7.80- $7.10(\mathrm{~m}, 2 \mathrm{H}$, $\mathrm{Ph}$ ), 6.55 (dd, $1 \mathrm{H}, \mathrm{H}-1$ ), 5.55 (ddd, $1 \mathrm{H}, 4.8,1.8 \mathrm{~Hz}, \mathrm{H}-3$ ), $4.90(\mathrm{dd}, 1 \mathrm{H}, \mathrm{J}=6.0,3.4 \mathrm{~Hz}, \mathrm{H}-2), 3.81-4.0(\mathrm{~m}, 2 \mathrm{H}, \mathrm{H}-4, \mathrm{H}-$ 5), 3.33 (dd 1H, H-6a), 3.64 (dd, 1H, H-6b) 2.42 (bs, OH); ${ }^{13} \mathrm{C}$ NMR: $\left(\mathrm{CDCl}_{3}\right) \delta 168.2$ (OCOPh), 146.8 (CH, Ph), 144.1 (CH, Ph), 133.6 $(\mathrm{CH}, \mathrm{Ph}), 130.8(\mathrm{CH}, \mathrm{Ph}), 129.1(\mathrm{CH}, \mathrm{Ph}), 128.3(\mathrm{CH}, \mathrm{Ph}), 128.2(\mathrm{CH}, \mathrm{Ph})$, $127.4(\mathrm{CH}, \mathrm{Ph}), 99.7(\mathrm{CH}, \mathrm{C}-2), 87.4\left(\mathrm{C}, \mathrm{CPh}_{3}\right), 78.1(\mathrm{CH}, \mathrm{C}-5), 73.4(\mathrm{CH}, \mathrm{C}-4)$ $68.2(\mathrm{CH}, \mathrm{C}-3), 63.1\left(\mathrm{CH}_{2}, \mathrm{C}-6\right)$. 


\subsection{BIOLOGY}

\subsection{Aims and objectives}

The overall aim of the biology study is to identify the most active cyclopropane-containing glycoside and its cellular protein target. To achieve this, objectives listed will be completed.

- Conduct a structure activity relationship (SAR) analysis to determine the most active compound against $S$. cerevisiae (2);

- Identify potential pathways of interactions by chemical genomics (3); and

- Determine protein targets by mass spectrometry (4).

This chapter describes the biological testing of the compounds synthesised in chapter 2. The library of compounds will be subjected to initial dose response assays in vivo, (S. cerevisiae) to determine the lead compound, which will also give evidence of the mechanism of action. The lead compound will be then used in the chemical genomic screen, to determine pathways or interactions within the cell. Finally, modifications will be made to the lead compound to isolate the biological target.

Note. Compound $\mathbf{7}$ will now be called benzose from here on. 


\subsection{Introduction}

\subsubsection{Structure Activity Relationship}

The purpose and importance of a Structure Activity Relationship (SAR) is to predict the properties of new compounds from similar known pre-existing molecules.

In the context of bioactive compounds, SARs are relationships between the molecular structure and biological activity of chemicals. Similarity can be assessed by structure or quantitatively by determining the mathematical relationships between molecular descriptors and activity of the compound. Studies of the latter are called quantitative structure activity relationships (QSAR). This thesis will focus on SAR not QSAR. The basic idea of SAR studies originated in the 19th century, when a study by Crum-Brown and Fraser (1868) indirectly discovered that it was the quaternary ammonium group of curare and other quaternary alkaloids that was responsible for their activity of muscular paralysis.

The first direct attempt to identify the relationship between pharmacological effect and physicochemical properties was described by Richet in 1893. Richet's study identified the effect of narcotic action on tadpoles by a class of organic compounds was related to the solubility of these compounds. Since these early studies, the ideas of SAR have stayed the same, but the uses have continued to be developed. SAR-based studies have been used to great effect in finding new drug candidates (Baumert et al. 2012). SAR can also be used to suggest a likely mechanism of action; by no means can it definitively determine the mechanism of action but it can give supporting evidence. The rationale behind determining the mechanism of reaction comes from an in-depth knowledge of the chemistry of the substituents. For example, some reactions are able to proceed via a chlorine-containing compound whereas the reaction is less favourable with bromine at the same position. 
The rate of the reaction is determined by the stability of the anion intermediate; the compound that has the most stabilised intermediate can facilitate the reaction most effectively. With an understanding of the chemistry it is possible to take a range of similar compounds and determine a proposed mechanism; this is further demonstrated in section 3.5.2.

\subsubsection{Affinity isolation}

The early applications of affinity matrices were related to the use of "immunoadsorbents" for the purification of antibodies. These early applications have also been used for the purification of nucleotides, complimentary strands of nucleic acids, certain species of transfer RNA and enzymes (Silman \& Katchalski, 1966; Sander et al. 1966; Cuatrecasas, 1970). It was not until later that enzyme isolation started to have a huge impact in this field.

Affinity chromatography matrices attached to bioactive compounds are a major tool for finding direct targets. The identification of target proteins for bioactive compounds is an essential process of modern pharmaceutical drug development because it is a prelude to identification of novel drugs with greater selectivity through mechanismbased and structure-based design. Traditionally for this method, compounds that are bound to the matrix interact with proteins by noncovalent interactions. However, if a matrix-bound bioactive compound covalently binds to a target protein, it is believed this protein can be removed by trypsin digestion off the matrix-bound protein. The peptide fragments can then be identified using MALDI-TOF analysis; an ionization technique used in mass spectrometry, allowing the analysis of molecules. 
The bioactive compound can be either attached to the matrix before or after it has interacted with proteins. If attached after, the chemical reaction of attaching the molecule and matrix must not affect any potential protein targets. Figure 3.1 by Speers \& Cravatt (2004) demonstrates the binding of a matrix to a compound to identify the molecule's target. The compound, with either an azide or alkyne attached can be either added to cells or it can be added to a cell lysate. The matrix is then attached in the lysate under the Huisgen Cyclisation conditions (copper sulphate, neutralised ascorbic acid).

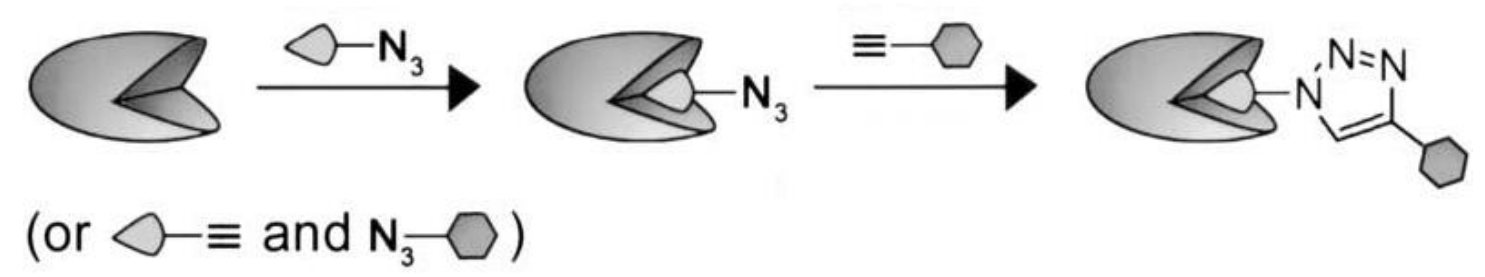

Figure 3.1. Cartoon representation of an azide-containing molecule binding to an enzyme then the attachment to an alkyne-substituted matrix (Speers \& Cravatt 2004). The biologically active compound is first treated with a protein lysate, selectively binding a protein. The bound protein is then removed from the lysate by attaching it to a resin through a Huisgen Cyclisation with the alkyne. This resulting in the bioactive compound being irreversibly attached to the resin.

\subsubsection{Yeast gene deletion sets (Saccharomyces cerevisiae)}

The yeast gene deletion set (YDS) provides one of the most successful methods used in the identification of pathways affected by small drug-like compounds (Parsons et al. 2004). For S. cerevisiae, deletion mutations have been made for all $\sim 6300$ known or suspected genes, identifying 1000 essential yeast genes and 4800 viable haploid gene-deletion mutants (Tong et al. 2004). These findings show yeast has the ability to withstand deletions of a substantial number of individual genes and remain viable in standard laboratory conditions (Suter et al. 2006). While 
many single gene deletions cause no change in growth, combinations of two such deletions can lead to reduction in, or loss of, viability (Boone et al. 2007).

Synthetic non-viable relationships may occur for genes acting in a single process, for example, two pathways with the same end point (Boone et al. 2007). To enable high-throughput synthetic lethal analysis of a bioactive compound, a library with a single deletion can be used, while the bioactive compound acts equivalently to a second deletion. The deletion strains that die or have decreased growth will identify potential pathways that are involved in the bioactivity of the compound (Boone et al. 2007). Figure 3.2 demonstrates the viability of the deletion strains when exposed to the bioactive compound. In some cases an introduced bioactive compound shows only low levels of activity due to the cell's abilities for detoxification, for example via efflux pumps (Prasad \& Goffeau, 2012). To overcome this it is possible to remove the activity of efflux pumps, by deletion of the genes that encode for them or their transcription factors (Wendler et al. 1997). This provides another example of gene deletions that have no effect until treated with a bioactive compound. Removing the activity of efflux pumps is not the only method for increasing sensitivity of bioactive compounds, for example co-treating bioactive compounds with efflux pump inhibitors. 


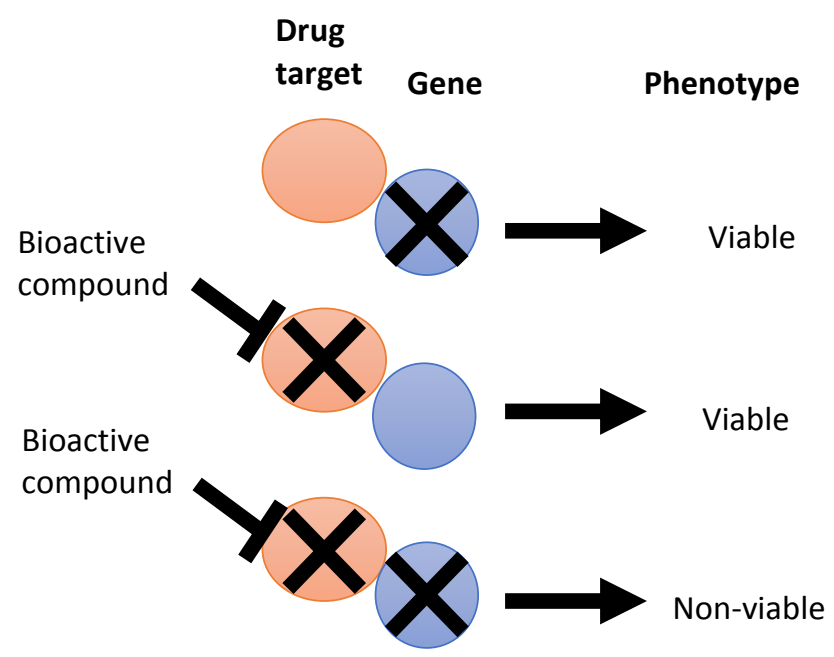

Figure 3.2. A chemical genomic approach to identify drug pathways and interactions. While the cell is viable when either treated with a biologically active compound or related gene is disrupted, it is unable to survive the double insult. By indentifing the pattern of phenotype related to treatment with the biologically active compound in the chemical genomic screen, target pathways and interactions can be identified. (Figure adapted from Parsons et al. 2004)

Double and triple mutants are also possible. The $\Delta p d r 1 \Delta p d r 3 \Delta x x x$ (where xxx donates a single knockout) has been used in our laboratory for drug discovery and pathway identification (Coorey, 2012). The PDR I and PDR3 genes encode transcription factors for $A B C$ transporters including the pdr5p efflux pump, which is able to export a vast range of compounds (Talibi \& Raymond, 1999; Prasad \& Goffeau, 2012). Due to the nature of drug-like compounds, the majority of them are substrates for efflux pumps because of their hydrophobicity (Prasad \& Goffeau, 2012). By removing or reducing efflux pump activity, it is possible to identify lead-drug candidates that would normally be missed in a drug screen.

The gene SYS 1 codes for an integral membrane protein in the golgi and is required for targeting of the ARf-like GTPase Arl3p to the golgi. The deletion of SYSI causes increased sensitivities to many different drug-like compounds (Setty et al. 2004). The SYS1 gene knock out has no effect on cell growth until the cell is put under this type of stress. Gene deletions of this sort that sensitise to multiple drugs or conditions are referred to as multi drug sensitising, or colloquially "frequent fliers" (Hillenmeyer et al. 2008). A 
paper presented by Hillenmeyer et al. (2008) lists the currently known frequent flier genes whose deletion strains are sensitive to many bioactive compounds and therefore are generally ignored in chemical genomic screens.

In this study the triple deletion mutant library ( $\Delta p d r l \Delta p d r 3 \Delta x x x)$ was used as the compounds being tested are exported by $A B C$ transporters in $S$. cerevisiae. 


\subsection{Materials and methods}

\subsubsection{Chemicals and compounds}

The range of cyclopropane-containing glucals were either synthesised by myself (chapter 2.0) or donated by Peter Moore of the Organic Chemistry Group, School of Chemical and Physical Sciences, Victoria University of Wellington, and were purified to $>95 \%$ pure as assessed by NMR spectroscopy. In each case, each study was completed using a single batch apart from the lead compound which was identified by batch number to keep experiments consistent. All samples were stored at $-20^{\circ} \mathrm{C}$ in DMSO at a concentration of either $10 \mathrm{mM}$ or $50 \mathrm{mM}$. All other reagents were purchased from Sigma-Aldrich unless otherwise stated.

\subsubsection{Yeast strains and cultures}

Yeast strains were either obtained from the $\Delta p d r l \Delta p d r 3 \Delta x x x$ knockout library, originally prepared by Namal Coorey (within the Chemical Genetic Group, School of Biological Sciences, Victoria University of Wellington) or from a copy of the yeast gene deletion library, a gift from Charles Boone (University of Toronto, Canada).

\begin{tabular}{|c|c|}
\hline Strain & Genotype \\
\hline BY4741 & $\begin{array}{lll}\text { MATa his } 3 \Delta 0 / \text { his } 3 \Delta 0 & \text { leu2 } \Delta 0 / l e u 2 \Delta 0 & \text { met15 } \Delta 0 / M E T 15 \\
\text { ura } 3 \Delta 0 / \text { ura3 } \Delta 0 & & \end{array}$ \\
\hline$\Delta p d r l \Delta p d r 3$ & $\begin{array}{l}\text { MATa pdrl } \Delta:: \text { natR pdr3 } \Delta:: U R A 3 \text { can } 1 \Delta:: S T E 2 \text { pr-Sp_his5; lyp l } \Delta ; \\
\text { his3 } \Delta \text { l; leu2 } \Delta 0 \text {; ura3 } \Delta 0 ; \text { met15 } \Delta 0 \text { LYS2 }\end{array}$ \\
\hline$\Delta p d r l \Delta p d r 3 \Delta x x x$ & 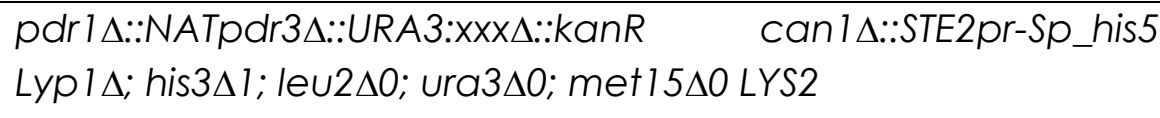 \\
\hline 4XUPRE-GFP & 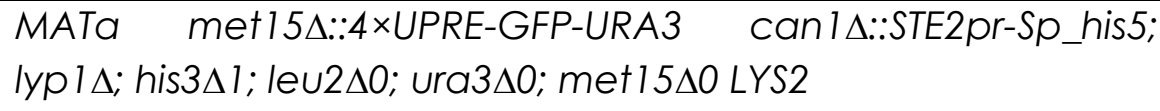 \\
\hline
\end{tabular}




\subsubsection{Yeast growth conditions}

All S. cerevisiae strains were cultured in one of the following media supplemented with appropriate antibiotics when required; ClonNat (WERNER BioAgents) final concentration of $100 \mathrm{mg} / \mathrm{L}$ and geneticin (G418) final concentration $200 \mathrm{mg} / \mathrm{L}$. All media were autoclaved at $121^{\circ} \mathrm{C}$ for 22 min before use.

Yeast peptone dextrose (YPD) Broth: Was prepared from $8 \mathrm{~g}$ yeast extract (Becton, Dickinson and Company), $16 \mathrm{~g}$ Bacto-Peptone (Becton, Dickinson and Company), and $0.096 \mathrm{~g}$ adenine (Sigma-Aldrich) mixed into $760 \mathrm{~mL}$ of distilled water. The resulting mixture was sterilised by autoclave; once cooled, $40 \mathrm{~mL}$ of $40 \%$ glucose (Sigma-Aldrich) solution was added along with appropriate antibiotics when required.

Solid YPD media was prepared as above but with the addition of $16 \mathrm{~g}$ agar (Invitrogen).

Synthetic complete (SC) broth: Was prepared from $1.7 \mathrm{~g}$ of yeast nitrogen base without amino acids or ammonium sulphate (Becton, Dickinson and Company), $1 \mathrm{~g}$ of monosodium glutamate (Sigma-Aldrich), and $2 \mathrm{~g}$ amino acid mixture (see below) was added to $760 \mathrm{~mL}$ of distilled water and sterilized by autoclave. Once called, $40 \mathrm{~mL}$ of $40 \%$ glucose (Sigma-Aldrich) solution was added along with appropriate antibiotics when required.

Solid SC media was prepared as above but with the addition of $16 \mathrm{~g}$ agar (Sigma-Aldrich).

Synthetic Drop out (SD-ura) broth: as above (SC) media with the removal of uracil in the amino acid mixture. 
Amino acid mixture for SC media: $3 \mathrm{~g}$ adenine, $2 \mathrm{~g}$ uracil, 2 inositol, $0.2 \mathrm{~g}$ p-aminobenzoic acid, $2 \mathrm{~g}$ alanine, $2 \mathrm{~g}$ asparagine, $2 \mathrm{~g}$ aspartic acid, $2 \mathrm{~g}$ cysteine, $2 \mathrm{~g}$ glutamic acid, $2 \mathrm{~g}$ glutamine, $2 \mathrm{~g}$ glycine, $2 \mathrm{~g}$ histidine, $2 \mathrm{~g}$ isoleucine, $10 \mathrm{~g}$ leucine, $2 \mathrm{~g}$ lysine, $2 \mathrm{~g}$ methionine, $2 \mathrm{~g}$ phenylalanine, $2 \mathrm{~g}$ proline, $2 \mathrm{~g}$ serine, $2 \mathrm{~g}$ threonine, $2 \mathrm{~g}$ tryptophan, $2 \mathrm{~g}$ tyrosine and $2 \mathrm{~g}$ valine.

\subsubsection{Initial IC $\mathrm{I}_{50}$ assay in Saccharomyces cerevisiae}

\section{Liquid phase assay}

The yeast strains BY4741 wild type and $\Delta p d r 1 \Delta p d r 3$ were used to determine the initial $I C_{50}$ of benzose and compounds $\mathbf{1 - 1 8}$.

With the initial concentration of $1 \mathrm{mM}$, serial dilutions in $-\log (\sqrt{ } 10 \approx 3.162-$ fold) decrements were made for each of the glucal derived compounds by dilution in DMSO (dimethyl sulfoxide). Serial dilutions were transferred to wells in a 96 well V-bottom place (KJ511-3, Interlab) along with DMSO alone for the negative control to determine the residual growth for each yeast strain in the absence of growth inhibitory compound, the residual growth is determined from the treated cell growth divided by the control cell growth.

A single colony of yeast strain of interest (BY4741 or $\Delta p d r 1 \Delta p d r 3$ ) was inoculated in $4 \mathrm{~mL}$ of each of the three broths (YPD, SC, SD) with the appropriate antibiotics. The cultures were incubated on a rotating drum (40 rpm) at $31{ }^{\circ} \mathrm{C}$ for 18 hours. Cell titre was determined using a spectrometer (UNICAM 8625 UV/VIS) and $5 \times 10^{5}$ cells $/ \mathrm{mL}$ were inoculated into $10 \mathrm{~mL}$ of the respective broth for each yeast strain and vortexed. From each broth plus cells, $99 \mu \mathrm{L}$ were delivered into the wells of a 96 well flatbottomed plate (TCP-000-096, JET BIOFIL) using a multichannel pipette, for each strain in each drug condition in triplicate. Subsequently, $2 \mu \mathrm{L}$ of half 
log drug dilutions and DMSO were added to the yeast cells (final DMSO concentration 2\%). Individual rows of SC, SD and YPD were included for each plate to determine the optical density (OD) of the growth media. The contents of the wells were mixed by vortexing the plates at $1000 \mathrm{rpm}$ for 30 seconds using the Eppendorf Mix Mate (Krackeler Scientific Inc. Albany, New York) and were incubated at $30^{\circ} \mathrm{C}$ for 18 hours.

The cultures were resuspended by vortexing at $1000 \mathrm{rpm}$ for 30 seconds and the OD in each well was measured at $590 \mathrm{~nm}$ using Envision ${ }^{\mathrm{TM}}$ XCite $^{\mathrm{TM}}$ 2102 Multilabel Reader (Perkin-Elmer, Turku, Finland) with HTS microplate reader software version 1.12. The OD in each well was subtracted from the average $O D$ for media alone control. The residual growth (OD $590 \mathrm{Exp} /$ $\mathrm{OD}_{590 \mathrm{DMSO}}$ control $\times 100$ ) was determined and the average residual growth plotted using Microsoft Excel (2013).

\section{Solid phase assay}

Hot SC-agar $\left(50^{\circ} \mathrm{C}\right.$ ) was poured into 33 Singer plates (Singer Instruments, Somerset UK), with benzose at a range of concentrations from 0 to $200 \mu \mathrm{M}$, in increments of $20 \mu \mathrm{M}$. In triplicate, a single plate from the $\Delta p d r l \Delta p d r 3 \Delta x x x$ library (384 array) was chosen and plated onto each of the 30 compound-containing agar plates and along with three DMSO alone plates for the negative context by the use of Singer RoToR HDA robot (Singer Instruments, Somerset, UK). The plates were imaged photographically after 24 hours incubation at $30^{\circ} \mathrm{C}$. Visual inspection and use of Colony HT (2006, version 110) were used to identify a concentration that led to $\sim 40 \%$ reduction in colony size compared to control, allowing identification of both resistant and sensitive yeast strains in further assays. 


\subsubsection{Serial dilution assay}

The serial spot dilution assay to determine cytotoxic or cytostatic behaviours was followed directly from the SC liquid phase $\mathrm{IC}_{50}$ experiment of benzose against BY4741 and $\Delta$ pdrl $\Delta$ pdr3 (Methods 3.7.4). One hundred $\mu \mathrm{L}$ of culture from the benzose concentrations: 1000, 314, 100, 31, 10, 3.14, 1.0 and $0.31 \mu \mathrm{M}$ as well as the $2 \%$ DMSO control were transferred into a 96 well plate from which five sets of $1: 4$ serial dilutions in $\mathrm{dH}_{2} \mathrm{O}$ were made. The 96 well plates were then transfered onto SC agar plates by pipetting $1.5 \mu \mathrm{L}$ of each dilution with a multi-channel pipette. This resulted in four lines of five serial dilutions on each half of the SC agar plate as shown below. The agar plates were incubated at $30^{\circ} \mathrm{C}$ for 36 hours. Photographs were recorded at 18, 24 and 36 hours.

\subsubsection{Mammalian cell experiments}

All mammalian cell based experiments were completed by Arun Kanakkantharan in the School of Biological Science, Victoria University of Wellington.

MTT Cell proliferation assay

1A9 human ovarian carcinoma cells and HL-60 human promyelocytic leukemia cells were seeded in 96-well plates at $1 \times 10^{4}$ cells/well and incubated with benzose for 48 hours (for HL-60 cells) and 72 hours (for 1A9 cells) under normal cell culture conditions. Twenty microlitres of MTT was added to each well and incubated for two hours at $37^{\circ} \mathrm{C}$. The blue crystals were then solubilized at $37^{\circ} \mathrm{C}$ overnight in $100 \mu \mathrm{L}$ of solubilizing solution containing $10 \%$ SDS, $45 \%$ dimethylformamide $(\mathrm{pH} 4.5$, adjusted with acetic acid), and MTT reduction was measured the following day by absorbance at a wavelength of $570 \mathrm{~nm}$ in a multiwell-plate reader (Versamax, Molecular Devices, Sunnyvale, CA). The half maximal inhibitory 
concentration $\left(\mathrm{IC}_{50}\right)$ of the compound was determined from a concentration-response curve using Sigma Plot software version 8 (Systat Software Inc., Point Richmond, CA, USA).

\subsubsection{Cell lysate preparation}

Glass beads (425-600 $\mu$ m diameter, Sigma Aldrich) were soaked in $1 \mathrm{M} \mathrm{HCl}$ for 16 hours then thoroughly rinsed in $\mathrm{dH}_{2} \mathrm{O}$, followed by drying for 16 hours. The prepared glass beads were chilled in ice before use.

Fifteen $\mathrm{mL}$ of yeast culture was centrifuged at $20000 \mathrm{rpm}$ (Eppendorf centrifuge 5810) and the media was decanted off. The cells were resuspended in $2 \mathrm{~mL}$ of lysis buffer $(50 \mathrm{mM}$ Tris. $\mathrm{HCl}, \mathrm{pH} 7.6,1 \mathrm{mM}$ EDTA and 10 $\mu \mathrm{L}$ protease inhibitor mixture). To the buffered culture was added $6 \mathrm{~g}$ of the prepared glass beads, this was then vortexed at full speed 5 times for 8 $\mathrm{min}$, between each cycle the cells were kept on ice for $2 \mathrm{~min}$. After the 5 cycles, the glass beads were removed by pipetting out the media and the cell debris was removed by ultra-centrifugation at $4{ }^{\circ} \mathrm{C}$ for 30 min at 45000 rpm (Optima ${ }^{T M L}$-100 XP Ultracentrifuge).

\subsubsection{Bradford protein quantification}

Ten $\mu$ of the cell lysate was diluted 10-fold with $50 \mathrm{mM}$ Tris. $\mathrm{HCl} \mathrm{pH} 7.5$ buffer, of which 1-5 $\mu$ aliquots were taken and made up to $10 \mu$ with the appropriate volume of $50 \mathrm{mM}$ Tris. $\mathrm{HCl} \mathrm{pH} 7.5$ buffer in a 96 well plate. Two hundred $\mu \mathrm{l}$ of Bradford reagent was added. A BSA standard with a defined concentration (200-1500 $\mathrm{mg} / \mathrm{ml}$ ) was set up on the same 96 well plate. The absorbance was read by (plate reader) at $340 \mathrm{~nm}$ and the results were graphed with the linear regression of the standards. 


\subsubsection{Affinity matrix preparation}

To a solution of $1.26 \mathrm{mg}$ of $\mathrm{N}$-propargyl-3-aminopropanol in $3 \mathrm{~mL}$ of THF and $4 \mathrm{~mL}$ of $\mathrm{dH}_{2} \mathrm{O}$ was added $600 \mathrm{mg}$ of epoxy-activated sepharose matrix (Sigma-Aldrich). The mixture was shaken at $33^{\circ} \mathrm{C}$ for 16 hours before the mixture was centrifuged down at $2000 \mathrm{rpm}$ for $1 \mathrm{~min}$. The solvent was decanted off, and $6 \mathrm{~mL}$ ethanol was added. The ethanol mixture was vortexed for $1 \mathrm{~min}$ then centrifuged at $2000 \mathrm{rpm}$ for $1 \mathrm{~min}$, the solvent was decanted and replaced with $6 \mathrm{~mL}$ of diethyl ether. The solution was vortexed for $1 \mathrm{~min}$ then centrifuged in an enclosed falcon tube at 2000 rpm for $1 \mathrm{~min}$ before the solvent being decanted, this last step was repeated. The resulting matrix was further dried in a vacuum.

\subsubsection{Affinity matrix derivatisation}

To a solution of $20 \mathrm{mg}$ of 6-[2-(4-azidophenyl)ethyl] azulene in $1 \mathrm{~mL}$ of THF and $1 \mathrm{~mL}$ of cell lysate (S. cerevisiae) was added $5 \mathrm{mg}$ of ascorbic acid and sodium hydroxide to neutralise the solution, then $0.1 \mathrm{~mL}$ sat. aqueous copper sulphate was added. The solution was stirred for $5 \mathrm{~min}$ before 300 $\mathrm{mg}$ of the alkyne-substituted sepharose matrix was added. A second sample was made as above but with the unmodifed epoxy-activated sepharose matrix. The mixtures were shaken at $33^{\circ} \mathrm{C}$ overnight. Both solutions were then centrifuged at $2000 \mathrm{rpm}$ for $2 \mathrm{~min}$ and the solvents were then decanted off. The following wash steps were then carried out on both samples: $2 \times 6 \mathrm{~mL}$ water, $2 \times 6 \mathrm{~mL}$ ethanol, $2 \times 6 \mathrm{~mL}$ diethyl ether. For each wash, the sample was centrifuged in an enclosed falcon tube at 2 $000 \mathrm{rpm}$ for $1 \mathrm{~min}$ then solvent decanted. A solution of $2 \mathrm{M}$ Ammonia was then used to dissolve any remaining copper, this was followed by the removal of the ammonia by centrifugation at $2000 \mathrm{rpm}$ the matrix was then washed multiple times with $\mathrm{dH}_{2} \mathrm{O}$. 


\subsubsection{Huisgen Cyclisation of 24 to the alkyne-substituted sepharose matrix}

To a prepared yeast lysate (section 3.3.6), compound $\mathbf{2 4}$ was added and shaken at $33^{\circ} \mathrm{C}$ for $6 \mathrm{~h}$ before the alkyne-substituted sepharose matrix was added, along with $0.1 \mathrm{~mL}$ saturated copper sulphate, and $5 \mathrm{mg}$ of ascorbic acid neutralised by aqueous sodium hydroxide. The mixture was shaken at $33{ }^{\circ} \mathrm{C}$ for $12 \mathrm{~h}$. Centrifugation at $4000 \mathrm{rpm}$ for $5 \mathrm{~min}$ and decanting off the supernatant provided the derivatised matrix, which was then washed with $1 \mathrm{M}$ Tris. $\mathrm{HCl}$ buffer $\mathrm{pH}$ 7.5, again centrifuged at 4000 rpm for $5 \mathrm{~min}$ and the buffer decanted off. The above was repeated with the alkyne-substituted sepharose matrix without the copper species (Discussion 3.5.4) as a control.

\subsubsection{Peptide preparation}

One hundred $\mu \mathrm{L}$ of $100 \mathrm{mM}$ Tris. $\mathrm{HCl} \mathrm{pH} 8.8$ with $0.5 \mathrm{M}$ urea was added to the lysate-matrix prepared in section 3.3.10. This was then vortexed. To the suspension, $1 \mu \mathrm{L}$ of NuPage reducing agent (Life Technologies) was added, this was then incubated at $55^{\circ} \mathrm{C}$ for $35 \mathrm{~min}$. After this time, the sample was cooled to room temperature. One $\mu \mathrm{L}$ of freshly made $0.5 \mathrm{M}$ iodoacetamide (0.023 $\mathrm{g}$ in $250 \mu \mathrm{L}$ MilliQ water) was added and left for 30 min in the dark. To the sample, $0.5 \mu \mathrm{L}$ of $0.5 \mathrm{M}$ calcium chloride and $1 \mu \mathrm{gg}$ of trypsin in $20 \mu \mathrm{L}$ of $100 \mathrm{mM}$ Tris $\mathrm{pH} 8.8$ with $0.5 \mathrm{M}$ urea was added and incubated over night at $35^{\circ} \mathrm{C}$ with rotation.

The matrix was removed by centrifugation at $2000 \mathrm{rpm}$ for $3 \mathrm{~min}$, the buffer was evaporated by centrivap concentrator. The tryptic peptides were re-suspended in $20 \mu \mathrm{L}$ of $0.1 \%$ TFA. 


\subsubsection{ZipTip purification}

A PerfectPure C-18 Tip (Eppendorf) was attached to a pipette and washed before peptides were attached. The wash consisted of $3 \times 10 \mu \mathrm{L}$ acetonitrile, $3 \times 10 \mu \mathrm{L} 50: 50$ acetonitrile/ 0.1\% TFA and then 5x $10 \mu \mathrm{L} 0.1 \%$ aqueous TFA. Following the wash, the samples of peptides in $20 \mu \mathrm{L} 0.1 \%$ aqueous TFA prepared in section 3.3.11 were aspirated and expelled 20x to attach the peptides to the tip. The tips were then washed with $3 \times 10 \mu \mathrm{L}$ with $0.1 \%$ aqueous TFA. The peptides were then eluted off the tip with 1.5 $\mu \mathrm{L}$ acetonitrile/ $0.1 \%$ aqueous TFA (80:20). The sample was allowed to dry in positive air flow. The above was repeated with the alkyne-substituted sepharose control sample.

\subsubsection{Protein identification}

Proteins were identified by peptide mass fingerprinting. Proteins were cleaved from the alkyne-substituted matrix as described in 3.7.11 and 3.7.12. The resulting peptide fragments were then subjected to MALDI analysis on an AB SCIEX TOF-TOFTM 5800 spectrometer. The sequences acquired from this process were then searched against the yeast protein database using the MASCOT algorithm.

\subsubsection{Preparation of protein spots for MALDI analysis}

The dried peptides from section 3.3.12 were resuspended in $1.5 \mu \mathrm{L}$ of CHCA (alpha-Cyano-4-hydroxycinnamic acid) Matrix $(8 \mathrm{mg} / \mathrm{mL} \mathrm{CHCA}, 1 \%$ aqueous TFA and 50\% acetonitrile 1:1). Resuspened samples were transferred onto a MALDI plate and left to dry.

\subsubsection{MALDI-TOF MS/MS analysis}

MALDI TOF-TOF MS/MS analysis of samples was carried out using an $A B$ SCIEX TOF-TOFTM 5800 spectrometer (Applied Biosystems, Foster City, CA) 
equipped with a diode pulse laser $(355 \mathrm{~nm}, 1 \mathrm{kHz})$. The spectrometer was controlled by TOF-TOFTM Series ExplorerTM software.

\subsubsection{Acquisition of spectra for MS}

Spectra for MS analysis were acquired in positive reflector mode with CID off. Peptide fragments were collected in the mass range 700- $4000 \mathrm{Da}$. The laser intensity was fixed at 5500 with a pulse rate of $400 \mathrm{~Hz}$. The laser was fired in a uniform random pattern. A total of 400 laser shots were collected per spectrum.

\subsubsection{Calibration of spectra for MS}

MS spectra were internally calibrated using CalMix2 (Applied Biosystems) monoisotpic peaks of des-Argl-Brodykinin (904.4680), angiotensin 1 (m/z 1296.6770), adrenocorticotropic hormone (ACTH) clip 1-17 (m/z 2093.0870), ACTH clip 18-39 (m/z 2465.1990) and ACTH clip 7-38 (3657.9294). Peak matching criteria for calibration included signal to noise ratio greater than or equal to five, mass tolerance of $\pm 0.1 \mathrm{~m} / \mathrm{z}$, a minimum of three matched peaks, and maximum outlier error of $1 \mathrm{~m} / \mathrm{z}$. A list of reference masses is shown in appendix 8.0.

\subsubsection{Precursorion selection for MS/MS}

Selection criteria for precursors to undergo MS/MS analysis included a signal to noise ratio greater than or equal to 20 , mass within the range 800 $4000 \mathrm{Da}$, and exclusion of precursor ions within a resolution of 200 of the selected precursor ion. Known adduct, calibration and common contaminant peaks, such as trypsin were excluded. A full list of exclusion masses is shown in appendix 8.0. A maximum of 60 precursor ions were selected per spot. MS/MS data were acquired from strongest precursor ion first.

\subsubsection{Acquisition of spectra for MS/MS}

Spectra for MS/MS analysis were acquired in $1 \mathrm{kV}$ positive reflector mode, with CID and metastable suppressor on. The laser intensity was fixed at 5800 with a pulse rate of $1000 \mathrm{~Hz}$. The laser was fired in a random uniform 
pattern. Acquisition of spectra was stopped after four sub-spectra were collected. A total of 1000 laser shots were collected per full spectrum.

\subsubsection{Calibration of spectra for MS/MS}

The monoisotopic angiotensin 1 peak (1296.4680) was selected as a precursor ion for calibration. MS/MS spectra were then calibrated using known fragment ion masses for this precursor ion (appendix 8.0). Peak matching criteria for calibration included a signal to noise ratio greater than or equal to 10 , mass tolerance $\pm 0.03 \mathrm{~m} / \mathrm{z}$, a minimum of five matched peaks, and maximum outlier error of 100 ppm

\subsubsection{Comparison of peptide sequences to S. cerevisiae data base} Peptide fingerprints and MS/MS sequences were imported into Protein PilotTM 3.0 software. The MASCOT algorithm was used to search the generated peaks list against the $\mathrm{NCBI}$ non-redundant data base (2008/09/02, 21331 sequences) for S. cerevisiae (905409 sequences) for proteins obtained from $S$. cerevisiae samples.

\subsubsection{Validation of benzose breakdown in agar}

Hot SC-agar $\left(50^{\circ} \mathrm{C}\right)$ containing $60 \mu \mathrm{M}$ benzose was poured in to five Singer plates. At time intervals of four, 10, 14 and $18 \mathrm{~h}$ after pouring, the plates were pinned by the use of Singer RoToR HDA with plate 10 of the $\Delta p d r 1 \Delta p d r 3 \Delta x x x$ library. After $24 \mathrm{~h}$ of incubation at $33^{\circ} \mathrm{C}$ each plate was photographed and the growth of each spot was determined by colony HT analysis. 


\subsubsection{Genomic screen}

The genomic screen used in these studies was modified by Namal Coorey within the Chemical Genetic Group, School of Biological Sciences, Victoria University of Wellington. The screen was adapted from Tong \& Boone 2006 to create a library containing the background with null mutations in the PDR1 and PDR3 transcription factors. The library was maintained as haploid MATa mutants in 1536 colonies per plate format on 14 plates. Each plate contained 384 strains in quadruplicate with a his3 $3::$ kanR control stain border comprising 144 colonies along the side of the plate. Since the genomic screen identifies sensitive and resistant strains by colony size, the his3s::kanR border acts as a buffer to prevent strains from being susceptible to edge effects such as, more access to media and less competition. The his $3 \Delta:: k a n R$ was used as the border because it does not show any genetic interaction with any query mutations since histidine prototrophy is achieved via canla:STE2pr-sp-HIS5 in the recombinant MATa strains.

The $\Delta p d r l \Delta p d r 3 \Delta x x x$ gene deletion library was copied on to SC agar plates in a 1536 arrangement which consisted of four replicates arranged in a box formation, as well as a $\Delta$ his3 border that consisted of the two outer rows and columns of the plates. Fifty six $40 \mathrm{~mL} \mathrm{SC}$ agar plates were poured after autoclaving, with 14 having no drug and $800 \mu \mathrm{L}$ DMSO as the control and the remaining 42 having $60 \mu \mathrm{M}$ benzose ( $48 \mu \mathrm{L}$ of $50 \mathrm{mM}$ stock in DMSO) and $752 \mu \mathrm{L}$ DMSO, both having a DMSO concentration of $2 \%$. The DMSO benzose solution was not added until the agar had cooled to $50{ }^{\circ} \mathrm{C}$. Plating of the 1536 array yeast on to the drug and control plates was done using the Singer RoTor HDA. The treated and control plates were incubated at $30^{\circ} \mathrm{C}$. At 18,24 and $36 \mathrm{~h}$, photographs were taken of each plate, these were then subjected to Colony HT analysis to determine the size of each yeast colony.

Resistant strains were defined as those where the residual growth of benzose-treated strains was found to be above two standard deviations 
from the total average residual growth in at least one of the technical replicates in 2 of 3 biological replicates. Residual growth is defined as the average of the quadruplet of benzose treated in each strain divided by the average of the corresponding quadruplet of DMSO control. If one of the four colonies of the quadruplet was outside of two standard deviation points from the average colony was rejected.

Sensitive strains were defined as those where the residual growth of benzose treated strains was found to be below two standard deviations from the total residual growth average in at least one of the technical replicates in 2 of 3 biological replicates.

\subsubsection{Validation of the genomic screen}

Each yeast strain that was shown to be resistant in the genomic screen was treated to 30, 50 and $70 \mu \mathrm{M}$ benzose, following the methods described for $\mathrm{IC}_{50}$ analysis liquid phase assay (section 3.3.4).

For each strain, an aliquot of $98 \mu \mathrm{L}$ of $5 \times 10^{6}$ cells/ $\mathrm{mL}$ was removed from the mid log culture and placed into 96 well round bottom plate. To each aliquoted yeast strain was added $2 \mu \mathrm{L}$ the appropriate concentration of benzose in DMSO. The samples were sealed by a plastic film and left in an incubator for 36 hours. After this time the samples were shaken before being read by the plate reader $\left(O_{590}\right)$. To be validated as a resistant strain, the strain had to have a residual growth greater than 0.4 at $50 \mu \mathrm{M}$ of benzose, 10 standard deviations above $\Delta$ his3 residual growth average (0.362 \pm 0.004$)$.

This method was also used to validate the sensitive strains but with lower benzose concentrations of 10,30 and $50 \mu \mathrm{M}$. To be validated, strains had to have residual growth below 0.555 at $30 \mu \mathrm{M}$ of benzose, two standard deviations below $\Delta$ his 3 residual growth average $(0.685 \pm 0.065)$. 


\subsubsection{Unfolded protein response element (UPRE) assay}

The UPRE assay was carried out by James. H Matthews (within the Chemical Genetic Group, School of Biological Sciences, Victoria University of Wellington) with the 4xUPRE-GFP (Unfolded Protein Response ElementGreen Fluorescent Protein) strain. A single colony of YCG266 was inoculated into $3 \mathrm{~mL} \mathrm{SC}$ and grown overnight at $30^{\circ} \mathrm{C}$ on a rotating drum. Cell titre was diluted to $5 \times 10^{6}$ cells $/ \mathrm{mL}$ with SC and resuspended. Fifty $\mu \mathrm{L}$ aliquots of this cell suspension were dispensed into a PerkinElmer 384-well CellCarrier confocal microscopy plate, with a concentration range of 200 , $100,50,25,12.5,6.75,3.85 \mu \mathrm{M}$ dilutions of benzose and DTT at $0.025 \mathrm{mM}$. $\mathrm{ddH}_{2} \mathrm{O}$ and $2 \%$ DMSO were aliquoted into separate wells as controls. The treated cultures were incubated at $30^{\circ} \mathrm{C}$ for $4 \mathrm{~h}$, before being read with an Opera High Content Screening System confocal microscope (PerkinElmer). Excitation and emission wavelengths were 488 and $520 \mathrm{~nm}$ (GFP), and 561 and $600 \mathrm{~nm}$ (RFP) respectively. Data from this assay was analysed using Acapella software (PerkinElmer), with Ln(GFP/mCherry) being calculated to determine activation of the unfolded protein response. 


\subsection{Results}

The aim of this study was to determine the potential target of a lead compound and to investigate which cellular pathways it affects. To identify the lead compound, a structure activity relationship (SAR) assay was completed. The SAR assay was also designed to help determine the likely binding mechanism that is occurring when interacting with the protein of interest (assuming covalent interactions). Identification of proteins that interact directly with the lead compound was attempted using affinity chromatography and mass spectrometry. A yeast-based genetic deletion approach was undertaken using a drug sensitised $\Delta \mathrm{pdrl} \Delta \mathrm{pdr} \Delta \mathrm{xxx}$ genetic mutant array.

\subsubsection{Benzose is active in $\Delta p d r 1 \Delta p d r 3$ dual knockout $S$. cerevisiae}

The first synthesised compound (benzose) was subjected to a general inhibitory assays against $S$. cerevisiae BY4741 wild type and $\Delta p d r 1 \Delta p d r 3$ dual knock out strains and two stains of human cell lines, HL-60 (human promyelocytic leukaemia) and 1A9 (human ovarian cancer) cells. Each assay was completed in triplicate. The BY4741 wild type yeast was not sensitive towards benzose at any of the concentrations tested, with a growth rate within $10 \%$ of the non-treated control at each concentration. The $\Delta p d r l \Delta p d r 3$ strain had an $I_{50}$ of $44 \mu M$; maximal cell death was observed at $100 \mu \mathrm{M}$ (figure 3.3). At the higher end of the concentration range the cell survival apparently increased. This was due to benzose precipitating in the aqueous solution at these higher concentrations. When the DMSO carrier was increased from $2 \%$ to $4 \%$, the increase in survival was no longer observed. 


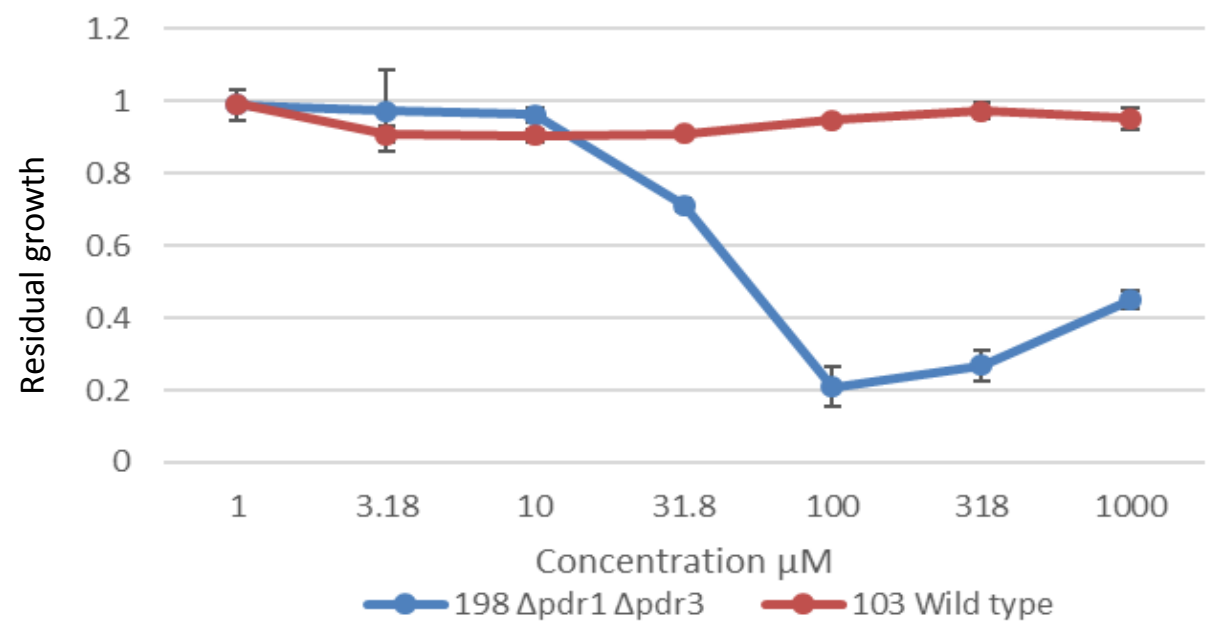

Figure 3.3. S. cerevisiae $\Delta p d r 1 \Delta p d r 3$ dual knock out and BY4741 treated with benzose. Benzose showed activity against $\Delta p d r 1 \Delta p d r 3$ with an $\mathrm{IC}_{50}$ of $44 \mu \mathrm{M}$, however, no activity was found against BY4741 cells. This strongly suggests that benzose is a substrate for the membrane ATP-binding cassette $(A B C)$ transporter, which is regulated by the PDR1 and PDR3 transcription factors. Results were measured at $\mathrm{OD}_{590}$, in triplicates. Values shown are the average of triplicate experiments, with the error bars representing the standard deviation. 


\subsubsection{Serial dilution assay}

The serial spot dilution assay was undertaken as described in section 3.3.5, to determine whether benzose acts as a cytotoxic or cytostatic compound. The two strains of yeast were grown in liquid culture at the concentrations shown in figure 3.4; cells were serially diluted then transferred onto drug-free agar. It was found that at high concentrations (314 $\mu \mathrm{M}$ above) benzose is cytotoxic in the initial treatment, leading to no growth on the drug-free agar. At lower concentrations $(314 \mu \mathrm{M}$ and below) benzose acts as cytostatic compound, and growth resumed unimpeded following transfer. Figure 3.4 confirms that BY4741 is not effected by benzose. However, $\Delta p d r l \Delta p d r 3$ at high concentrations is showing no growth after the $2^{\text {nd }}$ serial dilution at $314 \mu \mathrm{M}$ and the $3^{\text {rd }}$ dilution at $101 \mu \mathrm{M}$. At lower concentrations the $\Delta p d r l \Delta p d r 3$ are able to

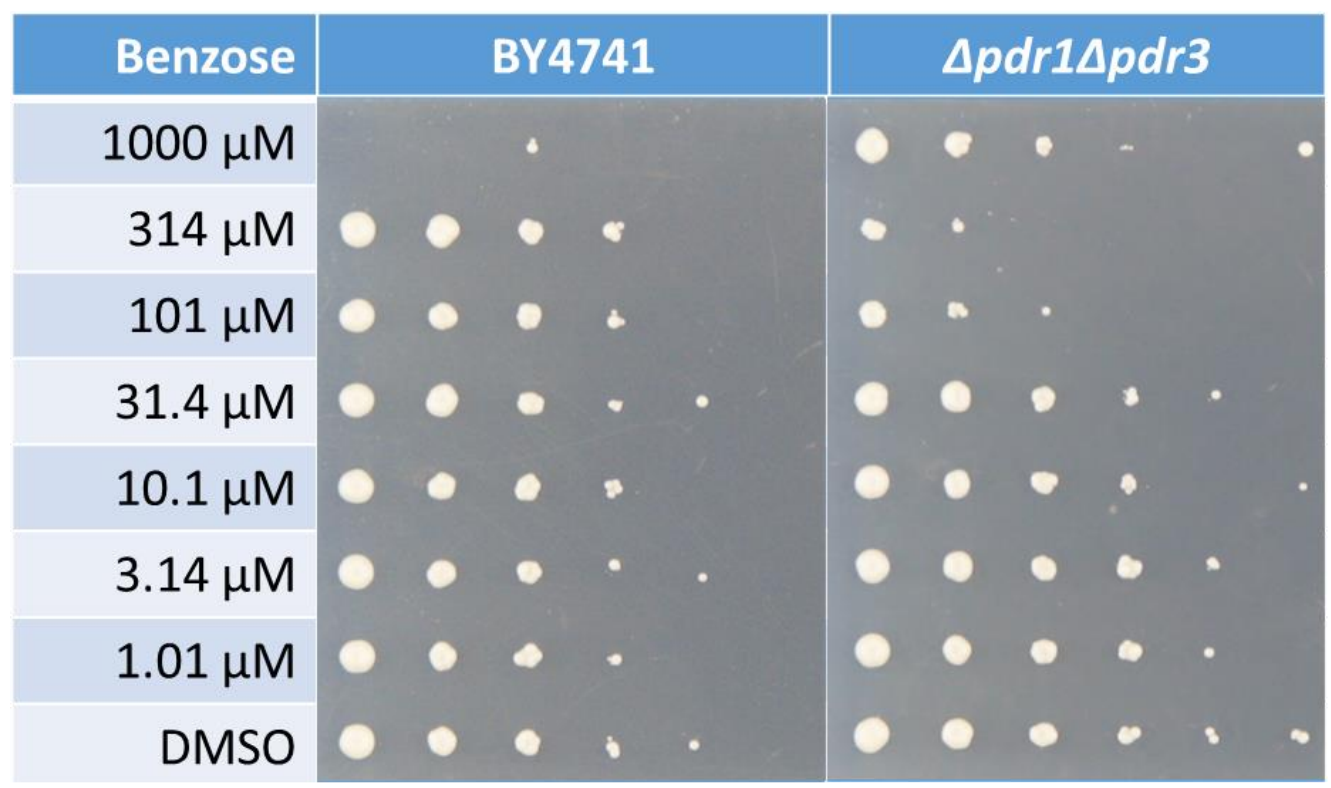

Figure 3.4. Benzose is cytostatic and cytotoxic. Shown here, a double serial dilution, the vertical dilution is a decreasing concentration of benzose, and the horizontal is a 1:4 dilution of cells. As the concentration is increased, cellular growth is decreased showing both cytostatic and cytotoxic characteristics. The serial dilution assay was repeated in triplicate, shown here is representative of the three replicates. Note, at high concentrations benzose percipates out of solution resulting in increased cell growth, BY4741 at $1000 \mu \mathrm{M}$ its due to plating error. 
fully recover at all serial dilutions. It has to be noted that $1000 \mu \mathrm{M} \mathrm{a}$ pipetting error occurred due to a defective channel (hence no growth for the BY4741 strain) and benzose percipates out of solution resulting in decreased toxicity.

\subsubsection{Identification of the lead compound through SAR analysis}

The structure activity relationship study was undertaken as described in section 3.3.4. The study was designed to identify the most active compound in S. cerevisiae, the study was also designed to identify the potential mechanism by which the compounds act on their biological target. Structural variations were limited to the groups on oxygen at C-3, C-6 and varying the substituent on the cyclopropanes. As discussed in section 1.4.2, should these cyclopropanated glycals bind covalently to their target protein, they are likely to do so through one of three possible mechanisms.

The compound library consisted of 27 glycals (table 3.1), of which 20 contain a cyclopropane; 12 of these are chlorine containing and six contain bromides; the remaining two cyclopropanes are unsubstituted. All glycals were tested under the same conditions as benzose (section 3.3.4) against two strains of yeast, the BY4741 wild type and $\Delta p d r 1 \Delta p d r 3$. Only four compounds $(\mathbf{7}, \mathbf{1 1}, \mathbf{1 5}, 25$ and 27) were sufficiently active in $\Delta p d r 1 \Delta p d r 3$ to permit determination of an $I_{50}$. Others were inactive or only partially active below their solubility limit in $2 \%$ DMSO; only compound 27 showed activity in the BY 4741 wild type yeast.

The most active compound was then tested against the human cell lines HL-60 and 1A9, benzose was inactive in both human cell lines tested. 
<smiles>[R6]C1C=COC([R])[C@@H]1[R20]</smiles>

\section{Compound} number

1
3
4
5
6
7
8
9

10

11

12

13

14

15

16

17

18
$R^{1} \quad R^{2}$

$\mathrm{CH}_{2} \mathrm{OAC} \quad \mathrm{AC}$

$\mathrm{CH}_{2} \mathrm{OTr} \quad \mathrm{H}$

$\mathrm{CH}_{2} \mathrm{OTr} \quad \mathrm{Bn}$

$\mathrm{CH}_{2} \mathrm{OTr} \quad \mathrm{Bn}$

$\mathrm{CH}_{2} \mathrm{OTr} \quad \mathrm{Bn}$

$\mathrm{CH}_{2} \mathrm{OH} \quad \mathrm{Bn}$

$\mathrm{CH}_{2} \mathrm{OCHO} \quad \mathrm{Bn}$

$\mathrm{CH}_{2} \mathrm{OH} \quad \mathrm{Bn}$

$\mathrm{CH}_{2} \mathrm{OCHO} \quad \mathrm{Bn}$

$\mathrm{COOH} \quad \mathrm{Bn}$

$\mathrm{CH}_{2} \mathrm{OTr} \quad \mathrm{Bn}$

$\mathrm{CH}_{2} \mathrm{OTr} \quad \mathrm{Bn}$

$\mathrm{CH}_{2} \mathrm{OH} \quad \mathrm{Bn}$

$\mathrm{CH}_{2} \mathrm{OH} \quad \mathrm{Bn}$

$\mathrm{CH}_{2} \mathrm{OTr} \quad \mathrm{Bn}$

$\mathrm{CH}_{2} \mathrm{OH}$
$\mathrm{CH}_{2} \mathrm{OH} \quad \mathrm{Bn}$

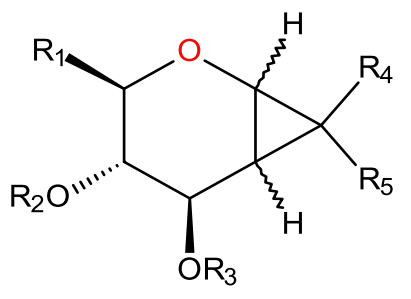

$\Delta p d r 1$

$\mathrm{R}^{3}$

$\begin{array}{lll}\mathrm{R}^{4} \quad \mathrm{R}^{5} & \begin{array}{l}\text { Cyclo- } \\ \text { propane }\end{array}\end{array}$

BY4741 $\Delta p d r 3$

$\mu M \quad \mu M$

Ac

H

$\mathrm{Bn}$

$\mathrm{Bn}$

$\mathrm{Cl} \mathrm{Cl}$ Down

$\mathrm{Bn}$

Cl Cl Up

$\mathrm{Bn}$

$\mathrm{Cl} \mathrm{Cl}$ Down

$40 \pm 1.2$

$\mathrm{Bn}$

$\mathrm{Cl} \mathrm{Cl}$ Down

$\mathrm{Bn}$

$\mathrm{Cl} \mathrm{Cl}$ Up

$\mathrm{Bn}$

$\begin{array}{lll}\mathrm{Cl} & \mathrm{Cl} & \mathrm{Up}\end{array}$

$\mathrm{Bn}$

$\mathrm{Cl} \mathrm{H}$ Down

$300 \pm 15$

$\mathrm{Bn}$

$\mathrm{Cl} \mathrm{Cl}$ Down

$\mathrm{Bn}$

$\mathrm{Br} \mathrm{Br}$ Down

$\mathrm{Bn}$

$\mathrm{Br} \quad \mathrm{Br} \quad \mathrm{Up}$

$\mathrm{Bn}$

$\mathrm{Br} \mathrm{Br}$ Down

$150 \pm 19$ 


$\begin{array}{lllllllll}24 & \mathrm{CH}_{2} \mathrm{OH} & \mathrm{p}-\mathrm{N}_{3} \mathrm{Bn} & \mathrm{p}-\mathrm{N}_{3} \mathrm{Bn} & \mathrm{H} & \mathrm{H} & \text { Down } & - & - \\ 25 & \mathrm{CH}_{2} \mathrm{OTr} & \mathrm{Bn} & \mathrm{H} & \mathrm{Cl} \mathrm{Cl} \text { Down } & - & 200 \pm 22 \\ 26 & \mathrm{CH}_{2} \mathrm{OH} & \mathrm{H} & \mathrm{Bn} & \mathrm{Cl} \mathrm{Cl} \text { Down } & - & - \\ 27 & \mathrm{CH}_{2} \mathrm{OH} & \mathrm{Bn} & \mathrm{H} & \mathrm{Cl} \mathrm{Cl} \text { Down } & 500 \pm 9 & 400 \pm 24 \\ 28 & \mathrm{CH}_{2} \mathrm{OBn} & \mathrm{Bn} & \mathrm{Bn} & - & - & - & - & - \\ 30 & \mathrm{CH}_{2} \mathrm{OBn} & \mathrm{Bn} & \mathrm{Bn} & \mathrm{Cl} \mathrm{Cl} \text { Down } & - & - \\ 30 & \mathrm{CH}_{2} \mathrm{OBn} & \mathrm{Bn} & \mathrm{Bn} & \mathrm{Cl} \mathrm{Cl} \mathrm{Up} & - & - \\ 31 & \mathrm{CH}_{2} \mathrm{OH} & \mathrm{H} & \mathrm{H} & \mathrm{Cl} \mathrm{Cl} \text { Down } & - & - \\ 32 & \mathrm{CH}_{2} \mathrm{OBn} & \mathrm{Bn} & \mathrm{Bn} & \mathrm{Br} \mathrm{Br} \text { Down } & - & - \\ 33 & \mathrm{CH}_{2} \mathrm{OBn} & \mathrm{Bn} & \mathrm{Bn} & \mathrm{Br} \mathrm{Br} \text { Up } & - & -\end{array}$

Table 3.1. $I C_{50}$ analysis of the library synthesised in chapter 2 against yeast strains BY4741 and $\Delta p d r 1 \Delta p d r 3$. All compounds were tested. Those with no measurable activity are shown with a dash (-). Five compounds were identified as active against $\Delta p d r l \Delta p d r 3$, with one showing activity against BY4741. Each compound was measured against the two strains of $S$. cerevisiae at $1,0.314,0.100,0.031,0.010$, 0.003 and $0.001 \mathrm{mM}$ in three technical and two biological replicates. 


\subsubsection{Matrix derivatisation}

The matrix derivatisation was undertaken as described in section 3.3.9 of the methods. The study was carried out to synthesise a matrix that would have an alkyne that would act as an attachment point to $\mathbf{2 4}$, which contains an azide moiety which is able to undergo a Huisgen cyclization reaction within a cell lysate. This was carried out in two steps, 1) The attachment of the alkyne-substituted amine to the epoxide and 2) subsequent Huisgen cyclization. An experiment was carried out to confirm that the resin can capture the azide derivative, as indicated by a colour change since traditional identification techniques (NMR, IR and MS) are not suitable for resin-supported chemistry. An azulene-azide derivative (6[2-(4-azidophenyl)ethyl] azulene) that is coloured bright blue and contains a p-azidobenzyl group was chosen as a substrate to show that cyclization is possible. The bright blue colour could not be removed from the matrix when washed with multiple solvents (water, ethanol and ether), showing the cyclization worked and the 6-[2-(4-azidophenyl)ethyl]azulene was attached via the copper-activated Huisgen Cyclization.

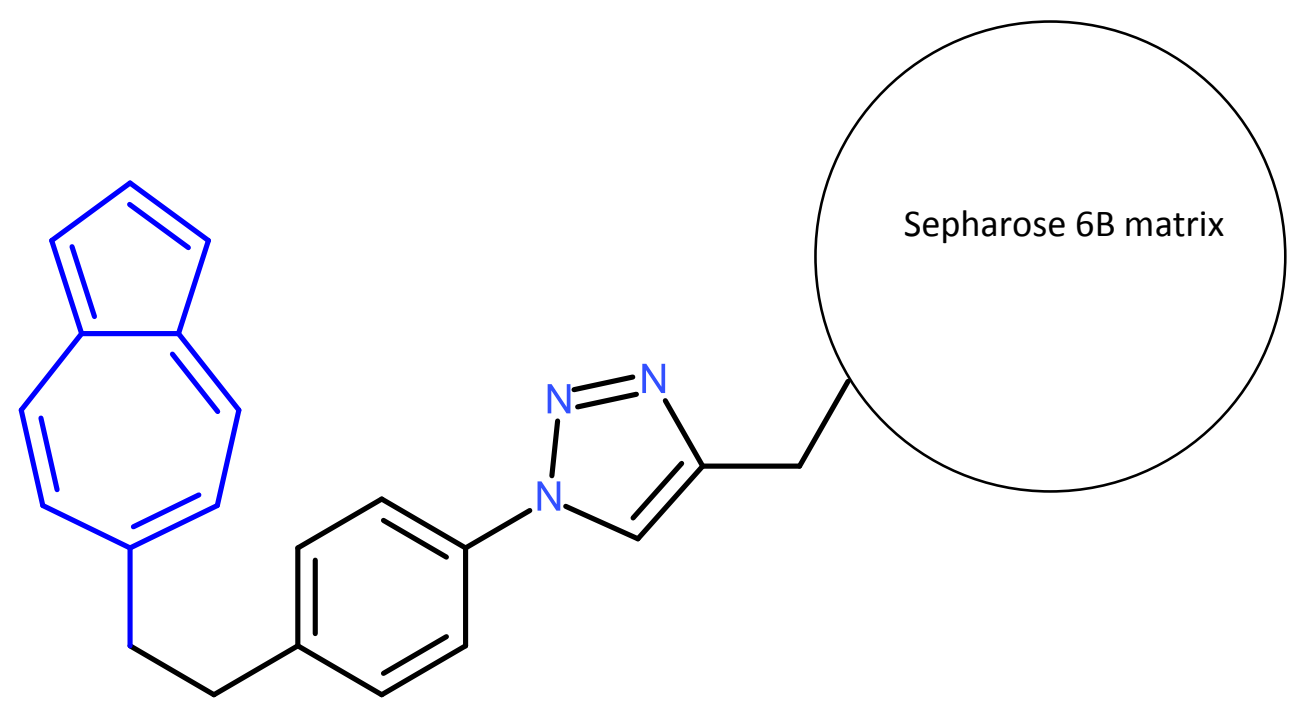

Figure 3.5. Proposed structure of the azulene-azide derivative undergoing a Huisgen Cyclisation, resulting in "staining" of the matrix bright blue. 


\subsubsection{Chemical proteomic analysis}

A chemical proteomic analysis study was undertaken as described in section 3.3.13. The study was employed to determine the potential biological target(s) of benzose.

An MS/MS analysis was used to determine the identity the peptides that were digested off the lysate treated 24-matrix. The control resin (alkynesubstituted matrix without 24 attached) was shown to have interacted with three proteins with a Z-score greater than 56 which was determined by Protein Pilot ${ }^{T M} 3.0$ to be the cut off for statistically relevant results. All proteins found were part of the glyceraldehyde-3-phosphate dehydrogenase family, presumably retained due to residual epoxide groups that had not fully reacted with 3-aminopropan-1-ol (McCaul \& Byers, 1976). The study with the $\mathbf{2 4}$-matrix presented four proteins with three matching those isolated by the control resin; the glyceraldehyde-3phosphate dehydrogenase family. The remaining protein was with a Zscore of 73, Tef2p, TEFl encodes the Translational elongation factor EF-1 alpha, however this was also then identified in the control resin upon validations. Subsequent bioactivity analysis of $\mathbf{2 4}$ indicates that the compound is inactive, and this is likely to explain the inability of the 24derivatised matrix to retain proteins (see section 3.4.3). Currently no biological targets have been identified. 


\subsubsection{Benzose breaks done in agar}

The $\mathrm{IC}_{50}$ of benzose in solid agar had to be determined before undertaking the chemical genomic screen. The initial experiment unexpectedly showed no activity of benzose against any strain of plate 10 of the $\Delta p d r l \Delta p d r 3 \Delta x x x$ library, up to $100 \mu M$. Subsequently a second experiment was carried out at concentrations up to $200 \mu \mathrm{M}$, in this case an $\mathrm{IC}_{50}$ was recorded at $70 \mu \mathrm{M}$, which was inconsistent to the previous study. It was proposed that the benzose might be breaking down in agar. To test this, an experiment was carried out where plates were left for 4, 10, 14 and 18 hours from pouring. Plates older than 14 hours showed a marked decrease in activity of benzose; the change in $\mathrm{IC}_{50}$ with time is shown in figure 3.6. On the basis of these results, 4 hours after the plates were poured was determined to be the best for the subsequent chemical genomic screen, permitting the agar to cool and set, but retain activity. Temperature was also determined to be a factor in the breaking down of benzose, it was decided to add benzose to the agar directly before each plate was poured to limit the contact with heated agar.

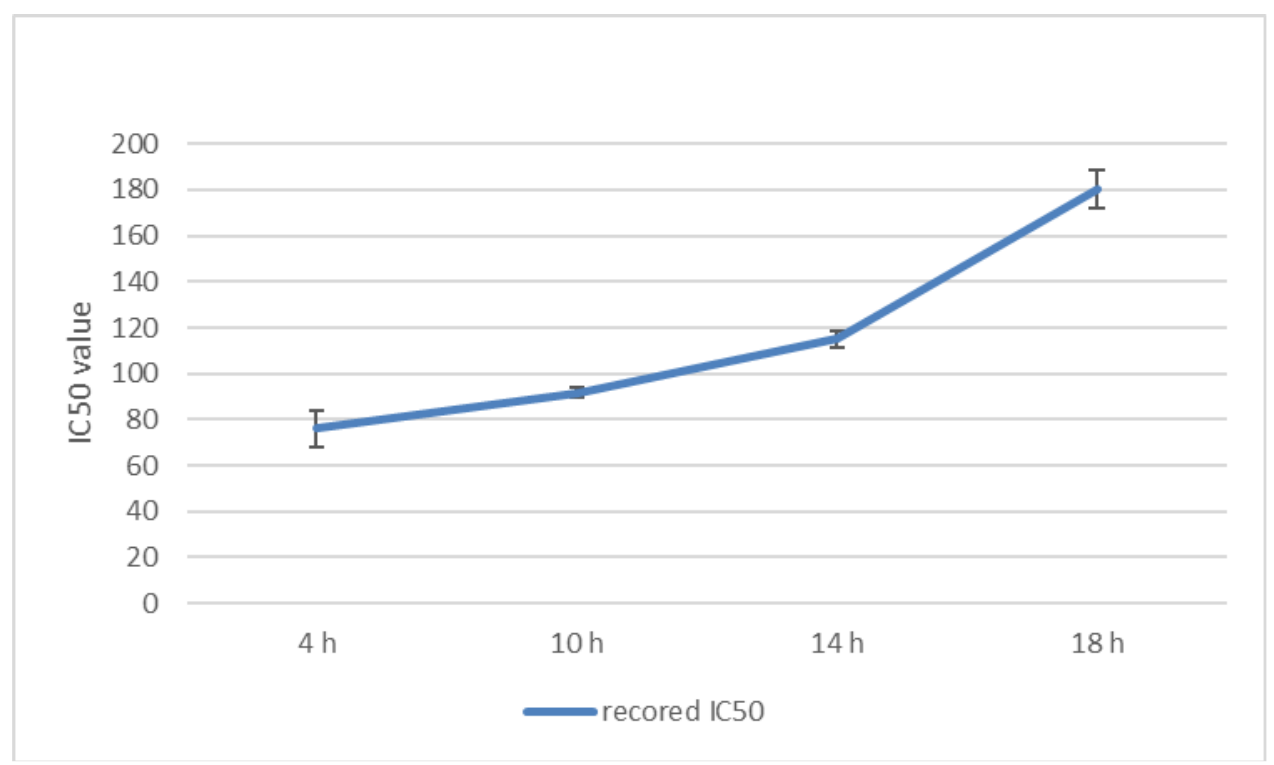

Figure 3.6. Breakdown of benzose in agar. It was found that benzose breaks down to unknown products over time, decreasing the activity against $\Delta \mathrm{pdr} 1 \Delta \mathrm{pdr} 3$. The data points represent average concentration of benzose required to reach the $\mathrm{IC}_{50}$ at each time point. The error bars equate to the standard deviation between the three replicates. 


\subsubsection{Chemical genomic Assay}

The PDR 1 and PDR3 genes encode transcription factors for elements of the pleiotropic drug resistance network including the major efflux pump pdr5. The library of $\Delta p d r l \Delta p d r 3 \Delta x x x$ modified yeast strains is thus sensitised toward drug-like compounds, while also harbouring a different gene deletion in each strain of the library. This was tested against benzose to identify strains that had elevated sensitivity or resistance to the compound. To be classified as resistant, the yeast strain had to show residual growth above 0.40 at $50 \mu \mathrm{M}, 10$ standard deviations above $\Delta p d r 1 \Delta p d r 3 \Delta h i s(0.36$ \pm 0.004 ), which was used as a proxy for wild type. For a strain to be classed as sensitive it had to show residual growth below 0.36 at $30 \mu \mathrm{M}$, two standard deviations below $\Delta p d r 1 \Delta p d r 3 \Delta h i s(0.68 \pm 0.065)$.

The 4800 strains were tested in a 1536 strain array format (394x four replicates per plate) as shown in figure 3.7. The strains that have a square box around them have been classified as showing enhanced resistance. The screen was performed with three biological replicates as well as two technical replicates with four colonies of each strain.
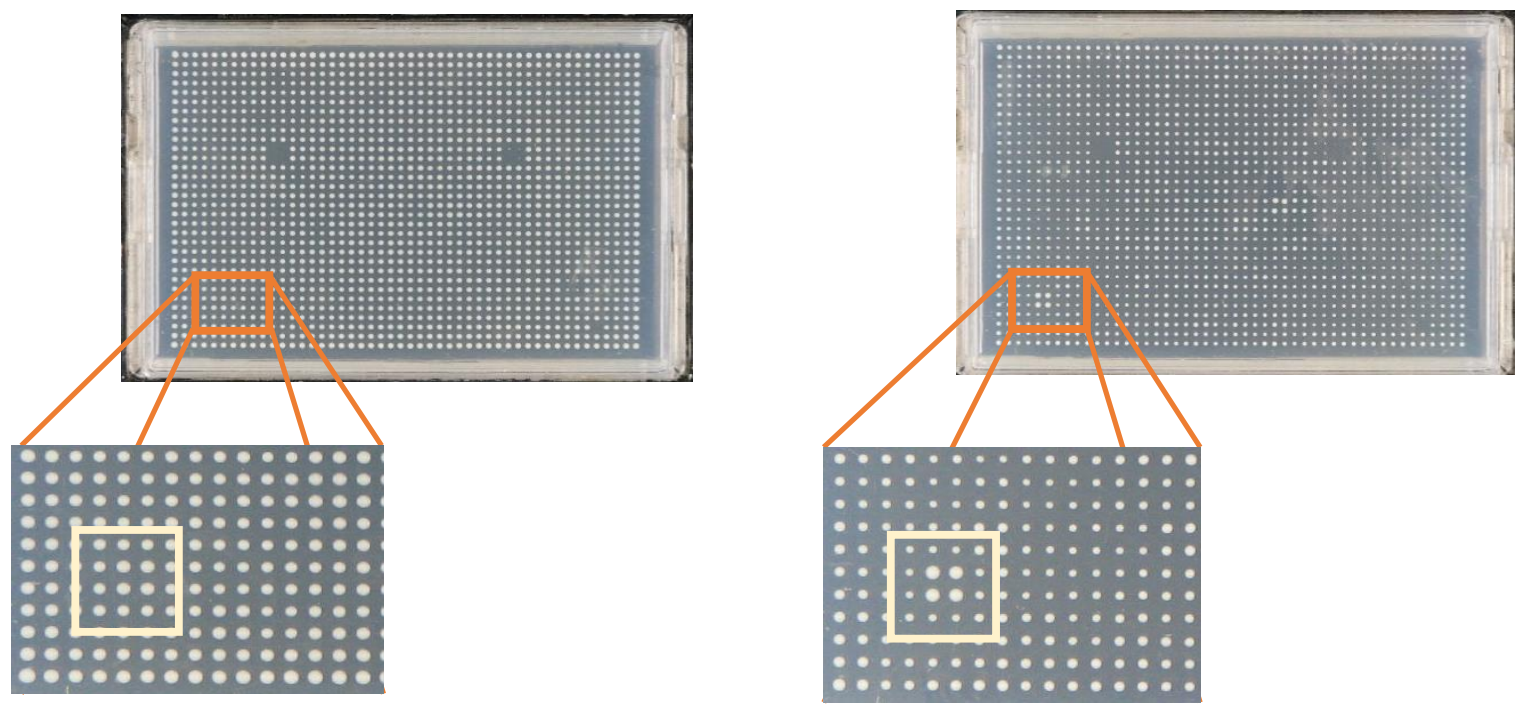

Figure 3.7. Example of a single resistant gene from plate 8, left DMSO control, right benzose $(70 \mu \mathrm{M})$ treated. The 1536 pinned plate consists of 384x four replicates, 309 different single deletion mutants, the border consists of his3 (56x four replicates). 
Of the 4800 strains, 56 were identified as having enhanced resistance. The 56 strains are presented in table 3.3. Of these, 13 were annotated as dubious open reading frames. Notably 25 strains were found to be involved in transcription or translation.

A total of $18 \Delta p d r 1 \Delta p d r 3 \Delta x x x$ sensitive strains were identified (table 3.2). Of the 18, (APL5, ATP1 1, CHO2, CIT1, IRE1, NUP133, OPI3, PDR16, PHO80, RPN4, SAP190, SIP3, SSD1, TGL2, TPM1, YJR087w, YKL207W, and YNR021W) three (YJR087W, YKL207W, and YNR021W) were annotated as dubious open reading frames or uncharacterised; and seven (APL5, CIT1, OPI3, PDR 16, PHO80, SIP3, and TGL2) were annotated as multi drug sensitising (Hillmeyer 1997) deletion strains (frequently flyers as described in section 3.2.3). Of the remaining eight, five (ATP 1 1, IRE 1, NUP133, RPN4 and SSD 1) were found to be involved in transcription or translation.

\begin{tabular}{|c|c|c|}
\hline Systematic name & Alias & Description of biological process \\
\hline YKL207W & AIM27 & $\begin{array}{l}\text { required for efficient folding of proteins in the } \\
\text { ER }\end{array}$ \\
\hline YPL195W & APL5 & $\begin{array}{l}\text { vesicle-mediated transport; protein binding } \\
\text { AP-3 adaptor complex }\end{array}$ \\
\hline YNL315C & ATP 11 & $\begin{array}{l}\text { protein complex assembly; unfolded protein } \\
\text { binding }\end{array}$ \\
\hline YGR157W & $\mathrm{CHO} 2$ & $\begin{array}{l}\text { telomere maintenance; } \\
\text { phosphatidylethanolamine } \mathrm{N} \text { - } \\
\text { methyltransferase activity }\end{array}$ \\
\hline YNR001C & CIT1 & $\begin{array}{l}\text { tricarboxylic acid cycle; citrate (Si)-synthase } \\
\text { activity; mitochondrion }\end{array}$ \\
\hline YHR079C & IREI & $\begin{array}{l}\text { protein amino acid phosphorylation; protein } \\
\text { serine/threonine kinase activity. }\end{array}$ \\
\hline YKR082W & NUP133 & $\begin{array}{l}\text { mRNA export from nucleus; structural } \\
\text { molecule activity; nuclear pore }\end{array}$ \\
\hline YJR073C & OPI3 & phosphatidylcholine biosynthetic process \\
\hline YNL231C & PDR 16 & $\begin{array}{l}\text { response to drug; phosphatidylinositol } \\
\text { transporter activity; cytoplasm }\end{array}$ \\
\hline YOLO01W & $\mathrm{PHO} 80$ & $\begin{array}{l}\text { telomere maintenance; cyclin-dependent } \\
\text { protein kinase regulator activity }\end{array}$ \\
\hline YDL020C & RPN4 & $\begin{array}{l}\text { telomere maintenance; transcription factor } \\
\text { activity }\end{array}$ \\
\hline
\end{tabular}




\begin{tabular}{|l|l|l|} 
YKR028W & SAP190 & $\begin{array}{l}\text { G1/S transition of mitotic cell cycle; protein } \\
\text { serine/threonine phosphatase activity }\end{array}$ \\
\hline YNL257C & SIP3 & $\begin{array}{l}\text { transcription initiation from RNA polymerase II } \\
\text { promoter }\end{array}$ \\
\hline YDR293C & SSD1 & $\begin{array}{l}\text { intracellular mRNA localization; negative } \\
\text { regulation of translation; regulation of fungal- } \\
\text { type cell wall organization }\end{array}$ \\
\hline YDR058C & TGL2 & $\begin{array}{l}\text { lipid metabolic process; triacylglycerol lipase } \\
\text { activity; cellular component }\end{array}$ \\
\hline YNL079C & TPM1 & $\begin{array}{l}\text { pseudohyphal growth; actin lateral binding; } \\
\text { bud neck contractile ring }\end{array}$ \\
\hline YJR087W & $\begin{array}{l}\text { Dubious open reading frame that overlaps } \\
\text { EMC2 which is required for efficient protein } \\
\text { folding }\end{array}$ \\
\hline YNR021W & $\begin{array}{l}\text { biological_process unknown. Localises to the } \\
\text { endoplasmic reticulum }\end{array}$ \\
\hline
\end{tabular}

Table 3.2. Gene deletion strains identified as sensitive in the chemical genomic screen treated with Benzose $(70 \mu \mathrm{M})$. The strains identified as frequent flyers are identified by a grey background.

\begin{tabular}{|l|l|l|}
\hline Systematic name & Alias & Description of biological process \\
\hline YDR524C & AGE1 & $\begin{array}{l}\text { ADP-ribosylation factor GTPase activating } \\
\text { protein effector involved in secretory and } \\
\text { endocytic pathways }\end{array}$ \\
\hline YDR525W & API2 & dubious open reading frame \\
\hline YDR376W & ARH1 & $\begin{array}{l}\text { oxidoreductase of the mitochondrial inner } \\
\text { membrane, involved in cytoplasmic and } \\
\text { mitochondrial iron homeostasis }\end{array}$ \\
\hline YMR116C & ASC1 & $\begin{array}{l}\text { G-protein beta subunit and guanine } \\
\text { nucleotide dissociation inhibitor for Gpa2p }\end{array}$ \\
\hline YLR393W & ATP10 & $\begin{array}{l}\text { mitochondrial inner membrane protein } \\
\text { required for assembly of the F0 sector of } \\
\text { mitochondrial F1F0 ATP synthase } \\
\text { protein involved in buD-site selection }\end{array}$ \\
\hline YFL023W & BUD27 & $\begin{array}{l}\text { possibly to package mRNA for export from } \\
\text { the nucleous; contains RNA-binding motif }\end{array}$ \\
\hline YPL178W & CBC2 & $\begin{array}{l}\text { beta-keto-acyl synthase with possible role in } \\
\text { fatty acid synthesis }\end{array}$ \\
\hline YER061C & CEM1 & $\begin{array}{l}\text { beta regulatory subunit of casein kinase 2 } \\
\text { has many substrates including transcription }\end{array}$ \\
\hline YGL019W & CKB1 &
\end{tabular}




\begin{tabular}{|c|c|c|}
\hline & & factors and all RNA polymerases \\
\hline YKL139W & CTK1 & $\begin{array}{l}\text { catalytic subunit of C-terminal domain of } \\
\text { kinase I, Phosphorylates both RNA pol II to } \\
\text { affect transcription and pre-mRNA 3'end } \\
\text { processing and ribosomal protein }\end{array}$ \\
\hline YBR026C & ETR1 & a probable role in fatty acid synthesis \\
\hline YFL237C & HAP2 & $\begin{array}{l}\text { subunit of the heme-activated, glucose- } \\
\text { repressed HAP } 2 \mathrm{p} / 3 \mathrm{p} / 4 \mathrm{p} / 5 \mathrm{p} \text { CCAAT-binding } \\
\text { complex, a transcriptional activator and } \\
\text { global regulator of respiratory gene } \\
\text { expression }\end{array}$ \\
\hline Control & HIS3 & $\begin{array}{l}\text { imidazoleglycerol-phosphate dehydratase, } \\
\text { catalyzes the sixth step in histidine } \\
\text { biosynthesis; mutations cause histidine } \\
\text { auxotrophy and sensitivity to Cu, Co, and Ni } \\
\text { salts; transcription is regulated by general } \\
\text { amino acid control via GCN4p }\end{array}$ \\
\hline YDR528W & HLRI & $\begin{array}{l}\text { regulation of cell wall composition and } \\
\text { integrity and response to osmotic stress }\end{array}$ \\
\hline YHR187W & IPK 1 & $\begin{array}{l}\text { Inositol 1,3,4,5,6-pentakisphosphate 2-kinase, } \\
\text { nuclear protein required for synthesis of } \\
1,2,3,4,5,6 \text {-hexakisphosphate (phytate), } \\
\text { which is integral to cell function; has } 2 \text { motifs } \\
\text { conserved in other fungi }\end{array}$ \\
\hline YGL086W & MADI & $\begin{array}{l}\text { coiled-coil protein involved in the spindle- } \\
\text { assembly checkpoint }\end{array}$ \\
\hline YDR005C & MAF1 & $\begin{array}{l}\text { highly conserved negative regulator of RNA } \\
\text { polymerase III }\end{array}$ \\
\hline YRP070W & MED2 & $\begin{array}{l}\text { subunit of the RNA polymerase mediator } \\
\text { complex; essential for transcriptional } \\
\text { regulation }\end{array}$ \\
\hline YFR034C & $\mathrm{PHO} 4$ & $\begin{array}{l}\text { basic helix-loop-helix transcription factor of } \\
\text { the myc-family; activates transcription } \\
\text { cooperatively with } \mathrm{PHO} 2 \mathrm{p}\end{array}$ \\
\hline YDR276C & PMP3 & $\begin{array}{l}\text { small plasma membrane, deletion causes } \\
\text { hyperpolarization of the plasma membrane }\end{array}$ \\
\hline YPL157W & QCR2 & $\begin{array}{l}\text { subu+A21:D40nit } 2 \text { of the ubiquinol } \\
\text { cytochrome-c reductase complease } \\
\text { involved in electron transport chain }\end{array}$ \\
\hline YER083C & RMD5 & $\begin{array}{l}\text { somponent of GID Complex that confers } \\
\text { ubiquitin ligase (U3) activity; necessary for } \\
\text { polyubiquitination and degradation of the } \\
\text { gluconeogenic enzyme fructose-1,6- } \\
\text { bisphosphatase }\end{array}$ \\
\hline YFR048W & RMD7 & $\begin{array}{l}\text { involved in insertion of proteins into the ER } \\
\text { membrane; required for the retrieval of HDEL } \\
\text { proteins from the Golgi and ER }\end{array}$ \\
\hline
\end{tabular}




\begin{tabular}{|c|c|c|}
\hline YBL027w & RPL19b & ribosomal 60s subunit protein \\
\hline YPR043W & RPL43A & ribosomal 60s subunit protein \\
\hline YLL045C & RPL8B & ribosomal 60 S subunit protein L8B \\
\hline YJL191W & RPS14b & $\begin{array}{l}\text { protein component of the small ( } 40 \mathrm{~S}) \\
\text { ribosomal subunit; required for ribosome } \\
\text { assembly and } 20 \mathrm{~S} \text { pre-rRNA. }\end{array}$ \\
\hline YNL302C & RPSIa & $\begin{array}{l}\text { ribosomal protein } 10 \text { (RP10) of the small (40S) } \\
\text { subunit }\end{array}$ \\
\hline YPL090C & RPS6A & ribosomal 40s subunit protein \\
\hline YBL025W & RRN10 & $\begin{array}{l}\text { protein involved in promoting high level } \\
\text { transcription of rDNA, subunit of UAF for RNA } \\
\text { polymerase I }\end{array}$ \\
\hline YNL254C & RTC4 & $\begin{array}{l}\text { protein of unknown function; null mutation } \\
\text { suppresses CDC 13-1 temperature sensitivity; }\end{array}$ \\
\hline YDL225W & SHS1 & $\begin{array}{l}\text { component of the septin ring that is required } \\
\text { for cytokinesis; septins are GTP-binding } \\
\text { proteins that assemble into rod-like hetero- } \\
\text { oligomers that can associate with other rods } \\
\text { to form filaments }\end{array}$ \\
\hline YBR289W & SNF5 & $\begin{array}{l}\text { subunit of the SWI/SNF chromatin } \\
\text { remodeling complex; involved in } \\
\text { transcription regulation }\end{array}$ \\
\hline YHR008C & SOD2 & protects cells against oxygen toxicity \\
\hline YGL127C & $\mathrm{SOH} 1$ & $\begin{array}{l}\text { subunit of the RNA polymerase II mediator } \\
\text { complex; assacoiates with core polymerase } \\
\text { subunits to form the RNA polymerase II } \\
\text { holoenzyme; involved in telomere } \\
\text { maintenance }\end{array}$ \\
\hline YMR179W & SPT2 & $\begin{array}{l}\text { protein involved in negative regulation of } \\
\text { transcription }\end{array}$ \\
\hline YER 161C & SPT21 & $\begin{array}{l}\text { protein with a role in transcriptional silencing; } \\
\text { required for normal transcription at several } \\
\text { loci including HTA2-HTB2 and HHF2-HHT2, but } \\
\text { not required at the other histone loci }\end{array}$ \\
\hline YOR247W & SRL 1 & $\begin{array}{l}\text { mannoprotein that exhibits a tight } \\
\text { association with the cell wall, required for } \\
\text { cell wall stability in the absence of GPI- } \\
\text { anchored mannoproteins }\end{array}$ \\
\hline YGLO24W & SST3 & $\begin{array}{l}\text { dubious open reading frame unlikely to } \\
\text { encode a protein that overlaps with PGD } 1 \text {, a } \\
\text { RNA polymerase II mediator, and STE } 18 \\
\text { involved in mating signalling. }\end{array}$ \\
\hline YPR 191W & TGS 1 & $\begin{array}{l}\text { trimethyl guanosine synthase; required for } \\
\text { nucleolar assembly and splicing of meiotic } \\
\text { pre-mRNAs }\end{array}$ \\
\hline YDR354W & TRP4 & $\begin{array}{l}\text { anthranilate phosphoriboyl transferase of } \\
\text { the trytophan biosynthetic pathay. }\end{array}$ \\
\hline
\end{tabular}




\begin{tabular}{|c|c|c|}
\hline YPR066W & UBA3 & $\begin{array}{l}\text { protein that acts together with ULAlp to } \\
\text { activate RUBlp before its conjugation to } \\
\text { proteins which may play a role in protein } \\
\text { degradation }\end{array}$ \\
\hline YDR092W & UBC13 & $\begin{array}{l}\text { Ubiquitin-conjugating enzyme involved in } \\
\text { the error-free DNA postreplication repair } \\
\text { pathway; interacts with MMS2p to assemble } \\
\text { ubiquitin chains at the Ub Lys-63 residue; } \\
\text { DNA damage triggers redistribution from the } \\
\text { cytoplasm to the nucleus }\end{array}$ \\
\hline YER151C & UBP3 & $\begin{array}{l}\text { Ubiquitin-specific protease involved in } \\
\text { transport and osmotic response; interacts } \\
\text { with Bre5p to co-regulate anterograde and } \\
\text { retrograde transport between the ER and } \\
\text { Golgi; involved in transcription elongation in } \\
\text { response to osmostress through } \\
\text { phosphorylation at Ser695 by HOG p }\end{array}$ \\
\hline YNL197C & WHI3 & $\begin{array}{l}\text { RNA binding protein that sequesters CLN3 } \\
\text { mRNA in cytoplasmic foci; Tpk1 (PKA) } \\
\text { mediated phosphorylation of WHI3 affects } \\
\text { the G1/S phase transition by modulating } \\
\text { CLN3 transcription }\end{array}$ \\
\hline YDR250C & & $\begin{array}{l}\text { dubious open reading frame unlikely to } \\
\text { encode a protein }\end{array}$ \\
\hline YGL036W & & $\begin{array}{l}\text { dubious open reading frame unlikely to } \\
\text { encode a protein }\end{array}$ \\
\hline YLR365W & & $\begin{array}{l}\text { dubious open reading frame unlikely to } \\
\text { encode a protein }\end{array}$ \\
\hline YLR366W & & $\begin{array}{l}\text { dubious open reading frame unlikely to } \\
\text { encode a protein which overlaps RPS22B }\end{array}$ \\
\hline YNL170W & & $\begin{array}{l}\text { dubious open reading frame unlikely to } \\
\text { encode a protein. Overlaps with PSDI } \\
\text { (Phosphatidylserine decarboxylase) }\end{array}$ \\
\hline YPL257W & & $\begin{array}{l}\text { putative protein of unknown function; } \\
\text { homozygous diploid deletion strain exhibits } \\
\text { low budding index }\end{array}$ \\
\hline
\end{tabular}

Table 3.3. Genes deletion strains identified as resistant in the chemical genomic screen treated with Benzose $(70 \mu \mathrm{M})$ 


\subsubsection{Validation of high throughput results}

High throughput assays are prone to errors. False positives, where sensitivity or resistance is erroneously indicated, can be identified by careful validation of the identified deletion strains. Such false positives can arise from a number of sources. Competition can cause a decrease in growth, when normal growing yeast is situated next to fast growing strains or an apparent increase when neighbouring a slower growing stain. Also mispinnings lead to colonies where fewer cells were collected during pinning, leading to apparent reduced growth across a quadruplet for a strain. Finally it is unclear if the breakdown product(s) observed in section 3.4.6, may have an effect on some strains of yeast. For these reasons it was decided to validate the resistant and sensitive strains in liquid SC culture.

\subsubsection{Validation of Resistant strains}

The validation of the resistant strains were undertaken as described in section 3.3.16 of the methods. Of the 56 validated strains assessed, 34 strains showed enhanced resistance compared to the $\Delta$ his3 control to 50 $\mu \mathrm{M}$ benzose in SC culture, shown in graph 3.9 and an example of the resistance against HIS control is shown in figure 3.8. No further studies were completed to determine the precise $\mathrm{IC}_{50}$ of any resistant strain. 


\section{$\triangle T$ TGS1 $\quad \Delta \mathrm{HIS3}$}

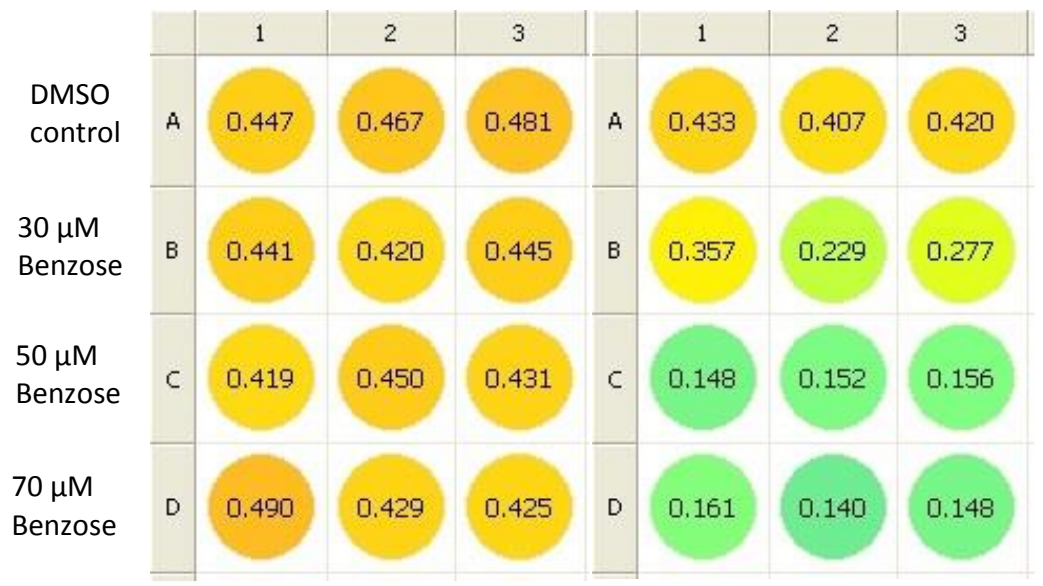

Figure 3.8. Sample of resistant validations from the chemical genetic screen. Each strain was subjected to three concentrations of benzose $(30,50,70 \mu \mathrm{M})$. Strains that showed residual growth greater than 0.400 at $50 \mu \mathrm{M}$ treatment of benzose (10 stdev of $\triangle H I S 3$ control average) were classed as resistant. $\triangle T G S 1$ shows resistance against benzose at all concentrations of benzose, at $50 \mu \mathrm{M} \triangle T G S 1$ has an average (three replicates) residual growth of $0.932 \pm 0.016$ at least 0.5 greater than $\Delta H I S 3$.

\subsubsection{Validation of sensitive strains}

The validation of the sensitive strains was carried out as described in section 3.3.16 of the methods. All 18 strains that were identified as sensitive in the high throughput screen validated as sensitive in SC media (OPI3, CIT1, APL5, YKL207W, TGL2, PHO80, SIP3, PDR16, SAP190, YNR021W, YJR087W, CHO2, IRE1, ATP11, TPM1, RPN4, SSDI and NUP133). The validation of these sensitive strains was undertaken with lower benzose concentrations; $50-10 \mu \mathrm{M}$. The results showed that four of these strains were sensitive below $10 \mu \mathrm{M}$. 


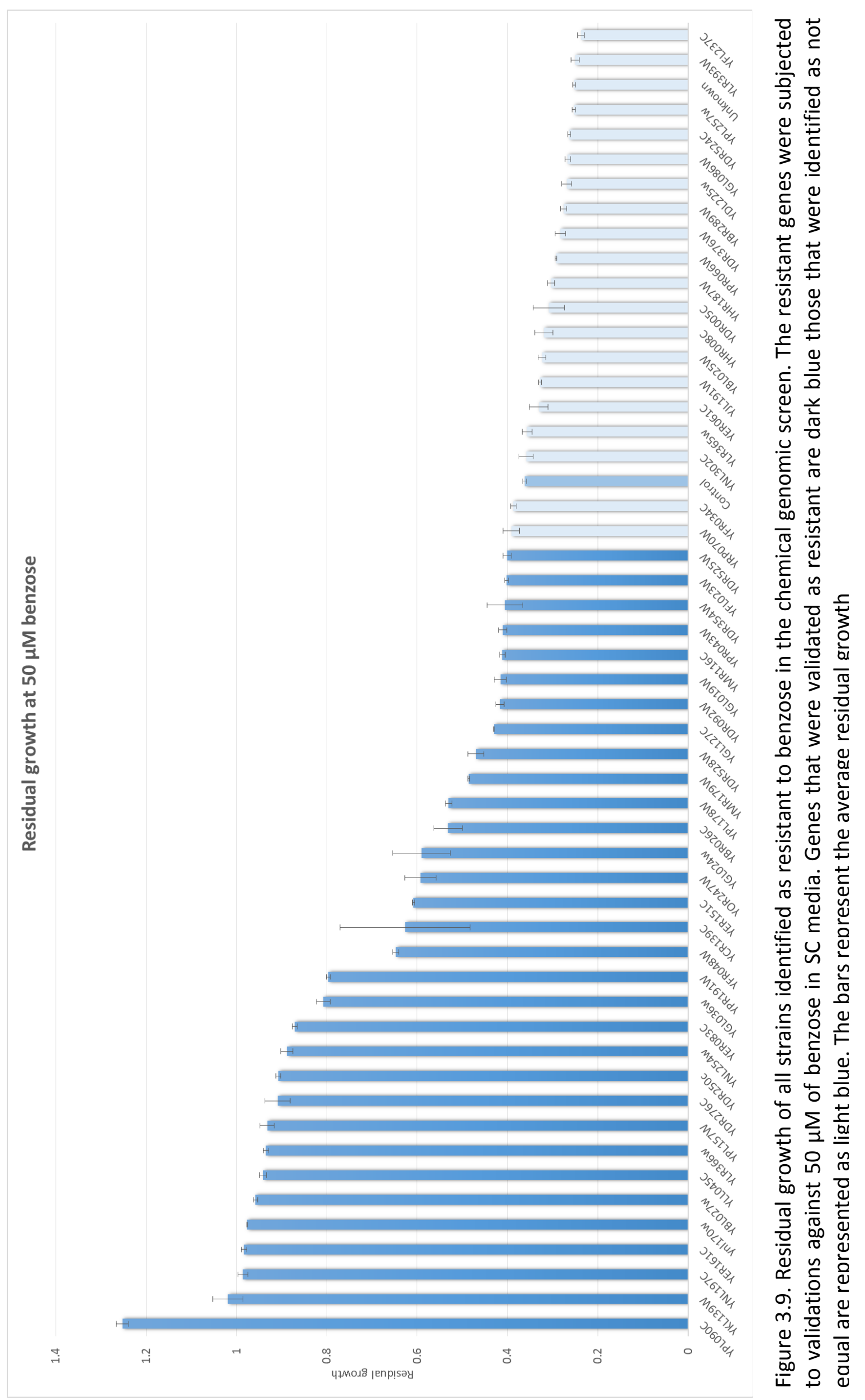




\subsubsection{Benzose has no effect on the unfolded protein response}

In order to determine if the unfolded protein response (UPR) was activated by benzose treatment, YCG266-4XUPRE-GFP yeast cells were treated with the compound and examined for UPR activation via confocal microscopy. Benzose treated cells were compared to cells treated with a known UPR inducer, dithiotheritol (DTT). No evidence was seen for induction of the UPR by treatment with benzose.

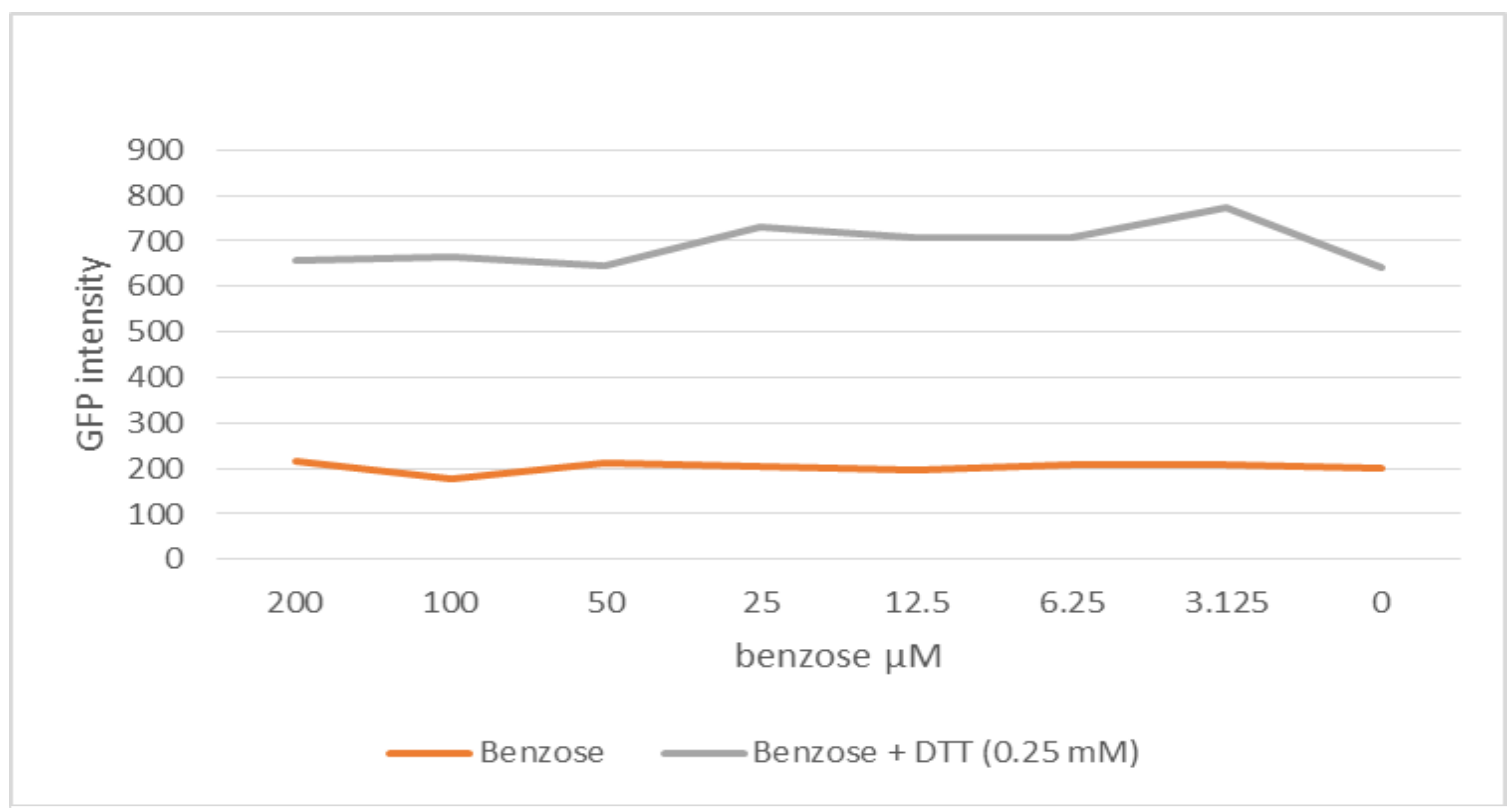

Figure 3.10. UPR assay to determine protein misfolding, benzose showed no increase in protein folding. DTT was used as a control, as it is a known protein misfolding inducer. Whole cell GFP intensity, measured at $520 \mathrm{~nm}$, increases with concentration in DTT treated cells, indicating UPR activation. GFP intensity remains relativity constant in benzose treated cells, indication a non-existent response.

\subsubsection{Antibiotic assay}

Current experiments have shown no activity in bacteria (E. coli DH5a and Psa-V 18800). 


\subsection{DISCUSSION}

This project identified a range of biologically active compounds. The library of compounds synthesised consisted mainly of cyclopropanecarbohydrates with a range of glucal precursors and by-products. This library was screened for inhibitory biological activity for mechanism and mode of action studies in S. cerevisiae. Twenty-seven compounds were synthesised and screened for inhibitory activity, producing five active compounds.

Of the synthetic compounds identified as active, the most potent was found to be benzose, therefore, was selected for further study.

\subsubsection{Dose response assays}

A series of dose response assays were carried out in SC broth against $S$. cerevisiae BY4741 and $\Delta p d r 1 \Delta p d r 3$ strains to determine the characteristics of the studied compounds with regards to general toxicity.

A liquid phase response assay showed that benzose, and compounds 11, 15, 20 and 27 inhibited yeast growth in the low to mid micromolar range. Benzose inhibited all cell growth with an $I C_{50}$ concentration of $40 \mu \mathrm{M}$ in the $\Delta p d r l \Delta p d r 3$ strain, but was inactive against BY4741, identifying efflux pumps as having an effect on toxicity. Benzose was shown to have no activity against human cell lines $\mathrm{HL}-60$ and 1A-9. Furthermore benzose was also found to have no activity as an antibacterial agent.

The $\Delta p d r 1 \Delta p d r 3$ strain has a reduced ability to efflux xenobiotics through ATP-binding cassette $(A B C)$ transporters (Taibi \& Taymound, 1999). The major $A B C$ transporters are able to export a wide range of substrates (Jungwirth \& Kuchler, 2006) and the structure and hydrophobicity of benzose fits the character of an $A B C$ transporter substrate. For many 
drugs, including benzose, the PDR1 + PDR3 combined deletions are sufficient to increase the sensitivity of the cell (Nourani et al. 1997; Rogers et al. 2001). PDR1 and PDR3 are genes that produce transcription factors that are considered to be master regulators of the pleiotropic drug resistance systems, which includes the major $A B C$ efflux pumps (Onda et al. 2004). These multideleted knock-outs are therefore sensitive to a wide array of compounds and can be used for screens to identify weaklyactive lead structures which can often be missed by classic drug screening (Rogers et al. 2001). The yeast $\Delta p d r 1 \Delta p d r 3 \Delta x x x$ library was used as it is a valuable tool for the genomic screening, coupling its increased sensitivity with the utility of a deletion library for revealing chemical genetic profiling to probe benzose's mode of action (Ferrari et al. 2010; Coorey, 2012). The $\Delta p d r 1 \Delta p d r 3$ and BY4741 dose response was further utilised to identify whether benzose acts in a cytostatic or cytotoxic manner.

\subsubsection{Cytostatic and cytotoxic}

In the initial dose response assays with benzose, only partial inhibition of growth was observed for the PDR-deficient strain $\Delta p d r 1 \Delta p d r 3$ between 0.1 $\mu \mathrm{M}$ to $1000 \mu \mathrm{M}$ (section 3.4.2). Growth was only observed at $0.1 \mu \mathrm{M}$ to 100 $\mu \mathrm{M}$ concentrations while $314 \mu \mathrm{M}$ showed no signs of growth beyond the second cell dilution. This may be due to irreversible inhibition of growth at high concentrations but a reversible inhibitory effect at lower concentrations. This has been previously reported in literature (Van Goietsenoven et al. 2012; Dumont et al. 2007). For example, narciclasine, a potent eEFla inhibitor, induces cytotoxic mitochondrial apoptosis at $\geq 200 \mathrm{nM}$ whereas cytostatic impairment of actin cytoskeleton organisation is induced at $50 \mathrm{nM}$ (Van Goietsenoven et al. 2012; Dumont et al. 2007). The results above suggest that, like narciclasine, benzose is exhibiting both cytostatic and cytotoxic effects.

The remaining compounds did not show activity or have any effect at low enough concentration to be considered as further lead compounds. However, the dose response assay was able to give insight into the biological mechanism through structure activity relationships. 


\subsubsection{Structure activity relationship of cyclopropanated carbohydrates}

The structures and properties of each of the five active compounds (benzose, 11, 15, 20 and 27) against $\Delta p d r 1 \Delta p d r 3$ were analysed to assess why they have different levels of biological activity. Five of the 27 compounds synthesised were active against $\Delta p d r l \Delta p d r 3$, with benzose being the most active $(40 \mu \mathrm{M})$. However only one, $17(0.4 \mathrm{mM})$ was active against BY4741 (S. cerevisiae), as described in section 3.4.1. To understand the activity the compounds will be discussed in turn based on the three proposed mechanisms discussed (section 1.4.2).

The following assumptions are also made in this analysis;

I) All compounds share the same target; and

II) the compounds function through covalent interactions with their target or, must be covalently modified prior to interaction with their target.

Given a proteins' ability to catalyse reactions, the inherent activity of an individual substrate may be masked. Thus activity will arise from a combination of a compound's ability to bind to the target and its ability to undergo the appropriate transformation.

\subsubsection{Mechanism 1}

As introduced in sections 1.4.1 and 2.2.1, the cyclopropane is a strained three-membered ring that is susceptible to nucleophillic attack. Of the active compounds (benzose, 11, 15, 20, 27), all have a cyclopropane and all can undergo the proposed ring breaking mechanism (scheme 3.1). For a compound to go via this mechanism it must be able to stabilise a carbanion, and have a good leaving group on the cyclopropane (Hewitt \& Harvey, 2008). All five active compounds are able to fulfil these attributes. Compound $\mathbf{1 5}$ is the only one of the five active compounds that has a dibromocyclopropane. Bromines are large halogens that act as very good leaving groups (Bartoli \& Todesco, 1977), however their ability to 
stabilise a carbanion, is not to the same degree as chlorine (Bickelhaupt et al. 2005). It has computational been shown computationally by Bickelhaupt et al. (2005) that a-stabilization of the carbanion by $\mathrm{CH}_{2} \mathrm{X}$ - is strongest for fluorine and become less so along the series $\mathrm{X}=\mathrm{F}, \mathrm{Cl}, \mathrm{Br}$ and I. This is shown to follow the observed decrease in basicity of $\mathrm{CH}_{2} \mathrm{X}$ - along this series, the reduced basicity corresponds to a decrease in proton affinity of $\mathrm{CH}_{2} \mathrm{X}$. When applying this computational model to the anion stabilisation proposed in mechanism 1, it would be expected that the dibromine will be less active than the dichlorocyclopropane-carbohydrate. This is seen in the difference in activity between benzose and $\mathbf{1 5}$. The monochlorocyclopropane $\mathbf{1 1}$ is eight-fold less active than benzose. This change in activity can be attributed to the removal of one of the two chlorides from benzose. The loss of a chloride would reduce the effect of carbanion stabilisation (Brinkman et al. 1994), resulting in lower activity. Furthermore, the activity of 11 is less than 15, which adheres to the stabilisation of the carbanion effect, two bromines have a greater stabilisation effect over a single chlorine.

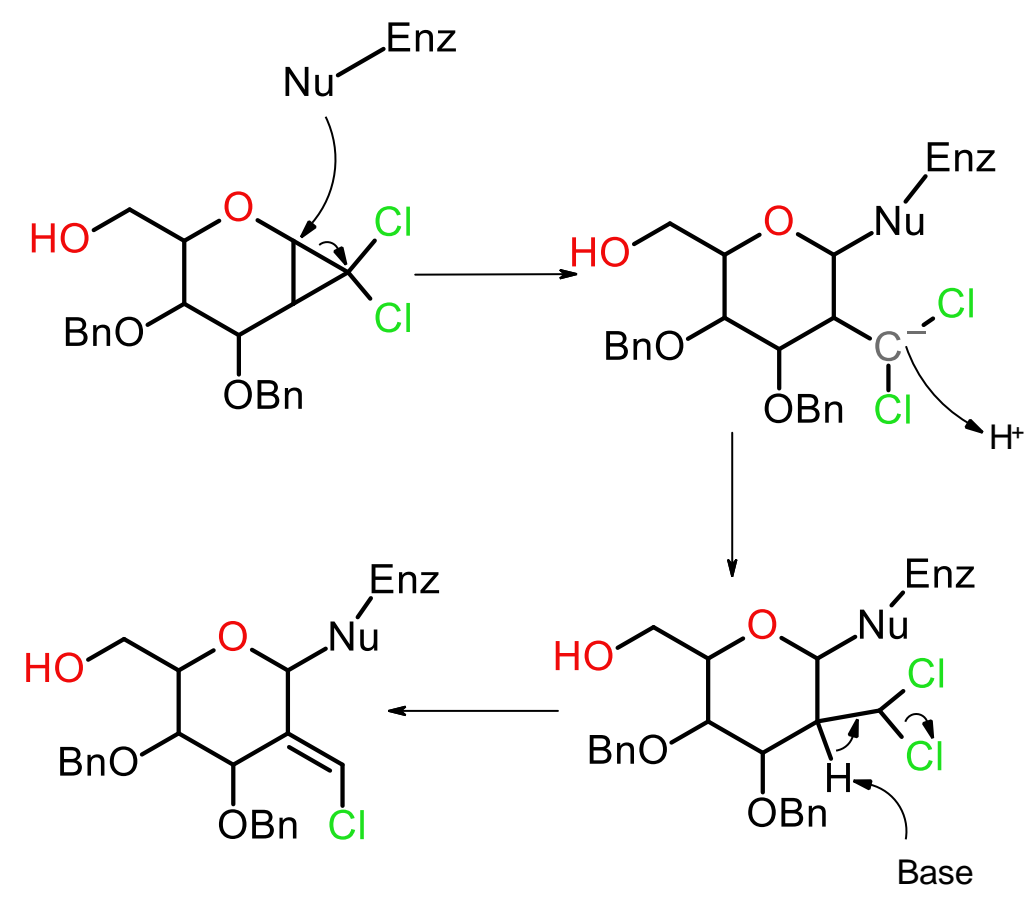

Scheme 3.1. Mechanism 1 


\subsubsection{Mechanism 2}

The two proposed ring opening mechanisms may be operating, however the evidence is presently against this. Scheme 3.2 shows the loss of a substituent of the cyclopropane in a Ferrier-like rearrangement, for this to occur the substituents on the cyclopropane must be good leaving groups, this is the case. However a bromine is a much better leaving group than chlorine (Alonso \& Rossi, 1980) so it would be expected 15 would be more reactive then benzose, this is not the case as shown in section 3.4.3. Therefore, it is doubtful that this is the mechanism of action.

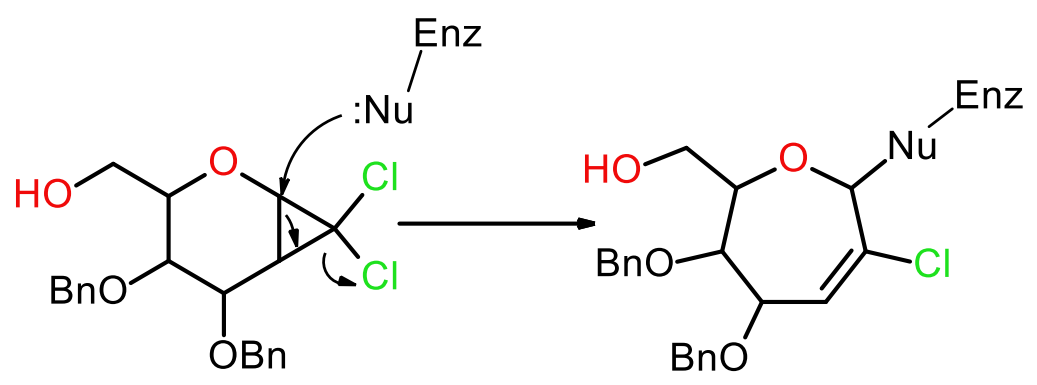

Scheme 3.2. Mechanism 2 


\subsubsection{Mechanism 3}

The mechanism shown in scheme 3.3 is similar to the above, however in this case the leaving group is on the C-3 position. Compounds 11, 15 and benzose all have an $\mathrm{OBn}$, which can act as a leaving group when activated by an electrophile (Rooseboom et al. 2004). However two of the five compounds have a hydroxyl group, which is a very poor leaving group (Qin et al. 2007). Although catalytic activation by the protein target may permit this transformation, it remains less likely.

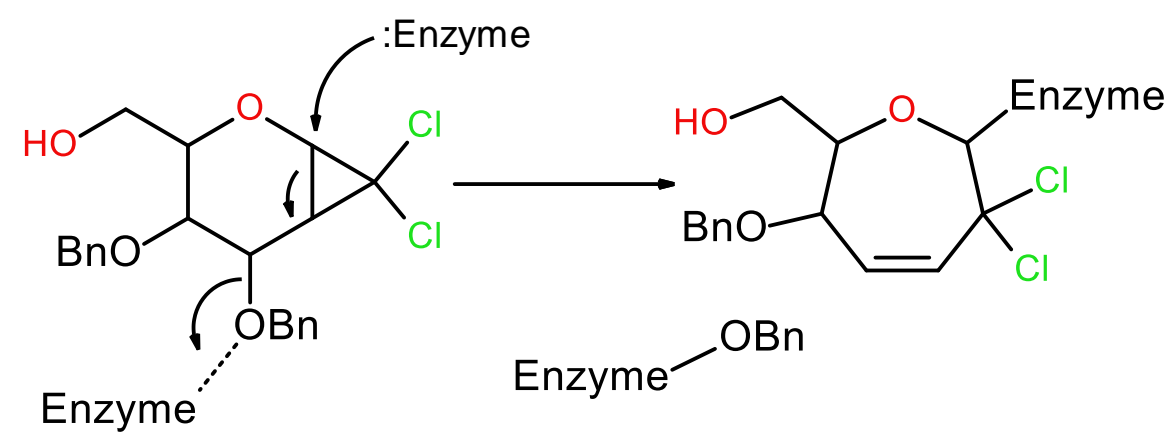

Scheme 3.3. Mechanism 3

At this point the evidence discussed here is pointing towards the carbanion intermediate mechanism, as depicted in scheme 3.1.

The orientation of the cyclopropane proved to be important for activity as all five active compounds had the cyclopropane in the "down" position (ie on the same face as the C-6 substituent of the pyran), whereas the stereoisomers in the "up" position showed no activity. This effect could be caused by multiple factors. Sterics play an important part of all drug design. If the structure does not fit with the target it will not be active. For example a study by Carotti et al. (2002) demonstrated that removing the methyl group in the $3^{\prime}$ position of geiparvarin increased its level of inhibition of monoamine oxidase. This was due to reduction in the steric hindrance. Todoroki et al. (1996) showed that the "down" unfunctionalised cyclopropane of abscisic acid analogues was inactive against the 
stomatal opening of the epidermal strips of spidenwort, lettuce seed germination, a-amylase induction by gibberellin A-3 in barley half-seeds and elongation of the second leaf sheath of rice seedlings, whereas the "up" cyclopropane was active, the difference in activity was contributed to the stereochemistry of the cyclopropane in a tight binding pocket.

\subsubsection{C-6 hydroxyl is needed for activity}

Benzose has a C-6 hydroxyl, it was found that when this was protected by either a trityl $\mathbf{5}$, formate ester $\mathbf{8}$ or benzyl $\mathbf{2 9}$ the activity is completely lost (exluding $\mathbf{2 5}$ for reasons later discussed). This suggests either an unfavourable steric interaction or that $\mathrm{H}$-bonding is required for activity. Interestingly, 25 which retains OTr but lacks a C-3 OBn is somewhat active, albeit at a five-fold higher concentration than benzose. This may be because of hydrogen bonding within the pocket as both the C-3 hydroxyl and C-6 hydroxyl may be able to interact with the same hydrogen bond acceptor shown in figure 3.11. The enzyme acts as a hydrogen bond donor and the compound the acceptor because compound 9 with the formate esters would be able to accept a hydrogen bond, however it is

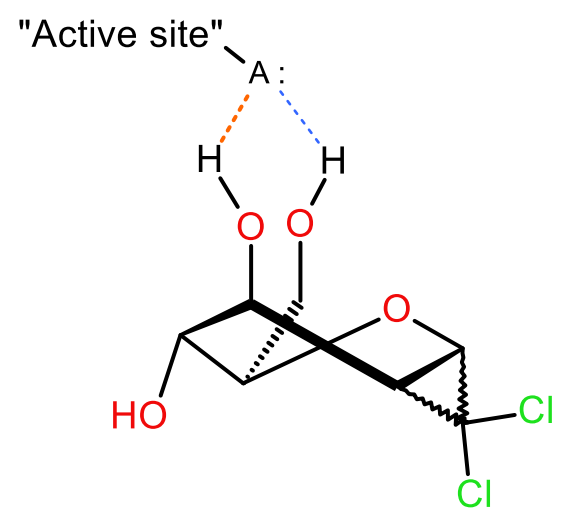

Figure 3.11. Proposed hydrogen bonding in the active site with C-3 and C-6 hydroxyl. A: represents the hydrogen acceptor in the hydrogen bond formation. The blue hydrogen bond represents compounds; 9, 11, 15, 16, 18, 24, 27, 26 and benzose, the orange hydrogen bond represents compounds; 25, 27 and 26. 
inactive.

Surprisingly, $\mathbf{2 4}$ was found to be inactive due to the addition of an azide in the para-position of the benzyl group. This suggests that the benzyl protecting groups are situated inside the active site pocket.

In all cases of activity the cyclopropane was in the "down" position and the "up" was always found to be inactive. It is proposed that benzose is in a tight-binding enzymatic pocket, and the enzymatic nucleophile is attacking the anomeric centre (C-1), and is positioned so it can undergo nucleophillic attack at the required angle as shown in figure 3.12. However, in the proposed position with compound 8 the nucleophile would be unable to attack the "up" cyclopropane, resulting in inactivity.
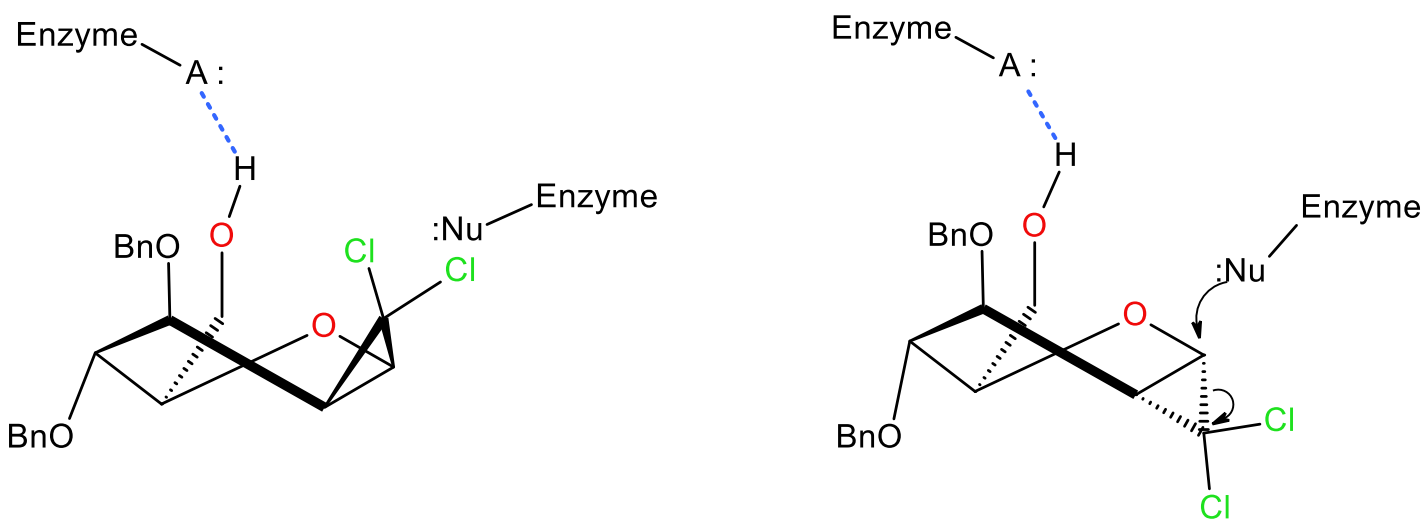

Figure 3.12. Proposed nucleophilic attack of the aromatic centre of compound 9 and benzose. Benzose is active, whereas 9 is inactive suggesting steric hindrance as a factor, or the nucleophile is situated at an angle that can attack the "down" cyclopropane but not the "up" cyclopropane. A: represents the proton acceptor in the hydrogen bond formation (Nitrogen or Oxygen), Nu: represents the nucleophile attacking the aromatic centre. 


\subsubsection{The chemistry of benzose}

It is possible, as we have seen in the structure activity relationships of the cyclopropanated-carbohydrates and their precursors, to predict their chemistry within a cell. There are several determinations that can be made about benzose in this manner. Benzose (1,5-Anhydro-3,4-di-Obenzyl-2-deoxy-1,2-C-(dichloromethylene)-D-glycero-D-gulo-hexitol) is a non-polar, cyclopropanated carbohydrate. The apparent affinity of the compounds for $A B C$ transporters suggests that the toxicity of benzose is limited by the detoxification pathways of the cell. This was expected as benzose had been designed to be highly selective with its target. The proposed mechanism of benzose (scheme 3.4) shows that ring breaking will not occur unless the structural requirements are met. This is further backed up by the SAR analysis that shows the addition of either an azide, C-6 hydroxyl protecting group, or "up" cyclopropane results in full loss of activity.

The mechanism proposed in scheme 3.4 would see the nucleophile within the targets active site being irreversibly bound to benzose. The nucleophile attacks at C-1, results in ring breaking and the formation of a stabilised anion, which is stabilised by the two chlorines. Through acid-base catalysis, the anion attacks a proton, a base attacks the C-2 proton with results in the formation of an alkene and elimination of chlorine. However, this mechanism can stop once C-7 has been protonated.

This reaction could have a range of deleterious effects including covalent modification of the proteins structure, blocking the active site, or interfering with protein-protein interactions (Way, 2000; Johnson, 2004; Stadtman, 1990). Covalent modification may not be occurring if the protein is attacking the cyclopropane via an activated water molecule (Liu et al. 1995). This mechanism will still occur although benzose will not irreversibly bind to the protein. 
Benzose is non-polar with a polar alcohol region, which is likely to form hydrogen bonds within the active site of the enzyme. Non-polar drugs are able to diffuse through the phospholipid bilayer membrane (Schwendener \& Schott, 2010), meaning they are able to be incorporated into the cell without the need of active transport. Hydrophobic compounds are more likely to be "drug-like" as they have a high ligand-lipophilic efficiency score which is associated with drug-likeness (Leeson \& Springthorpe, 2007). Ligand-lipophilic efficiency is a parameter used to link potency and lipophilic nature associated with a compound to estimate its potency as a 
drug.

The proposed mechanism of benzose suggests a likely pathway of how the compound acts to inhibit yeast survival. The primary biological effect of toxicity suggests that inhibition of cellular growth is a result of selective inhibition of an essential protein.

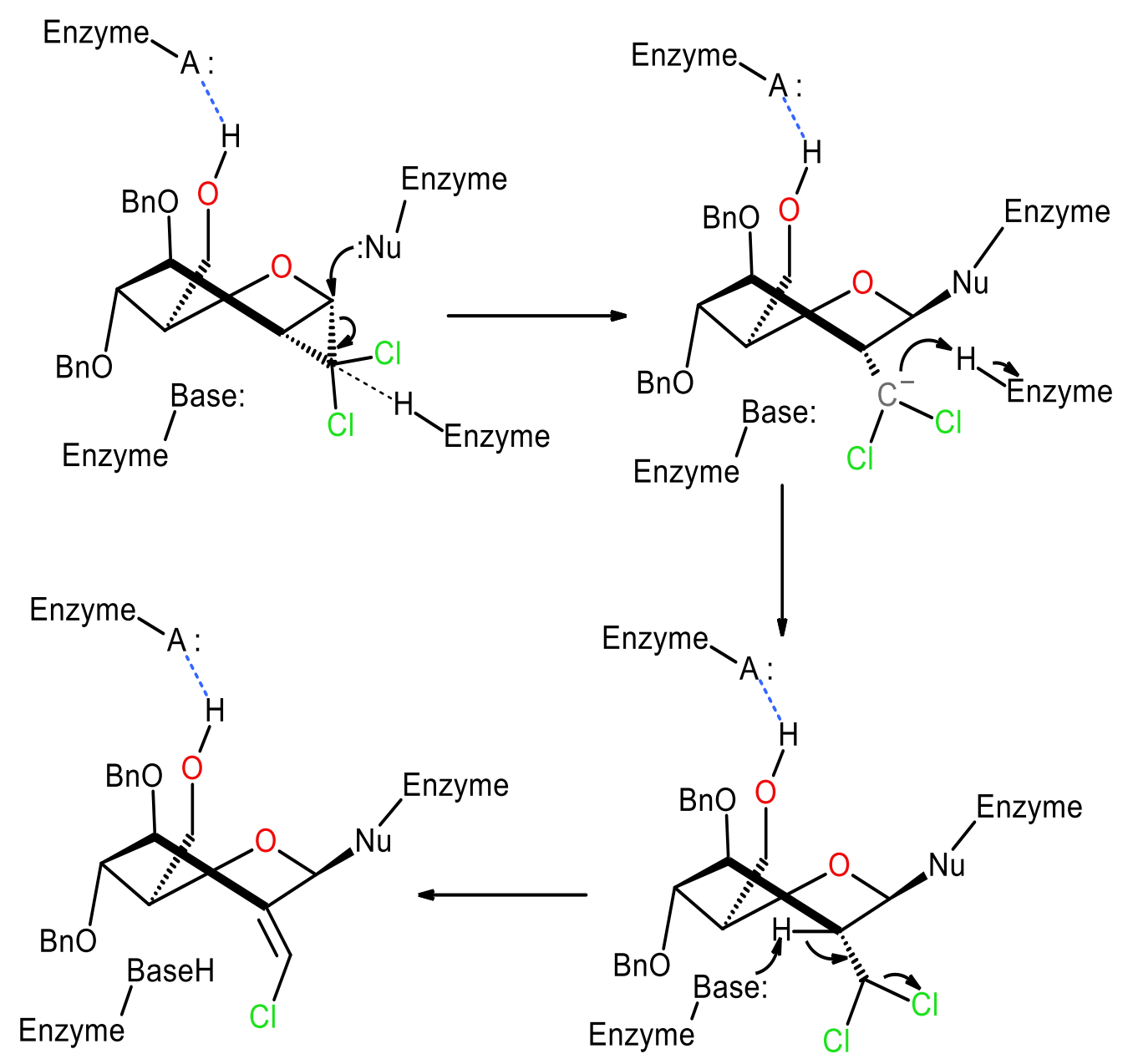

Scheme 3.4. The proposed enzymatic step of benzose within the active site of an unknown protein, where a nucleophile is present that is able to attack the C-1 (anomeric) position. The addition of the nucleophile causes the cyclopropane to break resulting in the rearrangement of bonds forming a stabilised anion, which is then able to attack a proton then elimination of $\mathrm{H}-2$ by a base and elimination of $\mathrm{Cl}$. 


\subsubsection{Alkyne-substituted sepharose matrix}

This study was undertaken to identify possible methods of attaching benzose to a resin in order to create a tool for identification of potential benzose-interacting proteins. The investigation yielded a possible method of attachment and also a method to identify whether the chemistry was viable, as described in results section 3.4.4.

Through testing a range of cyclopropane-containing glycosides and glucals for activity against $\Delta p d r 1 \Delta p d r 3$, benzose was found to be the most promising candidate for pull-down studies due to the low micromolar activity. However there were no suitable points of attachment on benzose for the matrix attachment, as any modification to the C-6 hydroxyl would most likely cause loss of activity as shown by $\mathbf{6 , 9}$ and $\mathbf{3 0}$ in the SAR as previously mentioned in 3.5.2.

Therefore a strategy was proposed to add the attachment point to the C3 or C-4 hydroxyl. A viable option was the use of p-azidobenzyl as it is already similar to the benzyl on the C-3 and C-4 hydroxyl and has been previously used to attach a photoaffinity probe (Young, 1983). Additionally the $p$-azidobenzyl could undergo a Huisgen Cyclisation reaction, within a cell lysate, to a corresponding alkyne resin leading to identification of the biological target (Wang et al. 2009). By doing so it would overcome the problem of binding benzose to a matrix. Azides are small and have no biological effect and was anticipated to have little effect on the binding of benzose. Compound $\mathbf{2 4}$ was therefore synthesised as a tool to identify the likely target(s) of benzose.

It was decided to modify an epoxy-activated sepharose 6B resin to an alkyne-substituted sepharose resin. The epoxy-activated sepharose resin has an advantageous 13-atom spacer which is linked to an epoxide through which an alkyne can be attached. It has also been reported that alkyne-modified probes display suitable stability for profiling enzyme 
activities in cells (Speers \& Cravatt, 2004), as they can undergo the Huisgen Cyclisation with azide-containing compounds such as $\mathbf{2 4}$.

The epoxide matrix was treated with three different alkyne derivatives to determine which would lead to a desired alkyne-substituted sepharose matrix. The short optimised synthesis of the alkyne- substituted sepharose $6 \mathrm{~B}$ resulted from the propargylation of 3-aminopropan-1-ol with propargyl bromide. Two other amines were also tried but they did not present a viable option. The amines were too volatile, which resulted in their loss under the reaction conditions required with the propargyl bromide. The 3(prop-2-ynylamino)propan-1-ol was subsequently reacted in a vast excess with the epoxy-activated sepharose 6B matrix to give an unknown yield (scheme 3.5). Traditional chemical identification techniques are not amenable to quantifying the outcome of matrix derivatisations of this sort, therefore a proof of principle using colour was used to identify the product.

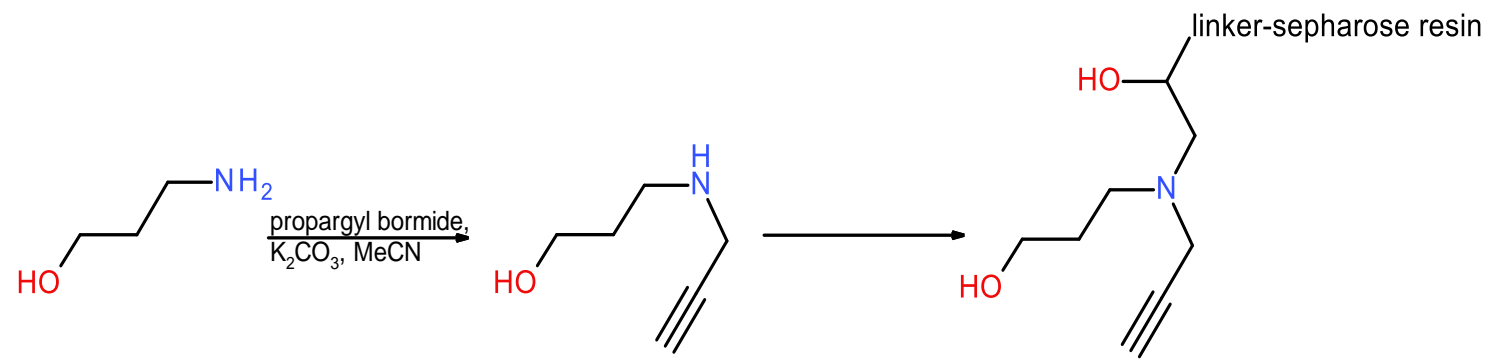

Scheme 3.5. Synthesis of the alkyne-sepharose matrix. 
A fellow chemist in the School of Chemical and Physical Sciences (Victoria University of Wellington) has been working on azulene derived compounds that are densely coloured even at nanomolar concentrations (Bevan, 2010). Given its colour and availability, 6-methylazulene was reacted with p-azidobenzyl bromide. The product 6-[2-(4-azidophenyl)ethyl]azulene was then reacted under Huisgen Cyclisation conditions (Speers \& Cravatt, 2004) in a cell lysate with the alkyne-substituted sepharose 6B matrix. No yield was recordable. However, when compared to a control reaction with the click conditions and underivatised epoxide activated resin, it was clear the p-azidobenzyl azulene substituted the alkyne-substituted matrix, giving a persistent blue colour. As figure 3.13 shows, there is retention of colour on the azulene substituted matrix. Ammonia was used to remove any copper species, by forming tetraamminecopper(II) sulphate, ensuring the only remaining blue colour could come from immobilised azulene. The Huisgen Cyclisation conditions lead to a blue sepharose matrix and without the click conditions a white speharose matrix was present. While these results were only an indication that the matrix was undergoing a Huisgen Cyclisation reaction via the alkyne of the modified matrix, it was believed to be strong enough evidence to proceed. The azulene capture
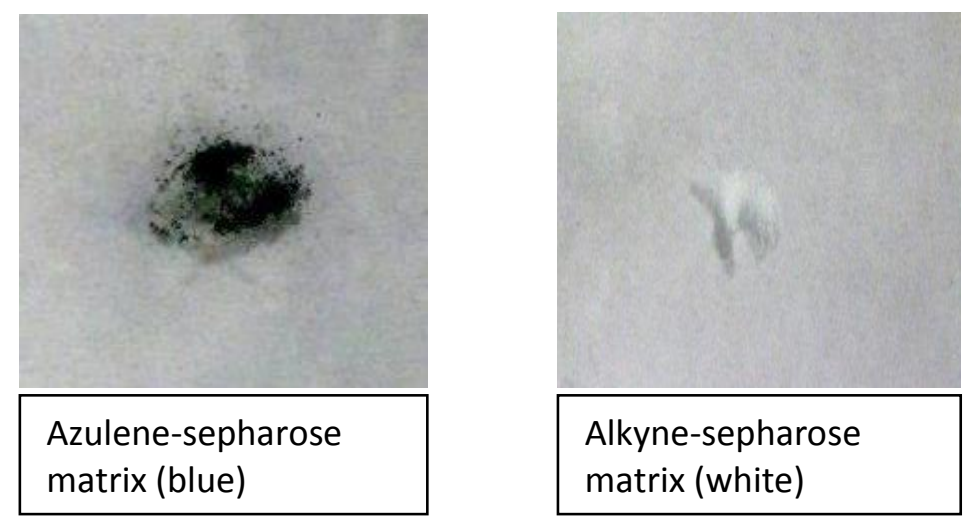

Figure 3.13. Demonstrates visual results for azulene-sepharose matrix compared to the alkyne-sepharose matrix; for proof of principle purposes. Two samples of alkynesepharose matrix was subjected to azulene-azide; one with the Huisgen Cyclisation condition one without, to determine if azulene will "click" to the alkyne matrix. Both the alkyne-sepharose matrices were multiple solvent washes, then to an ammonia wash followed by multiple water washes. The sample treated under the cyclisation conditions lead to a blue matrix, while the other lead to white matrix, indication the reaction was successful. 
from the cell lysate proved the principle, and the approach may be valuable in other cases (ie attempts to identify targets of other bioactive compounds).

Unfortunately, 24 has been shown to have no activity against $\Delta p d r 1 \Delta p d r 3$ (S. cerevisiae). However, pull-down from lysate was attempted as weak binding, metabolic degradation or reduced cell entry could have been the cause of the lack of activity. It could also indicate whether $\mathbf{2 4}$ is binding to proteins that do not lead to cell death. Unfortunately, and in line with the lack of activity, no proteins were selectively isolated using the affinity matrix, which indicates substantial constraints operating with this part of the target's binding pocket. Future work may identify a compound that can utilise the alkyne-modified matrix.

\subsubsection{Chemical genomic screen gives insight to the biological role of benzose}

During this study it was identified that benzose breaks down in agar (section 3.4.6), but through careful preparation of benzose-containing agar plates, the $\Delta p d r l \Delta p d r 3 \Delta x x x$ deletion library was screened identifying 53 resistant and 18 sensitive strains. All sensitive strains were verified in liquid culture, along with 34 of the 53 resistant strains.

Benzose belongs to a class of cyclopropanated carbohydrates which have been shown to have activity against cancer cell lines (Sanhueza et al. 2007). Benzose may bind and inhibit a protein synthesis related protein via one of the proposed mechanisms (section 1.4.2) as indicated by the genomic screen results, and so inhibit growth in $\Delta p d r l \Delta p d r 3$ cells. However, no inhibition was observed in the HL-60 and 1A9 mammalian cell lines or the bacterial strains Psa-V 18800 and E.coli DH5a, suggesting that the role of benzose in inhibition is selective to S. cervisiae. Compound 29 showed no activity in $\Delta p d r 1 \Delta p d r 3$ cells however, literature showed 29 as 
having an $\mathrm{IC}_{50}$ in the low micromolar range against HeLa (Sanhueza et al. 2007).
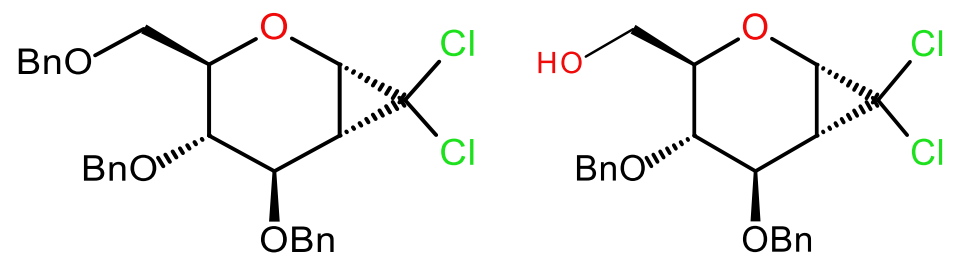

Figure 3.14. Compound 29 and benzose (7)

A number of benzose-resistant deletion mutants were identified in the chemical genetic screen, but failed to show functional enrichment by Gene Ontology (GO) analysis. However, a very high proportion of genes whose deletion lead to resistance encode for proteins involved in ribosomal transcription or translation (CKBI, CTK 1, MED 1, RMD7, RPL19b, PLR43a, RPL43a, RPS14b, RPS1a, RPS6a, RRN10, SNF5, SPT2, SPT21, UBP3, SIP3, IRE 1, ATP11, and RPN4). The deletion of these genes could cause impairment in protein synthesis. Limiting protein synthesis has been identified as a method of increasing cell growth under pressures of toxicity such as an increase in misfolded proteins caused by bioactive compounds (Ding 2007; Steffen et al. 2012).

A previously reported chemical genetic screen using tunicamycin, a known $\mathrm{N}$-linked glycosylation inhibitor in the ER, is often used to prompt the unfolded protein response. Yeast strains with ribosomal protein knockouts treated with tunicamycin have been shown to result in resistance, the associated resistance varied dramatically depending on the corresponding ribosomal protein knock out. Tunicamycin resistance was found to be partially $\mathrm{Hacl}$ independent. $\mathrm{Hac}_{-1} \mathrm{independent} \mathrm{resistance} \mathrm{to}$ ER stress in yeast is thought to activate transcriptional response to ER stress. The stress is reliant on the contact between RNA Pol II and the core promoter of ER chaperone genes (Schroder et al. 2003). Interestingly, a majority of the hits found in the genetic screen identify ribosomal protein 
knock outs, resulting in resistance. Also, RNA Pol II related knockouts were identified as sensitive and resistant, with suppressors as sensitive and up regulators as being resistant.

Wild-type yeast was co-treated with tunicamycin and cycloheximide to determine whether reduced translation generally resulted in tunicamycin resistance, this was found to be true (Steffen et al. 2012). If this holds true as a comparison to benzose, a strain that has a decreased rate of protein synthesis will show resistance. Reducing the rate of protein synthesis will allow the cell to "keep up" with the increased misfolding. To identify whether decreased protein synthesis is causing resistance it would be advisable to co-treat with benzose and a known protein synthesis inhibitor. Recently, benzose was subjected to a protein misfolding assay.

These results suggest that benzose like Tunicamycin may induce the unfolded protein response, to determine this, the UPR assay was conducted.

\subsubsection{The effect of benzose on the unfolded protein response UPRE}

Benzose may have one or more roles in protein synthesis. For example, it may lead to production of misfolded proteins. Misfolded proteins are degraded and recycled to prevent toxic effects (Das et al. 2013; Goldberg, 2003). If benzose is causing an increase in misfolding of proteins, the cell's protein recycling pathways will be unable to keep up with the increased workload. Amongst the sensitive hits were $\Delta$ ire l, $\triangle Y J R 087 \mathrm{~W}$ (overlaps emc2), and $\Delta$ aim27, all of which are associated with protein misfolding, indicating this as a potential function of benzose which will likely trigger the unfolded protein response (UPR) (Rao et al. 2004; Lin et al. 2007; Jonikas et al. 2009). The primary causes of UPR in a cellular context are elevated synthesis of secretory proteins, expression of mutant proteins prone to misfolding, and altered glycosylation (Kaufman, 2002). However, inhibition of proteins essential to protein folding will also lead to upregulation of the UPR system. 
An assay was conducted to assess the ability of benzose to perturb protein folding. The UPR assay uses a strain of yeast in which the expression of a red fluorescent reporter protein (RFP) is controlled by the unfolded protein responsive element (UPRE). An increase in RFP levels acts as an indicator of UPR activation (Jonikas et al. 2009; Bernales et al. 2006; Okamuraa et al. 2000). Unfortunately, this UPR assay strain does not have the $\Delta p d r l \Delta p d r 3$ background, and so it was recognised that the efficient efflux of benzose that ablates growth inhibition in the presence of a functioning PDR system could also lead to a negative response in this UPR assay system. Whilst a positive result in the assay would have confirmed an effect on protein folding, unfortunately the negative result obtained in this assay is not informative. Work is ongoing to place the UPR reporter construct into the $\Delta p d r l \Delta p d r 3$ background.

The primary causes of UPR in a cellular context are elevated synthesis of secretory proteins, expression of mutant proteins prone to misfolding, and altered glycosylation (Kaufman, 2002). In this experiment, benzose did not produce a response from the UPR GFP reporter expression.

\subsubsection{Deletion mutants sensitive to benzose}

The 18 benzose hypersensitive strains were subjected to the same analysis as the resistant strains. However, eight of these strains have been previously identified as multidrug sensitising (Hillemeyer et al. 2008). The term multidrug sensitising is given to a gene deletion that leads to sensitivity to multiple drugs of diverse structure and activity. For example, a gene that encodes for a protein involved in cell wall synthesis, when removed may allow for a higher concentration of drug to diffuse into the cell, making the cell more susceptible to cell death (Hillemeyer et al. 2008; Parsons et al. 2004; Parsons et al. 2006). Of the 10 genes that are not multidrug sensitising, three were found to be involved in RNA localisation, one in the negative regulation of transcription from RNA polymerase ॥ promoter in response to stress and three were found to be involved in the 
negative regulation of cellular protein biosynthesis. Therefore, as observed with the resistant genes, the majority of sensitive genes are found to be involved in transcription and/or translation.

There were no statistically significant enriched processes relating to these sensitive strains, although removing multiple hypothesis test corrections (such as the Bonferroni correction), results in the phospholipid biosynthesis pathway being noted as enriched, albeit on the basis of only two strains (CHO2 \& OPI3). Interestingly, IRE1, $\mathrm{CHO} 2$ and OPI3 genes result in a Yeastmine (www.yeastmine.org) publication enrichment for an article "The membrane stress response buffers lethal effects in disequilibrium by reprogramming the protein homeostasis" (Thibault et al. 2012).

\subsubsection{Mutants effected by benzose}

Fifteen of the gene deletion strains identified as either benzose sensitive or resistant encode ribosomal subunits or proteins involved in the regulation of protein synthesis, five of which were directly associated with RNApolymerase I and II. The yeast ribosome consists of 78 ribosomal proteins, encoded by 137 genes, two per ribosomal protein. Twenty of the 30 most abundant mRNAs encode ribosome proteins. The mRNAs from these genes have significantly shorter half-lives compared to other mRNAs, and an estimated $50 \%$ of the RNA-polymerase-II-mediated transcription events involve ribosomal proteins (Warner, 1999). S. cerevisiae utilises transcription as its primary means of regulating ribosomal synthesis, whereas eubacteria utilise translation, albeit in very different ways.

To date benzose has only been found to be active in S. cerevisiae. It can therefore be suggested that benzose may have an effect on a step in translation or subsequent processing of, for example, a ribosomal subunit; however the exact biological mechanism through which benzose acts remains open for further investigation. 


\subsection{Overall discussion}

Over the course of this study benzose has been developed as the most potent glycal inhibitor of growth in the S. cerevisiae strain $\Delta p d r l \Delta p d r 3$, from the library synthesised. The genomic assay suggests a role within transcription and/or translation. It is currently believed benzose has a direct or indirect role on ribosomal proteins. Selective covalent binding may have occurred, this remains to be investigated, and there are many questions still to be answered.

\subsection{Assessment of experimental strategies and protocols}

The overall strategies and protocols described in this thesis were designed to identify a lead compound and its biological mode of action in a rational manner. The SAR analysis allowed the bioactive compounds to be identified and a lead found. However, a larger library of glucosides needs to be tested to add more scope to the study.

The chemical genomic screen using benzose was able to identify some likely pathways and processes that are being affected. The major problem found here was the breakdown of benzose and the associated activity reduction of benzose in agar. This could be repeated in liquid culture to determine if the lack of reactivity limited the genetic screen. The 1536format agar-based high throughput is efficient from the perspective of compound use, practical simplicity and internal replication. The amount of benzose required for a liquid-based high throughput screen would not act as a deterrent, as benzose is synthesised in four steps from D-glucal.

A limitation in the chemical proteomics was found to be the lack of activity of 24. Attaching a probe to benzose on the C-6 hydroxyl of benzose would most likely lead to loss of activity, as evident in the SAR analysis which showed that the formate ester exterminated all activity against the $\Delta p d r l \Delta p d r 3$ strain. Further investigations are required to 
identify a method of attaching a biological probe to benzose in order to identify the target, without the loss of activity.

Within the chemistry section of this thesis it was determined that the synthesis of each compound was achieved in the fewest steps currently known. Methods of dihalocyclopropanation without the need for a fully protected glucal would lead to a much easier synthesis of further compounds destined to join the SAR. A method of dichlorocyclopropanation of an alkene via a dichlorocarbene, magnesium and ultrasonication, had been previously presented by Lin et al. (2003). Scheme 3.6 demonstrates this reaction on 3,4-dihydro-2H-pyran resulting in the 7,7-dichloro-5-oxabicyclo[4.1.0]heptane, in an impressive yield of $95 \%$. This high yield would reflect the lack of competing functionality in this system, no compounds with C-3 functionality have been described at present in the literature. However, it would be worth invesitagating this cyclopropanation method on D-glucal. This method may offer a way of synthesising novel dichlorocyclopropanated carbohydrates.
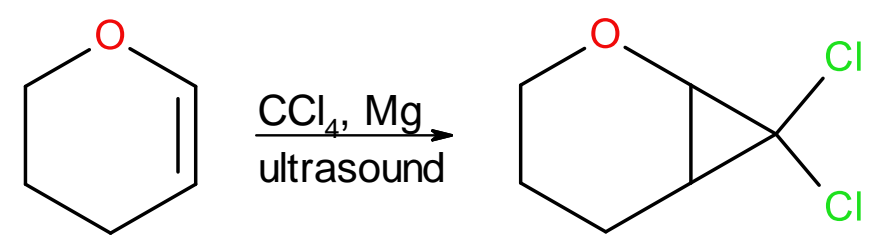

Scheme 3.6. Synthesis of 7,7-dichloro-5-oxabicyclo[4.1.0] heptane via a dichlorocarbene, magnesium and ultra-sonication with a yield of $95 \%$. 


\subsection{Assessment of the aims and objectives}

The overall aim of this project was to determine whether cyclopropanated sugars that can undergo ring opening or ring expansion reactions have ideal characteristics for suicide inhibitors. In this respect, it was partially successful. Of the four objectives set out in this thesis, three were achieved.

Objective one was to design and synthesise a range of compounds that would allow identification of bioactivity, and to give an idea of the mechanism of action. A range of compounds were synthesised consisting of cyclopropanated carbohydrates and their glucal precursors.

With a range of compounds synthesised, objective 2 was to identify a lead compound, which was benzose. The library allowed identification of the most likely chemical mechanism through which the compound might covalently modify a target protein. If covalent modification occurs, it is proposed to go via a stabilised carbanion. Again the objective was met, the lead compound was then subjected to a chemical genetic screen.

Objective three consisted of trying to identify the likely mode of action of the selected lead compound within the biological environment. This objective was completed with benzose, which was found to be both cytostatic and cytotoxic depending on concentration. It appears to interact specifically with translation and transcription pathways.

The final objective was to identify the likely protein target(s) of the lead compound. A modified matrix and a benzose-like compound $\mathbf{2 4}$ were synthesised to achieve this target. However, compound $\mathbf{2 4}$ was found to be inactive, which raises the questions of the ability to use a chemical proteomic approach for these compounds. With the lack of time, objective four has yet to be accomplished. 


\subsection{Future directions}

A considerable amount of progress has been made towards the application of mechanism-based inhibitors, consisting of a cyclopropane on a carbohydrate backbone. While many structures have been synthesised, many more could be made for further investigations. Identification of the biological target would be a major step forward in presenting the "big picture" in which benzose has its effect.

\subsection{SAR where to now?}

The development of a range of cyclopropanated derivatives has yielded a varying degree of activity, however there is a large area of stereochemistry yet to be investigated. Allose and galactose offer differing stereochemical arrangements compared to glucose, and would offer a good starting point to extend the structure activity relationship. The substituents on the C-3 and C-4 hydroxyls also offer an area that warrant more investigation. As discussed in section 3.5.2, the most likely mechanism of action is through the carbanion intermediate, although this remains to

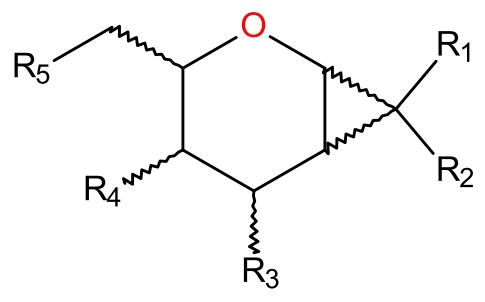

Figure 5.1. A cyclopropanated carbohydrate showing all possible stereo isomers, showing the use of multiple 6-carbon sugars.

$\mathrm{R}_{1}, \mathrm{R}_{2}=\mathrm{Cl}, \mathrm{Br}, \mathrm{I}, \mathrm{H}, \mathrm{NHR}, \mathrm{CONH}_{2}, \mathrm{CONHR}$,

$\mathrm{R}_{3}=\mathrm{OH}, \mathrm{OBn}, \mathrm{OBz}, \mathrm{Me}, \mathrm{Ac}$, alkyl chain, NHR,

$\mathrm{R}_{4}=\mathrm{OH}, \mathrm{OBn}, \mathrm{OBz}, \mathrm{OMe}, \mathrm{OAc}$, alkyl chain, NHR,

$\mathrm{R}_{5}=\mathrm{OH}, \mathrm{OBn}, \mathrm{OBz}, \mathrm{OMe}, \mathrm{OAc}$, alkyl chain, NHR, 
be proven. The research into benzose has proposed two methods of moving forward with the SAR studies. Firstly, ignore the protein target and make more cyclopropanated carbohydrates (figure 5.1) to try and increase the toxicity on the whole cell, or secondly focus on identifying the biological target and design potent, benzose-like compounds for this target.

Benzose its self may never offer a biologically relevant compound, however the ring breaking mechanism offers a novel mechanism-based inhibition that warrants more research. The use of the cyclopropane with the carbohydrate backbone has been shown to be active, most likely through the ring breaking mechanism, which answers the question "Will cyclopropanated carbohydrates undergo the slow ring breaking/expansion in the presence of proteins, and are we able to identify what of three types of mechanisms the reaction is going through?" The question can now be changed to further identify key aspects of activity, "will modifications to the structure provide selective binding to a biologically relevant target?" 


\subsection{Conclusion}

We set out to identify the potential in drug discovery of known and novel cyclopropanated-carbohydrates. With the background knowledge of known chemistry that is well precedented in the literature, we proposed that this known chemistry could be catalysed by a selective protein.

Over the course of this project, a library of cyclopropanated carbohydrate based compounds has been synthesised, with regio- and stereoselective chemistry in mind. Five compounds (all cyclopropanecontaining) were found to display cytotoxic activity against $S$. cerevisiae ( $\Delta p d r 1 \Delta p d r 3$ ), with the most active being benzose. A derivative of benzose was then synthesised to act as a molecular probe to give a tool to identify the protein target. However, this compound lacked activity and failed to pull down any proteins for identification. The current mechanism through which benzose acts in S. cerevisiae is unknown, but it is believe to be involved in transcription or translation, potentially via a ribosomal target, further investigations are needed. 


\subsection{References}

Alonso, R. A., \& Rossi, R. A. (1980). SRN1 mechanism in bifunctional systems. Journal of Organic Chemistry, 45(23), 4760-4763.

Andrade, M. A., Sander, C., \& Valencia, A. (1998). Updated catalogue of homologues to human disease-related proteins in the yeast genome. Federation of European Biochemical Societies, 426(1), 7-16.

Arnoldo, A., Curak, J., Kittanakom, S., et al. (2008). Identification of small molecule inhibitors of Pseudomonas aeruginosa exoenzyme $S$ using a yeast phenotypic screen.PLoS genetics, 4 (2), e1000005.

Baeyer, A. (1885). Über polyacetylenverbindungen. Berichte der Deutschen Chemischen Gesellschaft zu Berlin, 18(2), 2269.

Balani, S. K., Miwa, G. T., \& Gan, L. S., et al. (2005). Strategy of utilizing in vitro and in vivo ADME tools for lead optimization and drug candidate selection. Current topics in Medicinal Chemistry, 5(1 1), 1033-1038.

Bantscheff, M., Lemeer, S., Savitski, M. M., et al. (2012). Quantitative mass spectrometry in proteomics: critical review update from 2007 to the present. Analytical and Bioanalytical Chemistry, 404(4), 939-965.

Bartoli, G., \& Todesco, P. E. (1977). Nucleophilic substitution. Linear free energy relations between reactivity and physical properties of leaving groups and substrates. Accounts of Chemical Research, 10(4), 125-132.

Baumert, C., Günthel, M., Krawczyk, S., et al. (2013). Development of smallmolecule P-gp inhibitors of the n-benzyl 1,4-dihydropyridine type: Novel aspects in SAR and bioanalytical evaluation of multidrug resistance (MDR) reversal properties. Bioorganic \& Medicinal Chemistry, 21 (1), 166-177.

Bernales, S., McDonald, K. L., \& Walter, P. (2006). Autophagy counterbalances endoplasmic reticulum expansion during the unfolded protein response. PLOS Biology, 4(12), 423.

Bickelhaupt, F. M., Hermann, H. L., \& Boche, G. (2006). Alpha-Stabilization of Carbanions: Fluorine is more effective than the heavier halogens. Angewandte Chemie International Edition, 45(5), 823-826.

Blanks, R., \& McLaughlin, L. W. (1988). An oligodeoxynucleotide affinity column for the isolation of sequence specific DNA binding proteins. Nucleic Acids Research, 16(21), 10283-10299.

Blomberg, M. R. A., Siegbahm, P. E. M., \& Baeckvall, J. E. (1987). Theoretical study of the cyclopropane ring opening by palladium (II) complexes. Journal of American Chemical Society, 109(15), 4450-4456.

Boone, C., Bussey, H., \& Andrews, B. J. (2007). Exploring genetic interactions and networks with yeast. Nature Reviews: Genetics, 8(6), 437449. 
Bork, P., Jensen, L. J., von Mering, C., et al. (2004). Protein interaction networks from yeast to human. Current Opinion in Structural Biology, 14(3), 292-299.

Borthwick, A. D., Weingarten, G., Haley, T. M., et al. (1998). Design and synthesis of monocyclic $\beta$-lactams as mechanism-based inhibitors of human cytomegalovirus protease. Bioorganic \& Medicinal Chemistry Letters, 8(4), 365-370.

Botstein, D., Chervitz, S. A., \& Cherry, M. (1997). Yeast as a model organism. Science, 277(5339), 1259-1260.

Brinkman, E. A., Berger, S., \& Brauman, J. I. (1994). Alpha-Silyl-substituent stabilization of carbanions and silyl anions. Journal of the American Chemical Society, 116(18), 8304-8310.

Cameron, D., Casey, M., Press, M., et al. (2008). A phase III randomized comparison of lapatinib plus capecitabine versus capecitabine alone in women with advanced breast cancer that has progressed on Trastuzumab: updated efficacy and biomarker analyses. Breast Cancer Research and Treatment, $112(3), 533-543$.

Carotti, A., Carrieri, A., Chimichi, S., et al. (2002). Natural and synthetic geiparvarins are strong and selective MAO-b inhibitors. Synthesis and SAR studies. Bioorganic \& Medicinal Chemistry Letters, 12 (24), 3551-3555.

Cho, Y. S., \& Kwon, H. J. (2012). Identification and validation of bioactive small molecule target through phenotypic screening. Bioorganic \& Medicinal Chemistry, 20(6), 1922-1928.

Chu-Moyer, M.Y., \& Danishefsky, S. J. (1993). On the mode of action of myrocin C: evidence for a CC-1065 connection. Tetrahedron Letters, 34(19), 3025-3028.

Costantino, L., \& Barlocco, D. (2006). Privileged structures as leads in medicinal chemistry. Current medicinal chemistry, 13(1), 65-85.

Cousins, G. S., \& Hoberg, J. O. (2000). Synthesis and chemistry of cyclopropanated carbohydrates. Chemical Society Review, 29(3), 165-174

Crum-Brown, A., \& Fraser, T. R. (1868). V.- -on the connection between chemical constitution and physiological action. Part. I.- on the physiological action of the salts of the ammonium bases, derived from strychnia, brucia, thebaia, codeia, morphia, and nicotia. Transactions of the Royal Society of Edinburgh, 25(1), 151-203.

Cuatrecasas, P. (1970). Protein purification by affinity chromatography derivatizations of agarose and polyacrylamide beads. The Journal of Biological Chemistry, 245(12), 3059-3065. 
Das, I., Png, C. W., Oancea, I., et al. (2013). Glucocorticoids alleviate intestinal ER stress by enhancing protein folding and degradation of misfolded proteins. Journal of Experimental medicine, 210(6), 1201-1216.

Ding, W. X., Ni, H. M., Gao, W., et al. (2007). Differential effects of endoplasmic reticulum stress-induced autophagy on cell survival. Journal of Biological Chemistry, 282(7), 4702-4710.

Dombernowsky, P., Smith, I., Falkson, G., et al. (1998). Letrozole, a new oral aromatase inhibitor for advanced breast cancer: double-blind randomized trial showing a dose effect and improved efficacy and tolerability compared with megestrol acetate. Journal of Clinical Oncology, 16(2), 453-461.

Dumont, P., Ingrassia, L., Rouszeau S., et al. (2007). The amaryllidaceae isocarbostyril narciclasine induces apoptosis by activation of the death receptor and/or mitochondrial pathways in cancer cells but not in normal fibroblasts. Neoplasia, 9(9), 766-776.

Esswein, A., Rembold, H., \& Schmidt, R. R. (1990). O-alkylation at the anomeric centre for the stereoselective synthesis of Kdo-a-glycosides. Carbohydrate Research, 200, 287-305.

Ferrari, E., Lucca, C., \& Foiani, M. (2010). A lethal combination for cancer cells: Synthetic lethality screenings for drug discovery. European Journal of Cancer, 46(16), 2889-2895.

Firestine, S. M., Paritala, H., Mcdonnell, J. E., et al. (2009). Identification of inhibitors of $\mathrm{N}$-5-carboxylaminoimidoazole ribonucleotide synthetase by high-throughput screening. Bio-organic Medicinal chemistry, 17(9), 33173323.

Fischer, E., \& Zach, K. (1912). Uber neve anhydride der glucose und glucoside. Berichte der deutschen chemischen gesellschaft, 45(1), 456465.

Frank, J. Jr., van Krimpen, S. H., Verwiel, P. E., et al. (1989). On the mechanism of inhibition of methanol dehydrogenase by cyclopropanederived inhibitors. European Journal of Biochemistry, 184(1), 187-195.

Freund, A. (1881). Über die bildung und darstellung von trimethylenalkohol aus glycerin. Monatshefte für Chemie, 2(1), 636-641.

Friedman, S. H., DeCamp, D. L., Sijbesma, R. P., et al. (1993). Inhibition of the HIV-1 protease by fullerene derivatives: model building studies and experimental verification. Journal of the American Chemical Society, 115(15), 6506-6509.

Gammon, D. W., Kinfe, H. H., De Vos, D. E., et al. (2007). A new procedure for highly regio- and stereoselective iodoacetoxylation of protected glycals and a-1,2-cyclopropanated sugars. Journal of Carbohydrate Chemistry, 26(3), 141-157. 
Ganesh, N. V., \& Jayaraman N. (2009). Synthesis of aryl, glycosyl, and azido septanosides through ring expansion of 1,2-cyclopropanated sugars. The Journal of Organic Chemistry, 74(2), 739-746.

Ganesh, N. V., \& Jayaraman, N. (2007). Synthesis of septanosides through an oxyglycal route. The Journal of Organic Chemistry, 72 (15), 5500-5504.

Geoffeau, A., Barrell, B. G., Bussey, H., et al. (1996). Life with 6000 Genes. Science, 274, 563-567.

Goldberg, A. L. (2003). Protein degradation and protection against misfolded or damaged proteins. Nature, 426(6968), 895-899.

Gubbens, J., Ruijter, E., de Fays, L. E., et al. (2009). Photocrosslinking and click chemistry enable the specific detection of proteins interacting with phospholipids at the membrane interface. Chemistry \& Biology, 16(1), 3-14.

Haddow, J., Suckling, C. J., \& Wood, H. C. (1987). Latent inhibition of dihydrofolate reductase by a spirocyclopropyl pteridine. Journal of the Chemical Society, Chemical Communications, Perkin Transactions 1, 6(1), 478-480.

Hamann, C. H., Pleus, S., Koch, R., et al. (1999). Semiempirical study on the substitution mechanism of carbohydrates. Journal of Carbohydrate Chemistry, 18(9), 1051-1065.

Hanzlik, R. P., Kishore, V., \& Tullman, R. (1979). Cyclopropylamines as suicide substrates for cytochromes p-450. Journal of Medicinal Chemistry, 22(7), 759-761.

Hewitt, R. (2008). Ring Expansions of Cyclopropanated Carbohydrates. Victoria University of Wellington: PhD Thesis.

Hewitt, R. J., \& Harvey, J. E. (2010). Synthesis of oxepines and 2-branched pyranosides from a-glucal-derived-dibromo-1,2-cyclopropanated sugar. Journal of Organic Chemistry, 75(3), 955-958.

Hillenmeyer, M. E., Fung, E., Wildenhain, J., et al. (2008). The Chemical Genomic Portrait of Yeast: Uncovering a Phenotype for All Genes. Science 320(5874), 362-365.

Hoberg, J. O., \& Bozell, J. J. (1995). Cyclopropanation and ring expansion of unsaturated sugars. Tetrahedron Letters, 36(38), 6831-6834.

Huang, J., Zhu, H., Haggarty, S. J., et al. (2004). Finding new components of the target of rapamycin (TOR) signaling network through chemical genetics and proteome chips.Proceedings of the National Academy of Sciences of the United States of America, 101 (47), 16594-16599.Huisgen, R., Mloston, G., \& Langhals, E. (1986). The first two-step 1, 3-dipolar cycloadditions: interception of intermediate. The Journal of Organic Chemistry, 51 (21), 4085-4087. 
James, P., Halladay, J., \& Craig, E. A. (1996). Genomic libraries and a host strain designed for highly efficient two-hybrid selection in yeast. Genetics, 144(4), 1425-1436.

Jeffery, D. A., \& Bogyo, M. (2003). Chemical proteomics and its application to drug discovery. Current Opinion in Biotechnology, 14(1), 87-95.

Johnson, E. S. (2004). Protein modification by SUMO. Annual Review of Biochemistry, 73(1), 355-382.

Jonikas, M. C., Collins, S. R., Denic, V., et al. (2009). Comprehensive characterization of genes required for protein folding in the endoplasmic reticulum. Science Signalling, 323(5922), 1693-1697.

Joyce, A. R., \& Palsson, B. $\underline{\varnothing}$. (2006). The model organism as a system integrating 'omics' data sets. Nature Reviews: Molecular cell Biology, 7(3), 198-210.

Jungwirth, H., \& Kuchler, K. (2006). Yeast ABC transporters- a tale of sex, stress, drugs and aging. Federation of European Biochemical Societies Letters, 580(4), 1131-1138.

Kataoka, T., Powers, S., Cameron, S., et al. (1985). Functional homology of mammalian and yeast RAS genes. Cell, 40(1), 19-26.

Kaufman, R. J. (2002). Orchestrating the unfolded protein response in health and disease. Journal of Clinical Investigation, $110(10), 1389-1398$.

Klevens, R. M., Morrison, M. A., Nadle, J., et al. (2007). Invasive methicillinresistant Staphylococcus aureus infections in the United States. The Journal of the American Medical Association, 298(15), 1763-1771.

Kloss, F., Köhn, U., Jahn, B. O., et al. (2011). Metal-free 1, 5-regioselective azide-alkyne [3 2]-cycloaddition. Chemistry an Asian Journal, 6(10), 28162824.

Kolb, H. C., \& Sharpless, K. B. (2003). The growing impact of click chemistry on drug discovery. Drug Discovery Today, 8(24), 1128-1137.

Kramer, R., \& Cohen, D. (2004). Functional genomics to new drug targets. Nature reviews: Drug discovery, 3(11), 965-972.

Labischinski, H. (1992). Consequences of the interaction of $\beta$-lactam antibiotics with penicillin binding proteins from sensitive and resistant Staphylococcus aureus strains. Medical Microbiology and Immunology, $181(5), 241-265$.

Leeson, P. D., \& Springthorpe, B. (2007). The influence of drug-like concepts on decision-making in medicinal chemistry. Nature Reviews: Drug Discovery, 6(11), 881-890. 
Leslie, B. J., \& Hergenrother, P. J. (2008). Identification of the cellular targets of bioactive small organic molecules using affinity reagents. Chemical Society Reviews, 37 (7), 1347-1360.

Lin, H., Yang, M., \& Huang, P. (2003). A facile procedure for the generation of dichlorocarbene from the reaction of carbon tetrachloride and magnesium using ultrasonic irradiation. Molecules, 8(8), 608-613.

Lin, J. H., Li, H., Yasumura, D., et al. (2007). IREl signaling affects cell fate during the unfolded protein response. Science Signaling, 318(5852), 944949.

Liu, J. Q., Kurihara, T., Miyagi, M., et al. (1995). Reaction mechanism of L-2Haloacid dehalogenase of Pseudomonas sp. YL identification of Asp as the active site nucleophile by ${ }^{18} \mathrm{O}$ incorporation experiments. Journal of Biological Chemistry, 270(31), 18309-18312.

Lizawa, Y., Nagai, J., \& Ishikawa, T., et al. (2004). In vitro antimicrobial activity of T-91825, a novel anti-MRSA cephalosporin, and in vivo antiMRSA activity of its prodrug, Tak-599. Journal of Infection and Chemotherapy: Official Journal of the Japan Society of Chemotherapy, 10(3), 146-156.

Lokey, R. S. (2003). Forward chemical genetics: progress and obstacles on the path to a new pharmacopoeia. Current Opinion in Chemical Biology, 7(1), 91-96.

Makosza, M., \& Wawrsyniewicz, M. (1969). Reactions of organic anions. xxiv. Catalytic method for preparation of dichlorocyclopropane derivatives in aqueous medium. Tetrahedron Letters, 10(53), 5659-4662.

Marik, R., Allu, M., Anchoori, R., et al. (2011). Potent genistein derivatives as inhibitors of estrogen receptor alpha-positive breast cancer. Cancer Biology \& Therapy, 11 (10), 883-892.

McCaul, S., \& Byers, L. D. (1976). The reaction of epoxides with yeast glyceraldehyde-3-phosphate dehydrogenase. Biochemical and Biophysical Research Communications, 72(3), 1028-1034.

Meijere, A. D. (1979). Bonding properties of cyclopropane and their chemical consequences. Angewandte Chemie, 18(11), 809-826.

Meijere, A. D. (2003). Introduction: cyclopropanes and related rings. Chemical review, 103(4), 931-932.

Meldgaard, M., \& Wengel, J. (2000). Bicyclic nucleosides and conformational restriction of oligonucleotides. Journal of the Chemical Society, Perkin Transactions 1, 21 (1), 3539-3554.

Mereyala, H. B., \& Kulkarni, V. R. (1989). Regioselectivity in the reactivity dibutylstannylene derivatives of glycals. Carbohydrate Research, 187(1), 154-158. 
Mornet, R., Leonard, N. J., Theiler, J. B., et al. (1984). Specificity of the 1methyladenine receptors in starfish oocytes: synthesis and properties of some 1,8-disubstituted adenines, 1,6-dimethyl-1h-purine and of the 1(azidobenzyl) adenines. Journal of the Chemical Society, Perkin Transactions 1, 1(0) 879-885.

Moses, J. E., \& Moorhouse, A. D. (2007). The growing applications of click chemistry. Chemical Society Reviews, 36(8), 1249-1262.

Murali, C., Shashidhar, M. S., \& Gopinath, C. S. (2007). Hydroxyl group deprotection reactions with $\mathrm{Pd}(\mathrm{OH})_{2} / \mathrm{C}$ : a convenient alternative to hydrogenolysis of benzyl ethers and acid hydrolysis of ketals. Tetrahedron, 63(19), 4149-4155.

Nagarajan, M., Murali, R., \& Ramana, C. V. (1997). Synthesis and reactions of 1,2-cyclopropanted sugars. Journal of Organic Chemistry, 62 (22), 76947703.

Neidell, M. J., Cohen, B., Furuya, Y., et al. (2012). Cost of healthcare- and community-associated infections with antimicrobial resistant versus antimicrobial-susceptible organisms. Clinical infectious diseases, 55(6), 807815.

Neurath, H., \& Walsh, K. A. (1976). Role of proteolytic enzymes in biological regulation (a review). Proceedings of the National Academy of Sciences of the United States of America, 73(11), 3825-3832.

Nourani, A., Wesolowski-Louvel, M., Delaveau, T., et al. (1997). Multipledrug-resistance phenomenon in the yeast saccharomyces cerevisiae: Involvement of two hexose transporters. Molecular and Cellular Biology, 17(9), 5453-5460.

Okamura, H., Aramburu, J., García-Rodríguez, C., et al. (2000). Concerted dephosphorylation of the transcription factor NFATI induces a conformational switch that regulates transcriptional activity. Molecular Cell, 6(3), 539-550.

Onda, M., Ota, K., Chiba, T., et al. (2004). Analysis of gene network regulating yeast multidrug resistance by artificial activation of transcription factors: involvement of Pdr3 in salt tolerance. Gene, 332, 51-59.

Overall, C. M., \& Kleifeld, O. (2006). Towards third generation matrix metalloproteinase inhibitors for cancer therapy. British Journal of Chemistry, 94(7), 941-946.

Paech, C., Salach, J. I., \& Singer, T. P. (1980). Suicide inactivation of monoamine oxidase by trans-phenylcyclopropylamine. Journal of Biological Chemistry, 255(7), 2700-2704.

Parsons, A. B., Brost, R. L., Ding, H., et al. (2003). Integration of chemicalgenetic and genetic interaction data links bioactive compounds to cellular target pathways. Nature biotechnology, 22(1), 62-69. 
Parsons, A. B., Lopez, A., Givoni, I. E., et al. (2006). Exploring the mode-ofaction of bioactive compounds by chemical-genetic profiling in yeast. Cell, 126(3), 611-625.

Patani, G. A., \& LaVoie, E. J. (1996). Bioisosterism: A rational approach in drug design. Chemical Reviews, 96(8), 3147-3176.

Perkin, W. H. (1884). On the magnetic rotary polarisation of compounds in relation to their chemical constitution; with observations on the preparation and relative densities of the bodies examined. Journal of the Chemical Society, Transactions, 45(1), 421.

Prasad, R., \& Goffeau, A. (2012). Yeast ATP-binding cassette transporters conferring multidrug resistance. Annual review of Microbiology, 66 (1), 3963.

Qin, H., Yamagiwa, N., Matsunaga, S., et al. (2007). Bismuth-Catalyzed Direct Substitution of the Hydroxy Group in Alcohols with Sulfonamides, Carbamates, and Carboxamides. Angewandte Chemie, 119(3), 413-417.

Rao, R. V., Ellerby, H. M., \& Bredesen, D. E. (2004). Coupling endoplasmic reticulum stress to the cell death program. Cell Death \& Differentiation, $11(4), 372-380$.

von Rechenberg, M.,, Blake, B. K., Ho, Y. S. J., et al. (2005). Ampicillin/penicillin-binding protein interactions as a model drug target system to optimize affinity pull-down and mass spectrometric strategies for target and pathway identification. Proteomics, 5(7), 1764-1773.

Ricci, G., De Maria, F., Antonini, G., et al. (2005). 7-Nitro-2, 1, 3benzoxadiazole Derivatives, a New Class of Suicide Inhibitors for Glutathione S-Transferases mechanism of action of potential anticancer drugs. Journal of Biological Chemistry, 280(28), 26397-26405.

Richet, C. (1893). On the relationship between the toxicity and the physical properties of substances. Comptes Rendus des Seances Societe de Biologie, 9, 775-776.

Risseeuw, M. D., van den Berg, R. J., Donker-Koopman, W. E., et al. (2009). Synthesis and evaluation of D-gluco-pyranocyclopropyl amines as potential glucosidase inhibitors. Bioorganic \& Medicinal Chemistry Letters, 19(23), 6600-6603.

Robertson, J. G. (2005). Mechanistic basis of enzyme-targeted drugs. Biochemistry, 44(15), 5561-5571.

Rogers, B., Decottignies, A., Kolaczkowski, M. et al. (2001). The pleitropic drug $A B C$ transporters from saccharomyces cerevisiae. Journal of molecular microbiology biotechnology, 3(2), 207-214. 
Rooseboom, M., Commandeur, J. N., \& Vermeulen, N. P. (2004). Enzymecatalysed activation of anticancer prodrugs. Pharmacological reviews, 56(1), 53-102.

Salaün, J. (2000). Cyclopropane derivatives and their diverse biological activities. In Small Ring Compounds in Organic Synthesis VI (pp. 1-67). Springer Berlin Heidelberg.Sander, E. G., McCormick, D. B., \& Wright, L. D. (1966). Column chromatography of nucleotides over thymidylatecellulose. Journal of Chromatography A, 21, 419-423.

Sanhueza, C. A., Mayato, C., Padrón, J. M., et al. (2007). Cytotoxic effects of c-glycosides in HOS and HELa cell lines. Bioorganic \& Medicinal Chemistry Letters, 17(13), 3676-3681.

Schwendener, R. A., \& Schott, H. (2010). Liposome formulations of hydrophobic drugs. Methods in Molecular Biology, 605(1), 129-138.

Semenza, G. L. (2002). HIF-1 and tumor progression: pathophysiology and therapeutics. Trends in molecular medicine, 8(4), S62-\$67.

Setty, S. R., Strochlic T. I., Tong, A. H., et al. (2004). Golgi targeting of ARFlike GTPase Arl3p requires its Na-acetylation and the integral membrane protein Sys 1p. Nature Cell Biology, 6(5), 414-419.

Shah, N. P., Tran, C., Lee, F. Y., et al. (2004). Overriding imatinib resistance with a novel ABL kinase inhibitor. Science, 305(5682), 399-401.

Silman, I., \& Katchalski, E. (1966). Water-insoluble derivatives of enzymes, antigens, and antibodies. Annual Review of Biochemistry, 35(1), 873-908.

Silverman, R. B., \& Hoffman, S. J. (1980). Mechanism of inactivation of mitochondrial monoamine oxidase by $\mathrm{N}$-cyclopropyl-N-arylalkyl amines. Journal of American Chemistry Society, 102(2), 884-886.

Silverman, R. B. (1988). Mechanism-based enzyme inactivation: chemistry and enzymology (Vol. 1, p. 135). Boca Raton, FL: CRC press. Simmons, H. E., \& Smith, R. D. (1959). A new synthesis of cyclopropanes. Journal of the American Chemical Society, 81 (16), 4256-4264.

Skulnick, H. I., Johnson, P. D., Howe, W. J., et al. (1995). Structure-based design of sulfonamide-substituted non-peptidic HIV protease inhibitors. Journal of Medicinal chemistry, 38(26), 4968-4971.

Slamon, D. J., Clark, G. M., Wong, S. G., et al. (1987). Human breast cancer: correlation of relapse and survival with amplification of the HER2/NEU oncogene. Science, 235(4785), 177-182.

Slamon, D. J., Godolphin, W., Jones, L. A., et al. (1989). Studies of the HER$2 /$ NEU proto-oncogene in human breast and ovarian cancer. Science, 244(4905), 707-712. 
Sleno, L., \& Emili, A. (2008). Proteomic methods for drug target discovery. Current Opinion in Chemical biology, 12(1), 46-54.

Smith, A. W., (2005). Biofilms and antibiotic therapy: Is there a role for combating bacterial resistance by the use of novel drug delivery systems? Advanced Drug Delivery Reviews, 57(10), 1539-1550.

Smith, C. J., Smith, C. D., Nikbin, N., et al. (2011). Flow synthesis of organic azides and the multistep synthesis of imines and amines using a new monlithic triphenylphosphine reagent. Organic Biomolecular chemistry, 9(6), 1927-1937.

Speers, A. E., \& Cravatt, B. F. (2004). Profiling enzyme activities in vivo using click methods. Chemistry and Biology, 11 (4), 535-546.

Stadtman, E. R. (1990). Covalent modification reactions are marking steps in protein turnover. Biochemistry, 29(27), 6323-6331.

Suckling, C. J. (1988). The cyclopropyl group in studies of enzyme mechanism and inhibition. Angewandte Chemie International edition in English, 27(4), 537-552.

Suter, B., Auerbach, D., \& Stagljar, I. (2006). Yeast-based functional genomics and proteomics technologies: the first 15 years and beyond. BioTechniques, 40(5), 625-644.

Swern, D., \& Omura, K. (1978). Oxidation of alcohols by "activated" dimethyl sulfoxide. A preparative, steric and mechanistic study. Tetrahedron, 34(11), 1651-1660.

Szostak, J. W, Batel, D. P, \& Luisi, L. P. (2001). Synthesizing life. Nature, 409(6818), 387-390.

Talibi, D., \& Raymond, M. (1999). Isolation of a Putative Candida albicans Transcriptional Regulator Involved in Pleiotropic Drug Resistance by Functional Complementation of a pdr1 pdr3 Mutation in Saccharomyces cerevisiae. Journal of bacteriology, 181 (1), 231-240.

Thibault, G., Shui, G., Kim, W., et al. (2012). The membrane stress response buffers lethal effects of lipid disequilibrium by reprogramming the protein homeostasis network. Molecular Cell, 48(1), 16-27.

Thoden, J. B., Holden, H. M., \& Firestine, S. M. (2008). Structural analysis of the active site geometry of $\mathrm{N}$-5-carboxyaminoimidazole ribonucleotide from Escherichia coli. Biochemistry, 47(50), 13346-13353.

Todoroki, Y., Nakano, S. I., Hirai, N., et al. (1996). Ring conformational requirement for biological activity of abscisic acid probed by the cyclopropane analogues. Tetrahedron, 52(24), 8081-8098.

Tong, A. H. Y., Lesage, G., \& Bader, G. D., et al. (2004). Global mapping of the yeast genetic interaction network. Science, 303(5659), 808-813. 
Van Bambeke, F., Mingeot-Leclercq, M. P.,, \& Struelens, M. J., et al. (2008). The bacterial envelope as a target for novel anti-MRSA antibiotics. Trends in Pharmacological Sciences, $29(3), 124-134$.

Van Goietsenoven, G., Hutton, J., Becker, J. P., et al. (2010). Targeting of eEF1A with Amaryllidaceae isocarbostyrils as a strategy to combat melanomas. The Federation of American Societies for Experimental Biology Journal, 24(11), 4575-4584.

Vogel, C. L., Cobleigh, M. A., Tripathy, D., et al. (2002). Efficacy and safety of Trastuzumab as a single agent in first-line treatment of Her2overexpressing metastatic breast cancer. American Society of Clinical Oncology, 20(3), 719-726.

Walsh, C. (1982). Suicide substrates: Mechanism-based enzyme inactivators. Tetrahedron, 38(7), 871-909.

Wang, Y., Hu, S., \& Fast, W. (2009). A click chemistry mediated in vivo activity probe for dimethylarginine dimethylaminohydrolase. Journal of American Chemical Society, 131 (42), 15096-15097.

Warner, J. R. (1999). The economics of ribosome biosynthesis in yeast. Trends in biochemical sciences, 24(11), 437-440.Waters, R. M. \& Schmidt, E. R. (1934). Cyclopropane anaesthesia. The journal of the America Medical Association, 103(13), 975-983.

Way, J. C. (2000). Covalent modification as a strategy to block proteinprotein interactions with small-molecule drugs. Current Opinion in Chemical Biology, 4(1), 40-46.

Wendler, F., Bergler, H., Prutej, K., et al. (1997). Diazaborine resistance in the yeast saccharomyces cerevisiae reveals a link between yapl and the pleiotropic drug resistance genes PDR 1 and PDR3. Journal of Biological Chemistry, 727 (43), 27091-27098.

Wessjohann, L., Brandt, W., \& Thiemann, T. (2003). Biosynthesis and metabolism of cyclopropane rings in natural compounds. Chemistry Reviews, 103(4), 1625-1648.

Wiseman, J. S., \& Abeles, R. H. (1979). Mechanism of inhibition of aldehyde dehydrogenase by cyclopropanone hydrate and the mushroom toxin coprinet. Biochemistry, 18(3), 427-435.

Wolber, G., Seidel, T., Bendix, F., et al. (2008). Molecule-pharmacophore superpositioning and pattern matching in computational drug design. Drug discovery today, 13(1), 23-29.

Wong, H. N. C., Hon, M. Y., Tse, C. W., et al. (1989). Use of cyclopropanes and their derivatives in organic synthesis. Chemistry Reviews, 89(1), 165198. 
Xie, M. W., Jin, F., Hwang, H., et al. (2005). Insights into tor function and rapamycin response: Chemical genomic profiling by using high-density cell array method. Proceedings of the National Academy of Sciences United States of America, 102(20), 7215-7220.

Yang, G. F., \& Huang, X. (2006). Development of quantitative structureactivity relationships and its application in rational drug design. Current Pharmaceutical Design, 12 (35), 4601-4611.

Young, J. D., Jarvis, S. M., Robins, M. J., et al. (1983). Photoaffinity labeling of the human erythrocyte nucleoside transporter by N6-(p-Azidobenzyl) adenosine and nitrobenzylthioinosine. Evidence that the transporter is a band 4.5 polypeptide. Journal of Biological Chemistry, 258(4), 2202-2208.

Zhao, J., Wei, S., Ma, X., et al. (2010). A simple and convenient method for the synthesis of pyranoid glycals. Carbohydrate research, 345(1), 168-171. 


\subsection{Appendix}

\begin{tabular}{|c|c|c|}
\hline \multicolumn{3}{|c|}{ Exclusion masses for MALDI TOF-TOF MS/MS } \\
\hline m/z monoisotopic & NAME & TOLERANCE $(\mathrm{m} / \mathrm{z})$ \\
\hline 659.384 & Trypsin & 0.03 \\
\hline 805.417 & Trypsin & 0.03 \\
\hline 861.060 & $\mathrm{CHCA}$ & 0.10 \\
\hline 877.000 & Polyethylene glycol & 0.10 \\
\hline 906.505 & Trypsin & 0.03 \\
\hline 1020.503 & Trypsin & 0.03 \\
\hline 1153.574 & Trypsin & 0.03 \\
\hline 1175.523 & Trypsin & 0.03 \\
\hline 1296.680 & Angiotensin 1 & 0.03 \\
\hline 1433.721 & Trypsin & 0.03 \\
\hline 1493.599 & Trypsin & 0.03 \\
\hline 1676.777 & Trypsin & 0.03 \\
\hline 1774.851 & Trypsin & 0.03 \\
\hline 2093.080 & ACTH (clip 1-17) & 0.03 \\
\hline 2163.057 & Trypsin & 0.03 \\
\hline 2193.003 & Trypsin & 0.03 \\
\hline 2193.995 & Trypsin & 0.03 \\
\hline 2273.160 & Trypsin & 0.03 \\
\hline 2289.155 & Trypsin & 0.03 \\
\hline 2305.150 & Trypsin & 0.03 \\
\hline 2465.190 & ACTH clip (18-39) & 0.03 \\
\hline 2514.339 & Trypsin & 0.03 \\
\hline 2550.233 & Trypsin & 0.03 \\
\hline 2612.181 & Trypsin & 0.03 \\
\hline 2613.350 & Trypsin & 0.03 \\
\hline 3211.475 & Trypsin & 0.03 \\
\hline 3227.400 & Trypsin & 0.03 \\
\hline
\end{tabular}




\begin{tabular}{|c|c|c|c|}
\hline $\mathrm{m} / \mathrm{z}$ monoisotopic & NAME & TYPE & CHARGE \\
\hline 904.468 & $\begin{array}{l}\text { des-Argl- } \\
\text { bradykinin }\end{array}$ & $r$ & +1 \\
\hline 1296.685 & Angiotensin & r & +1 \\
\hline 1570.677 & $\begin{array}{l}\text { Glu 1- } \\
\text { fibrinopeptide }\end{array}$ & r & +1 \\
\hline 2093.087 & ACTH (1-17) & $\mathrm{r}$ & +1 \\
\hline 2465.199 & ACTH (18-39) & r & +1 \\
\hline 3657.929 & ACTH (7-38) & $r$ & +1 \\
\hline
\end{tabular}

\begin{tabular}{|c|c|c|c|}
\hline m/z monoisotopic & NAME & TYPE & CHARGE \\
\hline 255.1090 & $\begin{array}{l}\text { B2-17(-NH3) } \\
\text { fragment ion }\end{array}$ & $r$ & +1 \\
\hline 354.1780 & $\begin{array}{l}\text { B3-17(-NH3) } \\
\text { fragment ion }\end{array}$ & $r$ & +1 \\
\hline 784.4110 & B6 fragment ion & $r$ & +1 \\
\hline 1181.6580 & $\begin{array}{l}\text { Angiotensin } \\
\text { fragment ion }\end{array}$ & $r$ & +1 \\
\hline 1183.6010 & $\begin{array}{l}\text { Angiotensin } \\
\text { fragment ion }\end{array}$ & $r$ & +1 \\
\hline
\end{tabular}




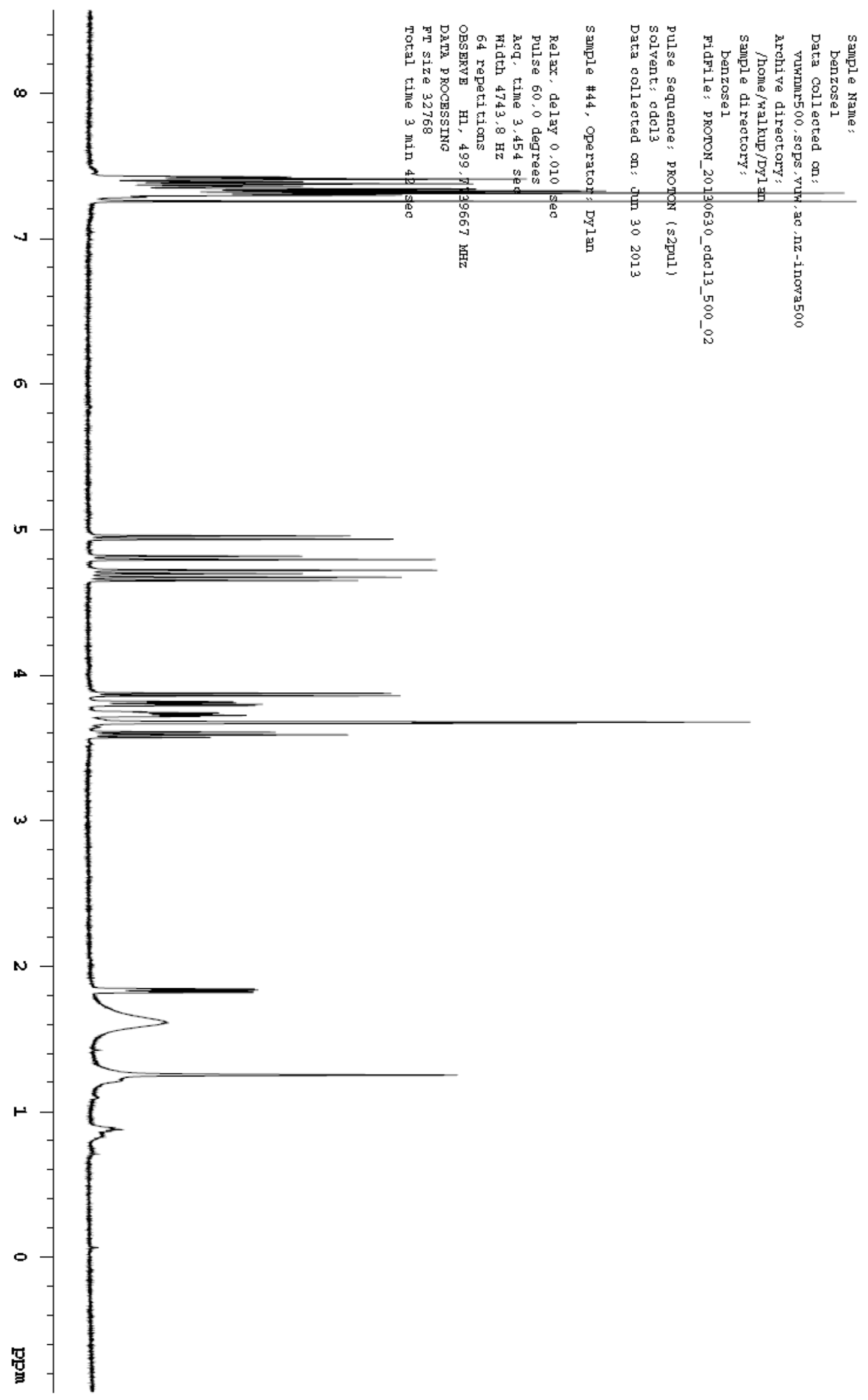




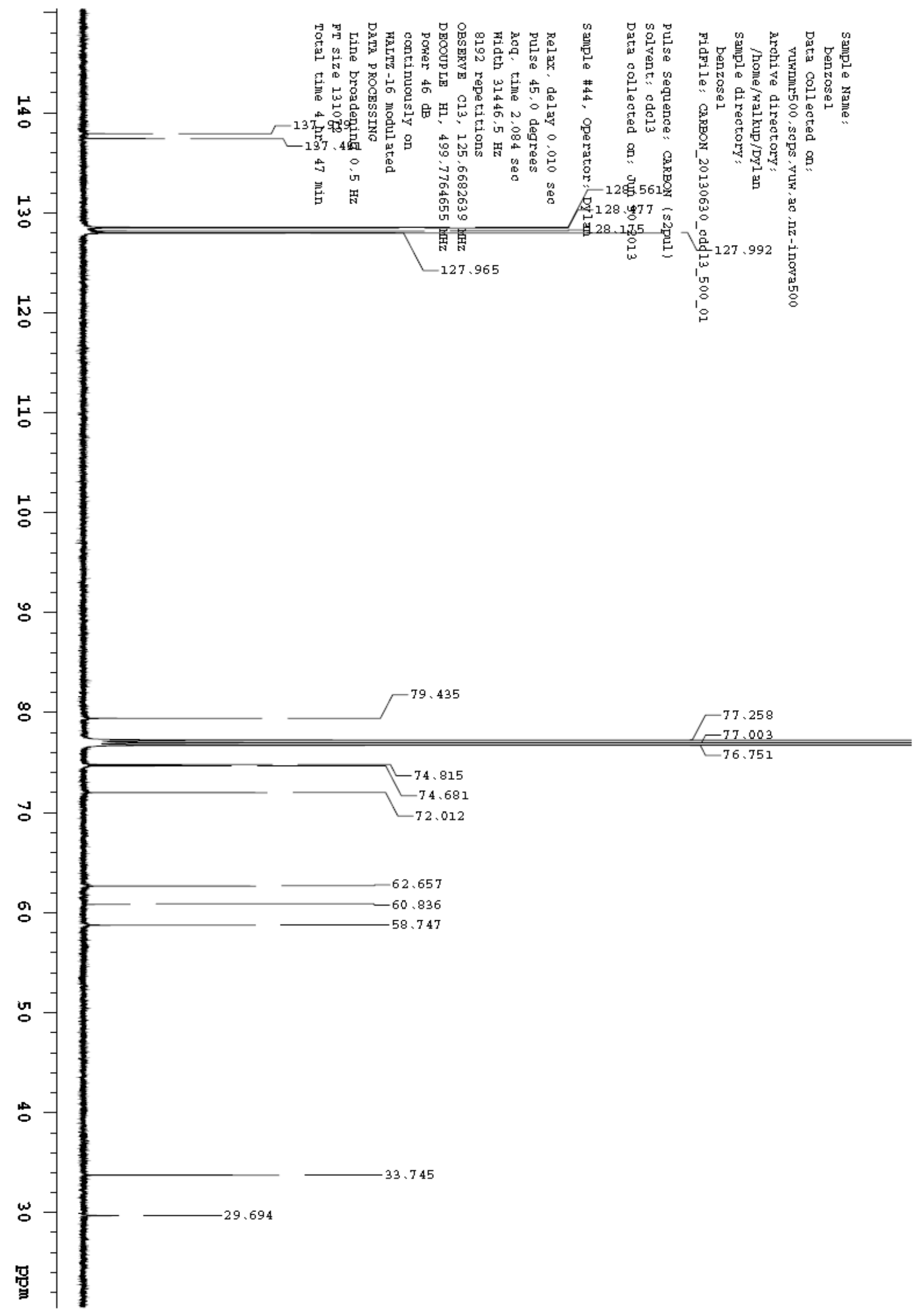




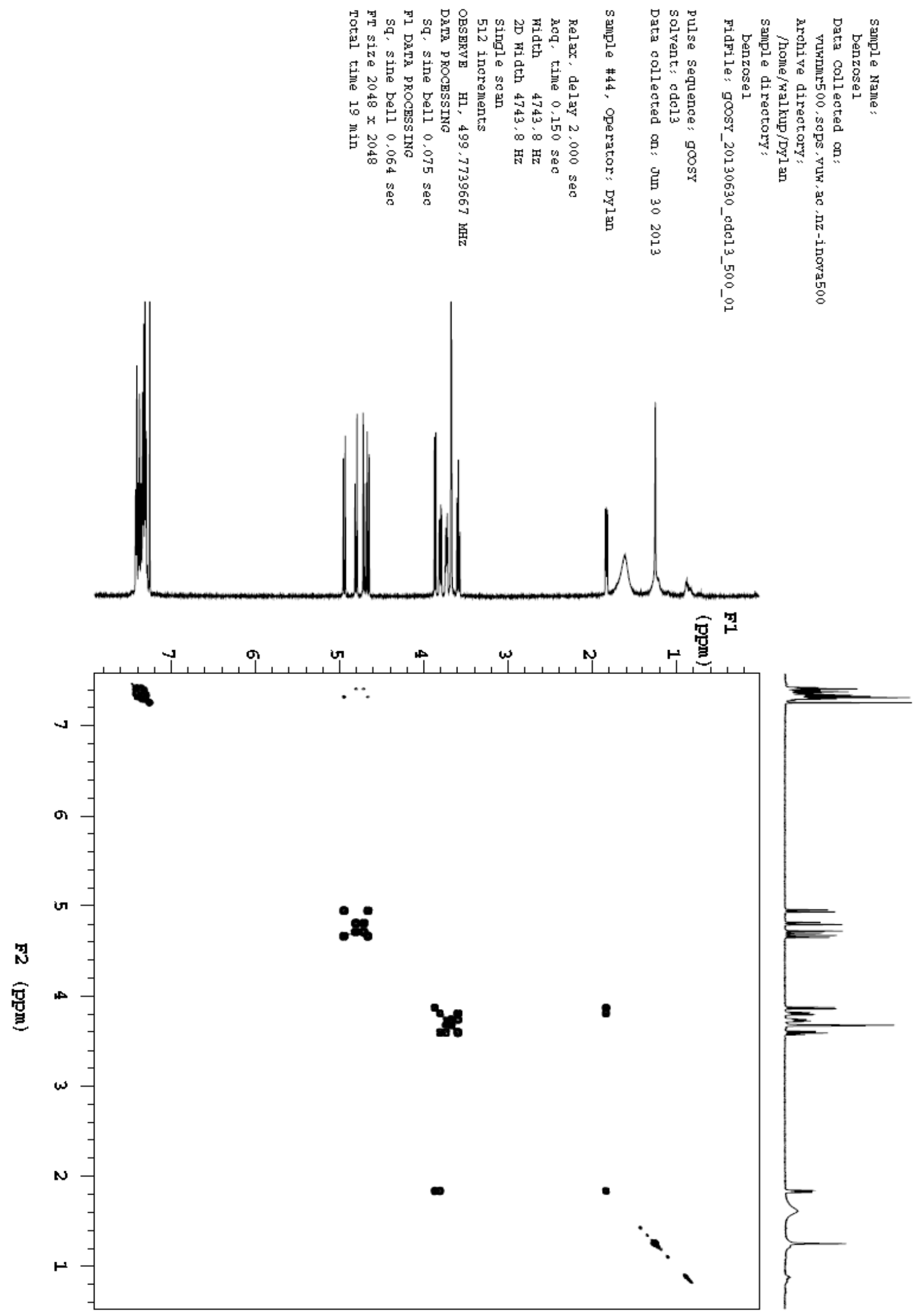




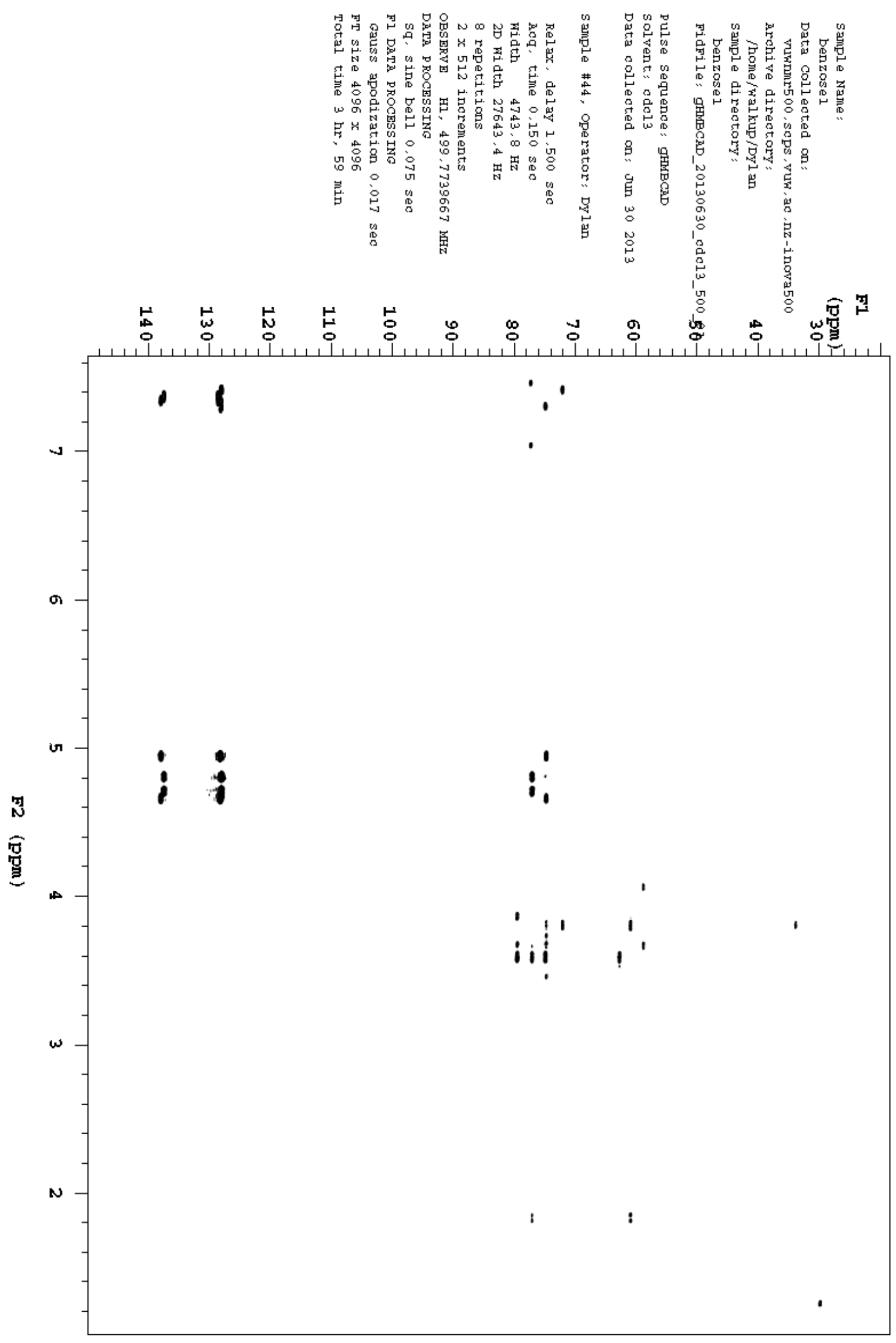




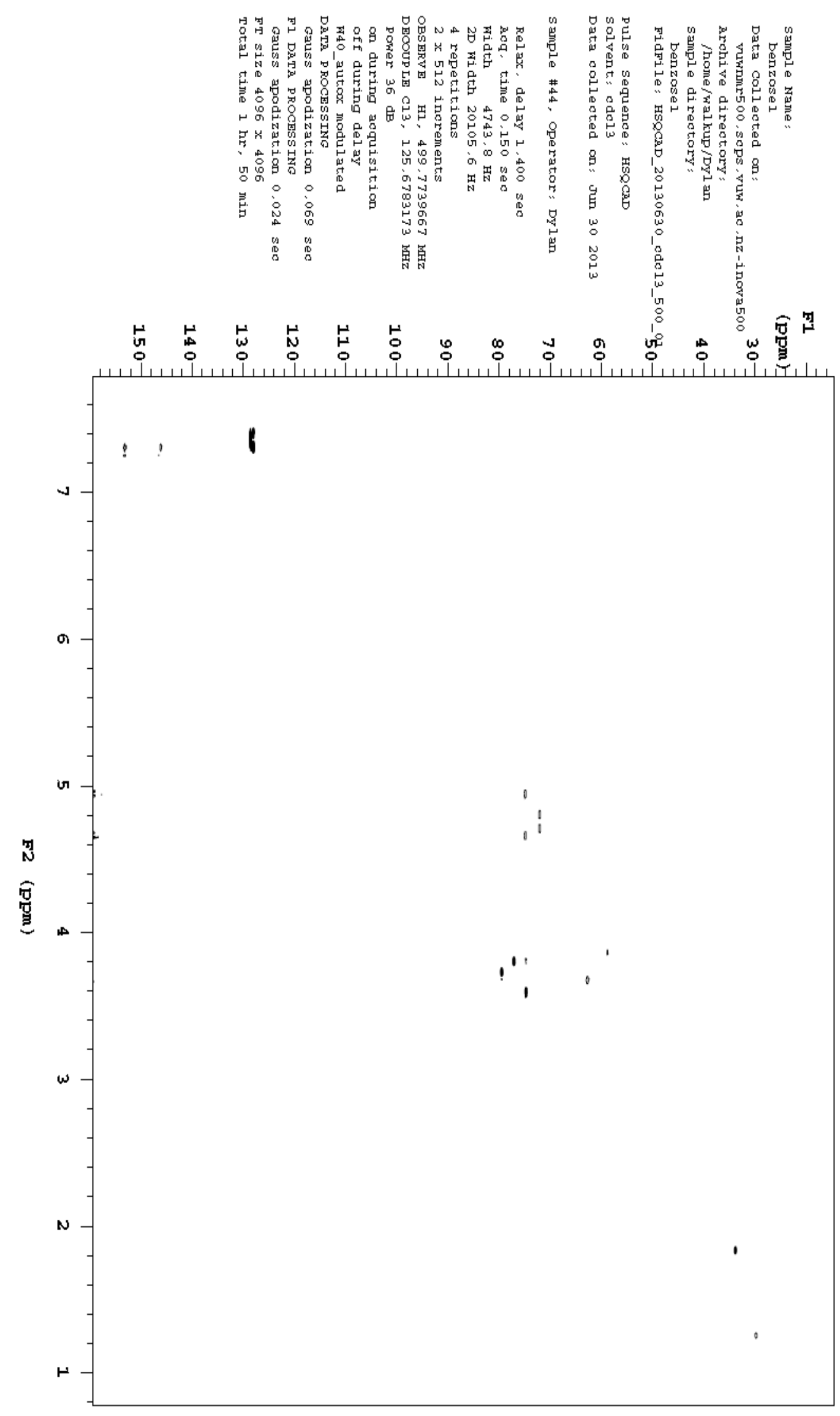




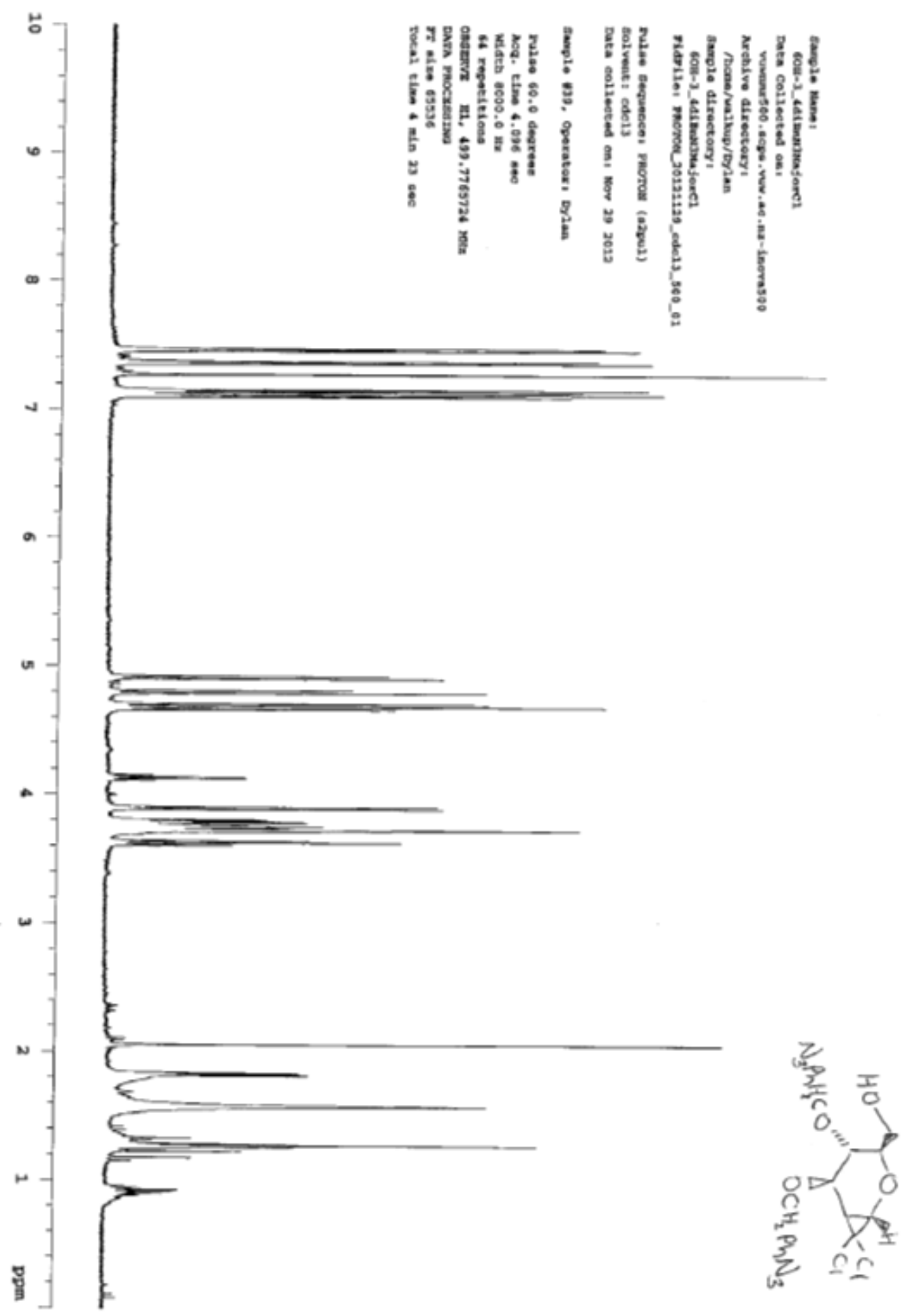




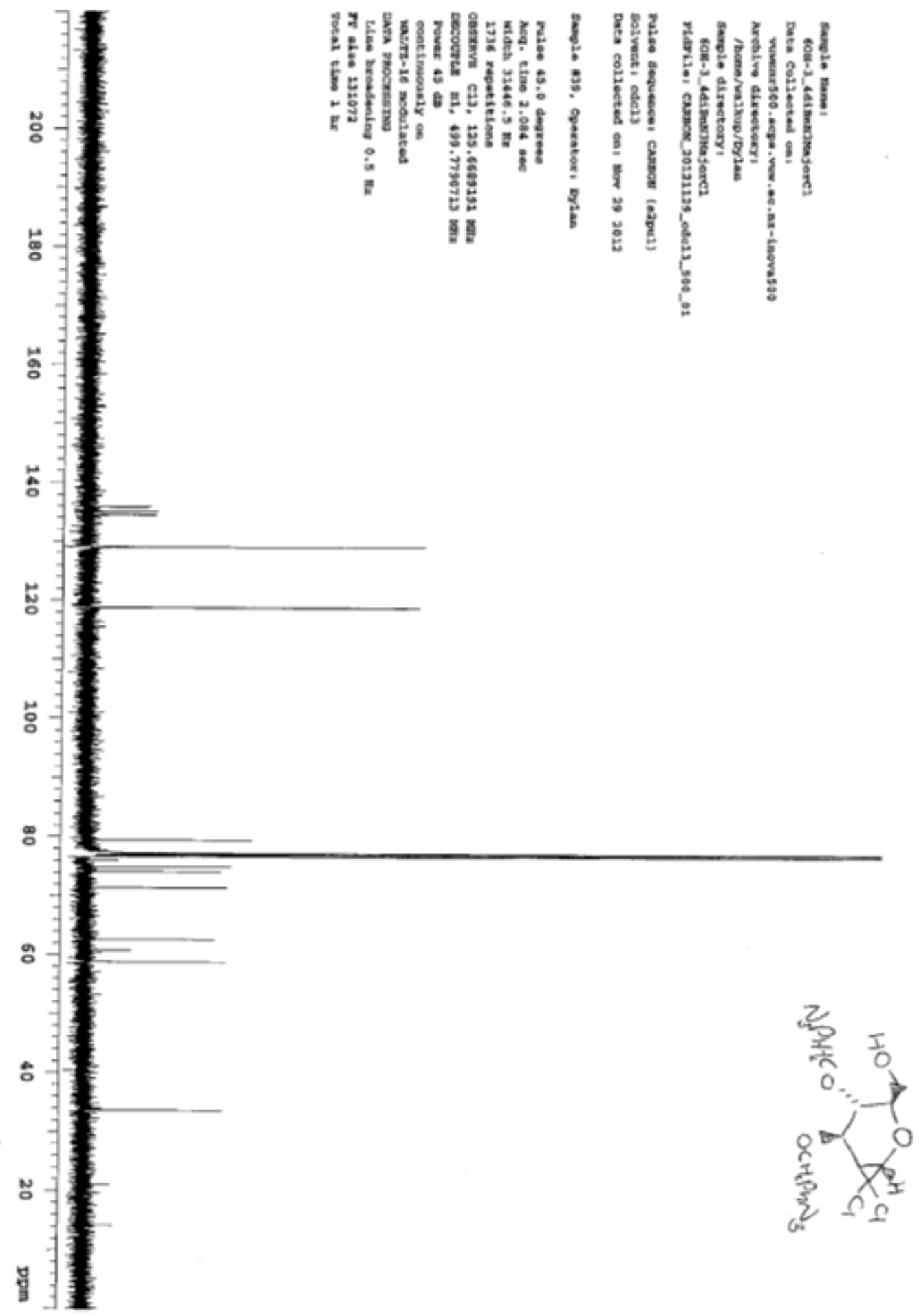




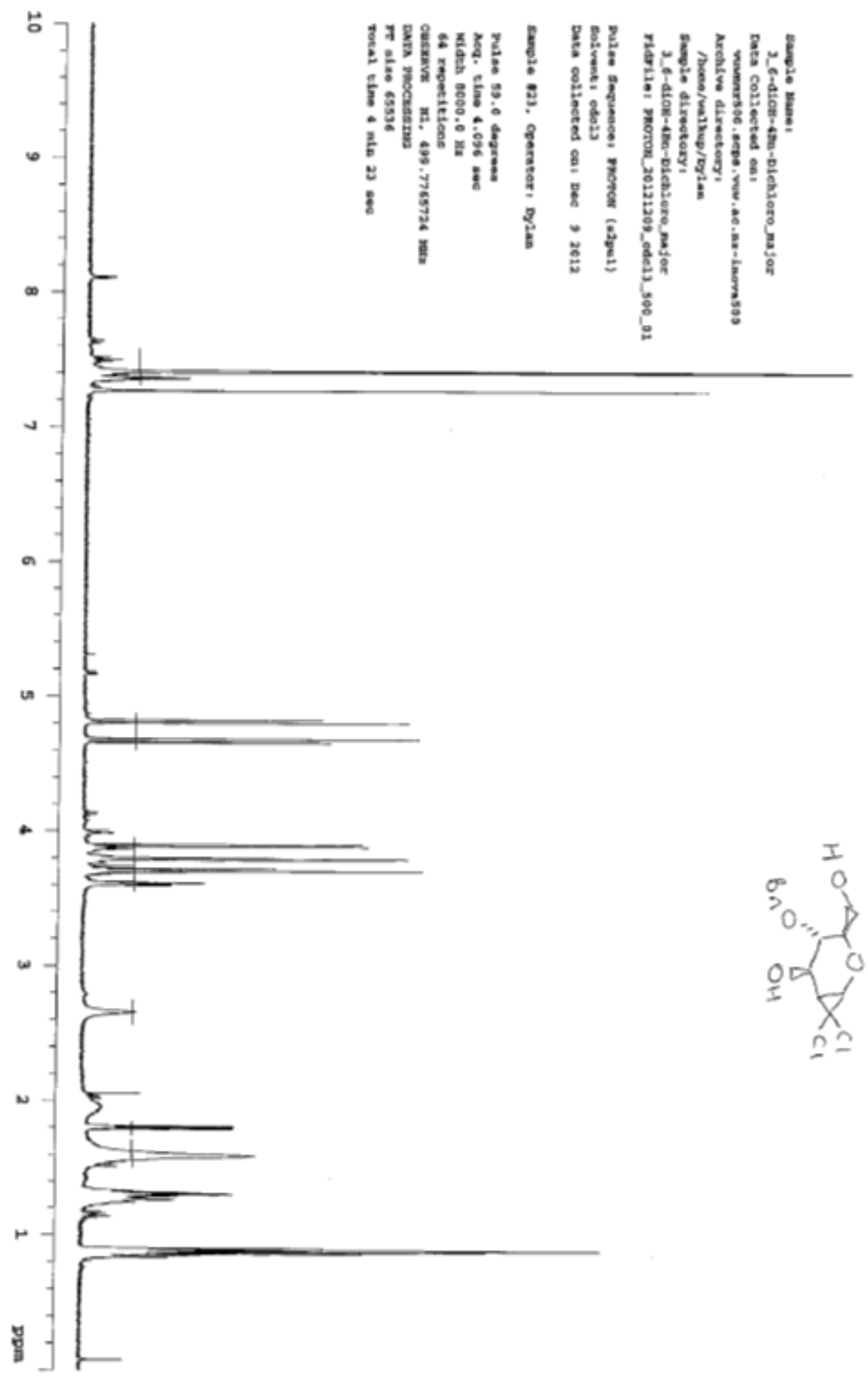




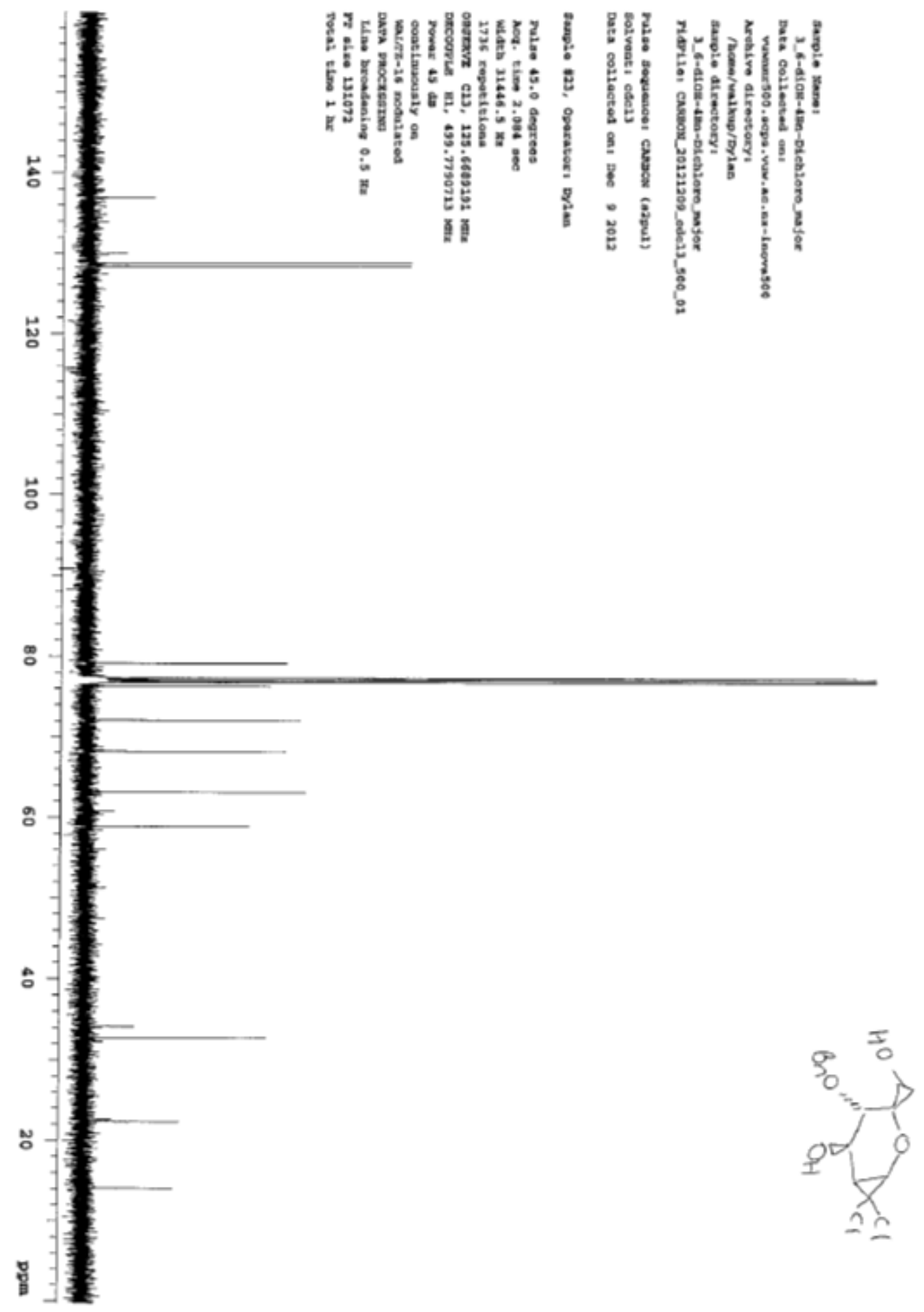




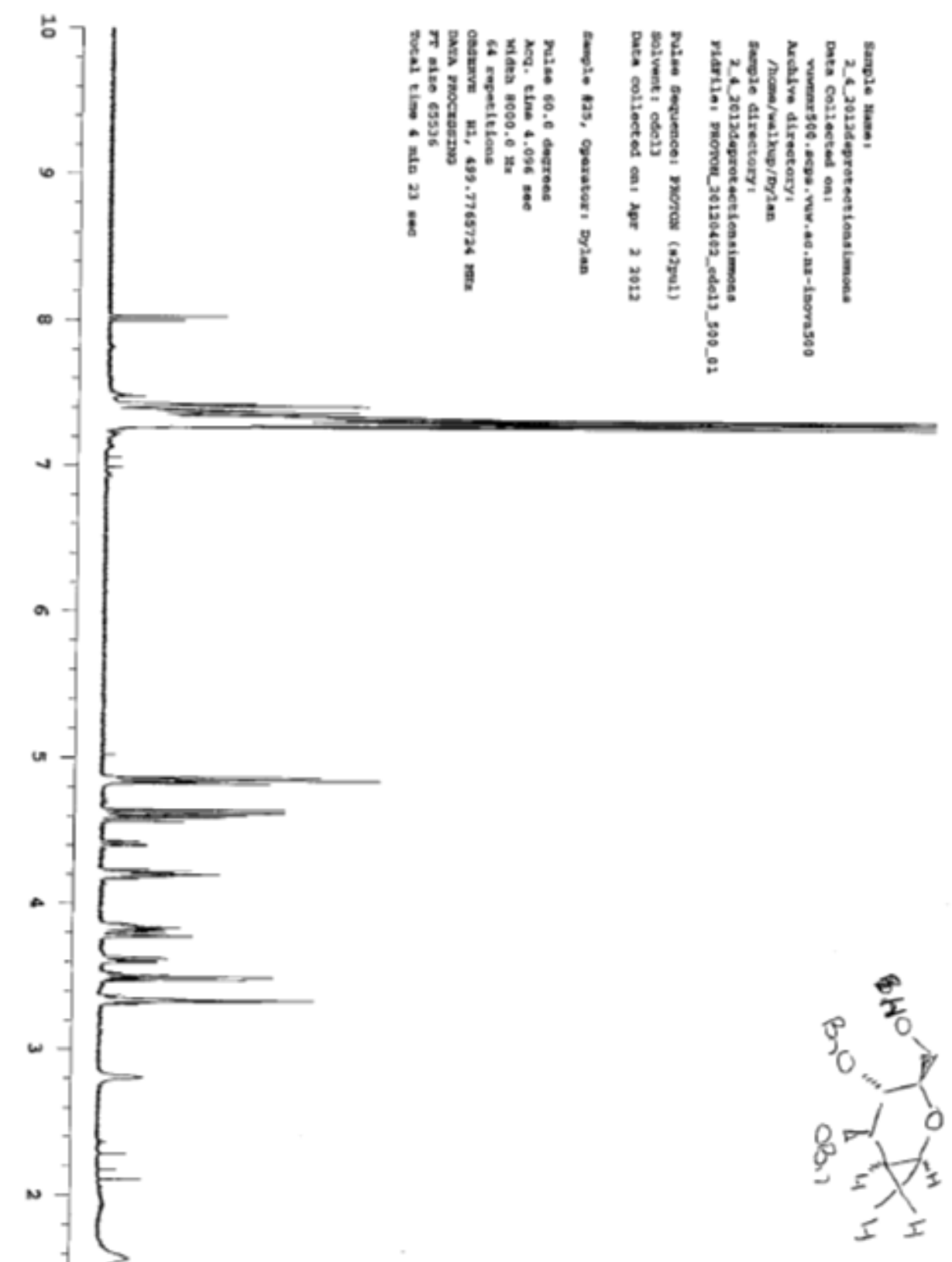

162 | P a g e 


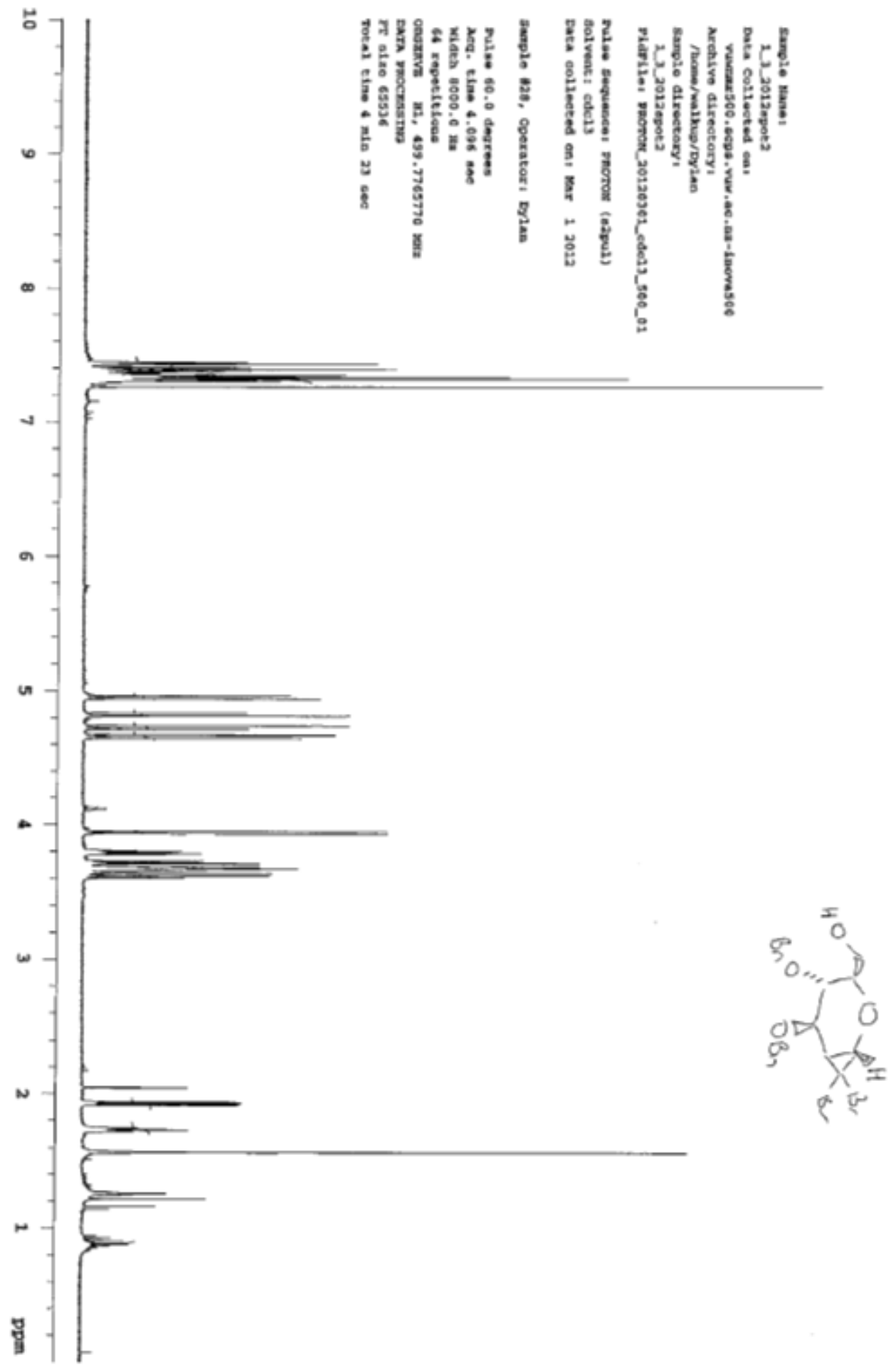




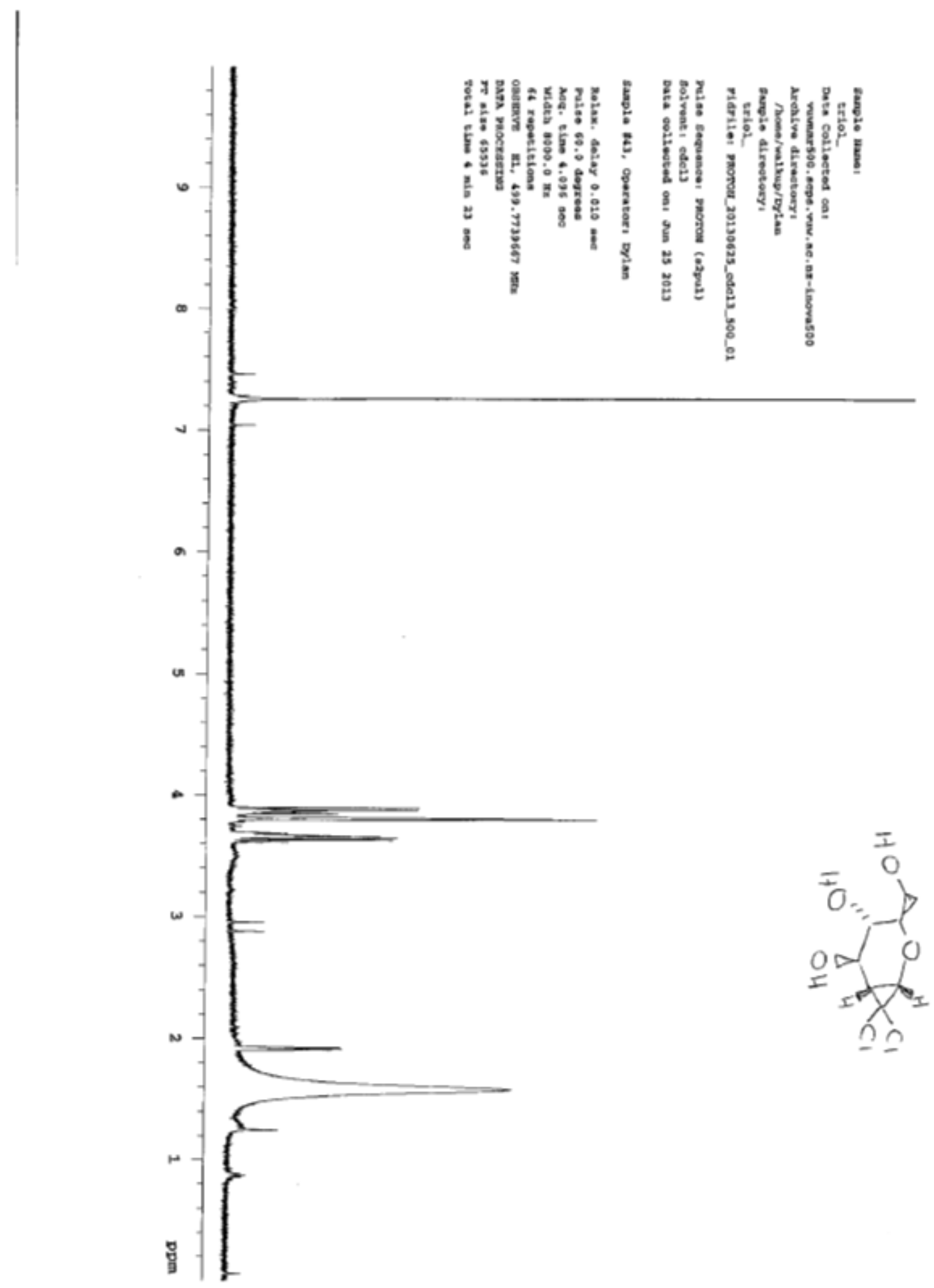

164 | P a g e 


\section{Extra bit}

\section{Acknowledgements}

A Masters project is a journey like that taken by Captain Jean-Luk Picard and the crew of the star ship Enterprise. My self as the captain, my supervisors Paul and Joanne as the admirals, and all those in my labs as the crew of my Enterprise without one there would have been holes in the smooth running of the ship, as with my thesis. Paul played the most important role as the Rear Admiral Quinn but rather than having neural parasites, Paul only had a vast amount of time and knowledge to share, to help me develop my skills at avoiding disastors on board my ship. Joanne played a curial role in my battle plans, organisation of the starships Yamaguchi, Bellerophon and Saratoga, we managed to overcome the Borg, one of the greater challenges I faced. We lost the Battle of Wolf but we won in the end. Christina (William Riker) my first officer, influenced many of my choices, not that I listened to all of them, but it helped my to a great deal, together with Peter (Worf) I was able to achieve much more than I expected to achieve in my two years with the Star fleet. Fighting Klingons and Romulans it was not always fun but as a crew we managed to triumph.

I would also like to acknowledge Captain Jean-Luk Picard, Captain Jonathon Archer, and Captain James T. Kirk for providing entertainment on those long nights doing 130 fraction columns and taking photos in the early hours of the morning. 